HEALTH, MEDICINE, AND SCIENCE IN ASIA

Edited by Anoma P. van der Veere, Florian Schneider, and Catherine Yuk-ping Lo

\title{
Public Health in Asia during the COVID-19 Pandemic
}

Global Health Governance,

Migrant Labour, and International Health Crises 
Public Health in Asia during the COVID-19 Pandemic 


\section{Health, Medicine, and Science in Asia}

Over the last few decades, the Asian health landscape has gone through profound and dramatic changes. While access to healthcare shows severe inequalities from one country to the other and within countries, the region as a whole has positioned itself as a world player in the domain of health. Asia has become one of the primary destinations for medical and wellness travelers, attracted by specialized hospitals that follow international standards and provide first class treatments. The Asian pharmaceutical sector is a global competitor and therapeutic innovation is fueling new domestic healthcare markets. Biotech and clinical research are often equivalent to that seen in Europe and North America, while Asian traditional medicines have become a central feature of most contemporary societies, with a significant proportion of their industrial production aimed at export. New forms of therapeutic practices, knowledge and objects have emerged from the encounter of Asian medicine and biomedical science, giving way to braided concepts, products and tools, new epistemologies and understandings of the body, or again, revised regulatory schemes. Asian-born pandemics have contributed to redefine global health procedures, principles and meaning. The parallel evolution of these sectors coupled with structural transformations and new health policies, technological advancement and a low-cost workforce, have largely contributed to the renewal of Asian health services. This has not only modified national health policies and initiatives but also contributed to transforming the image of Asia in the realm of science and medicine. This book series seeks to bring attention to two decisive phenomena in these processes. The first concerns the uneasy relationship between increasing social disparities, the market and structural and technological developments in the field of health. The second phenomenon deals with global issues and their scales, as macro dynamics, transnationalism and local forms of globalization impact the production of health. This dual approach, embedded into the politics of healing, such as modes of governance and regulation, will help to explore the local fabric and global aspirations of Asian health. Studies from a variety of disciplines, from history to anthropology and the social study of science provide the backbone of the series.

\section{Series editor}

Laurent Pordié, National Center for Scientific Research (CNRS), Paris

\section{Editorial board}

Sienna Craig, Dartmouth College

Wen-Hua Kuo, National Yang-Ming University, Taipei

Alex McKay, International Institute of Asian Studies, Leiden

Projit Bihari Mukharji, University of Pennsylvania

Volker Scheid, University of Westminster, London 


\title{
Public Health in Asia during the COVID-19 Pandemic
}

Global Health Governance, Migrant Labour, and International Health Crises

\author{
Edited by \\ Anoma P. van der Veere, \\ Florian Schneider, and \\ Catherine Yuk-ping Lo
}


Cover image: with permission from Nick Potts

Cover design: Coördesign, Leiden

Lay-out: Crius Group, Hulshout

$\begin{array}{ll}\text { ISBN } & 9789463720977 \\ \text { e-ISBN } & 9789048555^{24} 6 \text { (pdf) } \\ \text { DOI } & 10.5117 / 9789463720977 \\ \text { NUR } & 870\end{array}$

(c) The authors / Amsterdam University Press B.V., Amsterdam 2022

All rights reserved. Without limiting the rights under copyright reserved above, no part of this book may be reproduced, stored in or introduced into a retrieval system, or transmitted, in any form or by any means (electronic, mechanical, photocopying, recording or otherwise) without the written permission of both the copyright owner and the author of the book.

Every effort has been made to obtain permission to use all copyrighted illustrations reproduced in this book. Nonetheless, whosoever believes to have rights to this material is advised to contact the publisher. 


\section{Table of Contents}

Introduction: COVID-19 and Asia

Anoma Phichai VAN DER VEERE, Florian SCHNEIDER, and

Catherine Yuk-ping LO

\section{PART I Health Policy in Asia and the Global Community}

1 Fighting for a Global Community in a Post-COVID World

Haruko SATOH

2 Countering Emerging Infectious Diseases and COVID-19

The Development of ASEAN's Institutional Arrangements and International Cooperation

Kei KOGA

3 The Outbreak of Infectious Disease and Trust in Government in Asian Countries

Yumi ISHIKAWA and Miki KOHARA

\section{PART II The Future of Global Health Governance in Asia}

4 China and the World Health Organization

Not an Easy Road for Either

Xue GONG and Xirui LI

5 South Korea and the WHO during the COVID-19 Crisis

Brendan HOWE

6 Escaping the 'Realist Trap'

The ROC's Participation in Global Health Governance Under the One-China Principle

Catherine Yuk-ping LO 
7 From Pneumonia to Pragmatism

The Role of the WHO in Japan During Public Health Emergencies

Anoma P. VAN DER VEERE

\section{PART III Domestic Responses to COVID-19 in a Globalized Asia}

8 The COVID-19 Pandemic

Socio-Economic Issues, Health Care, Health Security and the Rapid

Response in Vietnam

Anh Tuyet NGUYEN

9 The Coordination of COVID-19 Responses in Malaysia

Efforts and Challenges

Nurliana KAMARUDDIN and Zokhri IDRIS

10 Analysis of South Korea's Experience with the COVID-19

Pandemic and its Relations with the WHO

Eun Mee KIM and Jisun SONG

11 State-Society Relations as Cooperative Partnership and the

COVID-19 Response in Vietnam

Mirjam LE and Franziska NICOLAISEN

\section{PART IV The Global Economy and Transnational Migrant Labour in Asia during COVID-19}

12 The Coronavirus as the 'Final Straw' of the CCP's Performative Legitimacy?

A New Economic Model in the Post-COVID-19 Era

Catherine Yuk-ping LO

13 Health Governance during the COVID-19 Pandemic

Reflections on Taiwan's Guest Worker Policy

Mei-Chun LIU 
14 Public Health and Capitalism in Japan

The Impact of Labour Market Challenges and Welfare on Public Health

Saori SHIBATA

15 Indonesia's Response to Global Recommendations on Labour 259 Migration during a Pandemic: Muddling through Priorities and Needs

Sylvia YAZID

\section{List of Figures and Tables}

\section{Figures}

Figure 3.1 Average level of trust in sample governments

Figure 3.2 Average level of trust in the SARS-affected (treatment) and non-affected (control) groups

Figure 4.1 Number of Statements Submitted to the WHA by China, the EU, and the US

Figure 4.2 WHO Assessed Contributions by Countries (Updated until Q2 2020)

Figure 4.3 WHO Specified Voluntary Funding by Parties (Updated until Q2 2020)

Figure 4.4 WHO Projected Funding by Parties (Updated until Q2 2020)

Figure 4.5 WHO Collaborating Centres in the US and China by Subjects (Pending and Active)

Figure 8.1 The Number of Confirmed and Daily New Confirmed COVID-19 Cases in Vietnam

Figure 10.1 South Korea's ODA Trend for 2015-2021

\section{Tables}

Table 3.1 Socio-Demographics, SARS Epidemiological Data, and the Responses of Governments and the WHO in Target Regions

Table 8.1 A summary timeline of nationally implemented policies in Vietnam and the WHO's recommendation and response plan

Table 9.1 Daily reported cases from 25 September to 12 October 2020 
Table 10.1 South Korea's Contributions to the Global Health Initiatives 181

Table 10.2 Global Solidarity Groups on COVID-19 Launched by South Korea 183

Table 10.3 Editorials on the WHO in South Korean Media 185

Table 10.4 Remarks from President Moon, Jae-in on the WHO 190 


\title{
Introduction: COVID-19 and Asia
}

\author{
Anoma Phichai VAN DER VEERE, Florian SCHNEIDER, and \\ Catherine Yuk-ping LO
}

Keywords: global health governance, labour migration, Asia, public health, COVID-19, globalisation

In late 2019, the world watched closely as cases of an unknown virus causing pneumonia started spreading through Wuhan province in the People's Republic of China (PRC). Gradually, more cases were being reported, and on Saturday 11 January 2020 Chinese state media announced the first fatality (Qin and Hernández 2020). While the virus, now more commonly known as COVID-19, spread across the globe with unprecedented ease, it would take the World Health Organization (WHO) until 30 January to declare the outbreak a public health emergency of international concern (PHEIC). ${ }^{1}$ By this time, there had been 7834 confirmed cases and 170 people had lost their lives to the virus (WHO 2020a).

With the benefit of hindsight, we can now see that the virus has wreaked havoc on the world. By 30 January 2021, a year after the PHEIC announcement, almost every country and region had been hit (WHO 2021a). Over 100 million people had been infected, resulting in more than two million deaths. The interconnectedness of our modern transport systems carried people from Wuhan to ports on every continent before any viable measures were put in place, spreading the virus every where. As the outbreak developed, it was those nations that are geographically close to China, in East Asia and Southeast Asia, that especially struggled to cope with its scale. Different

\footnotetext{
1 A PHEIC is defined as 'an extraordinary event which is determined to constitute a public health risk to other states through the international spread of disease and to potentially require a coordinated international response'. This definition implies a situation that: 1 ) is serious, sudden, unusual or unexpected; 2) carries implications for public health beyond the affected state's national border; and 3) may require immediate international action (WHO 2008, 19).
}

\footnotetext{
Van der Veere, Anoma P., Florian Schneider, and Catherine Yuk-ping Lo (eds), Public Health in Asia during the COVID-19 Pandemic: Global Health Governance, Migrant Labour, and International Health Crises. Amsterdam, Amsterdam University Press 2022 DOI: 10.5117/9789463720977_INTRO
} 
conditions have led to different results in these countries. South Korea and Vietnam, for instance, had previously experienced the dangers of public health crises during the SARS epidemic in the early 200os, and as a result they were well-equipped to deal with the virus (see in this volume: Le \& Nicolaisen, and Nguyen for Vietnam; Howe, and Kim \& Song for South Korea). Similarly, Taiwan (ROC) was able to quickly respond to the outbreak (see Lo, and Liu), despite its connections to the PRC. However, countries like Indonesia and Japan were less prepared (see Yazid, Shibata, and Van der Veere). Meanwhile, Malaysia was suffering an acrimonious political shift that resulted in a delayed response to the developing public health threat (see Kamaruddin \& Idris).

These examples show that talking about Asia is challenging. It is the largest region on the planet, containing dozens of political systems, thousands of languages and cultures, and billions of people. Moreover, as area studies scholars have repeatedly pointed out, any attempt at defining it has political implications, making it a difficult concept to work with (see for example the contributions in Wesley-Smith and Goss 2010). Despite this theoretical ambiguity, however, the term 'Asia' has real-world uses. When we visit the websites of some of the world's largest media outlets, news from the region is frequently sorted under the banner 'Asia'. Our understanding is therefore partly formed by our consumption of the concept of 'Asia', ambiguous as it may be. ${ }^{2}$ This ambiguity offers some disadvantages, especially in a scholarly work such as this one. However, it offers one benefit. The main reason that we have chosen to use Asia in the title of the book is because of the diversity of the region. Leaning into the ambiguities that come with attempts to define the region allows us to offer contrasting and comparative perspectives that might enable a better understanding of how dynamic a region like Asia is, and why public health crises such as the COVID-19 pandemic develop in different ways even within such a region.

This book reflects this diversity by including chapters that respectively focus on different countries, regions, governments, and institutions. It offers local perspectives, local knowledge, and new information in an accessible and informative way. One of the main motivations for creating this volume has been to provide policy makers and health specialists with a better picture of the different strategies that have been employed in Asia

2 See for example BBC News, https://www.bbc.com/news/world/asia; or CNN, https://edition. cnn.com/asia. Even media outlets based in Asian countries often default to the 'Asia' category, see for example Nikkei Asia, https://asia.nikkei.com/; and the South China Morning Post, https:// www.scmp.com/news/asia. 
during the COVID-19 pandemic. It does this using thoroughly researched and informed case-studies that are presented in an accessible format. Although every country has its own context, and every institution operates in its own place and time, hopefully this volume will deepen our shared understanding of how interconnected people and institutions interact during times of crisis.

\section{The Importance of Understanding COVID-19 and Asia}

In 2019, the Nuclear Threat Initiative and the Johns Hopkins Center for Health Security published a report titled the 'Global Health Security Index' (2019). In its conclusions, the report judged countries like the United States, the United Kingdom, the Netherlands, and Brazil as being 'Most Prepared'. This was ostensibly for their ability to rapidly respond to the spread of an epidemic. The only two Asian countries deemed 'Most Prepared' were South Korea and Thailand. This was only a few months before the COVID-19 pandemic would devastate the global economy and throw international mobility into disarray. The COVID-19 pandemic, which is currently far from over, has already cost millions of lives and has shown that the list in this report was shockingly off the mark.

The supposed preparedness of different countries presented in this report is jarring considering the disorienting conditions into which the world was plunged as the pandemic spread. The constantly changing nature of the pandemic has left most observers guessing what was working well, and what was not. This has led to a wave of erroneous, often hastily constructed interpretations that have found their way into daily lived experiences. Japan is an excellent case in point. The country's government was slow to act when it was forced to deal with a cruise ship full of infected tourists in February and March 2020, early on in the pandemic. Through its ineffective handling of the situation, the government inadvertently created a cruise ship-sized COVID-19 petri-dish on the shore of Yokohama, near one of the world's most densely populated metropolitan areas. It was widely lambasted for this failure to act in the media and by other governments and institutions (Ratcliffe and Fonbuena 2020). Only two months later, however, with the number of infections stabilizing in the country but exploding abroad, the Director-General of the WHO praised Japan's approach, hailing it as a great success (Kyodo News 2020). This cycle of ascribing either failure or success, depending on the circumstances of the moment, has continued ever since. 
There has been a tendency in media reports to arrive at hasty conclusions based on circumstantial evidence. This has in turn resulted in a high level of mixed messaging. However, it would be irresponsible to lay the blame solely with the media. Government officials, policy makers, and global actors have taken part in the same game. As a consequence, such inaccuracies have also found their way into official policymaking.

One example is an international comparative country review produced by the Dutch Ministry of Labour, Welfare and Sports. This report was written to inform the Dutch government about varying approaches to maintaining public health during the COVID-19 pandemic. The two health policy specialists who authored the report found it helpful for their understanding of Asia to include South Korea as a case-study. They employed the Hofstede model of national culture to frame their understanding of South Korea and indirectly the 'Asian approach'. Despite the wide-spread criticisms of the Hofstede model, it continues to be used as if it reliably represents factual and objective scientific analysis. It is beyond the scope of this volume to delve into the many problems with the model, ${ }^{3}$ but it is helpful to quote a particular section from the aforementioned report in order to illustrate how this model is used to make problematic arguments about the success of the South Korean public health model:

\begin{abstract}
A large difference becomes clear from the observation that South Korean society is a lot more collectivist. [...]. ${ }^{4}$ Moreover, as South Korean society is primarily feminine this leads to most people realizing that everyone is part of a group or that their role is to protect vulnerable people. [...]. To conclude, South Koreans are less abundant than Dutch people. This makes it easier for them to follow measures that restrict freedom for longer periods of time (Hagenaars and Jeurissen 2020, 12). ${ }^{5}$
\end{abstract}

3 The Hofstede model is by and large a collection of statistical information based on fallacious assumptions, yet it has remained popular as a measure for 'national cultures'. We agree here with Brendan McSweeney's description of the model as methodologically flawed and 'a restrictor not an enhancer of understanding particularities' (2002, 112). McSweeney also states that 'the identification claims are fundamentally flawed and the attribution of national level actions/ institutions to national cultures is an easy but impoverishing move'.

4 The part left out of the quotation above reads: 'And where the Netherlands is slightly risk averse and pragmatic, South Korea is very risk averse and extremely pragmatic. Both of these issues contribute to a culture that is able to change gears quickly and powerfully when necessary in the face of an emerging infectious disease.'

5 Author translation. For readers wondering if a translation of the complete section will add relevant context that will lead to the salvation of the report's conclusions, I can assure you none exists. 
All of the above statements can be disproven point by point. More importantly, the authors have chosen to eschew a thorough analysis that critically analyses domestic measures in the context of a more successful approach. Instead, they present their findings in a way that serves to justify their own set of (ineffective) public health measures - and even the hesitancy to implement such measures - in the context of the Netherlands. The conclusion ignores any political factors that may have caused Dutch people to be more hesitant towards public health measures. It also does not address the possible causes of civil compliance among South Koreans, such as previous experience with public health crises, national interests, or the evolution of transnational political discourses on public health. Instead, the population is deemed collectivist, feminine, and less abundant.

Interestingly, an early survey study showed that in countries including the Netherlands 'public belief in the effectiveness and the actual implementation of certain protective measures during the early phase of the COVID-19 pandemic in March 2020 was high' (Meier, et al. 2020). The decline in social compliance of Dutch people in the later months of the pandemic can therefore be better attributed to a set of obviated domestic circumstances that the authors of this report fail to address. Given this missed opportunity, or possibly in spite of it, the authors attempt to explain away public resistance in the Netherlands through naturalistic comparisons with the South Korean population. Their report is an excellent example of how actors outside of Asia frequently misunderstand, or even wilfully misrepresent, the politics and cultures of the region. Such actors use the regrettably widespread public ignorance regarding Asia to dismiss governance approaches that clash with entrenched habits and ideologies.

Of course, not all policy-makers dismiss Asia as callously as the authors of this Dutch policy report; many are aware that there are lessons to be learned. There is then a serious need for informed case studies that highlight the most important issues in an accessible, concise manner. This book seeks to do this. For example, it covers the South Korean case in two chapters. The first of these details and contextualizes the South Korean government's national interests within a framework of global health governance (Howe). The second chapter then explains how official and public sentiments have affected South Korea's relations with the WHO (Kim \& Song). These and other case studies in this volume offer a wealth of in-depth information about how different governments, organizations, and political actors across the Asian region have handled COVID-19. 


\section{Global Health Governance and Asia}

Under the strain of our world's ever increasing interconnectedness, the global system of health governance currently in place has come under increasing pressure. As the largest health institution in the world, the WHO's role in responding to the COVID-19 pandemic has been widely criticized for being slow and inefficient, and even for ostensibly appeasing China, where the virus originated. While governments were scrambling to respond to the emerging threat of COVID-19, the pandemic became increasingly politicized. Over the course of the pandemic, the line between public health concerns and political contestation has been blurred and the effects of already existing international political tensions have been magnified. An example of this was China's so-called 'mask diplomacy', where it sought to win the favour of other countries through the supply of masks and medical equipment (see Satoh). Another example is the high-profile political debates about the exact origins of the virus that have occurred in several different countries, particularly in the US.

The health-politics nexus is further demonstrated in the case of the WHO's declaration of a PHEIC. The WHO has had the responsibility for determining when an outbreak is a global public-health emergency since 2005. However, it has only done this five times prior to the COVID-19 pandemic: during the swine-flu pandemic in 2009; the Ebola outbreaks in West Africa in 2014 and in Congo in 2019; the emergence of polio in war zones in 2014; and the Zika epidemic in 2016. The amount of time it has taken for the WHO to declare a particular situation a PHEIC has nevertheless been a focal point of criticism. For instance, during the $2009 \mathrm{H}_{1} \mathrm{~N}_{1}$ outbreak, it took the $\mathrm{WHO}_{3} 8$ days to declare a PHEIC after laboratories isolated HiN1 on 18 March 2009. In sharp contrast to the speed of global action regarding $\mathrm{H}_{1} \mathrm{~N} 1$, a PHEIC was not declared until 138 days after the first detected case of Ebola in West Africa on 22 March 2014 (Hoffman and Silverberg 2018, 330). ${ }^{6}$

The reason why the WHO declares, or does not declare, a particular situation as a PHEIC has been another point of criticism. Critics have argued that the WHO's decision is based on the economic conditions of the affected countries. The Ebola outbreak in 2014 is a case in point. A leaked document shows that the WHO intentionally delayed declaring a PHEIC for the sake of avoiding catastrophic economic consequences for Guinea and other afflicted

6 The H1N1 outbreak began on 15 March 2009, was detected on 18 March 2009, and was declared a PHEIC on 25 April 2009. The West African Ebola outbreak began on 26 December 2013, was detected on 22 March 2014, and was declared a PHEIC on 8 August 2014. 
countries (Boseley 2015). A study conducted by Hoffman and Silverberg (2018, 331) indicates that the direct impact of infectious diseases on the US is also a necessary condition for a global health emergency pronouncement. A PHEIC was declared ten days after the first US citizen was detected with the $\mathrm{H}_{1} \mathrm{~N}_{1}$ infection. Meanwhile, Ebola was declared a PHEIC just six days after infected health care providers arrived in the US for treatment on 2 August 2014.

When COVID-19 hit at the start of 2020, the WHO was blamed for serving the interests of the Chinese government. Social media users have mocked the WHO as 'Winnie the Pooh Health Organization', referencing the common practice among Chinese Internet users of comparing Chinese President Xi to Winnie the Pooh (McDonnell 2017). Others have referred to the $\mathrm{WHO}$ as $\mathrm{CHO}$ (Chinese Health Organization) to express their anger about the way that the WHO is supposedly managing the pandemic in line with Chinese interests (see Van der Veere). The US and countries in Europe have condemned the WHO for being vulnerable to Chinese influence. This susceptibility is exemplified in the eyes of critics by the fact that Taiwan, also called the Republic of China (ROC), has not been invited to attend the World Health Assembly (WHA), the highest decision-making body within the WHO, since 2017 (see Lo).

In the process, the legitimacy of the WHO has gradually been eroded. Although we can attribute a certain degree of this erosion to global perceptions of its response, we also need to understand the current state of the organization and the way it functions. Established in 1948 as a specialized agency of the United Nations (UN), the WHO is currently the most comprehensive global health organization, tasked with preventing the global spread of diseases and promoting better health around the world. The WHO has a decentralized structure, operating from its Geneva headquarters and six regional offices. The Secretariat, headed by the Director-General, is responsible for the dayto-day operations of the health agency in collaboration with the regional and country offices. The Director-General is appointed by and responsible to the World Health Assembly (WHA) that sets the agenda and approves the budget of the WHO during the annual meeting held in Geneva, Switzerland.

The WHO's budget operates on a two-year cycle, and in 2018-2019, it received US $\$ 4.4$ billion. To place this number in perspective, this is less than that of a typical major hospital system in the US (McKeever 2020). The organization receives its funding from two main sources. The first of these is assessed contributions, payable by its 194 Member States. ${ }^{7}$ The

7 The amount of the assessed contributions each Member State must pay is calculated relative to the country's wealth and population (See WHO 2021). 
second source is voluntary contributions made by Member States (in addition to their assessed contributions), by other UN organizations, as well as by intergovernmental organizations, philanthropic foundations, and the private sector.

The size of assessed contributions, which are a key source of WHO financing, declined following the 2008/og global financial crisis. To date, about $80 \%$ of the WHO's funding comes from voluntary contributions (WHO 2021a). It is important to note that $96.1 \%$ of all voluntary donations should be spent either according to the contributors' priorities, or are tied to specific programme areas and/or geographical locations and must be spent within a specified timeframe (WHO 2021a). ${ }^{8}$ In other words, the WHO only has full discretion over approximately $3.9 \%$ of all voluntary contributions. This therefore means that the WHO has limited financial autonomy to initiate new programmes for advancing overall global health.

The WHO seemed set to encounter a budget crisis at the start of the COVID-19 pandemic. As the biggest single donor, accounting for $15 \%$ of the WHO's biennial budget in 2018-2019 (McKeever 2020), the US suspended its funding in April 2020. Under the administration of former US president Donald Trump, the US withdrew from the WHO in July 2020, accusing the organization of being too slow to respond to the outbreak in China and being too deferential to the Chinese government (Alpert 2020). The Biden administration has since halted the US withdrawal from the WHO. However, it is widely believed that funding for the WHO still needs to be diversified to pre-empt future budget crises triggered by the withdrawal of key contributors. The availability of sufficient funding is crucial for the WHO to facilitate timely responses in emergency situations, including global infectious disease outbreaks.

In addition to budgetary constraints, the WHO functions under a specific set of rules: the International Health Regulations (IHR). This is a legalbinding global agreement for addressing the risks of the international spread of infectious diseases and is also geared to avoiding unnecessary interference with international travel and trade (WHO 2008). The first version of the legal framework, the International Sanitary Regulations (ISR), was issued in 1951, and there have been a number of revisions since then. Following the eradication of smallpox in 1980, the WHO revised the IHR in 1981 to focus

8 The voluntary contributions are further categorized based on the degree of flexibility the WHO has in deciding how to spend these funds. These are fully flexible core voluntary contributions $(3.9 \%)$, partially flexible thematic and strategic engagement funds $(6 \%)$, and non-flexible specified voluntary contributions (90.1\%; WHO 2021). 
solely on three diseases: cholera, yellow fever, and plague. After the outbreak of Severe Acute Respiratory Syndrome (SARS) in 2003, the organization again revised the IHR in 2005, with these revisions entering into effect in 2007.

This current version of the IHR, also referred to as IHR (2005), has a much broader scope of application than earlier versions, covering 'all events potentially constituting a public health emergency of international concern (PHEIC)' (WHO 2008, 19). The current IHR took into account the reluctance of the Chinese government to share information during the early stages of the outbreak of SARS in 2013. As a result, the current IHR was revised to guarantee that event-related information provided by the country that is notifying the organization about a disease outbreak is not shared with other countries before the WHO has announced that there is a PHEIC. This mechanism aims to 'protect affected countries from any unjustified overreaction by other countries' (WHO 2008, 19). Following an official PHEIC announcement, the WHO is allowed to share information concerning an outbreak with member states.

In addition to enabling information sharing, the declaration of an outbreak as a PHEIC also allows the WHO to activate its funding channels to grapple with global health emergencies in a short period of time. The first WHO funding channel is the Contingency Fund for Emergencies (CFE). Established in 2015, the CFE aims to remedy the WHO's chronic budget deficit and the overdependence on voluntary contributions, allowing the organization the flexibility to scale up operations during disease outbreaks and health emergencies. Funding from this mechanism can be released in less than 24 hours and utilized for financing immediate response activities. One month after declaring COVID-19 a PHEIC, the CFE had provided US $\$ 8.9$ million for COVID-19 when no other funding was available (WHO 2021b). The WHO then called for US $\$ 675$ million in the Strategic Preparedness and Response Plan (SPRP), another WHO funding channel, after the PHEIC declaration was made (WHO 2020a). The WHO has reached the target, having received US $\$ 677$ million from its member states by 1 April 2020 (WHO 2020a). The COVID-19 Solidarity Response Fund is the third funding channel through which individuals, philanthropists, and businesses are able to contribute to WHO-led efforts in responding to public health crises. This Solidarity Response Fund received more than US $\$ 108$ million in donations from over 203,000 individuals and organizations in the first two weeks after the WHO officially declared COVID-19 to be a PHEIC (WHO 2020b).

While this PHEIC-induced global financial mobilization has been quite successful in the case of COVID-19, overall compliance of member states with the IHR has been questionable. For example, the IHR (2005) requires 
member states to strengthen or re-establish the public health infrastructures designed to facilitate early recognition of, and rapid response to, emerging diseases. As part of their commitment to the IHR, participating countries agreed to comply with these rules by 2012 . However, only about one-third of participating countries (64 countries) reported fully achieving the core capacities by 2014 (Gostin and Katz 2016, 276). ${ }^{9}$ Based on these figures, it is not surprising to see that many countries were not ready to deal with COVID-19. It remains to be seen whether countries' approaches to compliance with the IHR have changed as a result of the pandemic.

Apart from the limitations of voluntary compliance with the IHR, we have seen an erosion of member states' trust in the WHO. As globalization has pushed the integration of national economies to the point of interdependence, transportation systems have developed along the same lines. This means that a country cannot physically isolate itself from the rest of the world without inflicting economic damage on itself. As the pandemic hit, an urgent concern for national governments was therefore controlling the in- and outflow of people, especially tourists and migrants. When COVID-19 was declared a PHEIC, the WHO simultaneously advised states to keep borders open on the basis of the IHR. However, almost every country ignored the WHO's advice, and many countries even closed their borders to all nations (Mallapaty 2020), leading to an unprecedented crisis for migrant workers in a number of Asian countries (See Part IV of this book).

In this sense, the complete lockdown of Wuhan in China set an example (see Lo). However, other countries and regions also took measures that affected how human beings could move across space. Foreign workers were barred from entering or leaving Japan, often stranding them abroad away from their jobs, homes, and families. Meanwhile Taiwan's exclusionary guest worker policy made it practically impossible to include all migrants in public health strategies dealing with the pandemic (see Liu). In the case of Indonesia, a country that sends more workers abroad than it receives, a wave of returning migrant workers exerted sudden pressure on the country's healthcare system (see Yazid). The mobility of foreign workers is intricately

9 According to the IHR (2005), member states of the WHO are required to submit a selfevaluation of their core capacities for emergency preparedness and responses. The designated thirteen core capacities include: (1) Legislation and financing; (2) IHR Coordination and National Focal Point Functions; (3) Zoonotic events and the Human-Animal Health Interface; (4) Food safety; (5) Laboratory; (6) Surveillance; (7) Human resources; (8) National Health Emergency Framework; (9) Health Service Provision; (10) Risk communication; (11) Points of entry; (12) Chemical events; and (13) Radiation emergencies. 
linked with global health governance and any strategy to contain a pandemic has to account for the inherently transnational nature of public health crises.

As the case-studies in this volume also show, these developments can have devastating long-term effects for the future of global health governance. This is especially as public trust in governments during health crises has previously proven to be reliant on cooperation with the WHO (see Ishikawa \& Kohara). To regain public trust, some WHO member states called for a more in-depth investigation into the origin of the virus during the WHO's annual decision-making meeting, the World Health Assembly (WHA) in May 2021. This was after an international mission to China earlier the same year proved inconclusive (Larson 2021).

The WHO's investigation and report have also faced criticism for failing to include all essential data, as well as for not fully evaluating theories that COVID-19 was the result of a leak from a laboratory located in the Wuhan area (Miller, Nebehay, and Farge 2021). Critics allege that the WHO has been too deferential to China in its handling of the COVID-19 pandemic and its sharing of data concerning viral origins. They argue that a drastic reform of the WHO is needed to avoid future COVID-like crises. Among the recommendations for the organization's reform are measures to boost the WHO's independence, to give it the power to investigate serious health threats in countries concerned, and to allow it to sound the alarm about risks without waiting for the green light from the countries that have notified it about disease outbreaks (Larson 2021). In the absence of a meaningful reform, it cannot be assumed that the WHO will have an appropriate response to future global health crises. Neither can it be assumed that national governments will listen to the WHO's advice.

\section{Overview of the Volume}

This volume is organized around four themes: health policy in Asia and the global community; the future of global health governance in Asia; domestic responses to COVID-19 in a globalized Asia; and migrant workers and the global economy during COVID-19.

Part I of the book is devoted to an assessment of health policy in Asia and the interactions between the agencies at national, regional, and global levels in times of infectious disease outbreaks. Satoh, for example, highlights the inherent deficiency of the UN system, showing that differences between political values among member states and the principle of upholding state sovereignty make joint actions difficult. This has been demonstrated during the COVID-19 pandemic. The WHO has been unable to make China 
accountable for their poor track record of transparency, issuing guidelines that member states can easily ignore. Moreover, the WHO has been vulnerable to great power competition between the US and China, undermining coordinated disease responses at both regional and global levels. Satoh argues that US action (or inaction) has been by far the most consequential in undermining the confidence of the global community towards the WHO.

In contrast, Koga argues that the Association of Southeast Asian Nations (ASEAN), the key regional organization in Asia, has made a successful effort to build its own capacity to tackle emerging infectious diseases (EIDs). Koga demonstrates how ASEAN's mechanisms to tackle EIDs were been developed prior to the COVID-19 outbreak. ASEAN's health governance efforts were initiated during the Cold War against the backdrop of great power rivalry, long before the COVID-19 outbreak took place. An acceleration of the institutionalization of health cooperation among ASEAN member states then occurred after the SARS outbreak in 2003.

Criticism of the functioning of the WHO has been prolific. However, while critiques of the WHO and the UN system are valid, Ishikawa \& Kohara show that the WHO has nevertheless played a positive role in countries encountering infectious disease outbreaks. In their chapter they offer a statistical investigation into public levels of trust in selected Asian countries before and after the 2003 SARS outbreak. They demonstrate that public trust in government dropped in the countries that were seriously affected by SARS. However, they further show that the deterioration in trust was alleviated in countries hosting a WHO collaborating centre in a domestic research institute. This suggests that such collaboration with the WHO can mitigate declining public trust in national governments during public health crises.

Part II of the book, taking into account the function of the WHO in coordinating disease responses in Asia, attempts to envision the role of the institution in global health governance in the future. Gong \& $\mathrm{Li}$, for example, assess Chinese influence on the WHO and the role of China in global health governance. They argue that Chinese leadership potential has been constrained by several factors. Among these factors, two of the most important are the relatively low contributions that China makes to the funding of the $\mathrm{WHO}$ when compared to traditional donors as well as China's illiberal and fragmented domestic governance structure. As such, it is misleading to assume that China will have sufficient resources to lead global health governance, despite the declining role of the US.

Looking at the attitudes towards the WHO of Asia's other leading power, Van der Veere shows that Japan viewed the WHO as a neutral and scientific source of information during the outbreaks of SARS, Middle East Respiratory 
Syndrome (MERS), and COVID-19. It has often used specific information from the WHO to justify domestic policy goals. However, trust in the organization among policymakers has faltered due to its connection with China. Van der Veere argues that the importance of the WHO in Japan has declined and will continue to do so as long as the organization's neutrality is in doubt, and as long as its guidelines and advice conflict with the country's domestic agenda.

In contrast with the Japanese case, Howe shows that the Republic of Korea (ROK) has seized the opportunity provided by COVID-19 to present itself as a health leader on the world stage. It has positioned itself as an exemplary member state to the WHO over the course of the COVID-19 pandemic. The ROK has not only followed and promoted WHO guidelines, but has also been at the forefront of developing measures to combat COVID-19. Howe further argues that South Korea, as a middle power, is likely to continue its support of the WHO and increase its contribution as a global player in the field of health governance.

While South Korea has increasingly contributed to global health governance, it has frequently been argued that the role of Taiwan in global health governance has remained minimal because of its ambiguous international status and the increasing pressure exerted on it by the People's Republic of China (PRC). Offering a contrasting argument, Lo instead posits that the de facto status of Taiwan may allow it to escape the so-called 'realist trap' that state actors often encounter in global health governance. This trap describes the way that states seeking to engage in international cooperation face problems such as freeriding or failure to comply with existing norms and regulations. In escaping this trap, Lo argues that Taiwan has the potential to participate in global health governance in a meaningful way.

Part III of the book consists of a number of contributions examining domestic responses to COVID-19 in Asia. These case studies explore the various factors that have contributed to, or impeded, an effective response to COVID-19, and their effects on the local population. For example, Nguyen shows that Vietnamese measures to respond to COVID-19 were taken ahead of recommendations made by the WHO in the early stages of the global outbreak. The chapter also shows how the early responses and strict policies adopted in Vietnam have limited the spread of COVID-19 in the country. Yet, despite Vietnam's relative success during 2020, Nguyen also demonstrates the socio-economic impacts that COVID-19 has had on healthcare in Vietnam, calling for the provision of social support to those who are most vulnerable during public health crises.

The chapter by Le \& Nicolaisen describes further underlying factors that have led to the success of the Vietnamese response to COVID-19, namely the 
timeliness in implementation of policies, the country's prior experiences in infectious disease crises, the transparency in communication, and the active social mobilization. Drawing on the extensive research of Vietnam they have conducted in the past, Le \& Nicolaisen argue that the political legitimacy gained by the Vietnamese government could diminish once the pandemic is over. They suggest that this could occur if there is a reversal of transparent communication or a continuation of economic uncertainties during the post-COVID-19 era.

While fast action helped contain the spread of COVID-19 in Vietnam, in their chapter Kamaruddin \& Idris demonstrate that there are more factors than rapid responses in play. They show that the Malaysian government was in the middle of political unrest when COVID-19 struck and had to scramble to respond appropriately. Accordingly, Kamaruddin \& Idris highlight how a professional and well-established civil service system can also be key to shaping a country's pandemic response, even in times of political crises.

However, countries' actions in response to COVID-19 have not only been domestically focused. Kim \& Song show how, in its response to COVID-19, the South Korean government quickly embraced multilateralism. It provided financial resources to key global health initiatives for fair and equal access to COVID-19 vaccines, established global platforms for dialogue, and enhanced its participation in global health institutions. They further demonstrate how the South Korean government has displayed consistent support for the WHO despite swaying public sentiments in South Korea toward the WHO's management of the situation, and a wavering public position towards China.

Part IV, the final section of the book, takes a closer look at the effects of COVID-19 on workers in different Asian nations, in particular non-regular workers and migrant workers. It examines the socio-economic impacts of COVID-19 related measures in societies in Asia. To start this section, Lo discusses the economic and political repercussions on the Chinese economy of the COVID-related Non-Pharmaceutical Interventions (NPIs). Considering the ongoing Sino-US trade disputes and the rising suspicion of China and Chinese firms in the US and Europe, this chapter asks to what extent the Chinese Communist Party (CCP) will be able to save its performative legitimacy through the new economic strategy dubbed the 'dual circulation strategy'. It looks at the implications of Chinese economic reforms in the post-COVID-19 era.

With economic reforms likely to follow after the COVID-19 pandemic in different countries, changes to the mobility and health conditions of migrant workers need to be understood. A chapter by Liu presents Taiwan's successful experience in dealing with the COVID-19 pandemic during 2020. It also shows, 
however, how the pandemic has exposed the vulnerability of migrant workers in Taiwan, who often lack healthcare access and financial support. Presenting these problems faced by migrant workers in Taiwan, Liu calls for changes to the 'divide and exclude' guest worker policy that leaves migrant workers facing dire working conditions and unable to access basic health services.

Low-wage and migrant workers seem to be among the most vulnerable groups during public health crises, when existing inequalities are magnified. In a chapter looking at Japan, for example, Shibata shows how the problems faced by Japanese workers during the COVID-19 pandemic can be best understood when seen through the lens of the country's on-going neoliberal reforms and when changes in Japan's labour market and public health system are taken into consideration. Shibata argues that the problems that Japanese workers face in the labour market and the welfare system have created a number of obstacles to the successful management of the pandemic and the necessary public health interventions. The chapter concludes that the WHO needs to consider the impacts of nation-specific, socio-economic institutions on public health to improve the formulation of its recommendations regarding how to respond to global health crises such as COVID-19.

While Japan is a country that receives migrant workers, Indonesian workers mostly migrate to other countries. The chapter by Yazid describes how Indonesia has responded to the COVID-19 outbreak, which has seen a wave of returnees arriving in the country. Yazid shows that Indonesia's responses are essentially in line with the recommendations of the International Labour Organization (ILO). However, like the arguments made by Shibata about the WHO, Yazid argues that global institutions, in particular the ILO, should take into account the specific characteristics and needs of each country when formulating a global response.

The COVID-19 pandemic has made it clear that public health crises are complex and dynamic processes. As the case-studies in this volume show, we need to thoroughly understand how certain actions result in particular consequences. Even if a response is quick and effective, as in the cases of Vietnam and Taiwan (ROC), there are still segments of the population that can suffer under the new measures put in place. Socio-economically vulnerable groups, such as low-income informal workers, or immigrant workers, are especially prone to marginalization. The success of a response to a sudden public health crisis is therefore not only determined by the number of infections, but by the long-term effects on the public.

Moreover, the politicization of public health has impeded the implementation of a unified global response. This extends from the great power politics between China and the US to the prioritization of a domestic agenda in the 
case of Japan. Across Asia we see that public opinion has a lasting effect on how effective governments can be in responding to new crises. Public trust is quickly eroded and there are only a few means by which governments can try to re-establish a higher level of legitimacy. Domestically, they might do this through transparent communication, rapid and strict responses, media effects, or scientific cooperation with the WHO.

At the same time, however, we have to realize that public health and public trust are transnational. They cross borders, and this is where the politics between nation-states once again come to the fore. Over the course of the COVID-19 pandemic, this has forced multilateral and global institutions like ASEAN, the WHO, and the ILO to play a game of catch up, some more successfully than others. It is therefore paramount for policy makers, health specialists, and the public to realize that health governance is not simply a matter of scientific facts, but a goal that keeps changing, requiring policy makers and citizens alike to adjust to dynamic circumstances.

If this volume can offer one takeaway, it would be this: Asia is diverse, and this diversity has practical, real-world consequences. Understanding the way that Asian countries and regions have variously responded to the COVID-19 pandemic goes beyond the binaries of 'success' and 'failure', 'national' and 'global'. The diverse responses showcase a mixture of causes and consequences that continuously come together or fall apart. We do not know when the next global health crisis will strike, but we know that the complexities of our interconnected world make such a crisis almost inevitable. This makes it essential to look at Asia, to learn lessons where they are available, and to ensure our societies are better prepared and more resilient the next time around.

\section{References}

Alpert, Lukas I. 2020. 'World Health Organization Projects \$1.3 Billion Shortfall in Fighting Covid-19.' The Wall Street Journal, 20 May. Accessed 17 June 2021. https://www.wsj.com/articles/world-health-organization-projects-1-3-billionshortfall-in-fighting-covid-19-11590008871.

Boseley, Sarah. 2015. "World Health Organization" Intentionally Delayed Declaring Ebola Emergency.' The Guardian, 20 March. Accessed 17 June 2021. https://www. theguardian.com/world/2015/mar/2o/ebola-emergency-guinea-epidemic-who.

Gostin, Lawrence O. and Rebecca Katz. 2016. 'The International Health Regulations: The Governing Framework for Global Health Security.' The Milbank Quarterly vol. 94: 264-313. 
Hagenaars, Luc, and Patrick Jeurissen. 2020. Strengheid van het Lockdown Beleid in de Bestrijding van COVID-19, en de Mate waarin deze aansluit bij Nationale Culturen:Een Internationale Vergelijking. Official Exploratory Study, The Hague: Ministerie van Volksgezondheid, Welzijn en Sport.

Hoffman, Steven J. and Sarah L. Silverberg. 2018. 'Delays in Global Disease Outbreak Responses: Lessons from $\mathrm{H}_{1} \mathrm{~N} 1$, Ebola, and Zika.' American Journal of Public Health vol. 108: 329-333.

Kyodo News. 2020. 'WHO Head Deems Japan's Battle against Coronavirus a “Success"'. Kyodo News, 26 May. Accessed 1 June 2021. https://english.kyodonews.net/ news/2020/05/5bbe50741ceb-who-head-deems-japans-battle-against-coronavirus-a-success.html.

Larson, Nina. 2021. 'Countries Urge Deeper Probe of Covid Origins at WHO Meeting after China Mission Inconclusive. Hong Kong Free Press, 26 May. Accessed 18 June 2021. https://hongkongfp.com/2021/05/26/countries-urge-deeper-probeof-covid-origins-at-who-meeting-after-china-mission-inconclusive/.

Mallapaty, Smriti. 2020. 'What the Data Say About Border Closures and COVID Spread.' Nature, 22 December. Accessed 18 June 2021. https://www.nature.com/ articles/d41586-020-03605-6.

McDonell, Stephen. 2017. 'Why China Censors Banned Winnie the Pooh.' $B B C$ News, 17 July. Accessed 25 June 2021. https://www.bbc.com/news/ blogs-china-blog-40627855.

McKeever, Amy. 2020. 'Here's What We Will Lose if the U.S. Cuts Ties with the WHO.' National Geographic, $11 \mathrm{July.} \mathrm{Accessed}$ 17 June 2021. https://www.nationalgeographic.com/science/article/ what-we-will-lose-if-united-states-cuts-ties-with-world-health-organization.

McSweeney, Brendan. 2002. 'Hofstede's Model of National Cultural Differences and their Consequences: A Triumph of Fate - A Failure of Analysis.' Human Relations vol. 55, no. 1: 89-118. https://doi.org/10.1177/0018726702551004.

Meier, Karien, Toivo Glatz, Mathijs C. Guijt, Marco Piccininni, Merel van der Meulen, Khaled Atmar, Anne-Tess C. Jolink, Tobias Kurth, Jessica L. Rohmann, and Amir H. Zamanipoor Najafabadi. 2020. 'Public Perspectives on Protective Measures during the COVID-19 Pandemic in The Netherlands, Germany and Italy: A Survey Study.' PLoS ONE vol. 15, no. 8. https://doi.org/10.1371/journal. pone.0236917.

Miller, John, Stephanie Nebehay, and Emma Farge. 2021. 'WHO Official Says Can't Force China to Give More Information on COVID-19 Origins.' Reuters, 8 June. Accessed 18 June 2021. https://www.reuters.com/world/china/who-officialsays-cant-force-china-give-more-information-covid-19-origins-2021-06-07/.

NTI and the Center for Health Security, Johns Hopkins Bloomberg School of Public Health. 2019. 'GHS Index: Global Health Security Index.' Accessed 
20 January 2021. https://www.ghsindex.org/wp-content/uploads/2020/04/2019Global-Health-Security-Index.pdf.

Qin, Amy, and Javier C. Hernández. 2020. 'China Reports First Death from New Virus.' The New York Times, 11 January. Accessed 1 June 2021. https://www.nytimes. com/2020/01/10/world/asia/china-virus-wuhan-death.html.

Ratcliffe, Rebecca, and Carmela Fonbuena. 2020. 'Inside the Cruise Ship that Became a Coronavirus Breeding Ground.' The Guardian, 6 March. Accessed 1 June 2021. https://www.theguardian.com/global-development/2020/mar/o6/inside-thecruise-ship-that-became-a-coronavirus-breeding-ground-diamond-princess.

Wesley-Smith, Terence \& Goss, Jon (eds). 2010. Remaking Area Studies: Teaching and Learning Across Asia and the Pacific. Honolulu, HI: University of Hawaii Press. WHO. 2008. 'WHO Guidance for the Use of Annex 2 of the International Health Regulations (2005).' Accessed 17 June 2021. https://www.who.int/ihr/revised_annex2_guidance.pdf.

- 2020a. 'WHO Director-General's Opening Remarks at the Mission Briefing on COVID-19.' 2 April. Accessed 17 June 2021. https://www.who.int/directorgeneral/speeches/detail/who-director-general-s-opening-remarks-at-themission-briefing-on-covid-19---2-april-2020.

- 202ob. 'WHO Director-General's Opening Remarks at the Media Briefing on COVID-19.' 27 March. Accessed 17 June 2021. https://www.who.int/dg/speeches/ detail/who-director-general-s-opening-remarks-at-the-media-briefing-oncovid-19---27-march-2020.

-. 2021a. 'How WHO is Funded.' Accessed 17 June 2021. https://www.who.int/ about/funding.

—. 2021b. 'Weekly Operational Update on COVID-19.' 1 March. Accessed 17 June 2021. https://www.who.int/docs/default-source/coronaviruse/wou_2021_1march2021. pdf?sfvrsn=18b1db33_1.

\section{About the Authors}

Anoma Phichai VAN DER VEERE is a Researcher of Modern Asia within the Leiden Asia Centre at Leiden University, and a Research Fellow at the IAFOR Research Center at the Osaka School of International Public Policy. He is currently based at Osaka University, Japan, and has published on health and labour policy, sports, technology, and human rights in Asia and Europe. His latest publications include: 'Japan's Fragmented Response: Technology, Governance, and COVID-19' (Leiden Asia Centre, 2020), 'The Tokyo Paralympic Superhero: Manga and Narratives of Disability in Japan' (Asia Pacific Journal:Japan Focus, 2020), and 'The Technological Utopia: 
Mimamori Care and Family Separation in Japan' (AsiaScape: Digital Asia, 2019). He is currently the principal investigator in the Road to Tokyo 2020 project about local policymaking in disability sports in Tokyo in the run-up to the 2020 Olympic and Paralympic Games, and the 'Understanding the Limitations and Future of Transnational Migrant Labor and Global Health Governance in Asia' project, both funded by the Leiden Asia Centre.

Catherine Yuk-ping LO is an Assistant Professor at University College Maastricht, Maastricht University. She specializes in international relations and global health. Her current research interests include HIV/AIDS in China and India, infectious disease responses in Northeast and Southeast Asian states, antimicrobial resistance (AMR) challenges in the Global South and North, and also global health diplomacy. She is the author of HIV/AIDS in China and India: Governing Health Security (Palgrave Macmillan, 2015). Her book won the 2017 International Studies Association (ISA) Global Health Section Book Prize. Her works appear in such journals as the Australian Journal of International Affairs, Health and Policy Planning, Globalization and Health, and the Journal of Global Security Studies.

Florian SCHNEIDER, PhD, Sheffield University, is Senior University Lecturer in the Politics of Modern China at the Leiden University Institute for Area Studies. He is managing editor of Asiascape: Digital Asia, director of the Leiden Asia Centre, and the author of three books:Staging China: The Politics of Mass Spectacle (Leiden University Press, 2019, recipient of the ICAS Book Prize 2021 Accolades), China's Digital Nationalism (Oxford University Press, 2018), and Visual Political Communication in Popular Chinese Television Series (Brill, 2013, recipient of the 2014 EastAsiaNet book prize). In 2017, he was awarded the Leiden University teaching prize for his innovative work as an educator. His research interests include questions of governance, political communication, and digital media in China, as well as international relations in the East-Asian region. 



\section{PART I}

Health Policy in Asia and the Global Community 



\title{
$1 \quad$ Fighting for a Global Community in a Post-COVID World
}

\author{
Haruko SATOH
}

\begin{abstract}
This chapter argues that the COVID-19 pandemic has exposed the weaknesses of the UN system. This system becomes ineffective when the United States fails to lead during global health crises. At the regional level, the COVID-19 responses in Asian countries have shown that China cannot garner enough trust to replace the US as a leading power to maintain regional order. China was not transparent enough in handling the new virus at the start of 2020. Besides, Beijing's intimidation tactics towards, among others, Hong Kong, Taiwan, and Australia, continued unabated during the first year of the COVID-19 pandemic. These incidents highlight the importance of the US presence in the region. The chapter concludes that restoring trust in the US as the beacon of democracy and openness is crucial.
\end{abstract}

Keywords: international community, United Nations (UN), public health, US-China rivalry, COVID-19, international order

The COVID-19 pandemic has been a profound reminder that international cooperation in the United Nations (UN) system cannot be taken for granted, even in the face of a global health crisis where millions of lives may be at risk. The World Health Organization (WHO) saw its 'directing and coordinating authority' to lead the world out of the pandemic hampered from the outset as it became embroiled in a blame game between the United States and China. The US not only forfeited its leadership role but also became part of the problem as then president Donald Trump refused to publicly aknowledge the gravity of the new virus (Woodward 2020; Forgey and Choi 2020).

Van der Veere, Anoma P., Florian Schneider, and Catherine Yuk-ping Lo (eds), Public Health in Asia during the COVID-19 Pandemic: Global Health Governance, Migrant Labour, and International Health Crises. Amsterdam, Amsterdam University Press 2022 DOI: 10.5117/9789463720977_CHO1 
China tried to compensate for its initial missteps in handling the outbreak by engaging in 'mask and test kits diplomacy' (and later 'vaccine diplomacy') toward affected countries. However, these Chinese diplomatic actions met with a mixed reception, particularly in Asia where many are concerned about China's expansionist intent (Chellaney 2020). While the WHO was vilified for failing to rise above this rivalry between major powers, the context in which this occurred is equally, if not more, problematic. The growing US-China rivalry has far-reaching implications for restoring global trust in the UN system of international cooperation.

This chapter takes a broader view of the COVID-19 pandemic. It sees this as a crisis to the system of global governance in relation to the future of the liberal international order, with a focus on the the Asia-Pacific region.

The responses of Asian states to COVID-19 have varied, ranging from highly organized approaches to muddling through. Asian states were arguably more concerned by the abrupt changes to economic conditions, such as border closures and restricted mobility, than by the debates that divided societies in Europe and North America over effective measures for controlling the spread, such as wearing face masks and lockdowns. ${ }^{1}$

Most Asian states had experienced pandemics before, which meant they were better prepared to manage the crisis in terms of institutional capacities, having already developed aspects of the healthcare system needed to respond to pandemics and information technology that allowed them to carry out 'track and trace' of patients (Fitzgerald and Wong 2020; Pardo et al. 2020). Moreover, for most governments in Asia, hard lockdowns tended to be a reluctantly pursued 'last resort' option. This debunks the notion that Asian governments tend to be more authoritarian and that Asian societies are more compliant and group-oriented (Nikkei Asia 2020).

However, it should be noted that Asia is seeing arguably more profound political changes than other regions of the world. The region is also beset by uncertainty over a US-China rivalry, which is affecting the regional order. In this way, Asia could be seen as a microcosm of what could happen globally with regards to America's diminished standing in the world and its ability to maintain the liberal international order in the face of China's apparent revisionist intentions. By focusing on the Asia-Pacific region, this chapter argues that US actions (or inactions) have been most consequential during

1 Mask-wearing was not a hugely contested issue as East Asians are accustomed to wearing face masks during the flu and hay fever seasons, and also to protect against harmful airborne particulates (PM 2.5) produced by industrial activities and heavy urban traffic. 
this pandemic in undermining the global community's confidence in the UN system as represented by the WHO.

\section{Global Community Matters}

It has been three decades since the Berlin Wall collapsed in 1989, and since the end of the ideological conflict between the 'free world of the West' and the communist bloc, respectively led by the two superpowers, the US and the Soviet Union. In 1991, the first Gulf War then brought together the former enemies to agree at the UN Security Council that Iraq needed to be driven out of Kuwait. This moment sparked the hope that the UN might finally be on the track to function as originally intended, as a world government and a 'peace factory' (Solana 2020).

Although declarations made at the time of a 'new world order' and the 'end of history' (Fukuyama 1989; 1992) were evidently premature, the UN neverthless gained renewed relevance at this time. It was called upon to take charge of a significant portion of problems and challenges of the post-Cold War world. One indicator of this growth in UN activities can be seen in rise in the number of UN Security Council resolutions that have been passed since 1990. Until then, there had been less than 700 resolutions (the resolution that sanctioned the use of force against Iraq was number 678 ). However, in the three decades since 1990 there have been nearly 2000 additional resolutions (UN 2021). Also, importantly, at this time the notion of the 'global' took hold of people's imagination and became part of the lexicon of diplomacy and international politics (Iriye 2002, 159).

The post-Cold War era was characterized by the emergence of a world of borderless, near-global connectivity. The globalization of capitalism brought an unprecedented level of economic development and growth to vast parts of the world. Rapid advances in information technology, especially the advent of the Internet, hastened the pace of this globalization. This in turn increased the level of interdependence between nations and economies at the level of everyday life, creating a realm where the role of states receded to the background. This also meant that the notion of security broadened in tandem with global social and economic transformation. An entirely new category of non-traditional security (NTS) issues, such as climate change, pollution, international terrorism, mass migration, and infectious diseases were identified as threats to international peace and security. In short, it was a world where 'my concern is your concern, too'. 
Yet, the UN system and the global community it represents are inherently fraught with political tension. The differences in the political systems and value systems of the UN member states, combined with the principle of upholding state sovereignty, make joint action difficult (Satoh 2021). Although the UN has a general charter that espouses certain 'universal values', it does not make state membership conditional based on shared values in the way the European Union (EU) does. The UN's paradoxical set-up of respecting the sovereignty of member states while at the same time asking for the transference of sovereign rights requires intense negotiations for consensus-building among member states. At worst, the UN system risks becoming a 'spoils system that puts too many people in important positions for reasons other than competence, lack of accountability, and hypocrisy' (Haass 2020). An example of this might be the way that countries that ignore human rights sit on a UN body meant to uphold them.

In this sense, the problems that the WHO initially encountered in handling the outbreak of COVID-19 were neither unforeseen nor new. First, China's track record for transparency and openness was questionable even before the pandemic (Stanway 2020; Perper 2020). Second, the WHO has no enforcement power and can only issue guidelines for the member states to voluntarily follow. Third, great power rivalry obstructing international cooperation in the UN system is, as explained above, endemic, if not the norm. Last, but not least, intensifying China-US rivalry over trade, geopolitical influence, and concerns about the fate of the rule-based, international order was already foreshadowing difficult times ahead for the UN and multilateralism in general (Satoh 2021).

\section{The Trump Problem}

What the global community did not foresee this time, however, was the extraordinarily uncooperative behaviour of the 'America First' president Donald Trump and his administration in handling the pandemic. After he took office in 2017, and through until his defeat in the 2020 presidential election, Trump wantonly undermined the liberal international order of alliances and international institutions of American design, showing a disdain for multilateralism. However, very few (if any) could have predicted that under Trump the US would become one of the countries worst hit by the pandemic, counting over 300,000 deaths by the end of 2020 . That 2020 was an election year did not help, as Trump appeared more concerned with winning a second term in the November elections than saving lives (Shear 2020). He knowingly ignored the science, tweeted misinformation, and 
turned (non-)mask wearing into a political statement. At the same time, he blamed others, including his chief public health advisor Anthony Fauci, the former president Barack Obama, and above all China and the WHO, for the consequences of the political and public health mayhem that his administration's inaction was causing (Forgey and Choi 2020; Woodward 2020).

China's missteps and the WHO's alleged complicity in downplaying the danger of the new virus rightfully drew international criticism. However, Trump made no attempt to salvage the WHO's reputation, even though the US was its largest donor. Instead, he chose to punish the WHO by first freezing funding and then withdrawing the US from the organization altogether. In this way, Trump essentially reduced the pandemic and the WHO to mere props to enhance his popularity as a MAGA (Make America Great Again) leader who is 'tough on China'.

Under Trump's successor, Joe Biden, the US has now rejoined the WHO, as well as the Paris climate accord which the US officially left in November 2020 (BBC 2020; Biden 2020). These are important steps for the US to recover lost international ground. However, the Trump administration had also chiselled away at America's democracy, which is arguably a deeper concern to the global community esconsed in the US-led liberal international order. For allies and many parts of the world that looked to the US as the beacon of democracy, faith in liberal values, such as in the freedom, human rights, and transparency undergirding this international order, was badly shaken (Kaufman 2017; Stokes 2018).

While the US has never been a natural multilateral player, the effectiveness of international organizations, such as the WHO, in providing global public goods has depended greatly on America's willingness and ability to do the same. That is why Trump's excessive unilateralism and attack on democracy are tantamount to a crisis in the entire international system.

\section{The Impact on the Asia-Pacific}

The Asia-Pacific region is the main arena where China is challenging the USled post-1945 order. This order is frequently described as a hub-and-spokes (San Francisco) system of bilateral alliances (with Japan, South Korea, Australia, the Philippines, and Thailand). The COVID-19 pandemic hit at the time when China was increasingly becoming assertive, while the US commitment to Asia-Pacific regional security was waning under the Trump presidency.

In recent years, the Asia-Pacific region had seen various examples of China's 'wolf warrior' diplomacy and muscle flexing, including the maritime 
territorial disputes in the South and East China Seas, Beijing's attempts to quash demonstrations in Hong Kong, increasing bullying of Taiwan (including its exclusion from the WHO; Chen and Cohen 2020), and the recent intimidation of Australia after it asked China to account for the origins of the coronavirus.

Yet, with Trump behaving more as a kindred spirit of the neo-authoritarians' (Wright 2018) than as a leader of democracies, China's challenge to the status quo was alarming not only to US allies in Europe, but also to democratic allies in Asia, such as Japan, South Korea, and Australia. These allies in Asia all have a higher stake in maintaining the ruled-based, international order in the region. In this regard, the COVID-19 pandemic's impact on the Asia-Pacific regional order offers insights into why restoring trust in the UN system is contingent upon how the US recovers from the international impact of Trumpism.

Regionalism in the sense of community development is a work-in-progress in the Asia-Pacific region. The region does not have a values-based, overarching organization like the EU or a security architecture like the North Atlantic Treaty Organization (NATO). There are democracies as well as communist or military-led authoritarian regimes. The principle of noninterference prevails across the region, such that many consider it as 'the most Westphalian region' (Howe 2020). While security has long relied on the hub-and-spokes system, the spoke states are not necessarily friendly toward each other, as seen in the case of Japan and South Korea. As the chief architect of the regional order, commitment from the US is therefore crucial to the system's cohesion and survival (Richey 2019).

On the other hand, there is another layer of the region's relations that has primarily been economically driven, where Northeast and Southeast Asia are highly economically interdependent and interwoven as a production network (Kimura and Obashi 2011). The Asia Pacific Economic Cooperation (APEC), a regional forum that was established in 1989, is representative of how the region often prioritises economic development and interdependence over issues such as democracy and human rights. Therein lies the paradox where China, Japan, and South Korea can be politically antagonistic toward each other, and yet still maintain closely knit economic ties with each other, and also with Southeast Asia.

In this complicated landscape, regional political dialogue and mechanisms for cooperation have evolved around the Association of Southeast Asian Nations (ASEAN). The institution's role has been indispensable in facilitating multilateral dialogues, such as the ASEAN Regional Forum (ARF), the various ASEAN plus formulas and the East Asia Summit that involve 
all stakeholders, including China, the US and Russia (see the contribution by Koga about ASEAN in this volume).

However, despite these regional forms of cooperation, there continues to be great importance attached to US presence - as a democracy and provider of public goods, such as safety of navigation - as the regional order evolves. Yet, during the Trump presidency the US failed on both fronts: as the beacon of democracy and the guarantor of stability for the region.

Trump's 'tough on China' agenda was welcomed in some security circles in Japan or Australia. However, this agenda did not translate into a stronger hub-and-spokes system or enhanced multilateral dialogue. Instead, the alliance politics and multilateralism in Asia faced difficulties with Trump's transactional style of 'America First' diplomacy, in a similar way to NATO. That said, we need to note here that the attempts by Trump's predecessors, George W. Bush and Barack Obama, to engage with China also had their strengths and weaknesses. These two former presidents presided over the US' China policy during nearly two decades in which China was rapidly transforming. They were responding to a rising country whose economic importance became undisputed. However, the ramifications of a rising China for regional security order were not then clear, nor did they occupy the same central position in in US policy toward Asia as they have since.

Whatever one might think of these two former presidents' policies toward China, however, neither of them allowed the hub-and-spokes system to fragment by ignoring multilateral frameworks in the way that Trump did. For example, a fallout between Japan and South Korea, the two most important US security allies in Asia, took place in the 'shadow' of Trump's theatrical, but ineffective, dealings with the North Korean dictator Kim Jong-un. The Japan-South Korea relationship is now at its lowest point since the normalization of relations between the two countries in 1965 (Satoh 2020). During his time as president, Trump only attended two APEC meetings (2017 in Da Nang, Vietnam and 2020 in Kuala Lumpur, Malaysia, the latter held virtually), and he attended none of the East Asian Summits. His withdrawal of the US from the Trans-Pacific Partnership in his first year in office was an ominous sign for a region where managing economic relations is an integral part of regional stability.

\section{The Trust Deficit}

As has been mentioned earlier in this chapter, the COVID-19 pandemic hit at a time of growing regional uncertainty about the extent to which the US 
would intervene in China's attempts to challenge established norms. At a global level, trust in the US became a rare commodity as its ability to lead diminished. The regional response to the pandemic revealed a complex interplay of 'untrusting' relations between the US, China, and the regional states. This occurred as part of an on-going order transition from one based on the hub-and-spokes system to one where China may become dominant. The question boiled down to trust, and who to trust, with trust remaining in short supply.

People in different parts of Asia, such as in Vietnam, Singapore, and Hong Kong, had not forgotten China's mishandling of the 2002-3 Severe Acute Respiratory Syndrome (SARS) pandemic. At that time, China reportedly hid the outbreak in Guangdong from the WHO for several months (Martin 2020; Perper 2020). Therefore, when COVID-19 outbreaks occurred, China's apparent attempts to once again obfuscate the origins of a new coronavirus, including its unwillingness to allow WHO inspections (Euronews 2021), deepened the region's inherent mistrust towards it. After this, it appeared that no amount of 'mask diplomacy' was going to win China trust from regional states (Kausikan 2020).

However, the humanitarian and political disasters caused by the White House's misinformation about the virus were arguably a deeper concern to people in Asia, and the region's faith in the US took a nose-dive. If China's problem was suppressing inconvenient facts, America's problem was that it had no use for truths, let alone facts.

The attitudes of ASEAN states toward China and the US are, in this case, illuminating as they are informed by their past colonial experiences and the Cold War bipolar system. These experiences have left ASEAN states with a strong desire to maintain autonomy and to avoid entanglement in great power rivalry. The current regional organization was formed, after all, during the ideological divide between the US and the Soviet Union. ASEAN countries remain wary of taking sides, nowadays between the US and China. Maintaining manoeuverability by hedging is their key strategy. They are cautious toward both China and the US, although the sense of threat and suspicion toward China is traditionally greater. A Singaporean think tank's survey (mainly of government officials, academics and researchers in think tanks, and businessmen) proves these points vividly: while a majority $(52.2 \%)$ acknowledge China to be the greatest political and strategic power in Southeast Asia, $53.5 \%$ also see it as a threat (corresponding percentages for the US are $28.7 \%$ and $21.8 \%$, respectively). Regarding what choices ASEAN should make based on US-China rivalry, $48 \%$ chose to 'enhance ASEAN resilience and unity', while $31.1 \%$ chose 'not siding with China or 
US'. This may reflect some wishful thinking, as well as ASEAN's penchant for hedging (ISEAS 2020).

Indeed, ASEAN's preference for avoiding entanglements in great power rivalry makes multilateralism and rule-based international order important. This preference also makes other multilateral players, such as Japan and the EU, attractive in the eyes of ASEAN states. While China and the US, the two great powers that can act unilaterally, are regarded with caution, these other multilateral players are viewed more favourably. In the same survey, over $60 \%$ expressed little or no confidence in China to 'do the right thing to contribute to global peace, security, prosperity and governance'. For the US, this percentage is just under $50 \%$. By comparison, Japan and the EU respectively receive a $61.2 \%$ and $38.7 \%$ confidence rating. Japan is considered a threat by only $5.0 \%$ of respondents, while the $\mathrm{EU}$ is considered a threat by just 3.5\%.

At the same time, only $10.5 \%$ of respondents saw China as a 'responsible stakeholder that respects and champions international law'. This is compared to $15.4 \%$ for the US, $51 \%$ for Japan, and $68 \%$ for the EU (ISEAS 2020, 16-18). That ASEAN does not trust either China or the US to 'do the right thing' should be food for thought for the Biden administration as it plans for the US to make its comeback as a global leader.

However, future US engagement in Asia needs to be more mindful of the complex structure of the political economy in the region. As mentioned earlier, in Asia taking sides or 'decoupling' from China is not an option. This applies to the two main hub-and-spokes allies, Japan and South Korea. We might also note that democracy as a preferred political system has come to matter more than before in Asia, especially at the grassroots level. This is in reaction to what has been described as China's 'salami-slicing strategy'. It has been suggested that China uses this strategy to slowly undermine the integrity of countries and organizations. To this end, it has been argued that China uses a combination of diplomatic and economic tools (such as the creation of debt traps), soft and hard power, and technology to make inroads into countries and organizations (Chellaney 2013).

China's encroachment and the COVID-19 pandemic have highlighted the importance of the political side of the liberal international order. Issues of transparency and accountability have become more important as states have sought to ensure accurate information and trust-based international cooperation to combat COVID-19. Most Asian states, including China, had taken advantage of the liberal economic order for their development. Some of these states have been ambivalent, if not hostile, toward embracing democracy because they saw it as a Western imposition. However, this situation may be changing. The presence of the US as an 'Asian power' in 
this context would be important. However, this makes the damage done to US credibility by the Trump presidency all the more of a grave concern, both to the region as well as to states around the world.

\section{Coda}

It might be worth noting that the pandemic has not necessarily strengthened China's position in the region, although it has emerged as the only country to register economic growth in 2020. If anything, it has demonstrated that China is no more qualified to be a global leader than the US was under Trump. This is largely because China's expansionist actions continued unabated throughout the year when regional states and regions were all struggling to handle the COVID-19 outbreak. Its actions in Hong Kong were arguably most noticeable, with the imposition of its new national security law in June 2020 (Maizland and Albert 2020). That said, there is growing recognition that the question of how democratic governance can take firmer root in Asian countries is tied to the future form and shape of regional order.

Recognition of the need to protect or fight for democracy as a political system, and to keep the liberal international order, has only a limited place in the political evolution of the Indo-Pacific. The goal for many Asian states is not necessarily to become liberal democracies in the model of Europe and North America. Rather, Asia's path to democracy is being shaped out of a social and political struggle that involves pushing back postcolonial legacies, the strong role of the military, a resistance to the imposition of 'universal' values, and a guarded stance against China.

\section{Bibliography}

BBC. 2020. 'Coronavirus: Biden Vows to Reverse Trump WHO Withdrawal.' 8 July. Accessed 10 December 2020. https://www.bbc.com/news/ world-us-canada-53332354.

Biden, Jr, Joseph R. 2020. 'Why America Must Lead Again: Rescuing U.S. Foreign Policy After Trump.' Foreign Affairs, March/April. Accessed 2 November 2020. https://www.foreignaffairs.com/articles/united-states/2020-01-23/ why-america-must-lead-again.

Chellaney, Brahma. 2013. 'China's Salami-slice Strategy.' The Japan Times, 25 July. Accessed 10 October 2020. https://www.japantimes.co.jp/opinion/2013/07/25/ commentary/world-commentary/chinas-salami-slice-strategy/\#.Xu84jpozbIU 
Chellaney, Brahma. 2020. 'China's Expansionism Enters Dangerous Phase.' The Japan Times, 25 August. Accessed 10 November 2020. https://www. japantimes.co.jp/opinion/2020/08/25/commentary/world-commentary/ china-expansionism/

Euronews. 2021. 'WHO Chief Criticizes China after Beijing Fails to Give Clearance for COVID-19 Inspection Mission.' 5 January. Accessed 10 January 2021. https:// www.euronews.com/2021/01/05/who-chief-criticises-china-after-beijing-failsto-give-clearance-for-covid-19-inspection-m.

Fitzgerald, Dominic A., and Gary W.K. Wong. 2020. 'COVID-19: A Tale of Two Pandemics across the Asia Pacific Region.' Pediatric Respiratory Reviews vol. 35: 75-10. Accessed 31 October 2020. https://doi.org/10.1016/j.prrv.2020.06.018.

Forgey, Quint, and Matthew Choi. 2020. "This is Deadly Stuff”: Tapes Show Trump Acknowledging Virus Threat in February.' Politico, 9 September. Accessed 10 November 2020. https://www.politico.com/news/2020/og/og/ trump-coronavirus-deadly-downplayed-risk-410796.

Fukuyama, Francis. 1989. 'The End of History?' The National Interest 16: 3-18.

- 1992. The End of History and the Last Man. New York: Free Press.

Haass, Richard. 2020. 'The UN's Unhappy Birthday.' Project Syndicate, 10 September. Accessed 10 October 2020. https://www.project-syndicate.org/commentary/ united-nations-75th-anniversary-little-to-celebrate-by-richard-haass-2020-09. Howe, Brendan. 2020. 'Comprehensive Security and Sustainable Peacebuilding in East Asia: Reflections on a Post-COVID-19 Operating Environment.' The Korean Journal of Security Affairs vol. 25, no. 1 (July): 5-33.

Iriye, Akita. 2002. Global Community: The Role of International Organizations in the Making of the Contemporary World. Berkeley: University of California Press. Kaufman, Joyce P. (2017). 'The US Perspective on NATO under Trump: Lessons of The Past and Prospects for the Future.' International Affairs vol. 93, no. 2: 251-266. https://doi.org/10.1093/ia/iixoog.

Kausikan, Bilahari. 2020. 'No, China Will Not Get Away with Rewriting History.' Nikkei Asia, 30 March. Accessed 30 March 2020. https:/asia.nikkei.com/Opinion/ No-China-will-not-get-away-with-rewriting-history.

Kimura, Fukunari, and Ayako Obashi. 2011. 'Production Networks in East Asia: What We Know So Far.' ADBI Working Paper 320. Asian Development Bank Institute. November. Accessed 1o October 2020. http://hdl.handle.net/10419/53625.

Maizland, Lindsay, and Eleanor Albert. 2020. 'Hong Kong's Freedoms: What China Promised and How It's Cracking Down.' Backgrounder, 17 February. Council on Foreign Relations. Accessed 6 November 2020. https://www.cfr.org/ backgrounder/hong-kong-freedoms-democracy-protests-china-crackdown.

Nikkei Asia. 2020. 'From Light Touch to Total Lockdown: How Asia Is Fighting Coronavirus.' 20 March. Accessed 10 October 2020. https://asia.nikkei.com/ 
Spotlight/Coronavirus/From-light-touch-to-total-lockdown-How-Asia-isfighting-coronavirus.

Pardo, Pacheco Ramon, Mauricio Avendano Pabon, Xuechen Chen, Bo-jiun Jing, Jeong-ho Lee, Joshua Ting, Takuya Matsuda, and Kaho Yu. 2020. Preventing the Next Pandemic: Lessons from East Asia, Faculty of Social Science \& Public Policy, Kings College London, May. https://www.kcl.ac.uk/eis/assets/ kdefsresearchreport2020-a4-proof2-singlepage.pdf.

Perper, Rosie. 2020. 'The Last Time China Was Hit by a Deadly Illness Like the Wuhan Coronavirus, It Covered It up and 774 People Died. There Are Fears It Could Happen Again.' Insider, 21 January. Accessed 21 January 2020. https://www. businessinsider.com/china-wuhan-virus-sars-similarity-china-coverup-2020-1.

Satoh, Haruko. 2020. 'Japan and Korea: A Fragile Relationship.' East Asian Policy vol.12, no. 3 (July/September): 92-103. https://doi.org/10.1142/S1793930520000252.

- 2021. 'Great Power Relations and Threats to the Liberal International Order.' Hiroshima Peace Research Journal vol. 8: 53-70.

Shear, Michael. 2020. 'Biden Implores Trump to Confront a Surging Pandemic.' The New York Times, 13 November. Accessed 10 January 2021. https://www.nytimes. com/2020/11/13/us/politics/biden-trump-coronavirus-transition.html.

Solana, Javier. 2020. 'Reopening the Peace Factory.' Project Syndicate, 21 September. Accessed 31 October 2020. https://www.project-syndicate.org/commentary/united-nations-anniversary-liberal-international-order-by-javier-solana-2020-o9.

Stanway, David. 2020. 'The Shadow of SARS: China Learned the Hard Way How to Handle an Epidemic.' Reuters, 22 January. Accessed 10 October 2020. https:// www.reuters.com/article/us-china-health-sars-idUSKBN1ZL12B.

Stokes, Doug. 2018. 'Trump, American Hegemony and the Future of the Liberal International Order.' International Affairs vol. 94, no. 1(January): 133-150. https:// doi.org/10.1093/ia/iix238.

United Nations. 2021. As of 29January 2021, the United Nations Security Council Resolution Count Is at 2561. https://www.un.org/securitycouncil/content/resolutions.

Woodward, Bob. 2020. 'Mr Trump Knew It Was Deadly and Airborne.' The New York Times, 9 September. Accessed 31 October 2020. https://www.nytimes. com/2020/og/og/opinion/trump-bob-woodward-coronavirus.html.

Wright, Thomas. 2018. 'The Return to Great-Power Rivalry Was Inevitable.' The Atlantic, 12 September. Accessed 10 October 2020. https://www.theatlantic.com/ international/archive/2018/og/liberal-international-order-free-world-trumpauthoritarianism $/ 569881 /$.

Yusof Ishak Institute of Southeast Asian Studies. 2020. The State of Southeast Asia: 2020 Survey Report, 16 January. ASEAN Studies Centre. Accessed 15 October 2020. https://www.iseas.edu.sg/wp-content/uploads/pdfs/TheStateofSEASurveyReport_2020.pdf. 


\section{About the Author}

Haruko SATOH is co-director of the IAFOR Research Centre at the Osaka School of International Public Policy, Osaka University, a member of IAFOR's Academic Governing Board, and Chair of the Politics, Law \& International Relations section of the International Academic Advisory Board. She is a member of the International Advisory Board at the Leiden Asia Centre at Leiden University. She is a Specially Appointed Professor at the Osaka School of International Public Policy (OSIPP), where she teaches about topics including Japan's relations with Asia and identity in international relations. She was previously part of the MEXT Reinventing Japan project on 'Peace and Human Security in Asia (PAHSA)' with six Southeast Asian and four Japanese universities. 



\title{
$2 \quad$ Countering Emerging Infectious Diseases and COVID-19
}

\author{
The Development of ASEAN's Institutional Arrangements \\ and International Cooperation
}

Kei KOGA

\begin{abstract}
This chapter argues that ASEAN's mechanisms to tackle emerging infectious diseases (EIDs) have been developing gradually since the declaration made at the ASEAN Health Ministers Meeting (AHMM) in 1980. While the 2003 SARS crisis significantly enhanced ASEAN's cooperation to counter EIDs, ASEAN had already laid a foundation for such cooperation before 2003. This chapter shows that ASEAN has tended to focus on the regional rather than global level due to a lack of financial and technical resources and ASEAN's long-standing institutional norms. The recent intensification of great power rivalries, particularly between the United States and China, means that relying on external actors for medical support would entrap ASEAN in great power politics. As such, ASEAN needs to make efforts to build its capacity to respond to EIDs.
\end{abstract}

Keywords: emerging infectious diseases (EIDs), ASEAN, regional cooperation, SARS, COVID-19, institutional norms

\section{$1 \quad$ Introduction}

The Association of Southeast Asian Nations (ASEAN) was established in 1967 as a multi-purpose regional institution that facilitates social, economic, and political cooperation in Southeast Asia. Despite the severe regional strategic environment during the Cold War era, when great powers competed with

Van der Veere, Anoma P., Florian Schneider, and Catherine Yuk-ping Lo (eds), Public Health in Asia during the COVID-19 Pandemic: Global Health Governance, Migrant Labour, and International Health Crises. Amsterdam, Amsterdam University Press 2022 DOI: 10.5117/9789463720977_CHO2 
each other for influence in the region, ASEAN was able to maintain its relative autonomy and promote economic development by strengthening intra-ASEAN cooperation in a comprehensive manner (Acharya 2014, 43-78; Koga 2017, 28-76; Emmers 2018, 349-370).

ASEAN's areas of cooperation include health cooperation. This is because ASEAN has a 'comprehensive' concept of security, which not only focuses on the military but also the economic and social aspects of security. The approach aims to support ASEAN member nations' socio-economic development to increase their domestic regime security, which can also contribute to regional security through the enhancement of national stability (Emmers 2009, 161-163). However, health governance mechanisms have been underdeveloped in ASEAN. Given its limited resources, ASEAN has consistently needed to prioritize some issues over others. Health was not top of the organization's agenda in its nascent days. During the Cold War era, ASEAN made little effort to advance health-related cooperation or to create a mechanism that could manage regional health issues.

This trend somewhat reversed in the post-Cold War era, particularly after the start of the new millennium. The end of the strategic rivalry between two global superpowers generated globalization, which facilitated the economic and social interconnectedness and increased the salience of transnational security issues. These trends contributed to a shift towards ASEAN placing greater attention on health cooperation. Further, the emergence of severe acute respiratory syndrome (SARS) in Southeast Asia in 2003, which had a serious negative socio-economic impact on different ASEAN member nations, facilitated regional health cooperation. During the 2003 SARS outbreak, national governments in the region, the World Health Organization (WHO), and epistemic communities securitized health issues and facilitated the creation of regional cooperation programs (Caballero-Anthony 2018, 6166). However, the development of ASEAN's health governance mechanisms did not occur overnight. Instead, it was a gradual process through which ASEAN created its own mechanisms, enhanced its communication links with international organizations, and facilitated regional cooperation.

This chapter argues that ASEAN's emerging infectious disease (EID) mechanisms have been developing gradually since the declaration made by the ASEAN Health Ministers Meeting (AHMM) in 1980. While the SARS outbreak significantly enhanced ASEAN's cooperation to counter EIDs, ASEAN had laid a foundation for such cooperation before this, and it continued to develop the cooperation afterwards. ASEAN created institutional linkages with the WHO in 1997. It also institutionalized regional cooperation mechanisms after the 2009 HiN1 outbreak. 
Furthermore, ASEAN has tended to focus more on cooperation at the regional rather than global level. This is due in part to a lack of financial and technical resources and ASEAN's long-standing institutional norms, such as the non-interference principle. Regional states are more familiar with these institutional principles and norms - the so-called 'ASEAN Way' - and have significant interests in its aims of increasing regional economic and security stability. The recent intensification of great power rivalries, particularly between the United States and China, means that relying on external actors for medical support would entrap ASEAN in great power politics. As such, ASEAN needs to make efforts to build its own capacity to respond to EIDs.

This chapter is divided into three sections. The first section outlines the three phases seen in the development of ASEAN's health governance, which were caused by three pandemic shocks, namely SARS in 2003, $\mathrm{H} 1 \mathrm{N1}$ in 2009, and COVID-19 in 2020. The second section examines ASEAN's global, regional, and national level cooperative frameworks, highlighting the salience of regional frameworks. The third section discusses the future implications of ASEAN's management of COVID-19, analysing the extent to which it can facilitate regional cooperation amid the ongoing strategic confrontation between the US and China.

\section{The Development of ASEAN's Health Governance}

ASEAN's health governance efforts were initiated during the Cold War. In fact, since the organization first made a declaration about health governance at the second AHMM in 1980, ASEAN has gradually consolidated its health-related institutions (ASEAN 1980a). One of the main aims of ASEAN when it was established was to further socio-cultural development in the ASEAN region. It was believed that this kind of domestic development would contribute to the enhancement of 'self-reliance and self-determination' (ASEAN 198ob). Functional cooperation, such as exchanges of 'information, experience, and expertise' and 'identification of specific regional projects,' was thus endorsed as a first step of institutional development on health (ASEAN 1980b).

In the 1990s, ASEAN also strengthened its ties with global health institutions. Most notably, ASEAN signed a Memorandum of Understanding (MOU) with the World Health Organization (WHO) in 1997 (ASEAN, 1997). One of the most important reasons for concluding such an MOU was because the member states included in the different WHO regional offices do not correspond with the member states of ASEAN. Specifically, the WHO's 
Regional Office for South East Asia (SEARO) includes Indonesia, Myanmar, and Thailand. However, seven other ASEAN member states belong instead to the WHO's Regional Office for the Western Pacific (WPRO). Because these different geographical demarcations would create redundancy and inefficiency, the memorandum signed by ASEAN and the WHO was an attempt to ensure policy coordination among these groupings.

Admittedly, ASEAN's institutional consolidation did not go smoothly. After the second ASEAN Health Ministers Meeting was held in 1980, it then took sixteen years to hold the next three ministerial meetings. The third meeting was held in 1984, the fourth in 1991, and the fifth in 2000 (ASEAN 1991). This demonstrates the relatively low priority placed on health by ASEAN. However, this trend changed in March 2003, when SARS spread in Southeast Asia, disrupting economies and societies in the region. Since then, the development of ASEAN's health governance has moved forwards in three phases; these were prompted by the outbreaks of SARS in 2003, $\mathrm{H}_{5} \mathrm{~N}_{1}$ in 2005, $\mathrm{H}_{1} \mathrm{~N}_{1}$ in 2009, MERS in 2012, and COVID-19 in 2020.

\section{First Phase: Ad hoc Responses}

The first phase started in 2003, when SARS emerged in Southeast Asia. Its economic impact was significant, albeit short-term. For example, the number of tourists and visitors to Malaysia, Thailand, and Singapore dropped by approximately $30 \%$ between March and May 2003. This affected various business sectors in the countries and cost around US $\$ 40$ billion (Barua 2020; Caballero-Anthony 2020, 222). In response to this, ASEAN began to seriously discuss its coordinated responses to the pandemic. However, at this time ASEAN lacked financial resources, expertise in countering EIDs, and medical infrastructure to implement measures that could cover all of Southeast Asia. As a result, ASEAN began to coordinate its policies and operations with external actors.

ASEAN explored utilizing two institutional frameworks: the ASEAN Plus Three (including ASEAN members, namely Brunei, Cambodia, Indonesia, Laos, Malaysia, Myanmar, Philippines, Singapore, Vietnam, Thailand, with China, Japan, and South Korea) and the ASEAN-China framework. Given the geographical proximity and deepening economic interconnectedness of states in these two cooperation frameworks, their interests were relatively congruent. The ASEAN Plus Three (APT) framework was a particularly useful tool for ASEAN to receive external assistance because the framework included the regional economic powers of Japan and China. Indeed, in April 2003, soon after the SARS outbreak, this group 
held a special meeting. The states involved issued a joint statement calling for a coordinated work plan, namely the ASEAN Disease Surveillance Net and the ASEAN Epidemiologic Network (ASEAN 2003a). In 2004, the group created the APT Emerging Infectious Diseases (EID) programme to discuss effective surveillance capacity as well as early warning and rapid response mechanisms (ASEAN 2006). ASEAN and China also held a meeting and issued the Joint Statement of the Special ASEAN-China Leaders Meeting on SARS. Both actions aimed to coordinate measures taken to counter SARS by exchanging information, creating a 'hotline' network, and facilitating research collaboration (ASEAN 2003b). However, the two initiatives were not entirely successful. Their shortcomings stemmed from a lack of general institutional mechanisms. The cooperation of the APT and ASEAN-China frameworks only facilitated ad hoc responses to SARS. These mechanisms did not create longer-term institutions to tackle EIDs.

The trend for limited cooperation on tackling infectious diseases persisted in East Asia (geographically covering both Northeast Asia and Southeast Asia) because not all regional states were equally negatively impacted by SARS. Admittedly, EIDs were seen as a regional issue to some degree. For example, participants in the East Asia Summit (EAS) in 2005, including three APT members, Australia, India, and New Zealand, expressed their concerns about the emergence and the spread of the $\mathrm{H}_{5} \mathrm{~N}_{1}$ virus, also called Avian Flu (ASEAN 2005). As a result, the summit created five priority areas for regional cooperation which included avian flu. However, EIDs were also considered sub-regional specific issues. It was not until the sixth East Asia Summit in 2011 that the scope of EID management was broadened. This modified the objective to 'enlarge cooperation in the fight against avian flu to encompass broader global health issues and pandemic diseases' (ASEAN 2011). In this sense, ASEAN-led organizations were not compelled to create a general framework to tackle infectious diseases in the first phase.

\section{Second Phase: Institutionalization}

The second phase began around the year 2009, as the frequency of infectious diseases affecting the region was gradually increasing. After experiencing SARS in 2003, and then $\mathrm{H}_{5} \mathrm{~N}_{1}$ in 2005 , Southeast Asian states faced a novel influenza H1N1, also called Swine Flu, in 2009 (CDC 2009). In 2013, the Middle East Respiratory Syndrome (MERS) coronavirus emerged. Then in 2015, South Korea faced a MERS outbreak which also created fear across the region (CDC 2015; WHO 2015). The series of pandemics in Asia propelled ASEAN to establish general mechanisms to counter EIDs within ASEAN-led 
institutions. The aim was that these mechanisms would allow ASEAN to rapidly respond to such events by monitoring and analysing situations. Since APT had past experiences in dealing with regional infectious diseases, it became the basic platform used to facilitate the establishment of such functional cooperation.

In fact, APT created more functional mechanisms in addition to its previous effort to implement an EID programme. In 2010, it created the ASEAN Plus Three Partnership Laboratories (APL) to carry out laboratory surveillance and regional networking (ASEAN 2010b). This was supported by the National Institute of Infectious Diseases of Japan (NIID). In 2012, APT health ministers decided to focus on 'Communicable and Emerging Infectious Disease, Pandemic Preparedness and Response' and produced the ASEAN Strategic Framework on Health Development from 2010 to 2015 (ASEAN 2012b). At the same time, the APT also established the 'ASEAN+3 Field Epidemiology Training Network' (FETN; ASEAN 2012a). The ASEAN Emergency Centre (EOC) Network for public health emergencies, which aimed to promote information-sharing among the Public Health Emergency Operations Centres (PHEOCs) of the ASEAN member states, was also established in 2016 (Disease Control Division, Ministry of Health Malaysia 2016).

Alongside these APT functional mechanisms, the ASEAN Secretariat and the WHO signed a Memorandum of Understanding to form a strategic partnership in 2010 (ASEAN 2010a). ASEAN and the WHO, however, needed to resolve a perception gap about disease control. ASEAN suggested that the WHO's pandemic alert levels did not necessarily match the reality in the ASEAN region and needed to be updated (ASEAN 2010a). This shows that information dissemination and sharing were not only the responsibility of global institutions but also that of regional institutions and states (as well as non-state actors). Strategic partnership status would be able to facilitate these activities by more concretely institutionalizing the inter-organizational interactions.

\section{Third Phase: Activation}

The third phase in the development of ASEAN's health governance began in December 2019, when the world saw the first cases of COVID-19 appearing in China. This phase presents more continuity with the second phase than change. However, COVID-19 is the first case where it has been necessary to activate the mechanisms to handle EIDs that ASEAN had established, to assess their utility and to improve them. Indeed, in its response to the COVID-19 crisis, ASEAN has both utilized existing health governance 
mechanisms and created new ones. Admittedly, they did not necessarily function smoothly. During the initial phase, ASEAN was uncertain about how to collectively respond to the virus. In January 2020, China's government said that there was 'no clear evidence of human-to-human transmission' of COVID-19. The WHO cautiously stated the necessity for additional investigation (WHO 2020). Because of such ambiguous information as well as socio-economic differences among the ASEAN member states, these states responded differently to the COVID-19 outbreak. Until 30 January, when the WHO declared COVID-19 to be a 'Public Health Emergency of International Concern (PHEIC)', ASEAN did not take serious political and social measures to respond to the virus. This slow response from ASEAN has been criticized by some scholars and policy-makers (e.g. Djalante et al. 2020).

However, several mechanisms had been activated to fight against COVID-19. For example, on 24 January, the ASEAN EOC Network and the ASEAN Biodiaspora Virtual Center (ABVC) launched its 'Risk Assessment for International Dissemination of 2019-nCoV across ASEAN' (ABVC 2020). This report provided information about the situation regarding the coronavirus in Southeast Asia. It warned about a possibility of humanto-human transmission spreading all over Southeast Asia because of the extensive travel between China and the region (ABVC 2020). Furthermore, the ASEAN EOC Network and ASEAN+3 FETN were actively utilized to share local situational updates (ASEAN 2020a). The ASEAN Defense Ministers' Meeting (ADMM) also agreed to use military resources for information-sharing and best practice sharing through the ASEAN Centre of Military Medicine and the Network of ASEAN Chemical, Biological and Radiological Defense Experts (ASEAN 202ob). After the WHO announcement declared COVID-19 a Public Health Emergency of International Concern, ASEAN also held COVID-19-related meetings on a regular basis. Meetings were held at least four times in February, with China, Japan, and South Korea also participating.

After the WHO declared COVID-19 a 'pandemic' on 11 March, ASEAN diplomatic efforts intensified. This resulted in ASEAN and APT summits as well as a number of foreign ministers' meetings with external states and actors, including the United States and European Union. Because the negative impacts of COVID-19 on member states were cross-sectoral, ASEAN organized a broad range of ministerial meetings in areas such as economics, agriculture, and transportation, allowing the different member nations to coordinate their policies on COVID-19 (ASEAN 2020c). A special APT Summit was held on 14 April and decided to establish the COVID-19 ASEAN Response Fund for public health emergencies (ASEAN 2020d). Since 
April 2020, ASEAN has worked with member states and external actors to gain technical assistance, such as medical equipment and media and information literacy.

Because of the tremendous impact of the ongoing COVID-19 pandemic, it has been difficult for ASEAN to further consolidate its general cooperation mechanisms for combating EIDs. However, in April 2020 Vietnam, which was the chair of ASEAN in 2020, proposed that ASEAN create its own standard operating procedure. As a result, in November 2020, ASEAN formulated its 'Strategic Framework for Public Health Emergency' (ASEAN 202ob; ASEAN 2020e; Koga 2020, 141-143). This framework sets up comprehensive guidelines for the responses to EIDs of member states. Essentially, the 2020 guidelines aim to further enhance regional cooperation and policy coordination. Given ASEAN's continuous emphasis on the importance of the WHO's International Health Regulations (IHR), ASEAN has incorporated these principles in order to maintain coherence with existing international laws (WHO 2005; ASEAN 2020 e, 3). This has created a more structured coordination mechanism between national and regional levels, incorporating the existing frameworks in the field of disaster management and humanitarian assistance. In this strategic framework ASEAN proposed the creation of the ASEAN Centre for Public Health Emergencies and Emerging Diseases (ACPHEED) to coordinate member states' responses, which was formally established in November 2020 with the financial and human resource support of the Japanese government (ASEAN 2020e; ASEAN 202of).

As such, ASEAN has steadily developed its institutional mechanisms for pursuing effective and efficient measures to tackle emerging infectious diseases. It has especially made efforts to develop these mechanisms at those times when it has faced external shocks - SARS in 2003, $\mathrm{H}_{5} \mathrm{~N}_{1}$ in 2005, $\mathrm{H}_{1} \mathrm{~N}_{1}$ in 2009, MERS in 2012, and COVID-19 in 2020.

\section{ASEAN's Cooperation to Counter EIDs: Regional Focus}

ASEAN's health governance mechanisms function at global, regional, and national levels. At the global level, ASEAN has institutional ties with other international organizations, particularly the WHO. The WHO's expertise, information dissemination, and guidelines help ASEAN formulate its own countermeasures in response to EIDs. Despite the US criticism of the WHO, where it accused the organization of being politically too close to China and of having delayed its response to COVID-19, ASEAN has closely worked with the WHO. However, the WHO's advice and protocols, when adopted 
by ASEAN, have often remained as 'guidelines' that do not obligate states to follow them. This is because ASEAN recognizes the existing capability gaps among member states which limit their ability to implement these protocols (Tan 2020). The WHO's International Health Regulations (IHR) are legally binding agreements, created in 2005 , that aim 'to prevent, protect against, control and provide a public health response to the international spread of disease in ways that are commensurate with and restricted to public health risks, and which avoid unnecessary interference with international traffic and trade' (WHO 2005; WHO n.d. (a)). The capacity to implement these nevertheless depends on each state's financial, technical, and political resources, and some states require external assistance to build their capacities.

At the same time, ASEAN's institutional principles, or the so-called 'ASEAN Way', often prevent the organization from taking enforceable measures at the national level. The ASEAN Way consists of several norms, such as the non-interference principle, a consensus-based decision-making process, and non-use of force. More importantly, the great emphasis on protecting state sovereignty makes ASEAN generally reluctant to pressure member states to change their behaviour in the domestic realm. Because of this, persuasion is often employed (Acharaya 2014; Koga 2018, 50-51; Tan 2013, 237-240). This modus operandi partly explains the incongruence in the responses to EIDs that is seen among the ASEAN member states.

To overcome these difficulties, ASEAN has nurtured institutional arrangements that draw external assistance and has simultaneously created inter-state coordination mechanisms. More specifically, ASEAN has focused on the enhancement of regional cooperation, which revolves around ASEAN itself and APT. This is well illustrated by several of the existing mechanisms that have been established to counter EIDs. These include the ASEAN+3 FETN, the ASEAN EOC Network, and the ABVC. The ASEAN+3 FETN was established in 2011 for facilitating capacity building programmes, narrowing the gap in the capabilities of ASEAN member states to manage EIDs, and promoting networks of experts in the region (ASEAN +3 FETN 2012a). The financial resources are voluntarily contributed by the member states, but as the mechanism is under the APT framework, China, Japan, and South Korea are the main contributors (ASEAN+3 FETN 2012b).

The ASEAN EOC Network is not under the APT framework, but is located within ASEAN's own mechanism. This network 'serves as the central location in monitoring disasters and coordinating ASEAN's collective response to disasters' (AHA Centre n.d.). Each member state's Public Health Emergency Operations Centre (PHEOC) can exchange information with others through 
this communication channel (Disease Control Division, Ministry of Health Malaysia 2017). In response to COVID-19, daily communication among the member states has been conducted through WhatsApp, a commercial text messaging mobile application. This has meant that member states can exchange information in a timely fashion and allowed the communication channel to compile contact information about health centres in each member state (ASEAN 2021). This mechanism is financially supported by an external state, the Canadian government, which offered US\$11.6 million in 2013 for its initial establishment (Disease Control Division, Ministry of Health Malaysia 2016).

The ABVC is responsible for conducting big data analysis and data visualization. It is also responsible for disseminating information about the ongoing health situation to the member states and the international community. The idea to establish this centre was adopted in 2019, but the centre became visible in 2020 when it functioned to raise member states' awareness about COVID-19, particularly through its risk assessment reports. The centre has two computer programmes - the Explorer Tool and the Insights Tool. The former tool aims to track trends of infectious diseases, to find out about local transmissions, and to enable users to communicate with each other (ASEAN n.d.). The latter tool helps health centres in the analysis of the threat posed by different EIDs, sorting out the most significant events that would pose health risks at the national and regional levels (ASEAN n.d.). This centre was also financially supported by the Canadian government in 2019 (ASEAN 2019).

The characteristics of ASEAN's health governance mechanisms are therefore mainly shaped by ASEAN's institutional principles, norms, and rules. These mechanisms are made to be compatible with the ASEAN Way and with the idea of receiving external assistance to build member states' capacity. Because today EIDs have become one of ASEAN's and the world's top non-traditional security issues, ASEAN has been able to build its own mechanisms with external assistance. There are also other ASEAN mechanisms, such as the ASEAN Risk Assessment and Risk Communication Centre (ARARC) and Regional Public Health Laboratories Network (RPHL). These mechanisms facilitate laboratory readiness and the combating of fake news. They are supported by external actors, such as the United States (US Mission to ASEAN 2020).

ASEAN makes the most of its institutional weaknesses to attract assistance from regional states while emphasizing the importance of the ASEAN Way to prevent external actors from interfering excessively. In so doing, ASEAN has been relatively successful in utilizing these institutional frameworks in countering COVID-19 since January 2020. 


\section{Three Challenges to ASEAN's Collaboration in Countering Infectious Diseases}

There is no guarantee that ASEAN can sustain the development model it has adopted in the future. At the global level, in April 2020 the Access to COVID-19 Tools (ACT) Accelerator was launched by the WHO, the European Commission, France, and the Bill \& Melinda Gates Foundation. This aims to ensure diagnosis investment, equal distribution of treatment, and access to vaccines in developing states including some ASEAN member states (under the so-called 'COVAX' programme; [WHO, n.d.(c)]). Nevertheless, the international community has yet to find an effective way to contain COVID-19. Many countries have experienced second and third waves since late 2020 and the spread of mutated COVID-19 variants has also occurred in numerous places. In this context, there are three main challenges to ASEAN's health governance.

The first is to reduce ASEAN's dependence on external actors for materials, particularly for financial assistance. ASEAN effectively created its own institutional system to establish health governance mechanisms with external assistance from regional major powers. However, the negative impacts of COVID-19 have severely affected the financial capabilities of some states in the region. In the short-term, these states will continue to offer ASEAN a certain amount of assistance. However, if the situation worsens, it is not clear how sustainable their assistance will be and the degree to which ASEAN's health governance mechanisms can maintain their operations.

The second challenge is to manage the normative constraints that are created by ASEAN's adherence to the ASEAN Way. To be sure, the ASEAN Way has been a useful tool for the member states to maintain their political autonomy and independence in Southeast Asia. Nevertheless, given the high degree of trade interdependence among ASEAN member states, the mishandling of COVID-19 or another EID by member states, through such things as the imposition of trade restrictions, would affect the entire region (e.g., Pitakdumrongkit 2020). It is not realistic to see any radical change in ASEAN's traditional norms and rules in the near future, and ASEAN's 'Strategic Framework for Public Health Emergency' has advanced its own coordination mechanism. However, ASEAN's emphasis on state sovereignty would make it difficult for the association to manage complex emergency situations, such as those where a national government collapses or becomes dysfunctional because of EIDs.

The third challenge is to balance ASEAN's geostrategic position in the context of intensified US-China great power rivalry. While regional health 
cooperation in Asia is based on transnational interests, such cooperation is still influenced by regional politics. At the heart of the Indo-Pacific region, ASEAN is located in a geo-strategically important area. Its multilateral frameworks have been, and continue to be, a source of political legitimacy in East Asia, which attracts many regional powers, including the United States, China, Japan, India, and Australia (Koga 2019, 288, 300). These regional powers are important for ASEAN member states, because they help to provide technical and financial resources to enhance ASEAN's capacity in countering EIDs. However, if the strategic rivalries between these powers continue to intensify, ASEAN will have to carefully and collectively assess its position. It will need to determine from which regional powers, and under what conditions, it can accept financial and medical resources. This is because if the United States and China, in attempting to expand their spheres of influence, drive a wedge between different ASEAN member states by offering them economic, medical, and technical assistance, then the organization will face difficulties in maintaining its unity. This will then in turn affect ASEAN's ability to collectively respond to EIDs.

These three challenges are inherently related to each other. It is not possible, or even advisable, for ASEAN to pursue complete autonomy. However, it is important to mitigate the negative impacts that may come from external factors. Essentially, prevention is the most cost-effective means of managing EIDs, and thus, the enhancement of ASEAN's preventive capabilities is imperative for national and regional security.

\section{Conclusion}

ASEAN has seen relative success in formulating its health governance mechanisms in the post-SARS era. By consolidating its political cooperative frameworks during the 2000s, ASEAN gradually nurtured functional cooperation in countering EIDs. This involved the creation of the ASEAN ECO Network and ASEAN+3 FETN. Facing the COVID-19 pandemic, ASEAN utilized these mechanisms and activated new ones, such as ABVC. This culminated in the production of the 2020 'Strategic Framework for Public Health Emergency', which included a set of standard operating procedures, as well as the establishment of ACPHEED in 2020.

This became possible because ASEAN constructed its own regional institutional system. Through this system, ASEAN can maintain its own political autonomy, provide political legitimacy in East Asia by promoting regional multilateralism, and gain political support and material assistance 
from regional powers, including the United States, China, and Japan. This is partly why ASEAN has been able to utilize regional arrangements, particularly the APT, in facilitating its health governance mechanisms. Nevertheless, it is not clear whether ASEAN can sustain this institutional advantage in the future. It faces the challenges of intensifying US-China strategic competition and the ongoing negative consequences of COVID-19.

The year 2020 clearly shows that international relations in East Asia are shaped not only by power politics, but also by transnational security issues, such as threats which the COVID-19 pandemic poses. ASEAN's institutional focus on non-traditional security issues has thus far provided venues for Southeast Asian and Northeast Asian states to coordinate their policies and collectively respond to the COVID-19 pandemic. However, in the future, ASEAN's success ultimately depends on how member states build their own capacity to adequately respond to EIDs without significant assistance from external actors.

\section{References}

ABVC (ASEAN Biodiaspora Virtual Center). 2020. 'Risk Assessment for International Dissemination of 2019-nCoV across ASEAN: As of January 24, 2020.' 24 January. Accessed 14 January 2021. https://ddc.moph.go.th/viralpneumonia/eng/file/ RiskAssessment/EngVers_240163.pdf.

Acharya, Amitav. 2014. Constructing a Security Community in Southeast Asia:ASEAN and the Problem of Regional Order [3rd edition]. Oxon and New York: Routledge.

AHA Centre. n.d. 'What We Do.' Accessed 14 January 2021. https://ahacentre.org/ what-we-do/.

ASEAN. n.d. 'ASEAN BioDiaspora Virtual Centre (ABVC) for Big Data Analytics and Visualization.' Accessed 14January 2021. https://asean.org/?static_post=updatesasean-health-sector-efforts-combat-novel-coronavirus-covid-19.

- 1980a. 'Declaration The ASEAN Health Ministers on Collaboration on Health Manila, 24 July 1980.' Accessed 14 January 2021. https://asean.org/declarationthe-asean-health-ministers-on-collaboration-on-health-manila-24-july-198o/.

—. 1980b. 'Joint Communique of the Second ASEAN Health Ministers Meeting Manila, 22-24 July 1980.' Accessed 14 January 2021. https://asean.org/?static_ post=joint-communique-of-the-second-asean-health-ministers-meeting-manila22-24-july-1980.

-. 1991. 'Joint Press Statement: The Fourth ASEAN Health Ministers Meeting, Indonesia, 4-5 December 1991.' Accessed 14 January 2021. https://asean. org/?static_post=joint-press-statement-the-fourth-asean-health-ministersmeeting-indonesia-4-5-december-1991. 
- 1997. 'Memorandum of Understanding between the Association of Southeast Asian Nations and the World Health Organization.' Accessed 14 January 2021. http://arc-agreement.asean.org/file/doc/2015/o1/memorandum-of-understanding-between-asean-and-the-who.pdf.

- . 2003a. 'Joint Statement ASENA+3 Ministers of Health Special Meeting on SARS, Kuala Lumpur, Malaysia.' 26 April. Accessed 14 January 2021. https://asean. org/?static_post=joint-statement-asean-3-ministers-of-health-special-meetingon-sars-kuala-lumpur-malaysia-26-april-2003.

- 2003 b. 'Joint Statement of the Special ASEAN-China Leaders Meeting on the severe acute respiratory syndrome (SARS) Bangkok.' 29 April. Accessed 14 January 2021. https://asean.org/joint-statement-of-the-special-asean-chinaleaders-meeting-on-the-severe-acute-respiratory-syndrome-sars-bangkok/.

-. 2005. 'East Asia Summit Declaration on Avian Influenza Prevention, Control and Response, Kuala Lumpur, Malaysia, 14 December 2005.' Accessed 14 January 2021. https://asean.org/?static_post=east-asia-summit-declaration-on-avian-influenzaprevention-control-and-response-kuala-lumpur-14-december-2005.

- 2006. 'Joint Statement of the Second ASEAN Plus Three Health Ministers Meeting 'Unity in Health Emergencies' Yangon.' 26 June. Accessed 14 January 2021. https:// asean.org/joint-statement-of-the-second-asean-plus-three-health-ministersmeeting-unity-in-health-emergencies-2/.

- 2010a. 'Joint Statement of the 1oth ASEAN Health Ministers Meeting, Singapore, 22 July 2010.' 22 July. Accessed 14 January 2021. https://asean. org/?static_post=joint-statement-of-the-1oth-asean-health-ministers.

- 2010b. 'Joint Statement of the 4th ASEAN+3 Health Ministers Meeting, Singapore, 23 July 2010.' 23 July. Accessed 14 January 2021. https://asean. org/?static_post=joint-statement-of-the-4th-asean3-health-ministers-meetingsingapore-23-july-2010.

- 2011. 'Chairman's Statement of the Sixth East Asia Summit, Bali, Indonesia, 19 November 2011.' Accessed 14 January 2021. https://www.eria.org/2011_1118_ Chairs\%2oStatement\%2019th\%20ASEAN\%2oSummit.pdf.

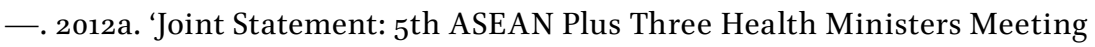
6 July 2012, Phuket, Thailand.' Accessed 14 January 2021. https://asean.org/wpcontent/uploads/images/2012/Economic/AHMM/5th\%2oASEAN\%2oPlus\%2o Three\%2oJoint\%2oStatement_Final.pdf.

- 2012b. 'ASEAN Plus Three Leaders' Joint Statement on the Commemoration of the 15th Anniversary of the ASEAN Plus Three Cooperation 19 November 2012, Phnom Penh, Cambodia.' Accessed 14 January 2021. https://www.asean.org/ wp-content/uploads/images/documents/APT\%2oLeaders\%2oJoint\%2oStatement\%2o-final.pdf. 
- 2019. 'ASEAN Health Cooperation on the Mitigation of Biological Threats.' Regional Workshop for the ASEAN State Parties to the Biological Weapons Convention on Preparedness to Respond to the Deliberate Use of Biological Weapons, 6-7 June. Accessed 14 January 2021. https://www.unog.ch/ 80256EDDoo6B8954/(httpAssets)/95609757952622EFC1258420004F1589/\$fi le/ASEAN+Presentation.pdf.

-. 2020a. 'ASEAN Health Sector Responds to 2019 Novel Coronavirus Threat.' 30 January. Accessed 14 January 2021. https://asean.org/ asean-health-sector-responds-2019-novel-coronavirus-threat/.

- 2020b. 'Declaration of the Special ASEAN Summit on Coronavirus Disease 2019 (COVID-19).' 14 April. Accessed 14 January 2021. https://asean.org/storage/2020/04/ FINAL-Declaration-of-the-Special-ASEAN-Summit-on-COVID-19.pdf.

-. 2020c. 'Statement of ASEAN Ministers on Agriculture and Forestry in Response to the Outbreak of the Coronavirus Disease (Covid-19) to Ensure Food Security, Food Safety and Nutrition in ASEAN.' 14 April. Accessed 14 January 2021. https:// asean.org/statement-asean-ministers-agriculture-forestry-response-outbreakcoronavirus-disease-covid-19-ensure-food-security-food-safety-nutritionasean/.

—. 2020d. 'Joint Statement of the Special ASEAN Plus Three Summit on Coronavirus Disease 2019 (COVID-19).' 14 April. Accessed 14 January 2021. https://asean. org/storage/2020/04/Final-Joint-Statement-of-the-Special-APT-Summit-onCOVID-19.pdf.

- 2020e. 'ASEAN Strategic Framework for Public Health Emergencies (As of 10 November 2020).' Accessed 14 January 2021. https://asean.org/storage/2020/11/4ASEAN-Strategic-Framework-on-PHE_Final.pdf.

- 2020f. 'Chairman's Statement of the $23^{\text {rd }}$ ASEAN-Japan Summit.' Accessed 4 June 2021. https://asean.org/storage/48-Final-Chairmans-Statement-of-the23rd-ASEAN-Japan-Summit.pdf.

-. 2021. 'ASEAN Emergency Operations Center (EOC) Network for Public Health.' Accessed 14 January 2021. https://asean.org/?static_post=updates-asean-healthsector-efforts-combat-novel-coronavirus-covid-19.

ASEAN+3 FETN. 2012a. 'ASEAN+3 FETN.' June. Accessed 14 January 2021. http:// www.aseanplus3fetn.net/read_more_pdf/FETNP1-10.pdf.

—. 2012b. 'APPENDIX A: ASEAN+3 FETN Terms of Reference.' June. Accessed 14January 2021. http://www.aseanplus3fetn.net/read_more_pdf/FETNP31-40.pdf. Barua, Akrur. 2020. 'Economic Impact of Epidemics and Pandemics in Asia since 2000.' Deloitte Insights, 20 May. Accessed 14 January 2021. https://www2.deloitte. com/us/en/insights/economy/asia-pacific/economic-impact-of-epidemics-andpandemics.html. 
Caballero-Anthony, Mely. 2018. Negotiating Governance on Non-Traditional Security in Southeast Asia and Beyond. New York: Columbia University Press.

-. 2020. 'ASEAN's Multilateral Path through the Pandemic.' Current History vol. 119, no. 818: 222-227.

CDC (Centers for Disease Control and Prevention). 2009. '2009 H1N1 Pandemic (H1Nipdmog virus).' Accessed 14 January 2021. https://www.cdc.gov/flu/ pandemic-resources/2009-hını-pandemic.html.

—. 2019. 'Middle East Respiratory Syndrome (MERS).' 2 August. Accessed 14 January 2021. https://www.cdc.gov/coronavirus/mers/index.html.

Disease Control Division, Ministry of Health Malaysia. 2016. 'ASEAN-Canada Collaboration on Mitigation of Biological Threats in the ASEAN Region.' ASEANEOC Newsletter vol. 1, no. 1. https://asean.org/storage/2016/12/ASEAN-EOC-Newsletter1.pdf.

-. 2017. 'Study on the Utilization of Risk Assessment \& Risk Communication at AMS PHEOC during Outbreak or Public Health Event.' ASEANEOC Newsletter vol. 1, no. 5. Accessed 14 January 2021. https://asean.org/asean-socio-cultural/aseanhealth-ministers-meeting-ahmm/publications-documents/\#b75bf704f98b4dbc3.

Djalante, Riyanti, Laely Nurhidayah, Jonatan Lassa, Hoang Van Minh, Yodi Mahendradhata, Nguyen Thi Ngoc Phuong, Angelo Paolo L Trias, Michelle Ann Miller, Susanti Djalante, and Muhammad Sabaruddin Sinapoy. 2020. 'The ASEAN's responses to COVID-19: A Policy Sciences Analysis.' April. Accessed 14 January 2021. https://psyarxiv.com/8347d/download/?format=pdf.

Emmers, Ralf. 2009. 'Comprehensive security and resilience in Southeast Asia: ASEAN's approach to terrorism.' The Pacific Review vol. 22, no. 2:159-177.

-. 2018. 'Unpacking ASEAN Neutrality: The Quest for Autonomy and Impartiality in Southeast Asia.' Contemporary Southeast Asia vol. 40, no. 3: 349-370.

Koga, Kei. 2017. Reinventing Regional Security Institutions in Asia and Africa: Power shifts, ideas, and institutional change. Oxon and New York: Routledge.

—. 2018. 'ASEAN's Evolving Institutional Strategy: Managing Great Power Politics in South China Sea Disputes.' The Chinese Journal of International Politics vol. 11, no. 1: 49-8o.

-. 2019. 'Japan's 'Free and Open Indo-Pacific' Strategy: Tokyo's Tactical Hedging and the Implications for ASEAN.' Contemporary Southeast Asia vol. 41, no. 2: 286-313.

- 2020. 'Japan-Southeast Asia Relations: Great Disruption: Uncertainty over the Indo-Pacific.' Comparative Connections vol. 22, no. 1: 137-148. Accessed 14January 2021. http://cc.pacforum.org/wp-content/uploads/2020/05/14_2001_JapanSea-1.pdf.

Pitakdumrongkit, Kaewkamol Karen. 2020. 'COVID-19 and ASEAN Cooperation: The State of Play and Ways Forward.' AsiaGlobal Online, 7 October. Accessed 14 January 2021. https://www.asiaglobalonline.hku.hk/covid-19-and-aseancooperation-state-play-and-ways-forward. 
Tan, Hsien-Li. 2020. 'From SARs to COVID-19: Reflections on ASEAN's Collective Response to Public Health Crises.' The Business Times, 1 June. Accessed 14 January 2021. https://www.businesstimes.com.sg/asean-business/from-sars-to-covid19-reflections-on-asean $\% \mathrm{E} 2 \% 80 \% 99$ s-collective-response-to-public-health.

Tan, See Seng. 2013. 'Herding Cats: The Role of Persuasion in Political Change and Continuity in the Association of Southeast Asian Nations.' International Relations of the Asia Pacific vol. 13, no. 2: 233-265.

US Mission to ASEAN. 2020. '[Fact Sheet] U.S. Support for ASEAN in Fighting COVID-19.' 31 March. Accessed 14 January 2021. https://asean.usmission.gov/ fact-sheet-u-s-support-for-asean-in-fighting-covid-19/.

WHO (World Health Organization). n.d.(a) 'Ten Things You Need to Do to Implement the IHR.' Accessed 14 January 2021. https://www.who.int/ihr/ how theywork/1othings/en/.

—. n.d.(b). 'MERS outbreak in the Republic of Korea, 2015.' Accessed 14 January 2021. https://www.who.int/westernpacific/emergencies/2015-mers-outbreak.

—. n.d.(c). 'The Access to COVID-19 Tools (ACT) Accelerator.' Accessed 14 January 2021. https://www.who.int/initiatives/act-accelerator.

-. 2005. 'International Health Regulations (2005).' Accessed 14 January 2021. https://www.who.int/health-topics/international-health-regulations\#tab=tab_1.

-. 2020. 'Listings of WHO's response to COVID-19.' Accessed 14 January 2021. https://www.who.int/news/item/29-06-2020-covidtimeline.

\section{About the Author}

Kei KOGA is an Assistant Professor at the Public Policy and Global Affairs Programme, School of Social Sciences, Nanyang Technological University (NTU). His research focuses on international relations theory, International Security, International Institutions, and East Asian security, including the transformation of US-bilateral security networks and ASEAN-led institutions in the Indo-Pacific region. His recent publications include the book Reinventing Regional Security Institutions in Asia and Africa (Routledge 2017), 'Japan's “Indo-Pacific” Question: Countering China or Shaping a New Regional Order?', International Affairs (2020), 'The Concept of "Hedging” Revisited: The Case of Japan's Foreign Policy Strategy in East Asia's Power Shift', International Studies Review (2018), and 'ASEAN's Evolving Institutional Strategy: Managing Great Power Politics in South China Sea Disputes', Chinese Journal of International Politics (2018). His current book project is Managing Great Power Politics: ASEAN, Institutional Strategy, and the South China Sea. 



\title{
3 The Outbreak of Infectious Disease and Trust in Government in Asian Countries
}

\author{
Yumi ISHIKAWA and Miki KOHARA
}

\begin{abstract}
During infectious disease outbreaks, governments issue various public directives to curb disease spread. Disease containment measures sometimes include strong behavioural restrictions. Compliance with these public health restrictions depends on people's trust in government. This chapter applies statistical analysis to study the impact of the SARS outbreak on the levels of public trust in government in Asia. The analysis shows that the 2003 SARS outbreak reduced people's trust in government in Asian countries. It also indicates that this loss was mitigated when there was collaboration between the government and the World Health Organization (WHO). This finding suggests that a collaborative relationship with international organizations such as the WHO encourages the public to comply with restrictive measures implemented by governments.
\end{abstract}

Keywords: public trust, World Health Organization(WHO), SARS, public health, political legitimacy, East and Southeast Asia

\section{Introduction}

What is the relationship between the outbreak of an infectious disease and public trust in government in Asian countries? The relationship should be examined because it has important policy implications. During the outbreak of an infectious disease, governments issue various public directives to curb its spread. These can include not only individual preventive behaviour, such as hand hygiene and mask wearing, but also social behavioural restrictions

Van der Veere, Anoma P., Florian Schneider, and Catherine Yuk-ping Lo (eds), Public Health in Asia during the COVID-19 Pandemic: Global Health Governance, Migrant Labour, and International Health Crises. Amsterdam, Amsterdam University Press 2022 DOI: 10.5117/9789463720977_CHO3 
including quarantine and store closures. Whether these restrictions are followed (i.e., whether people follow the government's instructions) depends to a large degree on trust in government. In countries where an infectious disease outbreak reduces trust in the government, restrictions will not be effective to prevent the spread of disease, whereas in countries where public trust in government is higher, the spread will be controlled more easily.

This chapter examines how infectious disease outbreaks affect public trust in government in Asian countries, focusing on the 2003 SARS epidemic as a case study. Specifically, the chapter clarifies how social trust changed in the affected countries after the serious SARS epidemic. It also illustrates how the collaboration between the respective government and health-related organizations such as the World Health Organization (WHO) affects the level of trust. Networking with the WHO may contribute to alleviating failing public trust in government if the organization successfully shares crucial information with national governments.

Many academic studies suggest that unexpected negative shocks damage trust in governments. These unexpected shocks include natural disasters (Lazarev et al. 2014, 641; Nicholls and Picou 2013, 344), financial crises (Armingeon and Guthmann 2014, 423; Kroknes, Jakobsen, and Grønning 2015, 700), and infectious disease outbreaks (Sibley et al. 2020, 618; Kye and Hwang 2020, 1; van der Weerd et al. 2011, 1; Bangerter et al. 2012, 1). Recent studies regarding pandemics, however, show opposite results. Sibley et al. (2020, 618) found that trust in government improved during the first eighteen days of lockdown amid the COVID-19 outbreak in New Zealand. Using individual panel data, Kye and Hwang $(2020,1)$ also showed that the level of trust in government in South Korea increased after the COVID-19 outbreak. In the case of the 2009 influenza $\left(\mathrm{H}_{1} \mathrm{~N}\right)$ pandemic, public trust in government was high in the early phase of the outbreak but decreased in the latter phase of the pandemic (van der Weerd et al. 2011, 1; Bangerter et al. 2012, 1).

These contrasting studies demonstrate that the level of trust in government varies depending on the type of negative shock as well as the response provided by the government to the crisis. In the case of infectious disease outbreaks, it is necessary for the government to assess correct data, understand scientific evidence, and provide reliable information to the public. Most people in society have limited medical knowledge, which can cause an increase in anxiety. People may believe misleading emotional information more than scientific evidence. This could lead to non-compliance with public health measures, or to secondary effects of the outbreak such as increases in violent crimes and mental health problems.

When a national government seeks to provide effective assessment and transmission of reliable information, the WHO can play an important role. 
As will be explained in the next section, in the early stages of the 2003 SARS epidemic the WHO launched a collaborative research project on SARS diagnostics. This established an international network among research centres to share outcomes of investigations of clinical samples of SARS cases in real time. The members of this collaborative research effort were research institutes, parts of universities or academies around the world. During the 2003 SARS crisis, those countries with a research group that joined this WHO project could get prompt and accurate information. As such, it was easier for these countries with a WHO research collaboration to publish scientific evidence quickly and urge their populations to adopt appropriate preventive behaviour. These countries could also devise effective policies to mitigate the spread of infection based on reliable information.

The discussion in this chapter is based on a statistical investigation of a unique dataset containing information on public levels of trust in different Asian countries before and after the 2003 SARS epidemic. Our empirical results show that, after the onset of the SARS epidemic, public trust in government declined in those countries that were seriously affected. The deterioration in trust, however, was alleviated in countries hosting a WHO Collaborating Centre in a domestic research institute. The next section summarizes how the 2003 SARS epidemic affected Asian countries and how the governments coped with the outbreak.

\section{SARS Epidemic and Reactions by Governments and the WHO}

SARS was the first severe novel infectious disease of the 21st century, affecting 26 countries ( 29 regions) and causing 8096 cases and 774 deaths (WHO 2003a, 1, 2005). According to the WHO (2003a, 1), the novel coronavirus emerged in Guangdong Province, China, in November 2002. However, details about this infectious disease were not reported to the WHO until 11 February 2003. Meanwhile, the virus began to spread outside the province, causing infection clusters (for example, those in a Hong Kong hotel). The virus then spread to other countries via infected but undiagnosed travellers.

The first case was identified in Hanoi, Vietnam, on 26 February 2003. This case was tied to the infection cluster in the hotel in Hong Kong. Soon after the first reported case in Vietnam, the virus spread to other parts of Asia. The WHO issued a global epidemic alert on 12 March 2003, and identified a newly discovered coronavirus as its cause. The WHO then issued safety guidelines and warnings against traveling to the infected regions, including Guangdong, Hong Kong, Taiwan, and Toronto, Canada. At the same time, 


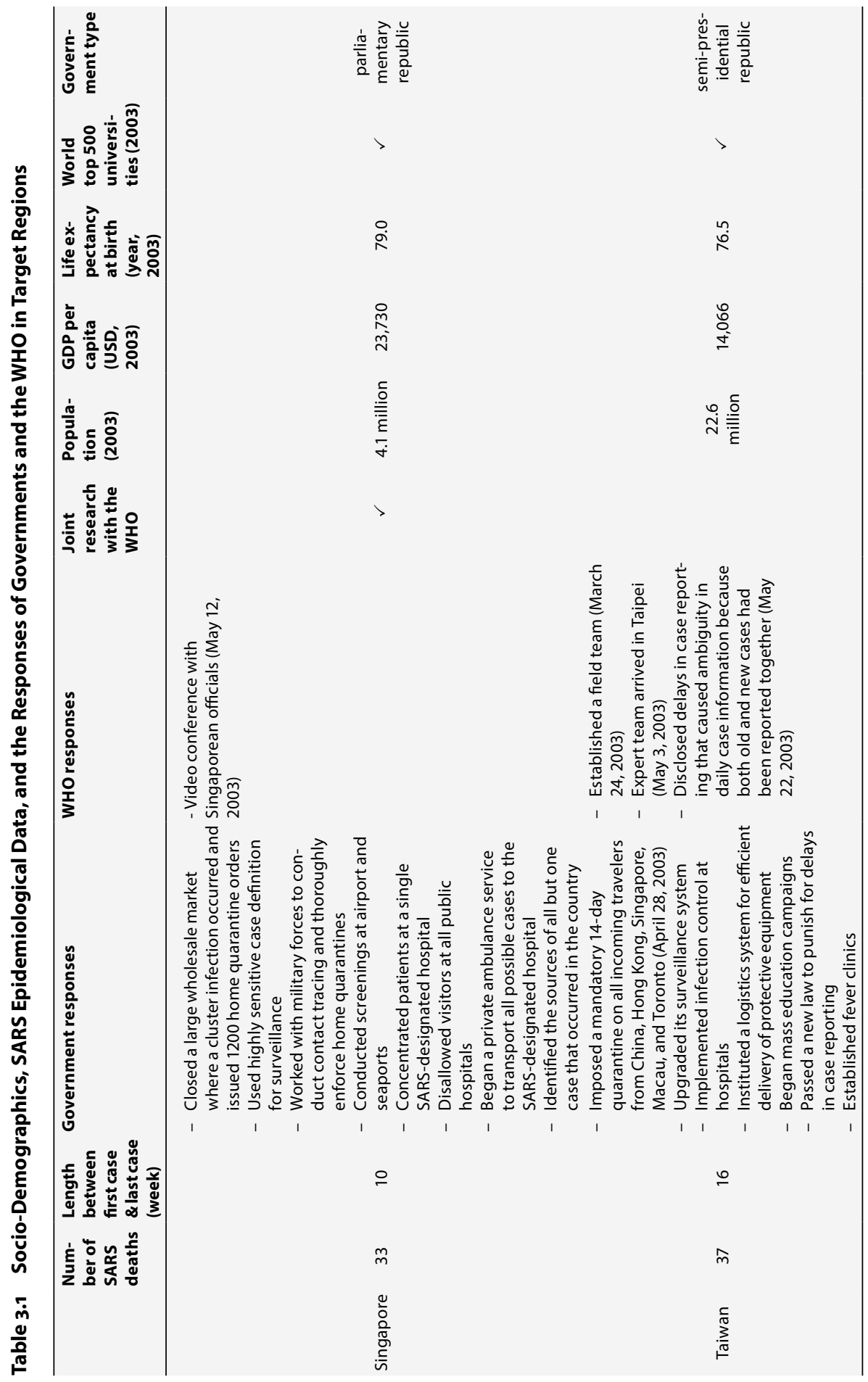


THE OUTBREAK OF INFECTIOUS DISEASE

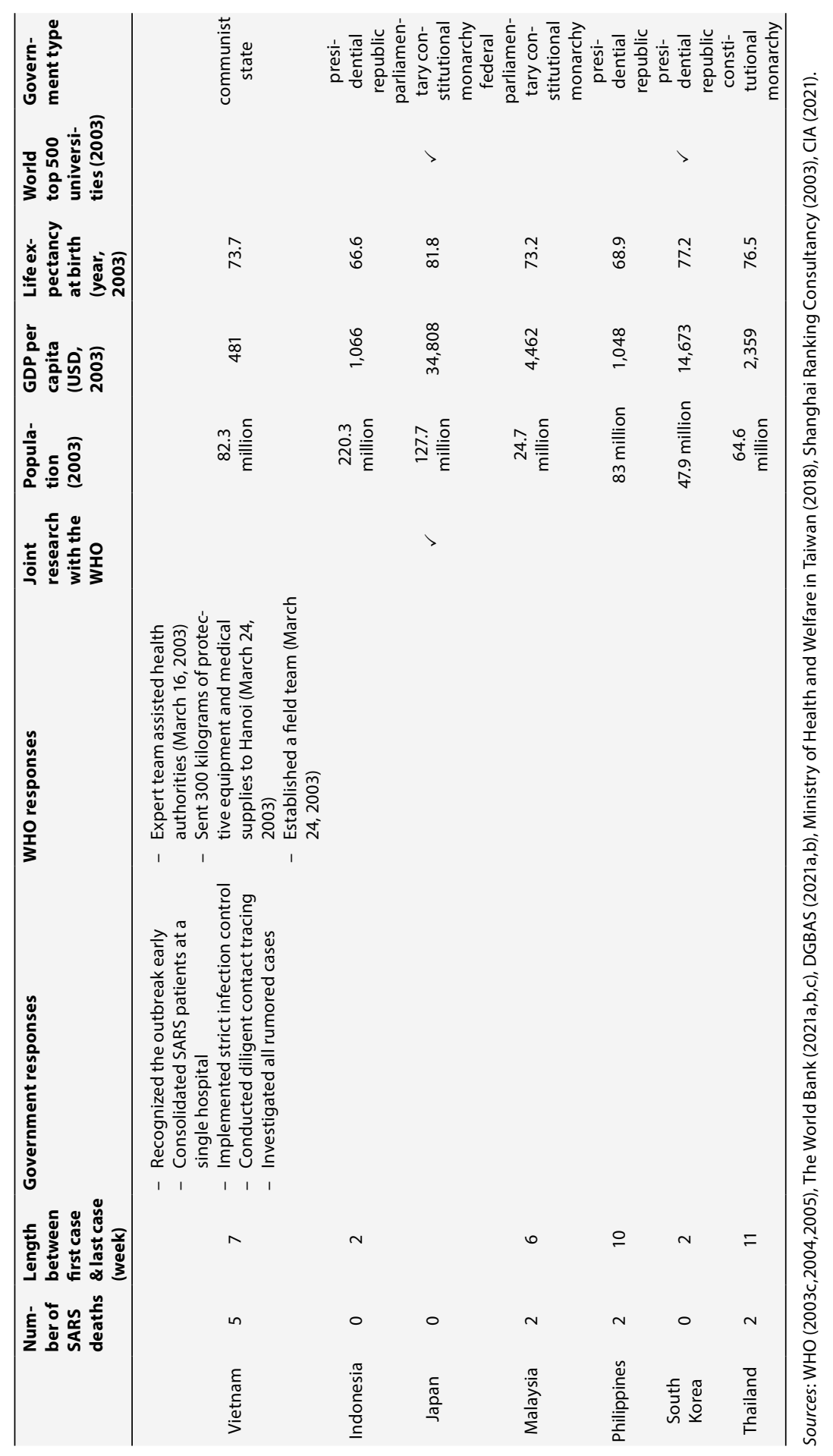


the WHO began investigations in mainland China in March and then in April reported on the infection situation, giving more specific numbers (WHO 2003a). For example, on 16 April the WHO warned that the number of people infected could be five times higher than the number reported by the Chinese government (WHO 2003b). On 7 May, the WHO gave an estimated case fatality rate, indicating that SARS mortality was quite high. The WHO eventually declared the end of the epidemic on 5 July 2003.

Table 3.1 summarizes the responses to SARS of different countries or regions, listing both SARS epidemiological data and the responses by governments and the WHO to the cases examined in this chapter. There are several notable points in the table.

First, the severity and duration of SARS infections varied among countries (see first and second columns). We categorized a group of countries and regions as being 'seriously affected', where these had many fatalities and a lengthy infection period. These places include China, Hong Kong, Singapore, Taiwan, and Vietnam. The remaining countries, Indonesia, Japan, Malaysia, the Philippines, South Korea, and Thailand, were categorized as a 'nonseriously affected' group.

Second, within the seriously affected group, the socio-demographics of the countries/regions are diverse; some possess good economic, health, and education conditions, while others do not. Political systems also differ within this group.

Third, measures taken by the governments varied among countries in the seriously affected group, especially regarding information dissemination. Singapore and Hong Kong seemed to have conveyed infection information to the public promptly, while Taiwan was criticized for a delay in case reporting. Although China was also criticized for concealing or not disclosing infection cases during the initial outbreak, the Chinese authorities changed this approach later on and provided the WHO with daily information about cases and deaths by province.

Fourth, the degree of collaboration with the WHO also differed among countries/regions. In the seriously affected group, for example, Vietnam's government collaborated closely with the WHO to control the outbreak. In contrast, the Chinese government only began working closely with the WHO and introduced a series of responses after the global alert in March.

There was variation in the amount of collaboration between these countries/regions and the WHO. The WHO issued a global alert about a newly identified coronavirus on 12 March 2003. At the same time, it also launched a collaborative centre research project on SARS. The purpose of this research network was to detect the SARS agent and to develop a diagnostic test. The laboratories that joined this research project shared 
samples and investigation findings in real time, and their findings were validated immediately in several laboratories ( $\mathrm{WHO}$ 2003c). The research network was comprised of eleven laboratories in nine countries.

Table 3.1 illustrates two important points. First, the research collaboration involved countries and regions that were both more severely and less severely affected by the SARS outbreak. A Japanese laboratory joined the project even though Japan was not severely hit by SARS. Several laboratories in China joined the project, while none in Vietnam did, although both countries were seriously affected.

Second, the research collaboration did not necessarily involve only economically and/or scientifically developed countries/regions. South Korea and Taiwan did not participate in the collaboration, despite having a comparatively high gross domestic product (GDP) per capita and highly ranked universities. Chinese institutes joined the project, although China's GDP per capita was relatively low in 2003 compared to other countries. The next part of this chapter presents the empirical strategy that we have used and describes the data we have analysed to study public levels of trust in government during the SARS epidemic.

\section{Methodology and Data}

This chapter addresses two research questions regarding the 2003 SARS epidemic:

1 Did the SARS epidemic lead to a deterioration in the public's trust in government in Asian countries?

2 Did research collaboration with the WHO mitigate the loss of social trust?

These questions were answered based on two kinds of empirical analysis. The first empirical analysis used the 'Difference in Differences' (DID) method. This takes advantage of the unexpected and sudden spread of SARS in early 2003 (November 2002-February 2003), and the large differences in infection status among Asian countries. To employ the DID method to quantify the impact of the epidemic on social trust, we used information about both SARS-affected and SARS-non-affected groups before and after the epidemic. SARS-affected countries and regions are defined as those that had local SARS transmission by the time the WHO issued its global SARS epidemic alert (WHO 2003d). As defined in the previous section, these include China, Hong Kong, Singapore, Taiwan, and Vietnam. Indonesia, Japan, Malaysia, the Philippines, South Korea, and Thailand are defined as SARS-non-affected. In a DID framework, the former is referred to as the 'treated' group and the latter as the 'control' group. 
We used data about East and Southeast Asia from the World Values Survey 1993-2014. ${ }^{1}$ We selected this sample period to balance the number of years before and after the 2003 epidemic. This survey directly asked respondents about their level of trust in government and collected respondents' personal characteristics. This allowed us to analyse the impact of the SARS outbreak on changes in trust levels, while eliminating differences caused by personal characteristics, such as age, socioeconomic conditions, medical environment, and lack of interest in politics. By tracking each country over multiple time frames, our analysis was also able to remove differences in trust in government caused by historical, cultural, and geographic circumstances, as well as the political system in the country/region. In other words, the analysis isolated and identified the impact of an infectious disease outbreak on public trust in government.

Level of trust, the dependent variable in this analysis, reflects individual trust in government. It was measured with the question: 'Could you tell me how much confidence you have in the government: is it a great deal of confidence, quite a lot of confidence, not very much confidence, or none at all?' Answers were recorded on a four-point scale, from $1=$ none, to $4=$ a great deal of confidence. Analysing the responses to this question, we examined whether the level of trust in government fell only in the treated countries/regions (or those labelled SARS-affected).

The second part of the analysis used a 'triple-difference' (DDD) method to examine how the impact of the epidemic on trust in government differed in countries with a WHO collaborating centre. Since decisions about the partnerships were made at the early stage of the SARS epidemic, we could examine whether becoming a member of the WHO joint research project mitigated the loss of trust in government.

\section{Results}

\section{Negative Effect of the SARS Epidemic on Trust}

Figure 3.1 shows the average level of trust in government. The black and striped bars show the average respondent's trust in the treatment and control

1 The World Values Survey (WVS) began in 1981 and consists of nationally representative samples of over 100 countries that use a common questionnaire (Inglehart et al. 2014). Many studies on social trust use WVS data (for example, see Knack and Keefer 1997, 1251; Mikucka et al. 2017, 1; Kentmen and Cin 2012, 971). 
Figure 3.1 Average level of trust in sample governments

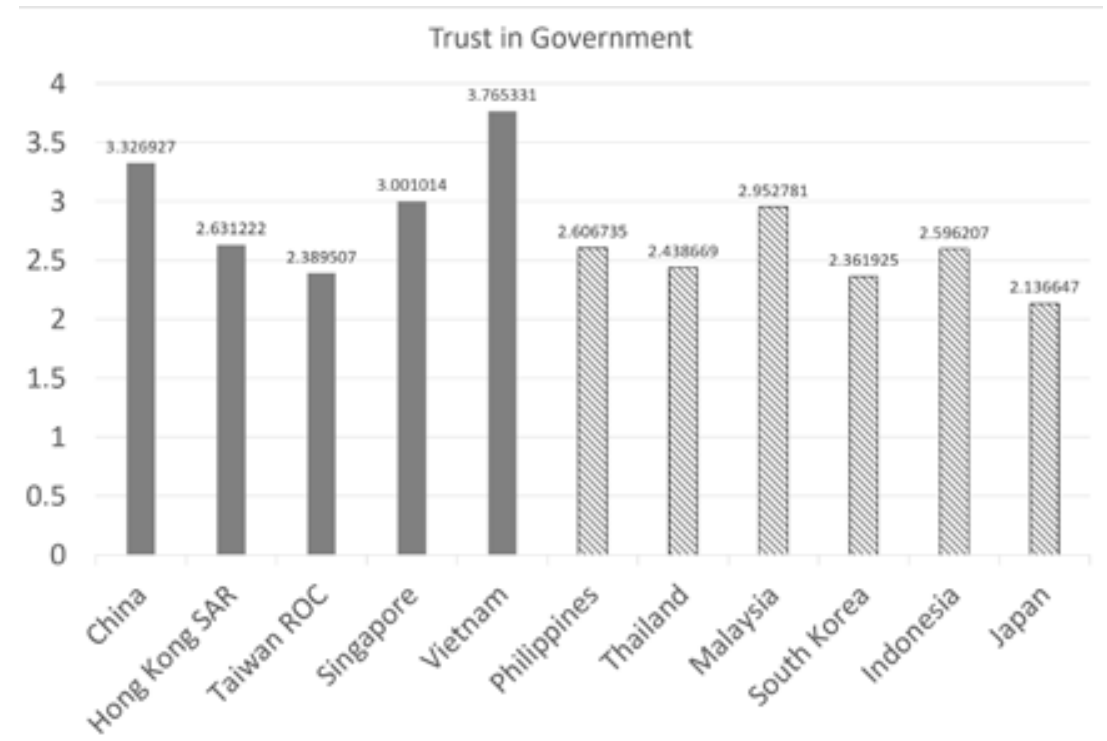

groups respectively. Figure 3.2 shows the average level of trust over time for the treatment and control groups. These figures show that the levels of trust in government were relatively high in the SARS-affected countries both before and after the outbreak. Low public trust, therefore, did not characterize SARS-affected countries. The striking feature in Figure 3.2 is a decline in trust only for the treatment group (or SARS-affected countries) from 1999-2002 to 2005-2008. ${ }^{2}$ The loss of public trust in government can be attributed to the SARS outbreak.

This drop was further confirmed by our empirical examination using 29,320 observations. The DID analysis showed a statistically significant drop of trust in government only in the SARS-affected countries (treatment group) after the outbreak. The results are robust. The negative coefficients remained significant even after changing the estimation specifications. ${ }^{3}$

2 The occurrence and reoccurrence of the SARS epidemic corresponds to the timeframes between the two mentioned periods, which suggests the existence of 'cut-off points' before and after the epidemic was declared and eventually considered over. This is taken into account in our DID estimation.

3 The estimation results using the 29,320 observations in sample countries are:

$S \hat{T} G_{i}=-0.268 S A R S \cdot$ Post $_{i}+0.786 S A R S_{i}+0.208$ Post $_{i}+4.814$

(0.021) (0.019) (0.013) (0.149)

Herein, is a measure of social trust in government of individual $i$; is a dummy variable indicating 
Figure 3.2 Average level of trust in the SARS-affected (treatment) and nonaffected (control) groups

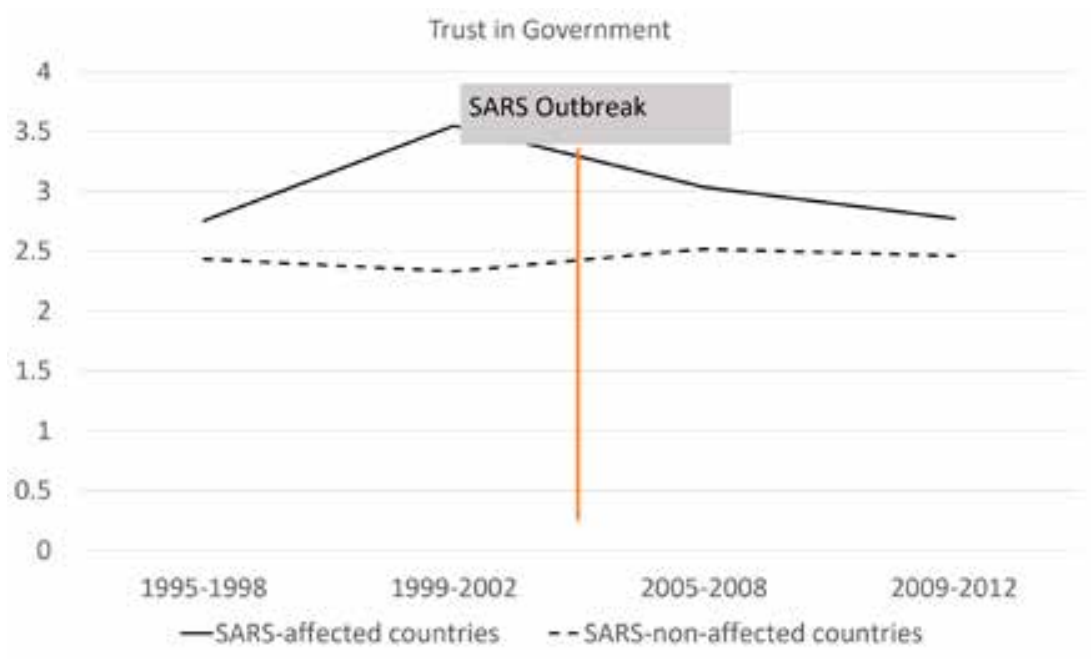

It is notable that people in the SARS-affected countries, compared with those in non-affected countries, tended to have higher public trust in government both before and after the SARS outbreak. Thus, the decrease in levels of trust found in the SARS-affected countries should not be attributed to country characteristics that existed even before the outbreak. It is also notable that there is an upward trend of public trust in government after 2003 in non-affected countries. As such, the drop in social trust after 2003 in the SARS-affected countries cannot be explained by a time trend. These highlight the negative impact of an infectious disease outbreak on trust in government: the loss of public trust in government was due to the epidemic.

What was the public attitude in general? We checked how the trust of members of the public in other people changed with the occurrence of SARS.

that a country was affected by SARS, which equals 1 if a respondent $i$ lives in a SARS-affected country and o otherwise; is a dummy variable indicating the period after the SARS epidemic, which equals 1 if a survey year was in or after 2003, and o otherwise. The coefficient on the focal interaction term of is significant at the $1 \%$ significance level. Although the results are not shown in the equation, the estimate also controls for individual characteristics, such as age, gender, marital status, education, employment status, income level, and country's economic and medical environments (e.g., per capita GDP and life expectancy at birth) in the country where individual $i$ lives, and country dummies. The country-level data are from the World Development Indicators (2020) and country-level indicators for Taiwan from Taiwan Health and Welfare Indicators (2018). The detailed results and descriptive statistics of the dataset are available upon request. 
To do this, we also used the DID methodology, but replaced public trust in government with trust in other people as the dependent variable. We found that social trust in people increased significantly in SARS-affected countries after the outbreak. This contrasts with the previous result on public trust in government. In other words, the spread of SARS reduced public trust in government, whereas it raised social trust in people. People may feel the need for social connectedness in times of serious disease outbreaks, so as to allay their fear of unpredictable threats.

One possible explanation for the negative effect of SARS on public trust in government is that people's anxiety increases because of a lack of reliable information. For example, during the SARS epidemic Taiwan was criticized for delaying case reporting until mid-May, as mentioned in the previous section.

\section{The Alleviating Effects of WHO Research Collaboration}

This section examines how research collaboration with the WHO affected the decline in public trust in government after the epidemic. The investigation, using a DID approach, found a statistically significant difference in the effect of the SARS outbreak on trust in government for those countries/ regions with and without research collaboration with the WHO. Specifically, the drop in public trust in government after the 2003 SARS outbreak was smaller in the countries hosting WHO collaborating centres. ${ }^{4}$

It might be argued that, rather than their participation in the WHO research collaboration, it was instead the presence of good research environments in these countries/regions that actually prevented people from losing their trust in government after the epidemic.

However, the findings of our study do not support this argument. First, people in well-developed societies with better health and educational environments are not likely to show higher trust in government. Second, the presence of a high-ranked university in a country (which can indicate a

4 Estimated results using the 29,320 observations in sample countries are:

$S \hat{T} G_{i}=-0.54 S A R S \cdot$ Post $_{i}+0.52$ SARS $\cdot$ Post $_{i} \cdot$ Collab $_{i}+0.77$ SARS $_{i}+0.22$ Post $_{i}$

(0.03) (0.05) (0.02) (0.02) (0.03)

-0.08 Collab $\cdot S A R S_{i}-0.12$ Collab $\cdot$ Post $_{i}+4.10$, $^{-}$

(0.04) (0.03) (0.15)

where Collab $_{i}$ is a dummy variable with the value 1 if respondent $i$ 's country has a research institute joining the WHO project network, and the value o otherwise. The equation includes control variables such as individual and country characteristics as well as country dummies, although the results are not reported here. The detailed results are available upon request. 
well-developed scientific environment) was not found to have a statistically significant mitigating effect on the loss of trust in government after the SARS epidemic. ${ }^{5}$ In other words, joining the WHO collaborative centre, and not simply having advanced research institutes, played a key role in mitigating the loss of trust in government after the SARS epidemic.

What explains this finding? There are two possible reasons. The first reason is what we have labelled as reputation effects. The WHO is widely recognized as the main UN agency responsible for disease control and mitigation. It thus has greater legitimacy to act in times of disease outbreaks. National governments would also gain legitimacy and public trust when officials can claim that they 'have worked closely with the WHO'.

The second reason is what we have labelled as information sharing effects. One of the main aims of setting up the WHO research collaboration on SARS was to share the outcomes of investigations of clinical samples from actual cases in real time (WHO 2003c). Daily assessments of research results were based on diagnostic tests conducted in member institutes. Results of laboratory diagnostic tests are important for governments to understand the pathways of transmission and implement preventive measures. Laboratory results are equally crucial in convincing people that they must follow measures to stop the spread of diseases.

Importantly, our findings suggest that reputation effects cannot consistently explain the mitigating effect of WHO research collaboration on the loss of trust in government in the wake of the SARS epidemic. Cooperation between national governments and the WHO can be attained in many ways other than research collaboration. For example, as mentioned in the previous section, Vietnam had a good cooperative relationship with the WHO during the SARS outbreak. Vietnam, however, did not have any domestic institutes that joined a WHO collaborative research project. Because loss of trust in government was mitigated by research collaboration with the WHO specifically, rather than by a general cooperation with the WHO, in Vietnam's case there was no mitigating effect of its more general cooperation with the WHO. The data therefore do not suggest the existence of reputation effects for Vietnam.

However, information sharing effects also do not thoroughly explain our findings. The results indicate that rather than the existence of top scientific universities, the existence of the WHO research collaboration made the

5 High-ranked universities are those ranked in the top 500 (based on Academic Ranking of World Universities published in 2003). For estimations, we used a dummy variable taking the value 1 if a country has at least one high-ranked university, and o otherwise. 
difference in mitigating loss of trust after the epidemic. Notably, there are several important aspects of information assessment. Information should be quickly transmitted, scientifically accurate, and credible. Information satisfying these aspects cannot be made available by domestic researchers if they cannot access patients' medical reports and if the country does not experience the outbreak. Furthermore, transmission of credible information cannot be guaranteed if the general public does not trust domestic research groups/institutes.

As such, information sharing under multilateral collaboration implemented by a third party that can be trusted is beneficial. A third party, such as the WHO, can call upon countries to join a research collaboration. The SARS-affected countries which engaged in WHO research collaboration successfully avoided epidemic-driven declines in trust in government after the pandemic, because they could obtain rapid, scientifically accurate, and credible information from the research network.

What are the implications of this for the COVID-19 pandemic? Our findings suggested that quick transmission of scientifically credible information by government collaboration with a third party such as the WHO would have a mitigating effect on the loss of trust in government. During the COVID-19 pandemic, the WHO has been less successful in providing a rapid response to preventing the spread of disease based on academically trustworthy findings.

During the SARS epidemic, the WHO international team of experts began investigations in the Chinese province of Guangdong on 3 April 2003 (three weeks after the WHO issued the global epidemic alert). The WHO then presented its official interim report on 9 April 2003 (WHO, 2003b). In contrast, when COVID-19 emerged in 2020, the WHO international team began investigations in the Chinese city of Wuhan on 29 January 2021 (one year after the WHO declared the virus a Public Health Emergency of International Concern). It then presented its official report on 30 March 2021 (WHO, 2021).

Scientifically credible information was not transmitted to the public in the early stages of the spread of COVID-19. Had there been information transmission through collaboration between countries and the WHO, this could have contributed to maintaining public trust in government, and helped governments to control the spread of COVID-19. Impeded collaboration can be harmful for both governments and the WHO. While national governments lose public trust as a result of impeded collaboration, the WHO is less able to effectively fulfil its role of helping to stop an outbreak turning into a pandemic. 


\section{Conclusion}

This chapter has examined how the 2003 SARS epidemic affected public trust in government, and how this negative effect was mitigated by collaboration with the WHO. The analysis was based on the DID method, which takes advantage of the unexpected, sudden spread of SARS in early 2003, and the large differences in infection rates in Asian countries. This analysis used data for East and Southeast Asia from the World Values Survey 1993-2014, which included information on respondents' levels of trust in their respective governments, their personal attributes, and the countries or regions in which they resided. This allowed us to identify the impact of an infectious disease outbreak on public trust in government, eliminating differences caused by personal attributes, and countries' historical, cultural, and geographic circumstances.

The analysis showed that the 2003 SARS outbreak reduced people's trust in governments in Asian countries. Importantly, this does not mean that public trust in government was initially low in countries with high infection levels, or that public trust fell simply because of the severity of the SARS outbreak. This is neither consistent with a general uptrend in public trust levels, nor with the uptrend in social trust in people such as neighbours. Thus, it is possible to conclude that the outbreak of an infectious diseases damaged the level of trust in government. Overall, there was a clear effect of the SARS outbreak on the loss of public trust in government among Asian countries.

The analysis further showed that this loss was mitigated in the countries with research institutes participating in WHO research collaboration. The results highlight the importance of scientific collaboration with the WHO on health-related issues. Joint research with a third party, such as the WHO, enables swift dissemination of credible scientific information, and facilitates the promotion of appropriate preventive measures among the general public. Information sharing through collaboration may also allow national governments to implement effective policies. While many Asian governments lost public trust due to the SARS outbreak, prompt dissemination of accurate evidence-based information may have led to an increase in trust in other people in society.

By cooperating with international organizations such as the WHO to provide objective scientific evidence during the spread of an infectious disease, governments can effectively encourage people to take necessary action without losing public trust. 


\section{References}

Acemoglu, Daron, Ali Cheema, Asim I. Khwaja, and James A. Robinson. 2020. 'Trust in State and Non-State Actors: Evidence from Dispute Resolution in Pakistan.' Journal of Political Economy vol. 128, no. 8: 3090-3147. https://doi. org/10.1086/707765.

Armingeon, Klaus, and Kai Guthmann. 2014. 'Democracy in Crisis? The Declining Support for National Democracy in European Countries, 2007-2011.' European Journal of Political Research vol. 53, no. 3: 423-442. https://doi. org/10.1111/1475-6765.12046.

Bangerter, Adrian, Franciska Krings, Audrey Mouton, Ingrid Gilles, Eva Green, and Alain Clémence. 2012. 'Longitudinal Investigation of Public Trust in Institutions Relative to the $2009 \mathrm{H} \mathrm{N}_{1}$ Pandemic in Switzerland.' PLoS One vol. 7, no. 11: 1-8. https://doi.org/10.1371/journal.pone.0049806.

Central Intelligence Agency. 2021. 'The World Factbook East Asia/Southeast Asia.' Accessed 8 February 2021. https://www.cia.gov/the-world-factbook/ east-asia-southeast-asia/.

Freimuth, Vicki S., Don Musa, Karen Hilyard, Sandra C. Quinn, and Kevin Kim. 2014. 'Trust During the Early Stages of the 2009 H1N1 Pandemic.' Journal of Health Communication vol. 19, no. 3: 321-339.

Inglehart, R., C. Haerpfer, A. Moreno, C. Welzel, K. Kizilova, J. Diez-Medrano, M. Lagos, P. Norris, E. Ponarin and B. Puranen (eds.). 2014. 'World Values Survey: All Rounds - Country-Pooled Datafile Version.' Accessed 8 February 2021. https:// www.worldvaluessurvey.org/WVSDocumentationWVL.jsp.

Kentmen Cin, Cigdem. 2012. 'Blaming the Government for Environmental Problems: A Multilevel and Cross-National Analysis of the Relationship between Trust in Government and Local and Global Environmental Concerns.' Environment and Behavior vol. 45, no. 8: 971-992.

Knack, Stephen, and Philip Keefer. 1997. 'Does Social Capital Have an Economic Payoff? A Cross-Country Investigation.' The Quarterly Journal of Economics vol. 112, no. 4: 1251-1288.

Kroknes, Veronika, Tor Georg Jakobsen, Lisa-Marie Grønning. 2015. 'Economic Performance and Political Trust: The Impact of the Financial Crisis on European Citizens.' European Societies vol. 17, no. 5: 700-723.

Kye, Bongoh, and Sun-Jae Hwang. 2020. 'Social Trust in the Midst of Pandemic Crisis: Implications from COVID-19 of South Korea.' Research in Social Stratification and Mobility vol. 68: 100523.

Lazarev, Egor, Anton Sobolev, Irina Soboleva, and Boris Sokolov. 2014. 'Trial by Fire: A Natural Disaster's Impact on Support for the Authorities in Rural Russia.' World Politics vol. 66, no. 4: 641-668. 
Mikucka, Mickuka, Francesco Sarracino, and Joshua K. Dubrow. 2017. 'When Does Economic Growth Improve Life Satisfaction? Multilevel Analysis of the Roles of Social Trust and Income Inequality in 46 Countries, 1981-2012.' World Development vol. 93: 447-459.

Nicholls, Keith, and Picou, J. Steven 2013. 'The Impact of Hurricane Katrina on Trust in Government.' Social Science Quarterly vol. 4, no. 2: 344-361.

Shanghai Ranking Consultancy. 2003. 'Academic Ranking of World Universities.' Accessed 8 February 2021. http://www.shanghairanking.com/ARWU2003.html. Sibley, Chris G., Lara M. Greaves, Nicole Satherley, Marc S. Wilson, Nickola C. Overall, Carol H. Lee, and Carla A. Houkamau. 2020. 'Effects of the COVID-19 Pandemic and Nationwide Lockdown on Trust, Attitudes toward Government, and Well-being.' American Psychologist vol. 75, no. 5: 618-630.

Van der Weerd, Willemien, Danielle R. Timmermans, Desiree J. Beaujean, Juriaane Oudhoff, and Jim E van Steenbergen 2011. 'Monitoring the Level of Government Trust, Risk Perception and Intention of the General Public to Adopt Protective Measures during the Influenza A ( $\left.\mathrm{H}_{1} \mathrm{~N}_{1}\right)$ Pandemic in the Netherlands.' BMC Public Health vol. 11, no. 575:1-12.

Ministry of Health and Welfare in Taiwan. 2018. '2014 Health and Welfare Indicators.' 19 September. Accessed 8 February 2021. https://www.mohw.gov.tw/lp-134-2.html. Directorate-General of Budget, Accounting and Statistics (DGBAS). 2021a. 'Total Population.' 28 January. Accessed 8 February 2021. https://eng.stat.gov.tw/point. asp?index $=9$.

—. 2021b. 'Per Capita GDP (US dollars).' 28 January. Accessed 8 February 2021. https://eng.stat.gov.tw/point.asp?index=1.

The World Bank. 2020. 'World Development Indicators.' 16 September. Accessed 8 February 2021. https://databank.worldbank.org/source/ world-development-indicators.

—. 2021a. 'Population, Total.' 28 January. Accessed 8 February 2021. https://data. worldbank.org/indicator/SP.POP.TOTL.

—. 2021b. 'GDP per Capita (current US\$).' 28 January. Accessed 8 February 2021. https://data.worldbank.org/indicator/NY.GDP.PCAP.CD.

-. 2021c. 'Life Expectancy at Birth, Total (years).' 28 January. Accessed 8 February 2021. https://data.worldbank.org/indicator/SP.DYN.LEoo.IN.

The World Health Organization (WHO). 2003a. 'Severe Acute Respiratory Syndrome (SARS): Status of the Outbreak and Lessons for the Immediate Future.' Accessed 8 February 2021. https://www.who.int/csr/media/sars_wha.pdf.

- 2003b. 'Update 95 - SARS: Chronology of a Serial Killer.' Accessed 8 February 2021. https://www.who.int/csr/don/2003_07_04/en/. 
-. 2003c. 'WHO Collaborative Multi-Centre Research Project on Severe Acute Respiratory Syndrome (SARS) Diagnosis.' Accessed 8 February 2021 https:// www.who.int/csr/sars/project/en/.

- 2003 d. 'Cumulative Number of Reported Cases (SARS).' Accessed 8 February 2021. https://www.who.int/csr/sars/country/2003_03_24/en/.

—. 2004. 'Situation Updates - SARS.' Accessed 8 February 2021. https://www.who. int/csr/sars/archive/en/.

- 2005. 'Summary of Probable SARS Cases with Onset of Illness from 1 November 2002 to 31 July 2003.' Accessed 8 February 2021. https://www.who.int/ publications/m/item/summary-of-probable-sars-cases-with-onset-of-illnessfrom-1-november-2002-to-31-july-2003.

-. 2021. 'WHO-Convened Global Study of Origins of SARS-CoV-2: China Part.' Accessed 7 April 2021. https://www.who.int/publications/i/item/ who-convened-global-study-of-origins-of-sars-cov-2-china-part.

\section{About the Authors}

Yumi ISHIKAWA is a PhD student at the Osaka School of International Public Policy (OSIPP), Osaka University. Her interest is primarily in public health. She completed her Master's at OSIPP and a MSc in Global Health at King's College London. She has research experience at the WHO headquarters (2017) and WHO country office in Cambodia (UN Volunteer, 2019-2020).

Miki KOHARA is a professor at Osaka School of International Public Policy, Osaka University. Her research field is Labour Economics and Applied Econometrics. She has a special interest in family behaviours of labour supply, consumption and health-preventive-behaviours. She is also interested in the evaluation of health and labour policies. 



\section{PART II}

The Future of Global Health Governance in Asia 



\title{
4 China and the World Health Organization
}

\author{
Not an Easy Road for Either
}

Xue GONG and Xirui LI

\begin{abstract}
The role of the World Health Organization (WHO) as a global health agency has come under mounting pressure since the start of the COVID-19 pandemic. Many have linked the WHO's negligence and mistakes to the strong influence of the People's Republic of China (PRC) over the organization. However, this chapter argues that China's leadership potential in the WHO has been constrained by three factors: its insignificant contribution to the WHO compared to the traditional donors, its illiberal and fragmented domestic governance structures, and its assertive health diplomacy. Despite the US withdrawal from the WHO under the Trump administration, it would be incorrect to assume that China currently has sufficient resources to take on a leadership role in the WHO.
\end{abstract}

Keywords: China (People's Republic of China), COVID-19, global health governance, World Health Organization, China-United States relations, multilateral institutions

\section{Introduction}

Since the outbreak of the COVID-19 pandemic in China on 31 December 2019 (World Health Organization 2020), the WHO has been thrust into the international spotlight. Governments across the world have criticized the organization for its handling of the pandemic. The WHO's slow response and heavy reliance on the Chinese authorities has drawn sharp criticism,

Van der Veere, Anoma P., Florian Schneider, and Catherine Yuk-ping Lo (eds), Public Health in Asia during the COVID-19 Pandemic: Global Health Governance, Migrant Labour, and International Health Crises. Amsterdam, Amsterdam University Press 2022 DOI: 10.5117/9789463720977_CHO4 
particularly from the US. One accusation has been that the WHO has become an accomplice of the People's Republic of China (PRC) in handling the global health crisis. After the WHO's Director-General lauded the PRC's 'speed, scale and efficiency' (Pilling 2020) in reacting to the spread of COVID-19, many American think tanks and media outlets expressed their concern that the organization was 'bowing to China' (Schaefer 2020). The WHO was accused of 'acting too slowly' (Hernández 2020), of being 'fully controlled by China' (Archyde 2020), and was seen as 'misleading the world' (Berger et al. 2020). The then US president Donald Trump initially threatened to cut US funding and eventually declared a formal withdrawal from the organization. In contrast, Chinese president Xi Jinping gave high-profile opening remarks at the WHO annual assembly in May 2020, reiterating the country's support for the organization. Xi also pledged to donate another USD $\$ 2$ billion to help other countries fight against the virus in the next two years (Xi 2020).

Against this backdrop, this chapter asks: Is China a leader in global health governance? And is China able to overshadow the US's global leadership? Although it has been argued that China's fast response to the domestic health crisis may indicate a change of international order (Campbell and Doshi 2020), this chapter argues that China's leadership potential in the WHO has been constrained by three factors: its insignificant contribution in the WHO compared to the traditional donors; its illiberal and fragmented domestic governance structures; and its assertive health diplomacy. This chapter also proposes that it is misleading to argue China's influence on the organization is the only factor that explains the WHO's missteps in handling the crisis.

The chapter is organized as follows: the next section discusses China's role in the WHO and assesses China's domestic governance capabilities. Following this, there is a discussion about the impact of China's health diplomacy.

\section{China's Role in Global Health Governance and the WHO}

For the past few decades, China's health governance capability has been sustained by an architecture established by the US (Huang 2015). With its ascendancy, China has been increasing its level of participation in, and engagement with, existing multilateral institutions, while also building new institutions. For instance, in 2017 China began promoting its Health Silk Road (HSR) within the WHO. China also established the Global Health Drug Discovery Institute, a partnership with the Gates Foundation that has 
Figure 4.1 Number of Statements Submitted to the WHA by China, the EU, and the US

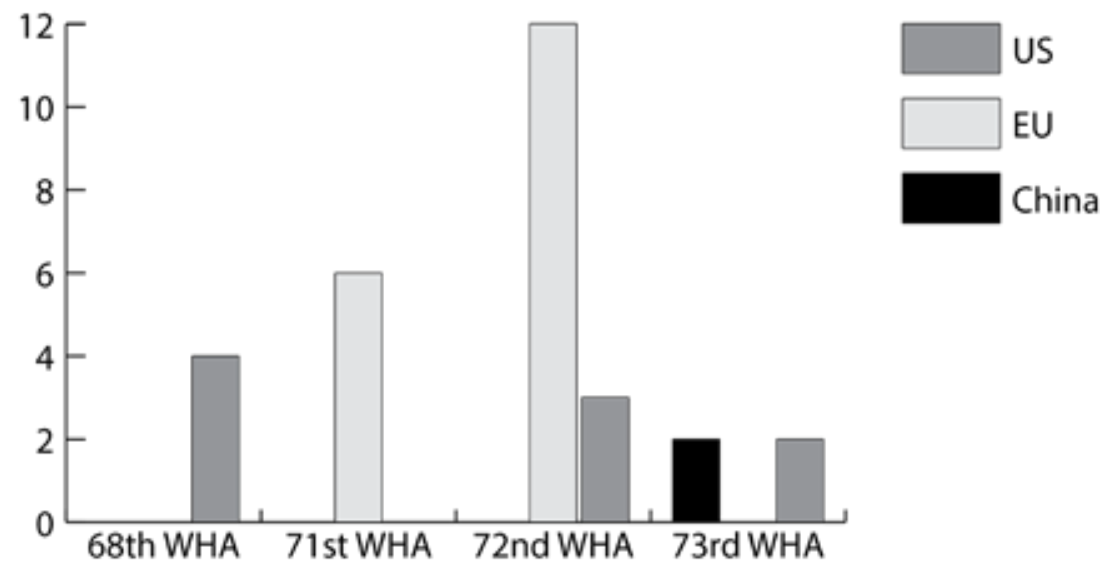

* The Archives of the WHA only show statements submitted by member states in the $68^{\text {th }}, 71^{\text {st }}$, $72^{\text {nd }}$ and $73^{\text {rd }}$ WHA;

* Figure 4.1 shows only the number of statements the EU made collectively. EU member states submitted individual statements in the $68^{\text {th }}$ and $73^{\text {rd }}$ WHA, while they submitted statements collectively in the $71^{\text {st }}$ and $72^{\text {nd }}$ WHA.

Source: Authors' summary based on WHO website (World Health Organization 2020a).

the aim of fighting epidemics. China has extended its influence through different regional mechanisms, such as the China-Africa Health Ministers Conference and the BRICS Health Ministers Conference. Given China's increased engagement in global health, some have argued that global health governance will come under China's leadership (Huang 2017). But is this likely?

To assess the extent of China's leadership role in the WHO, this chapter examines China's influence in three aspects of governance: agenda setting, funding, and expertise. The assessment criteria are not exhaustive, but they are frequently overlooked or misunderstood by international society. Besides, they can also give an overview of China's influence in the international organization.

\section{Agenda Setting}

First, the depth and scope of China's participation in the WHO are limited. As shown in Figure 4.1, China did not make any statements in the $68^{\text {th }}$, $71^{\text {st }}$, and $72^{\text {nd }}$ meetings of the World Health Assembly (WHA), the annual 
Figure 4.2 WHO Assessed Contributions by Countries (Updated until Q2 2020)

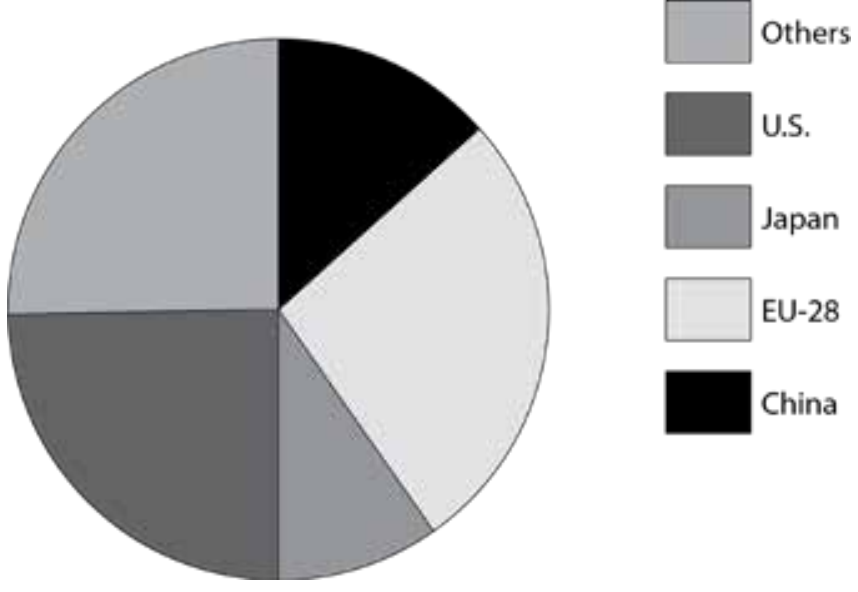

Source: Authors' calculation based on the data from WHO website (World Health Organization 2020b).

decision-making meeting held by the WHO. ${ }^{1}$ In contrast, the United States and European Union (EU) both submitted statements during these meetings. It was only at the $73^{\text {rd }}$ WHA in 2020 that China submitted two statements: one on COVID-19 and the other on the One-China policy. ${ }^{2}$

\section{Funding}

According to the WHO, in 2020 the majority of its funding came from specified voluntary contributions ( $55.62 \%$ of total funding) and projected funding (27.2\% of total funding), while assessed contributions accounted for $14.26 \%$. Within the assessed contributions, the US together with the EU and Japan provided over $60 \%$ of funding; the Chinese contribution of US $\$ 129,287,000$ (or 13.5\% of total assessed contributions) is comparatively insignificant (see Figure 4.2). Similarly, Figures 4.3 and 4.4, which respectively show voluntary contributions and projected funding, also indicate that most of the donors are from the West while China is a relatively insignificant player.

1 The WHA is the annual meeting of the WHO member states. Members are 'to determine the policies of the Organization, appoint the Director-General, supervise financial policies, and review and approve the proposed programme budget (World Health Organization a).'

2 The One-China policy states that 'Taiwan is an inalienable part of China' and holds there is only one China (Taiwan Affairs Office and the Information Office of the State Council 20oo). 
Figure 4.3 WHO Specified Voluntary Funding by Parties (Updated until Q2 2020)
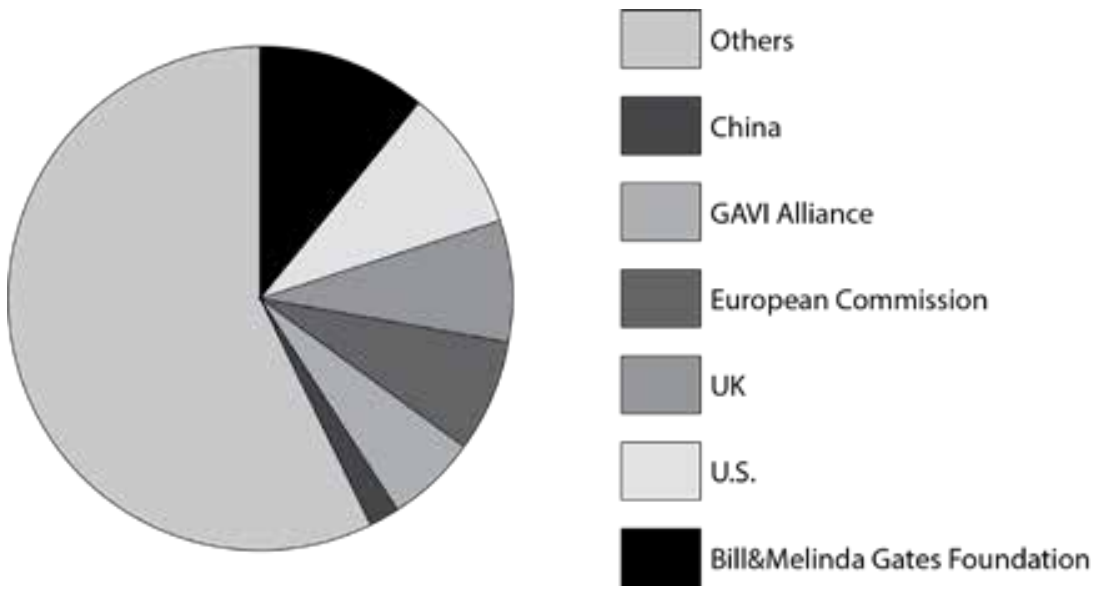

Source: Authors' calculation based on the data from WHO website (World Health Organization 2020b).

Although China's contribution to the organization has grown in the past few years, the increase is largely within the assessed contributions while over half the WHO funding comes from specified voluntary contributions. When all the funding contributions are put together (see Figures 4.3-4.5), China's share is extremely small compared to the contributions being made by Western state donors, or those made by private donors such as the Bill \& Melinda Gates Foundation.

\section{Expertise}

China's influence over the WHO can be measured through the participation of its health and medical experts with the organization. The majority of WHO staff are US nationals (Glassman and Datema 2020) who play key roles in the WHO's operations as members of the WHO advisory committee. Apart from the former Director-General of the WHO, Margaret Chan, who is of Hong Kong origin and who helped to promote Traditional Chinese Medicine, the role of Chinese experts in the organization has been minimal when compared to their US counterparts.

China's limited contribution is also apparent in its involvement with the WHO collaborating centres (institutions such as research institutes and universities designated by the WHO Director-General to carry out activities in support of the organization). As of September 2020, of the 844 
Figure 4.4 WHO Projected Funding by Parties (Updated until Q2 2020)
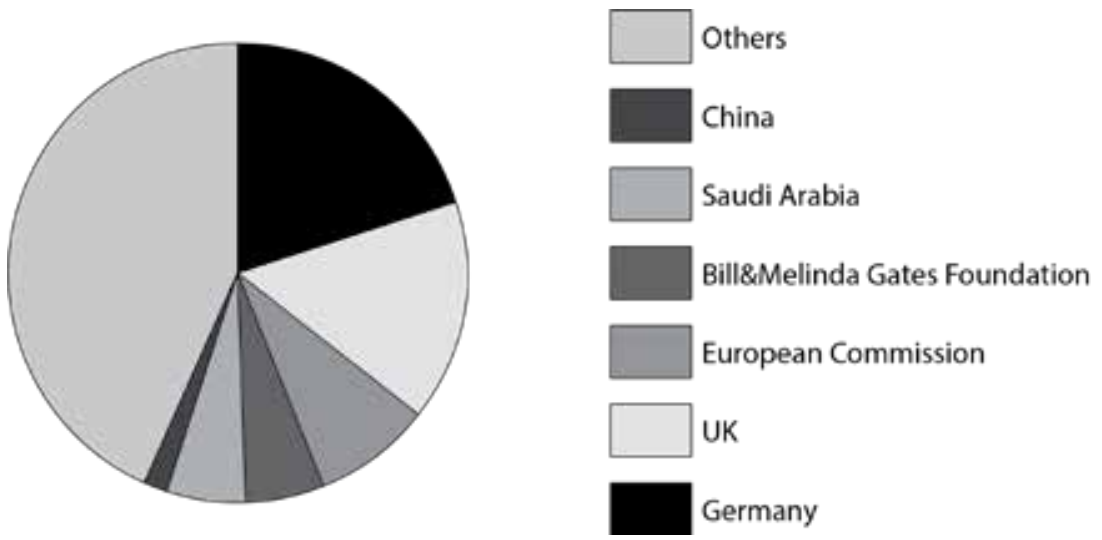

Source: Authors' calculation based on the data from WHO website (World Health Organization 2020b).

WHO collaborating centres worldwide, 181 were located in the US and 130 in China. When comparing the width and depth of collaborating centres, those in the US are more specialized (see Figure 4.5). For instance, China does not have any WHO collaborating centres for water and sanitation, aging, cancer, and cholera, while the US has at least one centre for each of these categories.

The above analysis corresponds to existing research that has shown that the WHO is heavily dependent on major donors (Gostin 2015). As described above, China's donation to the organization is comparatively low. Constrained by its structural limits, the WHO has to walk a fine line between the need for cooperation and information-sharing from member states and the need to hold them accountable for mistakes. As such, WHO officials tend to use diplomacy instead of confrontation in order to 'coax more information' and foster cooperation (Associated Press 2020). The WHO's overdependence on funding from major donors constrains its enforcement and policing powers. In other words, the WHO's mishandling of the crisis is not a direct result of China's influence but is largely because of its organizational constraints.

\section{Domestic Constraints}

China's influence in global health governance is also limited by its deficient domestic health governance. Since the 1980s, China's healthcare system has undergone several reforms (Xinhuanet 2019) and has made progress in 
Figure 4.5 WHO Collaborating Centres in the US and China by Subjects (Pending and Active)
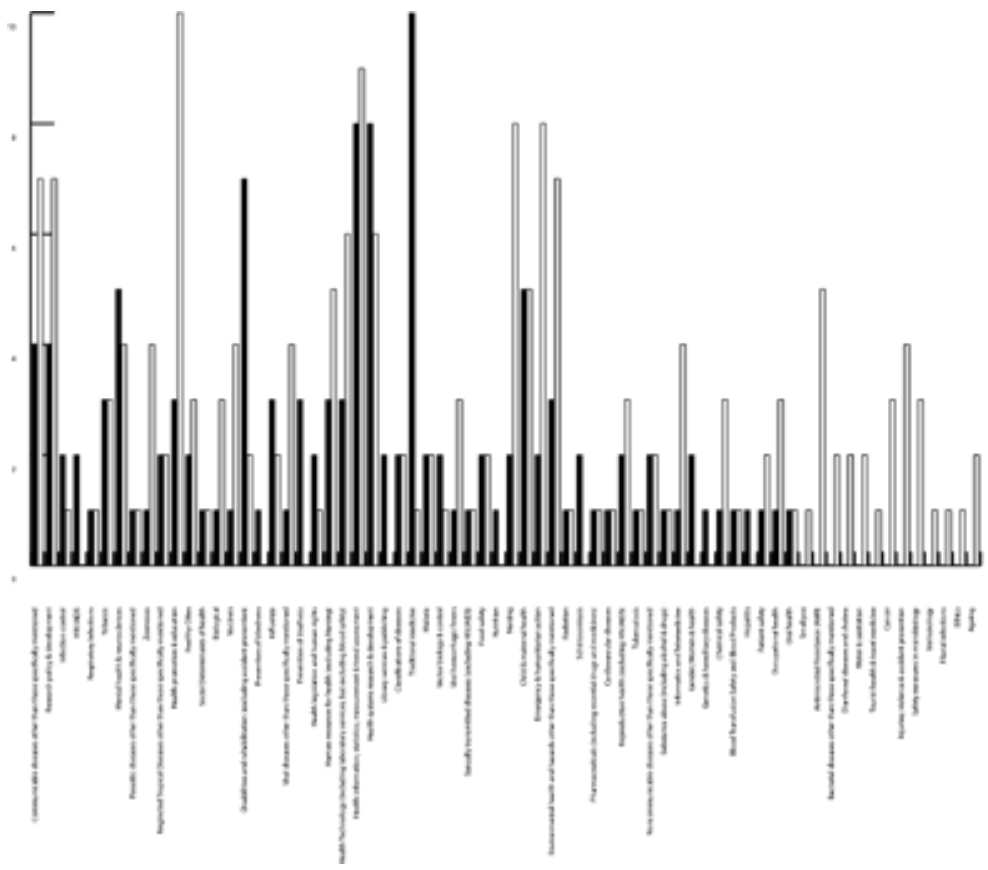

Source: Authors' drawing based on WHO Collaborating Centres Global Database. Accessed 19 September 2020 (World Health Organization 2020c).

improving overall health conditions domestically (World Bank 2018). Despite these achievements, China still faces numerous challenges in domestic healthcare. For instance, healthcare provisions in China are quite imbalanced and such imbalance continues to worsen. Leng (2019) reports that, in 2019, over 2300 top-tier public hospitals could barely meet the demand for medical care services, while almost 950,000 lower-tier healthcare institutions faced difficulties in attracting patients.

More tellingly, the medical system is fragmented (Yip and Hsian 2008), which further weakens the government's capacity in supervision and policy coordination (Ramesh, Wu, and He 2014). For instance, in the Twelfth FiveYear Plan, health informatization (using digital technology to facilitate and improve on public access to data and information) was recognized as a crucial part of medical reform in China (Li et al. 2019). However, fragmented management hinders data consolidation. For example, electronic health records are managed by the National Health Commission (NHC), while data 
about insurance claims is managed by the National Healthcare Security Administration (Yip et al. 2019). The lack of information sharing between these two separate entities makes effective coordination hard to achieve.

Moreover, the persistent central-local tensions in Chinese politics have significantly limited China's preparedness for public crises. Local governments tend to be defensive when handling public crises to secure their legitimacy. As a result, maintaining stability (weiwen 维稳) has become a means of conflict and crisis resolution in China (Benney 2016). In times of crisis, both local and central governments tend to cover up problems and maintain a low profile. It was for this reason that Li Wenliang, a doctor who was one of the first to raise the alarm about signs of a new type of coronavirus, was arrested for sharing information with colleagues. The Wuhan government then attempted to secretly report the disease outbreak to the central government.

The fragmented bureaucracy has posed a significant challenge to China's capacity for timely response. At the national level, the Chinese Centre for Disease Control and Prevention (CCDC), which is responsible for handling national health crises, is under the leadership of the National Health Commission (NHC). ${ }^{3}$ When COVID-19 broke out in Wuhan, local officials reportedly withheld information for the purpose of maintaining stability (Wong, Barnes, and Kanno-Youngs 2020). The Wuhan CDC first reported the outbreak to the Wuhan Municipal Health Commission, under the Wuhan municipal government, instead of reporting the cases to the national-level CDC. In this way, fragmentation leads to delays in information sharing and reveals central-local frictions. The former mayor of Wuhan, Zhou Xianwang, indicated that the release of information was delayed because the municipallevel officials did not obtain authorization from Beijing, implicitly shifting the blame to the central government (BBC News Chinese 2020).

This domestic political factor, namely fragmented bureaucracy, in China appear to result in the slow release of information about the pandemic. China has become more transparent in disease control and prevention since the SARS crisis in 2003. Nevertheless, the outbreaks of $\mathrm{H}_{1} \mathrm{~N}_{1}$ in 2009, and of African swine fever in 2019, reveal that China continues to misrepresent or cover up disease outbreaks. Zhong Nanshan, a well-known Chinese expert who participated in the fight against SARS in 2003 and who is currently head of the High-Level Expert Group of the NHC, pointed out that: 'CDC in countries like the US can directly report to the central government instead of reporting

3 There are multiple vertical lines of authority within these two agencies. For example, at the provincial level there is usually a provincial CDC and a provincial Health Commission in place. 
the issues level by level [...] in China, what the CDC can do is to report to the local government and nothing else' (Zhang 2020, author's translation).

\section{Assertive Health Diplomacy}

Because of China's early missteps and cover-ups, it has come under the scrutiny of international society. Australia, the US, and other countries have called for an independent probe into the outbreak (Dziedzic 2020). Several US senators even sought an investigation into the WHO's role in the global health crisis (Tsirkin, Hunt, and Haley 2020).

Facing these accusations, the PRC government has attempted to reshape narratives about the origins of the virus (Erlanger 2020) and its approach to handling the health crisis. In early February 2020, with the domestic containment of the virus proving effective, China began to provide international assistance. The Chinese government lauded the quantity of its medical support for Europe, Africa, and other parts of the world. In early March, China announced a US\$20 million donation to the WHO (CGTN 2020) and also pledged another US\$30 million (Ministry of Foreign Affairs 2020). In May 2020, President Xi (2020) made a speech at the opening ceremony of the 73rd World Health Assembly (WHA), where he announced US\$2 billion assistance to support COVID-19 responses and economic and social development in affected countries over the next two years. In the same speech, Xi also claimed that China would assist in building the Africa Centre for Disease Control (CDC) headquarters and make the vaccine a global public good once it was ready (ibid.).

To mitigate concerns over its early missteps and cover-ups and to redeem its reputation on the international stage, China launched a series of public diplomacy campaigns, contrasting its own response to COVID-19 with the responses of the US and several European nations (The Straits Times 2020). The Chinese leadership instructed diplomats to publicize China's generosity and praise the Chinese approach in handling the crisis, seeking to tell a good story of its experience with the hope of getting support and understanding (Embassy of People's Republic of China in the United Kingdom 2020).

However, many have suggested that China's attempts to enhance its image by reshaping the narrative have been seriously undermined by its assertive and provocative diplomacy, which has been labelled by some as 'wolf warrior' diplomacy (Zhao 2020). Since March 2020, the coercions and threats made by aggressive Chinese diplomats, together with the strident defence of China's image by online Chinese nationalists, have triggered 
outcries in Thailand, Australia, and elsewhere. For example, Cheng Jingye, the Chinese Ambassador to Australia, threatened to use economic coercion to counter Australia's call for an independent review into the origins and spread of the coronavirus in China. It has also been reported in the media that, when providing medical assistance to other countries, the Chinese side demanded that recipients officially recognize this assistance (Erlanger 2020). These anecdotes demonstrate the growing global scepticism towards China's increasing leadership on the world stage.

\section{Conclusion}

This chapter argues that China's influence in global health governance has been exaggerated. Given China's funding of the organization, its involvement in agenda setting, and its provision of expertise to the WHO, China's role in global health governance pales in comparison to its status as the world's second largest economy. China's domestic political institutional deficiencies have likewise limited China's capacity to offer timely medical responses, thus hindering the Chinese leadership in global health governance. It is evident that China has demonstrated some degree of leadership in fighting against the COVID-19 pandemic by pledging financial, medical, and professional assistance to virus-stricken countries. However, China's credibility in global health governance has suffered due to its missteps, including misinformation in the initial phase of the COVID-19 pandemic, and aggressive and incoherent narratives about the pandemic. Even if the US initial mismanagement of the pandemic serves to weaken its role as the leader of global health governance, neither China nor the rest of the world is ready for China to take over leadership in this area of global governance.

\section{References}

Archyde. 2020. 'Trump Ends the US Relationship with the WHO.' 30 May. Accessed 15 October 2020. https://www.archyde.com/trump-ends-the-us-relationshipwith-the-who/.

BBC News Chinese. 2020. 'Wuhan Feiyan: Wuhan Shizhang Anshi Yiqing Pilu Bujishi Zhongyang Youzeren.[Wuhan Pneumonia: Wuhan Mayor Implies that the Central Government Should be Responsible for Late Information Disclosure].' $B B C, 28$ January. Accessed 15 October 2020. https://www.bbc.com/zhongwen/ simp/chinese-news-51276069. 
Benney, Jonathan. 2016. 'Weiwen at the Grassroots: China's Stability Maintenance Apparatus As a Means of Conflict Resolution.' Journal of Contemporary China vol. 25, no. 99:389-405. https://doi.org/10.1080/10670564.2015.1104876.

Berger, Miriam, Abigail Hauslohner, Brittany Shammas, Samantha Pell, Michael Brice-Saddler, Colby Itkowitz, Katie Shepherd, Teo Armus, and John Wagner. 2020. 'Trump Terminates U.S. relationship with WHO, Claiming It Misled World About Coronavirus.' Washington Post, 30 May. Accessed ${ }_{15}$ October 2020. https:// www.washingtonpost.com/nation/2020/05/29/coronavirus-live-updates-us/.

Campbell, Kurt M. , and Rush Doshi. 2020. 'The Coronavirus Could Reshape Global Order: China Is Maneuvering for International Leadership as the United States Falters.' Foreign Affairs, 18 March. Accessed 10 October 2020. https://www.foreignaffairs.com/articles/china/2020-03-18/coronavirus-could-reshape-global-order.

CGTN. 2020. 'China to Donate \$20 Million to WHO for COVID-19 fight, Vow to Strengthen International Cooperation.' 9 March. Accessed 15 October 2020. https://news.cgtn.com/news/2020-03-08/WHO-says-COVID-19-cases-outsideChina-over-20-0oo-OGroKZiuME/index.html.

Dziedzic, Stephen. 2020. 'Coalition of 62 Countries Backs Joint Australian, EU Push for Independent Inquiry into Coronavirus Outbreak.' $A B C, 17$ May. Accessed 15 October 2020. https://www.abc.net.au/news/2020-05-17/ coronavirus-inquiry-world-health-assembly-china-covid-19/12256910.

Embassy of People's Republic of China in the United Kingdom. 2020. 'Ambassador Liu Xiaoming Gives Exclusive Interview on BBC's HARD talk.'Chinese-embassy. org, 30 April. Accessed 12 October 2020. http://www.chinese-embassy.org.uk/ eng/dshdjjh/t1775029.htm.

Erlanger, Steven. 2020. 'Global Backlash Builds Against China Over Coronavirus.' The New York Times, 19 August. Accessed 12 October 2020. https://www.nytimes. com/2020/05/03/world/europe/backlash-china-coronavirus.html.

Glassman , Amanda, and Brin Datema. 2020. 'What Is the World Health Organization Without the United States?' Center for Global Development, 26 May. Accessed 15 October 2020. https://www.cgdev.org/blog/ what-world-health-organization-without-united-states.

Gostin, Lawrence O. 2015. 'The Future of the World Health Organization: Lessons Learned From Ebola.' The Milbank Quarterly vol. 93, no. 3: 475-479. https://www. milbank.org/quarterly/articles/the-future-of-the-world-health-organizationlessons-learned-from-ebola/.

Hernández, Javier C. 2020. 'Trump Slammed the W.H.O. Over Coronavirus. He's Not Alone.' The New York Times, 29 May. Accessed 15 October 2020. https:// www.nytimes.com/2020/04/o8/world/asia/trump-who-coronavirus-china.html. Huang, Yanzhong. 2015. 'International Institutions and China's Health Policy.' Journal of Health Politics vol. 40, no. 1: 41-71. https://doi.org/10.1215/03616878-2854551. 
- 2017. 'China's Response to the 2014 Ebola Outbreak in West Africa.' Global Challenges vol. 1, no. 2:1-7. https://doi.org/10.1002/gch2.201600001.

Leng, Sidney. 2019. 'China's Fragmented Health Care System under Increasing Pressure as Nation Rapidly Ages.' South China Morning Post, 11 June. Accessed ${ }_{15}$ October 2020. https://www.scmp.com/economy/china-economy/article/3013976/ chinas-fragmented-health-care-system-under-increasing.

Li, Chen, Xiangdong Xu, Guanghua Zhou, Kai He, Tianliang Qi, Wei Zhang, Feng Tian, Qinghua Zheng, and Jianping Hu. 2019. 'Implementation of National Health Informatization in China: Survey.' JMIR Medical Informatics vol. 7, no. 1: 1-9. https://doi.org/10.2196/12238.

Ministry of Foreign Affairs. 2020. '2020 Nian Siyue 23Ri Waijiaobu Fayanren Geng Shuang Zhuchi Lixing Jizhehui [April 23 2020: Spokesman Geng Shuang from Ministry of Foreign Affairs hosted routine press meetings].'Ministry of Foreign Affairs of the People's Republic of China, 23 April. Accessed 15 October 2020. https://www.fmprc.gov.cn/web/fyrbt_673021/t1772736.shtml.

Pilling, David. 2020. 'WHO Chief Splits Opinion with Praise for China's Virus Fight.' Financial Times, 9 February. Accessed 15 Octorber 2020. https://www.ft.com/ content/57c6a1d6-49a7-11ea-aeb3-955839eo6441.

Ramesh, M, Xun Wu, and Alex Jingwei He. 2014. 'Health Governance and Healthcare Reforms in China.' Health Policy and Planning vol. 29, no. 6: 663-672. https:// doi.org/10.1093/heapol/czs1og.

Schaefer, Brett D. 2020. 'The World Health Organization Bows to China.' The Heritage Foundation, 28 April. Accessed 15 October 2020. https://www.heritage.org/ global-politics/commentary/the-world-health-organization-bows-china.

Taiwan Affairs Office and the Information Office of the State Council. 20oo. 'The One-China Principle and the Taiwan Issue.' People.cn, 1 February. Accessed 17 June 2021. http://en.people.cn/features/taiwanpaper/taiwan.html.

The Straits Times. 2020. 'Mask diplomacy: China Tries to Rewrite Coronavirus Narrative.' 2o March. Accessed 28 March 2021. https://www.straitstimes.com/ asia/east-asia/mask-diplomacy-china-tries-to-rewrite-coronavirus-narrative.

Tsirkin, Julie, Kasie Hunt, and Talbot Haley. 2020. 'Senate Republicans Investigating WHO and China's Coronavirus Response.' NBC, 15 April. Accessed 15 October 2020. https://www.nbcnews.com/politics/congress/ senate-republicans-investigating-who-china-s-coronavirus-response-n1183976.

Wong, Edward, Julian E. Barnes, and Zolan Kanno-Youngs. 2020. 'Local Officials in China Hid Coronavirus Dangers From Beijing, U.S. Agencies Find.' The New York Times, 19 August. Accessed 15 October 2020. https://www.nytimes. com/2020/08/19/world/asia/china-coronavirus-beijing-trump.html.

World Bank. 2018. 'China - Systematic Country Diagnostic: Towards a More Inclusive and Sustainable Development (English).' 14 Februrary. Accessed 17 June 2021. 
https://documents1.worldbank.org/curated/en/147231519162198351/pdf/ChinaSCD-publishing-version-final-for-submission-02142018.pdf.

World Health Organization (WHO). 2020. 'Pneumonia of Unknown Cause - China.' 5 January. Accessed 10 October 2020. https://www.who.int/csr/ don/o5-january-2020-pneumonia-of-unkown-cause-china/en/.

—. 2020a. 'World Health Assembly.' Accessed ${ }_{15}$ September 2020. https://www. who.int/about/governance/world-health-assembly.

—. 2020b. 'Contributors.' Accessed 28 March 2020. https://open.who.int/2020-21/ contributors/contributor.

—. 2020c. 'WHO Collaborating Centres: Global Database.' Accessed 19 September 2020. https://apps.who.int/whocc/ReportDetails.aspx?mAEVTJR3NR508XZFqVkkZA==.

Xi, Jinping. 2020. 'Speech by President Xi Jinping at Opening of 73rd World Health Assembly.' Xinhua, 18 May. Accessed 12 October 2020. http://www.xinhuanet. com/english/2020-05/18/c_139067018.htm.

Xinhuanet. 2019. '70 Nianlai Woguo Renjun Yuqi Shouming Cong 35 Sui Tigaodao 77 Sui [For the past 70 years, our national life expectancy increased from 35 to 77].' 22 August. Accessed 15 October 2020. http://www.xinhuanet.com/ politics/2019-08/22/c_1124909249.htm.

Yip, Winnie, and William C. Hsian. 2008. 'The Chinese Health System At A Crossroads.' Health Affairs vol. 27, no. 2: 46o-468. https://doi.org/10.1377/ hlthaff.27.2.46o.

Yip, Winnie, Hongqiao Fu, Angela T. Chen, Tiemin Zhai, Weiyan Jian, Roman Xu, Jay Pan. 2019. '10 years of health-care reform in China: progress and gaps in Universal Health Coverage.' The Lancet vol. 394, no. 10204: 1192-1204. https:// doi.org/10.1016/So140-6736(19)32136-1.

Zhang, Lu. 2020. . 'Zhong Nanshan: CDC diwei yinggai tigao, yaoyou xingzhengquan [Zhong Nanshan: CDC Should Be Empowered with Administrative Authority].' Bjnews, 27 February. Accessed 15 October 2020. http://www.bjnews.com.cn/ feature/2020/02/27/695815.html.

Zhao, Suisheng. 2020. 'Rhetoric and Reality of China's Global Leadership in the Context of COVID-19: Implications for the US-led World Order and Liberal Globalization.' Journal of Contemporary China vol. 30, no. 128: 233-248. https:// doi.org/10.1080/10670564.2020.1790900.

\section{About the Authors}

Xue GONG is Assistant Professor at the S. Rajaratnam School of International Studies, Nanyang Technological University, Singapore. Her research interests include international political economy, Asian regionalism and 
global governance. She has contributed to peer-reviewed journals such as World Development, International Affairs, the Pacific Review, Contemporary Southeast Asia, and Harvard Asia Quarterly. She co-edited Securing the Belt and Road Initiative: Risk Assessment, Private Security and Special Insurances Along the New Wave of Chinese Outbound Investment (Palgrave Macmillan 2018), and has contributed to several book chapters on China's economic statecraft in Southeast Asia. She has also contributed various Op-Ed articles.

Xirui LI is a PhD student at the S. Rajaratnam School of International Studies, Nanyang Technological University. Her research interests include Global Economic Governance, Regional Integration and Central-Local Relations in China's International Political Economy. She is the translator of Power and its Logics (Chinese version, Social Science Academic Press (China), 2020) and has contributed several commentaries in The Diplomat. 


\title{
5 South Korea and the WHO during the COVID-19 Crisis ${ }^{1}$
}

\author{
Brendan HOWE
}

\begin{abstract}
The World Health Organization (WHO) has faced uncooperative great powers in managing global health crises. The contemporary operating environment has given middle powers the opportunity to shine. South Korea, in particular, has seized the chance to gain more bang for its diplomatic buck by demonstrating its good global citizenship. This chapter evaluates how the Republic of Korea (ROK) has not only followed and promoted WHO guidelines, but also has been at the forefront of developing measures to combat the coronavirus. In doing so, it has gained significant political capital. The ROK is likely to continue and even increase its support of WHO governance precisely because it is in the country's national interest to do so.
\end{abstract}

Keywords: international organizations, South Korea (Republic of Korea), World Health Organization, multilateral institutions, international health management, national interest

\section{Introduction}

Global pandemics throw into stark relief the dualistic paradox of international organization and global governance through international organizations (IOs). International organization is a transitional process, from the international anarchic conditions that generate conflict towards

1 The author is deeply grateful for the assistance of Sukyung Kim, graduate student at Ewha Womans University Graduate School of International Studies, in carrying out research for this chapter.

Van der Veere, Anoma P., Florian Schneider, and Catherine Yuk-ping Lo (eds), Public Health in Asia during the COVID-19 Pandemic: Global Health Governance, Migrant Labour, and International Health Crises. Amsterdam, Amsterdam University Press 2022 DOI: 10.5117/9789463720977_CHO5 
the aspiration of global governance. Through this process states are actively brought together to solve common problems, reconcile conflicting interests, and generate collective good, including a more peaceful and secure operating environment. International organizations (IOs) represent the phase of that process which has been reached at a given time (Claud 1963, 4). These institutions form a key plank of the liberal international order, but remain controversial, and are increasingly coming under attack. On the one hand IOs are creations of the states that make up their membership and which they serve so as to make the sovereign interstate system function better. On the other hand, as I have explored elsewhere, IOs require a degree of alienation or transference of state sovereignty (Howe 2020b, 18).

The liberal international order of international cooperation through multilateral institutions such as the United Nations (UN), the World Trade Organization (WTO), and the World Health Organization (WHO), championing the policy platforms of open markets, collective security, and the promotion of liberal democracy, is further challenged by the abdication of leadership by the United States (US) and increasing contestation between the US and China and Russia. In addition, as I have also examined in a related publication, non-traditional security (NTS) issues such as COVID-19 and other pandemics, pose major challenges for the traditional state-centric models upon which much strategic decision-making is based (Howe 2020a). Nowhere is this truer than in the state-centric East Asian operating environment.

The responses of the three great powers (the US, China, and Russia) to the COVID-19 crisis, as well as those of some second-tier powers such as the United Kingdom (UK), Brazil, and India, have left much to be desired in terms of both international and domestic leadership. Japan's response has also received at best mixed reviews. These countries have not only demonstrated a lack of leadership, but also their responses have been relatively unsuccessful. Indeed, they have, on the whole, contributed to the challenges faced by the WHO, rather than supporting the organization in carrying out its global governance and systemic health security mission (Howe 2020a). In contrast, middle powers, particularly those in the Asia-Pacific region such as the Republic of Korea (ROK), ${ }^{2}$ Taiwan, Vietnam, and New Zealand, have received glowing evaluations of their responses and their support for multilateral health governance efforts. Salmon (2020) has noted that perhaps the most startling trend seen during the global COVID-19 pandemic has been 
the vast difference between East Asia and the West. East Asia has handled and contained the pandemic far better than the West on nearly all metrics.

This chapter first assesses the shortcomings of great power leadership in international health management and the great powers' lack of support for the WHO's global governance mission. It then turns to analyse South Korea's response to the pandemic, contrasting the country's close adherence to WHO guidelines and support of international health management with the failings of the great powers. Finally, the chapter argues that we can be optimistic about continued ROK leadership in these fields. The ROK is likely to continue showing leadership not only because of a moral commitment to normative foreign policy, but also because it is in its national interest to act in this way.

\section{Divergent Responses}

Chinese and US responses to global health crises and pandemics can be viewed as two ends of a continuum between authoritarian and libertarian influenced governance (Howe 2017). In China a lack of transparency, and a lack of freedom of information and speech, has allowed pandemics to spread and endanger vulnerable individuals and groups in the country, the region, and across the globe. When the Chinese government has acted, it has tended to act unilaterally and in an authoritarian rather than open manner, imposing comprehensive lockdowns that exacerbated socio-economic vulnerabilities. In contrast, during the current COVID-19 pandemic, the US government agencies were slow to respond to the pandemic, due to concerns about economic impacts of restrictions, but also out of concern for the impact restrictions would have upon civil liberties and individual freedoms. These concerns have also created pressures for a premature lifting of restrictions (Howe 2020b, 18). As a result, the US is now the most severely impacted country in the world (Worldometers 2020).

Internationally, China and the US have focused on blaming each other for the impact of COVID-19. They have resorted to national interest security promotion rather than collective action and have shown inconsistent support for the WHO's mission and even outright hostility towards it.

The ways that great power obstruction could hinder the WHO in carrying out its global health governance were also evident during the 2002-2004 SARS coronavirus (SARS-CoV) outbreak. SARS-CoV first infected humans in the Guangdong province of southern China in 2002. It rapidly turned into a pandemic that affected 26 countries and resulted in more than 8000 cases 
in 2003, before dying out with only a small number of cases in 2004 (WHO 2020a). The Chinese authorities were initially unwilling to cooperate with the WHO due to considerations of national interest and state sovereignty (Wong and Zheng 2004). Lack of epidemiological information about the disease hampered the prompt application of effective control measures, something that was also the case with the Hong Kong authorities where the disease soon spread. Because of inadequate communication, 'panic developed in the community and weakened cooperation and support from the public' (Hung 2003, 376).

During the current COVID-19 crisis, the WHO has once again faced an uncooperative great power. This time, however, it has been the US hegemon working against the global governance mission. On 29 May 2020, President Donald Trump said he would make good on his threat to withdraw from the WHO. This has been described as 'an unprecedented move that could undermine the global coronavirus response and make it more difficult to stamp out other disease threats' (Ehley \& Ollstein 2020). The US gave US $\$ 893$ million to the WHO between 2018-2019, of which US\$237 million were assessed contributions (the dues countries pay in order to be a member of the Organization). It still owes approximately US $\$ 392$ million through various multiyear cooperative agreements (Liberman 2020). As by far the largest state donor to the organization, the US's conflict with the WHO could have a devastating impact on the latter's global health governance mission. In one of his first acts as President, Joe Biden did walk back the former administration's plan to withdraw the US from the WHO, but there remain concerns about 'perfidious America' in this, as well as other areas of global governance.

Despite these concerns, even at existing levels of support, there is hope for the WHO governance mission in the form of support from middle powers and non-state actors. While the US may be the largest donor, the top ten donors list is rounded out by three middle powers, namely the UK, Germany, and Japan. Also in the top ten are four civil society organizations, the Bill \& Melinda Gates Foundation, the GAVI Alliance, Rotary International, and the National Philanthropic Trust. Then there are two IOs, the United Nations (UN) Office for the Coordination of Humanitarian Affairs (UNOCHA) and the European Commission (WHO 202ob).

The dominance of small and medium-ranked powers, as well as civil society organizations, is even more pronounced when it comes to Core Voluntary Contributions (CVCs). CVCs are fully unconditional (flexible), meaning the WHO has full discretion on how these funds should be used to fund its programmatic work. The main providers of CVCs, in order of 
support, are the UK, Sweden, Norway, Australia, the Netherlands, Belgium, Denmark, Switzerland, Luxembourg, France, the Estate of Mrs. Edith Christina Ferguson, Spain, the Estate of the Late Marjory Miller Thompson, Monaco, and Miscellaneous (ibid.).

The extensive support given to the WHO by middle powers means it is important to examine how states such as the ROK relate to the organization. In the following sections, this chapter first looks at how the ROK is acting in accordance with the global health governance mission of the WHO. It then discusses what potential South Korea may hold for future leadership in the field.

\section{The ROK, the WHO, and Respiratory Pandemics}

South Korea joined the WHO in 1949. It was covered by the WHO Representative Office in Taipei, Republic of China (Taiwan) between 1959 and 1965, when the WHO Representative Office in the ROK was established. The WHO Country Liaison Office had been established in 1962, and this then became a Representative Office in 1965 before changing back to a Country Liaison Office in 1999 (WHO 2020c). During the 2003 SARs-CoV outbreak, the ROK government worked closely with the WHO, taking rapid action to prevent further spread of the virus (The Briefing 2020). As a result, only three confirmed cases were reported in South Korea, and no deaths. This was despite the country being close to the epicentre of the virus in China and also having many ties to it. The low numbers in the ROK compare with a global total of 8437 probable cases and 813 deaths cases (WHO 2003).

South Korea did not, however, escape so lightly when the region was struck by a second respiratory pandemic. In 2015, MERs-CoV inflicted 186 laboratory-confirmed cases and 38 deaths (WHO 2015). Unlike during the SARS-CoV epidemic, the ROK government's response to MERs-CoV was widely criticized by the Korean public, particularly its initial reaction (Yonhap 2015). Yet the ROK learned important lessons (both positive and negative) from dealing with these two epidemics. These lessons were to stand them in good stead with the outbreak of COVID-19, which was first reported in Wuhan, China, at the end of December 2019 (Kim 2020).

The South Korean Ministry of Health and Welfare (MOHW) reported this new disease to its population on 3 January 2020. It announced strengthened surveillance for pneumonia cases in health facilities. On 20 January 2020, the first case of infection in South Korea was reported. The government accordingly scaled up its national alert level from blue to yellow and established 
more intense guidelines (MOHW 2020). ${ }^{3}$ More proactive measures against the virus were implemented from the end of January. These were put in place after the meeting of the Emergency Committee of the WHO where the Director General declared a 'Public Health Emergency of International Concern (PHEIC)'. The Korea Centers for Disease Control and Prevention (KCDC) started to closely monitor the changes in the international situation to prepare its response system. They also held a risk assessment meeting. In September 2020, the KCDC had its status upgraded to become an independent government agency, the Korea Disease Control and Prevention Agency, or KDCA, in recognition of its performance (KBS 2020).

As the situation worsened, and other countries gradually closed their borders to people from China, there were great pressures for the ROK to do the same. Despite this, the Korean government announced that South Korea would not entirely restrict entry from China unless explicitly advised to do so by the WHO (Kim and Kim 2020). As the situation continued to deteriorate, public dissatisfaction towards president Moon Jae-in and the WHO's conservative approach grew (Kang 2020). An unpredictable and blurred situation led to increasing demand for Personal Protective Equipment (PPE), especially masks, which then surged in price (SBS 2020).

Government guidelines for wearing masks were initially ambiguous, leaving the public confused. In the middle of February, therefore, the Korean Medical Association (KMA) and the Ministry of Food and Drug Safety jointly provided advice regarding the use of masks, referring to the WHO guidelines published in late January (Yonhap News 2020a). In contravention of the WHO mask guidelines, the government still controversially allowed its population to reuse disposable masks if these were not too contaminated. They did this out of concern that panic buying could lead to potential mask shortages for the medical field and vulnerable individuals and groups (Jeon 2020). A few days later, however, the government published new guidelines citing the WHO advice that keeping social distance was more important than wearing a mask (Yonhap News 202ob).

Furthermore, when masks did run low, and there was a temptation to hoard or increase prices, the government stepped in and rationed the number of price-controlled masks that could be bought by an individual. Depending on date of birth, each citizen was allotted a day on which they could buy masks. Early in the pandemic, free hand sanitizer was to be found next to and in the elevators of every building. With a slight resurgence of infections

3 South Korea operates a four-colour warning system: 1: Blue - Exercise normal precautions; 2: Yellow - Exercise increased caution; 3: Orange - Reconsider travel; 4: Blue - Do not travel 
in May 2020, tens of thousands of people were tested within days. People who were potentially infected were contacted to six degrees of separation. The government cooperated with phone companies and bank card issuers to carry out this contact tracing. In May, the wearing of masks on all forms of public transport also became mandatory (Howe 2020a).

South Korea's response to the crisis, while initially a little slow, has seen a combination of governmental policy and domestic constituency societal engagement that has won praise from around the world. Of course, there have been many infected, and the economy has been dealt a serious blow. Yet the WHO guidelines have found a champion in the ROK. The main ways South Korea has been able dramatically to reduce infections while not resorting to economically devastating lockdown are through a combination of aggressive testing and contact tracing and universal mask use. On the government side, due to the previous pandemic scares, preparations were already in place to ramp up dramatically the production of tests, masks, and PPE. Likewise, work had already been done on contact tracing technology in South Korea, which has one of the most connected societies in the world. On the society side, people are already well-used to wearing masks due to the pollution, and out of consideration for others when suffering from a cold, and are willing to accept a degree of invasiveness in their lives due to national security considerations (Howe 2020a).

South Korea has also taken on part of the international burden of tackling COVID-19, as well as other infectious diseases. After being designated in 2019, South Korea has become a member of the WHO's executive board for the period 2020 through to 2023. This will allow it to play an important role in screening the WHO's budget and in policy implementation and strategy development. The 'Korea-WHO Country Strategy 2019-2023' outlines the regional and global leadership role that the ROK will perform and invites South Korea to open global forums and lead regional commitment for strengthening health regulatory systems (WHO 2019).

\section{Middle Powers, Niche Diplomacy, and Global Health Governance}

South Korea has therefore stepped forward to stand at the vanguard of the quarantine management system. As one of the most successful infection control cases, with its transparency and innovative testing strategy, South Korea's effort to combat COVID-19 has earned the praise of the WHO. In addition, the WHO has revealed its intention to participate in the domestic cohort research conducted by Korean medical teams (Herald Economy 2020). The WHO has also asked South Korea to supply test kits to the African region, which have 
been requested by over 120 countries (Shin and Park 2020). In addition, through web-conferencing, the ROK government has been sharing their know-how and promoting the Korean quarantine system as a way of responding to COVID-19.

The South Korean knowledge sharing activity includes regular web seminars about 'K-Defence Prevention' with health care officials around the world. It also includes the holding of tripartite health minister conferences between ministers from Korea, China, and Japan. At these conferences, the ROK has stressed the need for international solidarity against the virus and discussed support for the WHO and the WHO Western Pacific Regional Office. At the $73^{\text {rd }}$ World Health Assembly (WHA), which addressed responses to the COVID-19 pandemic, President Moon announced in his keynote speech that the government planned to provide US\$10o million worth of additional humanitarian assistance (Korea Herald 2020). This is a very significant increase given that South Korea's assessed contribution to the WHO in 2020-2021 had been US\$54 million dollars (WHO 2020d).

Beyond simply promoting the K-defence system, South Korea has been at the forefront of seeking international cooperation. A ROK-led multilateral cooperation group, the Support Group for Infectious Disease Response (G4IDR), based in Geneva, brings together a number of countries along with the eight core members (Singapore, Turkey, United Arab Emirates, Morocco, Kenya, Mexico, and Peru) to collaborate with the WHO and other global health organizations like Unitaid (MOFA 2020). In addition, the Korean Ministry of Foreign Affairs (MOFA) has hosted a conference, headed 'COVID-19 situation by region and response status of overseas diplomatic missions, future Corona 19 response and policy direction', to establish and promote the development cooperation initiative (Ministry of Interior and Safety 2020). As part of these efforts, a total of 36 billion won (US\$31 million) worth of aid has been announced, under the name of 'Comprehensive Emergency Support Program for Corona 19 Response'. This aid will be given to India (New Southern), Ethiopia (Africa), Uzbekistan (New Northern), Colombia (Latin and South America), and five ASEAN target countries.

South Korea has been criticized in the past for only pursuing normative foreign policies when doing so garners some benefit to the country (Kalinowski and Cho 2012, 249). Unlike some other donors, however, these national interest considerations mean that the ROK is likely to follow through on all its pledges and abide by all its humanitarian commitments. The government headed by President Moon Jae-in has been in power throughout the period when COVID-19, this greatest of humanitarian challenges, has impacted upon domestic and international governance. The normative foreign policy activism of the Moon administration fits well with the ROK tradition of middle power niche diplomacy. 
Middle powers like South Korea lack 'compulsory power', in that they do not have the military resources to dominate other countries or the economic resources to bribe them. They differ, however, from the small or 'system ineffectual' states which have little or no influence because they are, potentially, 'system affecting states' that can have significant impact within a narrower policy area or in conjunction with others (Vom Hau, Scott, and Hulme 2012, 187-8). To maximize their relevance and impact, a degree of selectivity on the part of these middle powers is required. This means the pursuit of 'niche diplomacy,' which involves concentrating resources in specific areas best able to generate returns worth having, rather than trying to cover the field, allowing them to 'punch above their weight' (Henrikson 2005, 67).

In search of a diplomatic 'niche', successive recent administrations in Seoul have stressed a commitment to variations of 'principled foreign policy'. The Moon administration has not directly identified its diplomatic character as that of a middle power. Yet there is evidence of such thinking in its 'onehundred major policy tasks' which includes a section describing foreign policy goals. In these, the overarching themes of the administration include 'responsibility', 'multilateralism', and 'values'. In this context, 'responsibility' means that South Korea will fulfil its regional and global governance duties. This, it can be argued, is one of the characteristics of a middle power in the international community. Given this, it can be expected that contemporary South Korean foreign policy will focus on multilateralism with an emphasis on universal values, such as human rights, democracy, and rule of law.

\section{Conclusion}

Although the Moon Administration has not explicitly branded itself as a middle power, its de facto foreign policy strategy remains deeply wedded to middlepower diplomacy. Indeed, these elements of the Moon Administration's foreign policy platform represent a continuation of regional and global humanitarian multilateralism. President Moon's aspirational project for a 'Northeast Asia Plus Community' (NEAPC) of responsibility aims to build a sustainable system of regional cooperation. ${ }^{4}$ This project has an ambition to ultimately produce a people-centred peace community that advocates co-prosperity.

4 This community is envisaged as bringing together states and frameworks within and beyond the region including the US, China, Japan, Russia, Mongolia, Australia, New Zealand, ASEAN (and its member states), the Trilateral Cooperation Secretariat (TCS), the UN, NATO, EU, and OSCE. 
President Moon (2020) has sought to use the current crisis as a driving force for new opportunities and development. He aspires to realise 'a Republic of Korea that takes the lead in the world'. These statements, delivered to mark the third anniversary of his inauguration, represent a continuation of Korea's humanitarian middle power niche diplomacy, but also an attempt to drive it forward by taking advantage of the post-COVID operating environment (Howe 2020b). As such, therefore, the government of the ROK is likely to continue and even increase its support of WHO governance precisely because it is in the country's national interest to do so.

\section{References}

Claude, Innis. 1963. Swords into Plowshares: The Problems and Progress of International Organization. New York: Random House.

Ehley, Brianna, and Alice Miranda Ollstein. 2020. 'Trump Announces U.S. Withdrawal from the World Health Organization.' Politico, 29 May. Accessed 1 January 2021. https://www.politico.com/news/2020/05/29/ us-withdrawing-from-who-289799.

Henrikson, Alan. 2005. 'Niche Diplomacy in the World Public Arena: The Global 'Corners' of Canada and Norway' in Jan Melissen (ed.) The New Public Diplomacy: Soft Power in International Relations. Basingstoke: Palgrave Macmillan.

Herald Economy. 2020. 'WHO Shows its Intention to Join 'South Korea's Successful COVID-19 Response.' 19 March. Accessed 1 January 2021. http://news.heraldcorp. com/view.php?ud=20200319000189.

Howe, Brendan. 2017. 'Civic Virtue: The Rights and Duties of Citizenship.' Philosophia vol. 18 , no. 1: 102-117.

-. 2020a. 'Rising to the Challenge of COVID-19: The Role of South Korea and New Actors.' Open Asia. https://www.openasia.asia/ covid-19-south-korea-and-new-actors-brendan-howe/.

—. 2020b. 'Comprehensive Security and Sustainable Peacebuilding in East Asia.' Korean Journal of Security Affairs vol. 25, no. 1: 5-33.

Hung, Lee Shiu. 2003. 'The SARS Epidemic in Hong Kong: What Lessons Have We learned?' Journal of the Royal Society of Medicine vol. 96, no. 8: 374-378.

Jeon, Yejin. 2020. 'Because of Scarcity in Supplying Masks... Government Announced that Reusing Masks and Cotton Masks Are Also Safe.' HanKyung, 3 March. Accessed 1 January 2021. https://www.hankyung.com/society/article/2020030333111.

Kalinowski, Thomas and Hyekyung Cho. 2012. 'Korea's Search for a Global Role between Hard Economic Interests and Soft Power.' European Journal of Development Research vol. 24: 242-26o. 
Kang, Tae-jun. 2020. 'Public Anger Swells in South Korea over Corona Virus Outbreak.' The Diplomat, 28 February. Accessed 1 January 2021. https://thediplomat. com/2020/o2/public-anger-swells-in-south-korea-over-coronavirus-outbreak/.

Kim, Hyung Jung. 2020. 'South Korea Learned its Successful Covid-19 Strategy from a Previous Coronavirus Outbreak: MERS.' The Bulletin, 20 March. Accessed 1 January 2021. https://thebulletin.org/2020/o3/south-korea-learnedits-successful-covid-19-strategy-from-a-previous-coronavirus-outbreak-mers/.

Kim, Pyung-hwa, and Seong-hwi Kim. 2020. 'Government 'Restriction on Chinese Entrant Has Not Been Discussed, No Decision Without WHO's Advice'.' Money Today, 27 January. Accessed 1 January 2021. https://news.mt.co.kr/mtview. php?no=2020012716147694900.

Ko, Il-seok. 2020. 'SARS, MERS, and COVID-19... Differences in Response Systems.' The Briefing, 27 January. Accessed 1 January 2021. http://thebriefing.co.kr/news/ articleView.html?idxno $=382$.

Korea Broadcasting System (KBS). 2020. 'Independent KDCA Takes the Lead in Infectious Disease Control.' 12 September. Accessed 1 January 2021. https://world. kbs.co.kr/service/news_view.htm?lang=e\&Seq_Code=156225.

Korea Herald. 2020. 'Full text of President Moon's special address for the World Health Assembly Session.' 18 May. Accessed 1 January 2021. http://www.koreaherald.com/view.php?ud=20200518000922.

Lieberman, Amy. 2020. 'US Says It Will Cut WHO Funding. What Happens Next?' Devex, 11 June. Accessed 1 January 2021. https://www.devex.com/news/ us-says-it-will-cut-who-funding-what-happens-next-97439.

Ministry of Foreign Affairs (MOFA). 2020. ROK Leads Launch of Support Group for Global Infectious Disease Response (G4IDR). 21 May. Accessed 1 January 2021. http://www.mofa.go.kr/eng/brd/m_5676/view.do?seq=321097.

Ministry of Health and Welfare (MOHW). 2020. 'Press Release on the First Imported Case of the Novel Coronavirus (2019-nCoV) in Korea.' 20 January. Accessed 1 January 2021. http://www.mohw.go.kr/eng/nw/nwo1o1vw. jsp?PAR_MENU_ID $=1007 \& M E N U \_I D=100701 \&$ page $=4 \& C O N T \_S E Q=352468$.

Ministry of Interior and Safety. 2020. 'Korea's Response to COVID-19 and Future Direction.' 7 May. Accessed 1 January 2021. http://www.mofa.go.kr/ eng/brd/m_22591/view.do?seq=11\&srchFr=\&amp;srchTo=\&amp;srchWor $\mathrm{d}=\&$ amp;srchTp=\&amp;multi_itm_seq=o\&amp;itm_seq_1=o\&amp;itm seq_2=o\&amp;company_cd=\&amp;company_nm=\&page $=1 \&$ titleNm $=$.

Moon, Jae-in. 2020. 'President Moon's Special Address.' Korea Times, 11 May. Accessed 1 January 2021. https://www.koreatimes.co.kr/www/nation/2020/05/356_289260. html.

Salmon, Andrew. 2020. 'Why East beat West on Covid-19.' Asia Times, 15 May. Accessed 1 January 2021. https://asiatimes.com/2020/05/why-east-beat-west-on-covid19/. 
Seoul Broadcasting System (SBS). 2020. 'Shortage of Masks Even in the Hospital... Restriction on Overseas Export.' 5 February. Accessed 1 January 2021. https://news.sbs.co.kr/news/subusuNews.do?plink=GNB\&cooper=SBSNEWS.

Shin, Nari, and Hyo-mok Park. 2020. 'WHO Asked South Korea to Support Test-Kits in Africa Regions.' DongA, 7 April. Accessed 1 January 2021. http://www.donga. com/news/article/all/20200407/100530210/1.

Vom Hau, Matthias, James Scott, and David Hulme. 2012. 'Beyond the BRICs: Alternative Strategies of Influence in the Global Politics of Development.' European Journal of Development Research vol. 24, no. 2: 187-204.

Wong, John and Yongnian Zheng. 2004. The SARS Epidemic: Challenges to China's Crisis Management. Singapore: World Scientific.

World Health Organization. 2003. 'Cumulative Number of Reported Probable Cases of SARS.' 7 November. Accessed 1 January 2021. https://www.who.int/csr/sars/ country/2003_07_11/en/.

—. 2015. 'MERS outbreak in the Republic of Korea.' 28 July. Accessed 1 January 2021. https://www.who.int/westernpacific/emergencies/2015-mers-outbreak.

- 2019. 'WHO Country Cooperation Strategy 2019-2023: Republic of Korea.' Accessed 1 January 2021. http://iris.wpro.who.int/handle/10665.1/14327.

- 2020a. SARS (Severe Acute Respiratory Syndrome). Accessed 1 January 2021. https://www.who.int/ith/diseases/sars/en/.

—. 2020b. 'How WHO is funded.' Accessed 1 January 2021. https://www.who.int/ about/planning-finance-andaccountability/how-who-is-funded.

-. 2020c. 'WHO History.' https://www.who.int/republicofkorea/about-us.

- 2020d. Notice of Assessment by Member State for the Biennium 20202021. 30 September. Accessed 1 January 2021. https://www.who.int/about/ finances-accountability/funding/assessed-contributions/en/.

Worldometers. 2020. 'Coronavirus.' 13 June. Accessed 1 January 2021. https://www. worldometers.info/coronavirus/.

Yonhap News. 2015. 'MERS Quarantine Authority Becomes a Liar... Distrust by the Public.' 2 June. Accessed 1 January 2021. https://www.yna.co.kr/view/AKR2015 o602053400017?input=1195m.

- 2020a. 'No necessity to wear a mask with short outdoor activity.' 12 February. Accessed 1 January 2021. https://www.yna.co.kr/view/AKR20200212137500017 ?input=1195m.

- 2020b. 'Government Advice on the Reuse of Masks: 'Less Contaminated Masks Can Be Used again'.' 26 February. Accessed 1 January 2021. https://www.yna. co.kr/view/AKR20200226093951017?input=1195m. 


\section{About the Author}

Brendan HOWE is Dean and Professor of International Relations at Ewha Womans University Graduate School of International Studies, and President of the Asian Political and International Studies Association. His research focuses on traditional and non-traditional security in East Asia, human security, comprehensive peacebuilding, middle powers, post-crisis development, and conflict transformation. He has authored, co-authored, or edited more than 90 related publications including The Niche Diplomacy of Asian Middle Powers (Lexington Books, 2021), UN Governance: Peace and Human Security in Cambodia and Timor-Leste (Springer, 2020), Regional Cooperation for Peace and Development (Routledge, 2018), Peacekeeping and the Asia-Pacific (Brill, 2016), Post-Conflict Development in East Asia (Ashgate, 2014), and The Protection and Promotion of Human Security in East Asia (Palgrave, 2013). 



\title{
6 Escaping the 'Realist Trap'
}

\author{
The ROC's Participation in Global Health Governance Under \\ the One-China Principle
}

Catherine Yuk-ping LO

\begin{abstract}
Drawing on the perspectives about global governance offered by realist international relations theory, this chapter aims to demonstrate that international institutions of global health governance are just another arena of world politics that is vulnerable to manipulation by powerful states. The utility of realism in understanding global health governance is examined by looking at the case of Taiwan, also named the Republic of China (ROC), and the COVID-19 pandemic. The case study shows how the One-China Principle has restricted interactions between the World Health Organization (WHO) and the ROC during health emergencies. While the constraints seem formidable, this paper argues that the ROC can potentially escape the 'realist trap' because of its de facto status, participating in global health governance in a meaningful way
\end{abstract}

Keywords: Taiwan (Republic of China), One-China Principle, global health governance, realism, World Health Organization (WHO), COVID-19

\section{Introduction}

There has been an ongoing debate in the field of international relations about the role of international institutions (Schweller and Priess 1997, 2). Institutionalists claim that international institutions can move states towards cooperation to promote the general welfare of states (Schweller and Priess 1997, 8). In contrast, realists perceive institutions as arenas for great powers to secure and advance their national interests (Mearsheimer

\footnotetext{
Van der Veere, Anoma P., Florian Schneider, and Catherine Yuk-ping Lo (eds), Public Health in Asia during the COVID-19 Pandemic: Global Health Governance, Migrant Labour, and International Health Crises. Amsterdam, Amsterdam University Press 2022 DOI: 10.5117/9789463720977_CHo6
} 
1994/1995, 7). In light of this debate, this chapter considers the influence that the People's Republic of China (PRC) has had on the engagement of the Republic of China (ROC) in the World Health Organization (WHO) during the COVID-19 pandemic. The chapter shows that this demonstrates the realist prediction of the vulnerability of international institutions to great power politics.

With the increasing pressure exerted on the ROC by the PRC, and the ambiguous international status of the former, scholars have argued that the ROC's participation in global health governance is minimal and insignificant (Chen 2018, 264). However, this chapter posits that the de facto status of the ROC to a certain extent helps it escape the so-called 'realist trap' that state actors often encounter in global health governance. ${ }^{1}$ This realist trap refers to the way in which states that seek to engage in international cooperation face problems, including other states freeriding in the cooperation, or other states failing to comply with norms and regulations (Mearsheimer 1994/1995, 12). By escaping realist entrapment, the ROC can potentially participate in global health governance in a meaningful way. This chapter proceeds as follows: It begins with an overview of the ROC's participation in the WHO. Applying a realist perspective, the chapter evaluates how, before and during the COVID-19 pandemic, the PRC has sought to secure its national interest regarding the ROC in the international community. The chapter concludes with a discussion of the future participation of the ROC in global health governance.

\section{The ROC in Global Health Governance and the One-China Principle}

The Republic of China (Taiwan) used to be a key player in global health governance, and was one of the founding members of the WHO in 1948. After the communists won control of mainland China, during the Chinese Civil War that lasted until 1949, the Chinese nationalists (Kuomintang) retreated to Taiwan. Since then, both the PRC and ROC have claimed sole representation of the Chinese nation. However, after the end of the civil war, the ROC remained a member of the WHO and other United Nations organizations. Following the US rapprochement with China in the early

1 The term 'realist trap' comes from an article written by Davenport $(2011,40)$ which argues for the entrapment of Marxism in realist thoughts: Davenport, Andrew. 2011. 'Marxism in IR: Condemned to a Realist fate?' European Journal of International Relations vol. 19: 27-48. 
1970s, in 1971 the PRC replaced the ROC as the sole Chinese representative at the UN (Winkler 2012). The ROC's loss of its UN membership triggered a domino effect, with many other states then 'de-recognizing' the ROC's statehood. Between 1971 and 1979, at least 46 governments broke relations with the ROC (Hickey 2007, 9).

Meanwhile, the PRC began campaigns against the ROC's membership in international institutions under the One-China Principle. The One-China Principle is the name referred to by the PRC, while the same arrangement is referred to as 'the 1992 Consensus' by the ROC. Under the One-China Principle/the 1992 Consensus, both the PRC and ROC acknowledge that there is 'one China' but each side has its own interpretation of what 'China' means. From the PRC's perspective, Beijing is the sole legitimate government representing the whole of China, and Taiwan is not a sovereign state but rather a 'breakaway' province. Based on this perspective, the ROC should be replaced and represented by the PRC in all international organizations

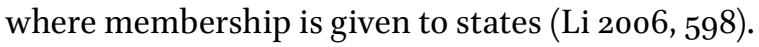

Because of the PRC campaigns carried out in the 197os, the ROC lost representation in numerous international organizations, including the WHO (Li 2006, 598). Being excluded from the international health regime, the ROC government no longer had access to timely and first-hand information regarding global infectious disease outbreaks. It could not participate in WHO meetings discussing disease mitigation strategies or receive direct assistance in disease control and surveillance. However, the 2003 Severe Acute Respiratory Syndrome (SARS) crisis led to greater international concern over the absence of the ROC from global responses to disease outbreaks. The crisis served as a wake-up call, pointing to the need for the WHO and other states to reconsider the ROC's role in global health governance. As a result, the ROC itself, as well as several member states started calling for its inclusion as an observer in the World Health Assembly (WHA), the WHO's decision-making body (Hickey 2007, 105), for statehood is not a requirement at the WHA.

The ROC's engagement in global health governance was boosted when it was granted observer status in the WHA in 2009. The WHO's decision was based on an ad hoc arrangement as part of the One-China Principle. This arrangement stated that the ROC's participation in international organizations would be 'based on the agreement reached through consultations between the Chinese government and the international organizations [i.e., the WHO in this case] concerned' (Li 2006, 602). This pre-screening mechanism was established to provide the PRC with some flexibility to manage the issue, while preventing the ROC from 
utilizing increased global participation to push for de jure independence (Glaser 2013).

However, despite gaining the possibility to participate in the WHO, Taiwan's ability to engage in the WHO's work and technical activities remained limited. One important reason for this was that, in 2005, the PRC government signed a secret Memorandum of Understanding (MOU) with the WHO secretariat. This memorandum acknowledged the PRC government's power over the ROC's participation in the WHO/WHA (Glaser 2013). This meant that ROC experts who planned to attend WHO meetings were required to apply five weeks in advance, submitting participant lists to the PRC government for approval. If ROC experts were invited to a conference, then the WHO was also required to invite experts from the PRC. In addition, higher-level ROC officials were restricted from attending any WHO activities. All communications between the ROC and the WHO were to be made through the PRC.

In the ROC elections of 2016, the Democratic Progressive Party (DPP) candidate Tsai Ing-wen, who is very sceptical of the PRC, was elected as president. Following this, the One-China Principle was explicitly mentioned for the first time as a 'precondition' for the ROC's invitation to participate in the WHA (deLisle 2016, 552). Because Tsai Ing-wen and the ruling DPP refused to affirm the One-China Principle, the ROC's participation in the WHA has been suspended since 2017. Referring to the ROC's participation in the WHA, a PRC white paper published in 2000 stated that 'everything can be discussed under the One-China Principle' (Chu 2000, 62). In other words, if the ROC accepts the One-China Principle, 'all other issues regarding Taiwan's international status and international space can be discussed and [it is possible to] find solutions' (Chu 200o, 62). The way in which the PRC has determined the ROC's participation in the WHA arguably offers proof of the realist idea that international institutions, such as the WHO, are arenas for great powers to secure and advance their national interests.

\section{The ROC and the WHO During the COVID-19 Crisis}

The vulnerability of the WHO to great power influence is even more apparent during global health crises. After receiving news about patients falling sick with a mysterious unidentified form of pneumonia in Wuhan, the ROC's health officials directly contacted the WHO for more information. It also warned the organization on 31 December 2019 of the possibility of humanto-human transmission, referencing the International Health Regulations 
(IHR). However, the WHO only responded with a short message, stating that the information provided by the ROC had been forwarded to expert colleagues (Taiwan CDC 2020b). On 14 January 2020, the WHO wrote on the social media platform Twitter that there was 'no clear evidence' that the coronavirus could spread between people (Watt 2020). This Twitter post was made on the same day that the WHO's technical leader on COVID-19, Maria Van Kerkhove, gave a press briefing in Geneva warning of the potential for rapid spread. A middle-ranking WHO official had reportedly told the WHO's social media team to post a tweet that balanced the Van Kerkhove briefing, because the warning in this briefing conflicted with the initial Chinese findings (Corcoran 2020).

The WHO has also been accused of delaying the declaration of a Public Health Emergency of International Concern (PHEIC; Wenham et al. 2021, 1856). The designation of an outbreak as a PHEIC grants the WHO directorgeneral additional powers to issue recommendations for how countries should respond. While countries can ignore those directives, such an announcement can increase global attention to an outbreak. Such declarations are made when the outbreak poses a risk to more than one country and requires a coordinated international response. Nevertheless, the WHO did not declare the outbreak to be a PHEIC until the end of January. On 23 January, the same day that the PRC's central government announced a lockdown in Wuhan and two other cities, the WHO convened an emergency committee. The committee asserted that the coronavirus did not yet constitute a PHEIC and that the extent of human-to-human transmission was still unclear (WHO 2020). This was despite the widespread reporting of cases across Asia, with cases reported in Thailand on 13 January, in Japan on 16 January, in South Korea on 20 January, in Taiwan on 21 January, and Singapore and Vietnam on 23 January. It was only when the virus had spread to all provinces and major cities in the PRC on 30 January, that the WHO determined that the outbreak constituted a PHEIC.

Some commentators speculated that the WHO avoided declaring a PHEIC right after the Wuhan lockdown because it was concerned this would have been perceived by Chinese authorities as distrust of their capability to control the disease (Mazumdaru 2020). Officials at the WHO were also aware that angering the PRC leaders over the ROC could result in Chinese officials sharing less information with the international community or barring WHO experts from investigating the origins of the virus (Mazumdaru 2020). Despite the fact that the WHO praised the PRC in public, it has been reported by the media that officials privately complained that the PRC authorities were not sharing enough data to allow them to assess how effectively the 
virus spread between people or what risk it posed to the rest of the world (The Associated Press 2020).These political calculations, and the desire not to upset the PRC, has arguably meant that the WHO has downplayed the issue of the ROC 's participation during the current crisis.

This has been despite the fact that, during the early stages of COVID-19, the ROC led the world as the most-prepared and best-equipped region to fight the pandemic. The ROC authorities began screening passengers arriving from Wuhan as they disembarked at the airport on the same day that they first sent inquiries about COVID-19 to the WHO. The ROC also officially activated its Central Epidemic Command Center (CECC) on 20 January. This has allowed coordination with various ministries to enact policies and strategies already in place before the first case was reported on Taiwanese soil on 21 January (Taiwan CDC 2020a). At a time when other countries were experiencing a severe shortage of medical equipment, the ROC government implemented a rationing system for the public, allowing National Health Insurance cardholders to buy two masks per week at designated pharmacies. This number of masks was later increased to three per week, then nine every fortnight, after which an online ordering system was introduced (Taiwan CDC 2020c). When global infections reached one million in April 2020, the ROC government launched the Mask Donation Scheme that allowed Taiwanese people to donate their quota of surgical face masks to other countries that were in short supply. Taiwan likewise pledged to donate ten million face masks to different countries, including EU member states and the US (Peel and Hille 2020).

During the first year of the COVID-19 pandemic, the ROC was very successful in handling the virus. By the end of January 2021, only eight people in Taiwan had died from COVID-19 and it had seen a total of just 911 cases (JHU CSSE 2021). These statistics have been compared by some commentators with those of the PRC, which saw more than 89,500 cases of COVID-19. In making this comparison, some have also pointed to differences between the ROC's democratic approach to handling the pandemic and the authoritarian approach of the PRC. Therefore, the success that the ROC has had without WHO membership has increased international support for ROC membership in the organization (Lynch 2020). Supporters claimed that the WHO's exclusion of the ROC is seen to have prevented it from effectively sharing its strategy and information.

Trust in the WHO's objectivity on the matter has increasingly been eroded. This has been worsened by negative international media coverage. For example, during an interview with Radio Television Hong Kong (RTHK), the reporter Yvonne Tong asked the assistant director-general of the WHO, 
Bruce Aylward, a question about the ROC not being granted membership of the WHO. Aylward responded by claiming not to hear the question, with some commentators suggesting that he was pretending not to hear it and was refusing to discuss the ROC's participation (Watt 2020). When he was asked the same question again, he replied: 'we've already talked about China' (Watt 2020).

There have been accusations that the WHO is being influenced by the PRC. One Japanese minister, for example, said that the WHO should be renamed as the 'Chinese Health Organization (CHO)'. Meanwhile Facebook users renamed the WHO as the 'Winnie (the Pooh) Health Organization', referring to Chinese President Xi, who has been compared to Winnie the Pooh in online memes. Critics have also accused the director-general of the WHO of serving Chinese interests in responding to COVID-19 because of his personal connections with China, or the China connections of the Ethiopian government with which he is linked. The current director-general of the WHO, Tedros Adhanom Ghebreyesus, was Ethiopia's Minister of Foreign Affairs from 2012 to 2016. During his tenure, an electrified Ethiopia-Djibouti railway line was built by China Railway Group and China Civil Engineering Construction, with the PRC's Exim Bank financing $70 \%$ of the construction costs (BBC News 2016). The line connects to Djibouti, which houses the first and only PRC military base overseas. A connection between the PRC and Ethiopia can similarly be seen in the fact that the former director-general of the WHO, the Chinese-Canadian Margaret Chan, supported Tedros in the selection process of the new director-general. Although these facts do not necessarily mean that the WHO has fallen prey to Chinese influence, they create suspicions at a time when public trust in the organization is faltering.

\section{Escaping the 'Realist Trap': the Future of the ROC's Participation in Global Health Governance}

Recent years have seen the suspension of the ROC's invitation to participate in the WHA and the consequent exclusion of Taiwan from the WHO. Alongside this, the ROC's international space has been further dwindling as a number of its diplomatic partners have switched allegiance to the PRC (Ministry of Foreign Affairs, Republic of China, 2020). Taiwan had fifteen diplomatic partners at the time of writing. In the global health regime, given the vulnerability of the WHO to great power influence, it seems that there is little the ROC can do but to accept reality. The PRC is a rising economic and military power and it is also a greater source of global 
health threats. This means that the WHO and other international health organizations will likely choose the PRC over the ROC, in order to keep the former engaged in international cooperation. With the ROC's current international status, it seems that achieving 'meaningful participation' in global health governance is near to impossible in the absence of statehood (Chen 2018, 264). This chapter, however, argues the opposite. Owing to its de facto status, in its participation in global health governance the ROC is able to overcome two main constraints that realists claim that states face in international cooperation, namely free-rider and non-compliance problems (these constraints are here referred to as the 'realist trap').

Free-rider Problem: From a realist perspective, states see no obligation to help other states unless doing so will further their own national interests. National governments may provide public goods nationally, but there are few incentives for national governments to provide public health goods for other countries (Ng and Ruger 2011, 10). The provision of public health goods hence becomes the business of the hegemon (with the current global hegemon being the US; Min 2003, 23). While the hegemon provides public goods from which all other states benefit, its 'rivals' do not contribute to providing these goods. They therefore enjoy a 'free-ride' owing to the non-excludable nature of these goods or the fact that the hegemon cannot stop even those non-contributing states from receiving them (Min 2003, 23). Nobody is willing to pay unless there is a mechanism (i.e., taxation and fines) to enforce contribution. In this sense, realists argue that the US is reducing its contribution to global public goods to avoid the long-term relative decline of its hegemonic power. The cuts to US funding of Development Assistance for Health, the Global Health Security Agenda, and The President's Emergency Plan for AIDS Relief programmes under the Trump administration are cases in point.

Non-compliance Problem: A second constraint on global health cooperation is the way in which states can claim state sovereignty to justify non-compliance with norms in global health governance (Stevenson and Cooper 2009, 1379). Fighting the spread of viruses without international cooperation can be nearly impossible. Therefore, to fight viruses, states have to cede sovereignty to a certain extent in specific cases to ensure adequate provision of health security as a global public good (Huang 2016). From a realist perspective, states fear losing sovereignty, and in an anarchical international system they might only be willing to make a 'discount on sovereignty' when it comes to pragmatic problem solving (Florini 2011, 30).

Neither of these two constraints on cooperation apply to the ROC. As a de facto state, ROC officials want to gain sovereignty and international 
recognition. Therefore, the ROC's leaders have been acting as though it is a member state that is responsible for paying for public health goods and for compliance with the norms that form the global health regime. As part of the international community's response to the outbreak of Ebola in West Africa in 2014, for instance, the ROC government donated US\$1 million to international aid efforts and provided 100,000 sets of personal protective equipment for use by medical workers (Mainland Affairs Council, Republic of China 2015). Despite not being a WHO member state, the ROC has signed agreements with countries seeking help in overcoming the coronavirus, including the US. The ROC authorities announced the donation of two million surgical masks to the US.

The ROC has also contributed to disease control and mitigation at the regional level. For example, it organized training workshops for Asia-Pacific and Southeast Asian health professionals to improve the regional capacity to detect and respond to dengue fever, Ebola, Middle East Respiratory Syndrome (MERS), and Zika virus (Lee and Fang 2016). The ROC's commitment to health governance at the regional level is likewise shown by the 'New Southbound Policy' that the Tsai administration established. This policy strengthened the ROC's relationships with the ten countries of ASEAN, six states in South Asia (India, Pakistan, Bangladesh, Nepal, Sri Lanka, and Bhutan), Australia, and New Zealand (Taipei Economic and Cultural Office in Brunei Darussalam 2016). The ROC announced that six medical centres would be established in India, Indonesia, Malaysia, the Philippines, Thailand, and Vietnam to promote medical cooperation (Department of Information Service, Executive Yuan 2018). Escaping the realist fate, the ROC shows it can meaningfully participate in global health governance even in the absence of state-affiliated membership of the WHO.

\section{Concluding Remarks}

The ROC is one of the 'theatres' of the souring relations between the PRC and the US. In March 2020, the then US president Trump signed the Taipei Act requiring Washington to advocate the ROC's inclusion in international bodies like the WHO (Watt 2020). Furthermore, the then US Health Chief Alex Azar made a rare trip to the ROC. He was the highest-level American official to visit the ROC in decades (Wong 2020). All this posturing towards the ROC is a violation of the One-China Principle in the eyes of the PRC government. Considering the suspension of the ROC's participation in the 
WHA, plus the de facto status of the ROC, a realist perspective would argue that its contribution to and involvement in global health governance have to be minimal and limited. However, as this chapter shows, the de facto status helps the ROC escape this supposed 'realist trap', namely the free-rider and non-compliance problems that rational-choice theorists believe state actors face in global health governance. As long as the ROC upholds the provision of public health goods and compliance to global norms, it can achieve meaningful participation in health governance at both the global and regional levels.

\section{Acknowledgement}

I want to thank Yow Shuning for helping me with the data collection. Any errors remain my own.

\section{References}

BBC News. 2016. 'Ethiopia-Djibouti Electric Railway Line Opens.' 5 October. Accessed 30 October 2020. https://www.bbc.com/news/world-africa-37562177.

Chen, Ping-Kuei. 2018. 'Universal Participation without Taiwan? A Study of Taiwan Participation in the Global Health Governance Sponsored by the World Health Organization.' In Asia Pacific Security Challenge: Managing Black Swans and Persistent Threats, Anthony J. Masys and Leo S.F. Lin (eds.): 263-282. Cham: Springer International Publishing AG.

Corcoran, Kieran. 2020. 'An Infamous WHO Tweet Saying there Was 'No Clear Evidence' COVID-19 Could Spread between Humans Was Posted for 'Balance' to Reflect Findings from China.' Business Insider, 18 April. Accessed 20 January 2021. https://www.businessinsider.nl/who-no-transmission-coronavirus-tweet-wasto-appease-china-guardian-2020-4?international=true\& $\mathrm{r}=\mathrm{US}$.

Davenport, Andrew. 2011. 'Marxism in IR: Condemned to a Realist fate?' European Journal of International Relations vol. 19: 27-48.

DeLisle, Jacques. 2016. ‘Taiwan's Quest for International Space: Ma's Legacy, Tsai's Options, China's Choice, and U.S. Policy.' Orbis vol. 60: 550-574.

Department of Information Services, Executive Yuan. 2018. 'Taiwan Promotes Medical Cooperation with New Southbound Countries.' 14 June. Accessed 22 October 2020. https://english.ey.gov.tw/News_Content2.aspx?n=8262ED7A 25916ABF\&sms=DD07AA2ECD429oA6\&s=E924412CDo9CD1Co.

Florini, Ann. 2011. 'Rising Asian Powers and Changing Global Governance.' International Studies Review vol. 13: 24-33. 
Gilsinan, Kathy. 2020. 'How China Deceived the WHO.' The Atlantic, 12 April. Accessed 22 October 2020. https://www.theatlantic.com/politics/archive/2020/04/ world-health-organization-blame-pandemic-coronavirus/609820/.

Glaser, Bonnie S. 2013. 'Taiwan's Quest for Greater Participation in the International Community.' A Report of the CSIS Freeman Chair in China Studies, November. Accessed 20 January 2021. https://csis-website-prod.s3.amazonaws.com/s3fspublic/legacy_files/files/publication/131121_Glaser_TaiwansQuest_WEB.pdf.

Glaser, Charles. 2003. 'Structural Realism in a Complex World.' Review of International Studies vol. 29: 403-414.

Health and Human Services. 2020. 'HHS Secretary Azar Signs Joint Statement with Taiwan Minister of Health and Welfare.' 10 August. Accessed 30 October 2020. https://www.hhs.gov/about/news/2020/08/10/hhs-secretary-azar-signs-jointstatement-taiwan-minister-health-and-welfare.html.

Hickey, Dennis Van Vranken. 2007. Foreign Policy Making in Taiwan: From Principle to Pragmatism. London and New York: Routledge.

Huang, Yan Zhong. 2016. 'Taiwan's WHA Status in Limbo.' Forbes, 27 April. Accessed 16 November 2020. http://www.forbes.com/sites/yanzhonghuang/2016/04/27/ taiwans-wha-status-in-limbo/\#5are5eb7af55.

JHU CSSE. 2021. 'COVID-19 Data Repository by the Center for Systems Science and Engineering (CSSE) at Johns Hopkins University.' 31 January. Accessed 31 January 2021. https://github.com/CSSEGISandData/COVID-19.

Lee, Kelley, and Jennifer Fang. 2016. 'Challenges and Opportunities for Taiwan's Global Health Diplomacy.' Brookings, 10 May. Accessed 30 October 2020 . https://www.brookings.edu/opinions/ challenges-and-opportunities-for-taiwans-global-health-diplomacy/.

Li, Chien-pin. 2006. 'Taiwan's Participation in Inter-Governmental Organizations: An Overview of Its Initiatives.' Asian Survey vol. 46: 597-614.

Mainland Affairs Council, Republic of China. 2015. President Ma's Remarks. 6 November. Accessed 2 April 2021. https:/www.mac.gov.tw/en/News_Content.as px?n=FE07F9DA122E29D4\&sms=3A4E63FA5107487D\&s=CF95F21DEAFEE794. Mazumdaru, Srinivas. 2020. 'What Influence does China Have over the WHO?' DW, 17 April. Accessed 3o October 2020. https://www.dw.com/en/ what-influence-does-china-have-over-the-who/a-53161220.

Mearsheimer, John J. (1994/1995). The False Promise of International Institutions. International Security 19: 5-49.

Min, Byoung Won. 2003. 'Understanding International Hegemony: A Complex Systems Approach.' Journal of International and Area Studies vol. 10: 21-40.

Ministry of Foreign Affairs, Republic of China. 2020. 'Minister Vows no Fewer Diplomatic Allies in Tsai's Second Term.' 21 May. Accessed 3 April 2021. https:// www.roc-taiwan.org/sk_en/post/2268.html. 
Ng, Nora Y. and Jennifer Prah Ruger. 2011. 'Global Health Governance at a Crossroads.' Global Health Governance vol. 3: 1-37.

Peel, Michael, and Kathrin Hille. 2020. 'Taiwan to Donate 1om Masks to Europe and US', Financial Times, 1 April. Accessed 16 November 2020. https://www.ft.com/ content/e47a8cf4-786d-4367-a589-054a6a198840.

Stevenson, Michael, and Andrew F. Cooper. 2009. 'Overcoming Constraints of State Sovereignty: Global Health Governance in Asia.' Third World Quarterly vol. 30: 1379-1394.

Taipei Economic and Cultural Office in Brunei Darussalam. 2016. 'The Guidelines for "New Southbound Policy".' 23 August. Accessed 16 November 2020. https:// www.roc-taiwan.org/bn_en/post/644.html.

Taiwan Centers for Disease Control. 2020a. 'Central Epidemic Command Center (CECC) Raises Travel Notice Level for Wuhan, China to Level 3: Warning.' 21 January. Accessed 30 October 2020. https://www.cdc.gov.tw/En/Bulletin/ Detail/pVg_jRVvtHhp94C6GShRkQ?typeid=158.

- 202ob. 'The Facts Regarding Taiwan's Email to Alert WHO to Possible Danger of COVID-19.' 1 April. Accessed 17 November 2020. https://www.cdc.gov.tw/En/ Bulletin/Detail/PAD-lbwDHeN_bLa-viBOuw?typeid=158.

—. 2020c. 'Name-Based Rationing System for Purchases of Masks to be Launched on February 6; Public to Buy Masks with their (NHI) Cards.' 2 April. Accessed 30 October 2020. https://www.cdc.gov.tw/En/Bulletin/Detail/ZlJrIunqRjM49L IBn8p6eA?typeid $=\mathbf{1 5} 8$.

Taiwan News. 2018. 'Taiwan, Indonesia Hold $6^{\text {th }}$ Bilateral Meeting to Further New Southbound Policy.' 17 July. Accessed 30 October 2020. https://www.taiwannews. com.tw/en/news/3484332.

The Associated Press. 2020. 'China Delayed Releasing Coronavirus Info, Frustrating WHO.' 3 June. Accessed 30 October 2020. https://apnews.com/article/3co61794 970661042b18d5aeaaedgfae.

Watt, Louise. 2020. 'Taiwan Says It Tried to Warn the World about Coronavirus. Here's What it Really Knew and When.' TIME, 19 May. Accessed 17 November 2020. https://time.com/5826025/taiwan-who-trump-coronavirus-covidig/.

Wenham, Clare, Matthew Kavanagh, Alexandra Phelan, Simon Rushton, Maike Voss, Sam Halabi, Mark Eccleston-Turner, and Mara Pillinger. 2021. 'Problems with Traffic Light Approaches to Public Health Emergencies of International Concern.' The Lancet vol. 397: 1856-1858.

Winkler, Sigrid. 2012. Taiwan's UN Dilemma: To Be or Not To Be. Brookings, 20 June. Accessed 4 April 2021. https://www.brookings.edu/opinions/ taiwans-un-dilemma-to-be-or-not-to-be/.

Wong, Chun Han. 2020. 'U.S. Health Chief Praises Taiwan's Covid-19 Success, Irks Beijing in Rare Visit.' The Wall Street Journal, 10 August. Accessed 30 October 2020. 
https://www.wsj.com/articles/u-s-health-chief-praises-taiwans-covid-19-successirks-beijing-in-rare-visit-11597065692.

World Health Organization (WHO). 2020. 'Statement on the First Meeting of the International Health Regulations (2005) Emergency Committee Regarding the Outbreak of Novel Coronavirus (2019-nCoV).' 23 January. Accessed 16 November 2020. https://www.who.int/news/item/23-01-2020-statementon-the-meeting-of-the-international-health-regulations-(2005)-emergencycommittee-regarding-the-outbreak-of-novel-coronavirus-(2019-ncov).

\begin{abstract}
About the Author
Catherine Yuk-ping LO is an Assistant Professor at University College Maastricht, Maastricht University. She specializes in international relations and global health. Her current research interests include HIV/AIDS in China and India, infectious disease responses in Northeast and Southeast Asian states, antimicrobial resistance (AMR) challenges in the Global South and North, and also global health diplomacy. She is the author of HIV/AIDS in China and India: Governing Health Security (Palgrave Macmillan, 2015). Her book won the 2017 International Studies Association (ISA) Global Health Section Book Prize. Her works appear in such journals as the Australian Journal of International Affairs, Health and Policy Planning, Globalization and Health, and the Journal of Global Security Studies.
\end{abstract}





\title{
$7 \quad$ From Pneumonia to Pragmatism
}

\author{
The Role of the WHO in Japan During Public Health \\ Emergencies
}

\author{
Anoma P. VAN DER VEERE
}

\begin{abstract}
Over the past three decades, Japan has faced multiple public health crises. This chapter examines the role of the World Health Organization (WHO) in the formulation of Japan's responses to the SARS, MERS, and COVID-19 public health crises. During these crises, the WHO was used as a neutral and scientific source of information and thus managed to influence Japan's responses. However, trust in the organization has faltered due to its connection with China. Japanese policymakers have questioned the neutrality of the organization. This chapter shows that the importance of the WHO in Japanese policymaking has declined and will continue to do so as long as the organization's neutrality is doubted, and as long as its advice and guidelines conflict with Japan's domestic agenda.
\end{abstract}

Keywords: Japan, World Health Organization (WHO), public health crises, domestic policymaking, national agenda, COVID-19

\section{Introduction}

This chapter examines the role of the World Health Organization (WHO) in the formulation of Japan's responses to the SARS, MERS, and COVID-19 public health crises. During these crises, the WHO was used as a neutral and scientific source of information, and thus managed to influence Japan's responses. However, trust in the organization has faltered due to its connection with China. Japanese policy makers have questioned the neutrality of the organization. This chapter argues that Japan has pragmatically balanced

\footnotetext{
Van der Veere, Anoma P., Florian Schneider, and Catherine Yuk-ping Lo (eds), Public Health in Asia during the COVID-19 Pandemic: Global Health Governance, Migrant Labour, and International Health Crises. Amsterdam, Amsterdam University Press 2022 DOI: 10.5117/9789463720977_CHO7
} 
declining trust in the organization with domestic policy aims, with these aims often taking precedence. It shows that the importance of the WHO in Japanese policymaking has declined and will continue to do so as long as the organization's neutrality is doubted, and as long as their advice and guidelines conflict with Japan's domestic agenda.

Although the scale of the SARS, MERS, and COVID-19 crises cannot be compared, the ways in which Japan has organized its national response to these three crises have followed similar patterns. During public health crises the Japanese cabinet establishes an ad hoc task force to formulate containment policies. Those policies directly related to health are implemented by the Ministry of Health, Labour, and Welfare (MHLW), while policies related to international traffic of people and goods are implemented by the Ministry of Foreign Affairs (MOFA) and the Ministry of Justice. The main scientific research centre in Japan dealing with emerging infectious diseases is the National Institute of Infectious Diseases (NIID). The NIID is tasked with cooperating with other national institutes and international organizations, and it reports back directly to the MHLW (NIID 2018). Informed officials at the MHLW are consequently involved in policy making through cooperation with the cabinet and parliamentary questioning in the Japanese National Diet.

The analysis in this chapter relies on official parliamentary records published during the three public health crises. I have included Diet meetings and MHLW public documents from 1 November 2002 to 31 July 2003 (SARS), 1 April 2014 to 31 December 2015 (MERS), and 1 December 2019 to 31 May 2020 (COVID-19) in the data set. I have collected records of the National Diet meetings from the National Diet database (National Diet Library n.d.).

\section{Japan and the World Health Organization}

\section{The 2003 SARS outbreak}

SARS was first identified in November 2002 in southern China, evolving into a global outbreak between February and July 2003 (WHO 2003, 81). Twenty-six countries were eventually affected and by 31 December 2003 there were 8096 infections and 774 fatalities (WHO 2015). The outbreak lasted several months and according to the WHO was eventually subdued as a 'result of monumental efforts on the part of governments and health care staff, supported by a well-informed and cooperative public' (WHO 2003a, 218). 
The WHO issued a global alert concerning 'cases of atypical pneumonia' on $12 \mathrm{March}(\mathrm{WHO} 2003 \mathrm{~b}$ ), with these later being identified as SARS. After this alert, regional quarantine stations in Japan started sending out information to medical institutions and the national Japan Medical Association about the possibility of a new infectious disease entering Japan. ${ }^{1}$ In the following months, travellers were warned of the risk of infection before departure, while incoming passengers from mainland China, Hong Kong, Taiwan, and Canada were required to report their health status and have their body temperature measured. Visitors from these countries and regions were also asked to self-quarantine for ten days after arrival (MHLW 2001, National Diet 2003b).

In response to the alert, the MHLW started formalizing patient reporting and collecting information concerning the infrastructural capacities of medical institutions (i.e. private rooms, negative pressure rooms; National Diet 2003c, National Diet 2003i). ${ }^{2}$ Over the course of the SARS outbreak both the incumbent administration, under the leadership of then-Prime Minister Koizumi Junichirō (former Minister of the MHLW 1996-1998), and the MHLW, consistently deferred to the standards and guidelines of the WHO in their response (National Diet 2003f). ${ }^{3}$

In late March 2003, the MHLW's leading expert, Takahara Ryōji (19472013), was called for questioning in the House of Representatives of the National Diet, Japan's main legislative body. He confirmed that the MHLW had implemented a standardized patient reporting system that followed the WHO's guidelines. He also frequently stated that Japanese laboratories, including the NIID, had engaged in cooperation with the WHO and research institutions abroad (National Diet 2003i, National Diet 2003). Takahara used the information that he had obtained from this cooperation with these institutions to inform the cabinet and members of parliament about the nature of the SARS virus. He clarified, for example, that human coronaviruses are the cause of SARS, and he repeatedly emphasized the

1 Quarantine stations are tasked with regulating incoming goods and passengers that pose a risk to public health. For an overview of Japan's quarantine stations, see: https://www.mhlw. go.jp/english/policy/health-medical/health/dl/contact_list_jqs.pdf.

2 In March 2003 there were 22 negative pressure rooms nationwide equipped to deal with SARS patients.

3 The MHLW officially stated that the WHO, together with UNAIDS, formed the two main pillars of Japan's international cooperation efforts in battling infectious diseases. See: MHLW, White Paper Heisei 15, page 346. In parliament, Minister of State Ōgi Chikage also stated that 'we will do our utmost to implement the domestic and international manuals designated by the WHO $[\ldots]$ so that we can continue to have no cases in Japan.' 
importance of the WHO's criteria in reporting new infections (National Diet 2003c, National Diet 2003).

Despite the testimony given by Takahara, members of the National Diet remained critical. They argued that the decentralization that had been carried out in previous years, especially under the Koizumi administration, had led to a laissez-faire approach to governance that extended to public health policy. They said this meant that during the SARS crisis local health institutions, such as quarantine stations, had to contact the MHLW on their own initiative when they faced possible cases of SARS (National Diet 2003a). In fact, local governments were tasked with creating their own responses when they encountered outbreaks of infection (National Diet 2003b). The responses from these local governments were therefore formulated on a case-by-case basis (National Diet 2003a). There were no clear national guidelines for the back-and-forth chain of command that was required when these responses were being formulated, further increasing the amount of time it took these local governments to respond to outbreaks of infection.

It was seen how officials relied on the WHO for information. This led to calls to set up a permanent, centralized, national task force that could allow Japan to deal with pandemics itself, instead of principally relying on the WHO (National Diet 2003b, National Diet 2003d). However, despite these calls, the MHLW instead set up an ad hoc task force (National Diet 2003b). As part of this task force, an emergency system remained in place during the SARS crisis (MHLW 2001). This emergency task force was dissolved once the immediate threat from SARS came to an end.

During the SARS crisis it became clear that Japan was not equipped to deal with a major outbreak (National Diet 2003a). Tokyo, for example, only had ten locations that were equipped to deal with SARS patients, despite it being the most populous metropolitan area in the world. The MHLW focused primarily on information distribution, rather than implementing concrete changes to Japan's medical infrastructure (MHLW 2001). There was no system in place to regulate the quarantining of incoming passengers, which essentially made this a voluntary procedure (National Diet 2003b). Consequently, opposition politicians continued to be critical of the lack of a streamlined national response and clear guidelines (National Diet 2003a).

The SARS crisis also incited fears about contaminated food crossing into Japan (National Diet 2003a, National Diet 2003g, National Diet 2003e). This was because of the way SARS came shortly after the world had encountered outbreaks of bovine spongiform encephalopathy, which is better known as mad cow disease. During the SARS crisis, Takahara was called in to parliament a second time. As with his earlier position, he deferred to the 
WHO and argued there was 'no epidemiological evidence that contact with objects or animals [had] led to human infection with SARS' (National Diet 2003g). Despite the way that sceptical opposition politicians called for stricter import regimes to avoid the entry of contaminated food, the cabinet supported Takahara's position. It used the conclusions reached by the WHO which Takahara had cited to justify its decision to keep import restrictions out of its response (National Diet 2003g, National Diet 2003h). Because the initial outbreak of SARS was located in China, which was and remains Japan's largest trade partner, an import blockade would have had disastrous consequences for the economy.

In fact, Japan made a gesture of goodwill during the SARS crisis by providing support to China. It sent out health experts and around eighteen million yen worth of medical supplies and instruments. This was despite a significant cooling of the bilateral relationship being seen at this time, which was the result of Koizumi's growing assertiveness, and some would argue hostility, towards China (Lam 2005). For a short period between April and May 2003, the SARS crisis dominated the bilateral relationship between the two countries (Przystup 2017). However, political distrust of China persisted. This was compounded by the way that Taiwan was excluded from the WHO as a result of China's interference, something which led to questions in Japan about the effectiveness of the WHO (National Diet 2003a). Distrust of China extended beyond the opposition in the Diet. For example, the Deputy Minister of the MHLW, Kimura Yoshio, suggested that the officially reported number of people infected in China did 'not reflect reality' (National Diet 2003g). However, restrictions on trade with China were blocked by the ruling cabinet. Bilateral lines of communication were eventually opened with the affected nations and regions, including Taiwan, to circumvent the WHO's limitations (National Diet 2003i). This indicated how Japan's response was pragmatic when its domestic needs superseded the limits of the WHO's collaborative framework.

\section{The 2014-2015 MERS threat}

MERS was discovered in 2012 (WHO 2019). There have been several different outbreaks of the virus affecting twenty-seven countries and leading to 2442 infections and 842 fatalities between 2012 and May of 2019 (Donnelly et al. 2019). The MERS outbreak among medical personnel in Saudi Arabia in 2014, although not leading to the WHO declaring an international public health emergency, did lead the WHO to make several emergency preparedness announcements directed at all member states (WHO 2014, WHO 2014a, WHO 
2014b). In response, in Japan the MHLW started sending out information to medical institutions in a similar way to that which it had done during the SARS crisis. Reporting of possible cases was formalized and a regional approach to decision-making was adopted (MHLW 2014). In short, in Japan the MERS response was a continuation, if not a duplication, of the SARS response.

In July 2014, the incumbent cabinet, under Prime Minister Abe Shinzō, officially designated MERS as an infectious disease under the Act on Prevention of Infectious Diseases and Medical Care for Patients with Infectious Diseases, which had been published in 1998 (MHLW 2014a). This designation of MERS meant that anyone entering Japan from an affected country who had a heightened body temperature, or who had been in contact with a confurmed MERS patient, had to report to the local quarantine station upon landing. Passengers who had visited any of the affected countries were also required to self-declare at the quarantine station upon arrival in Japan (MHLW 2017, National Diet 2015b). Those under suspicion of infection were required to take a PCR test (MHLW 2014b). The information concerning MERS symptoms, signalling, and which countries were affected, was taken from WHO reports (MHLW 2014c).

Throughout 2014, the MHLW mainly followed WHO guidelines in its response to MERS, following the International Health Regulations (IHR, for details see the introduction of this volume) that had been established in 2005 (National Diet 2015b). In a way similar to the response to the 2003 SARS crisis, the cabinet and the MHLW continued to focus on information distribution (National Diet 2014a).

Policy makers became increasingly alarmed following a major outbreak of MERS which occurred in South Korea in June 2015 (Park and Munroe 2015). This outbreak, which was labelled as a 'superspreading event', saw a single MERS patient infecting dozens of other people in the space of a few weeks (Kupferschmidt 2015, 1183). The WHO reviewed the incident and blamed it on a number of factors including South Korea's lack of medical expertise, its inadequate infection control measures, its admission of too many foreign visitors, as well as the practice of so-called 'doctor shopping' where patients visit various medical facilities in search of the right physician (WHO 2015a, National Diet 2015b). As a result of this, in the same month as the outbreak occurred in South Korea, the WHO released a risk assessment regarding MERS. This concluded that the outbreaks of MERS did not qualify as an international public health emergency (National Diet 2015b, WHO 2015b).

This announcement by the WHO was picked up in the Japanese National Diet. Its view that South Korea failed in its response to MERS was taken over ad 
verbatim by both the incumbent administration and the opposition (National Diet 2015b). However, due to South Korea's geographic proximity and its popularity as a tourist destination, worries remained about the virus 'slipping through the cracks' and crossing into Japan (National Diet 2015c). As a result, the Ministry of Foreign Affairs established contact with the health authorities in South Korea in order to gain insight into the movement of people suspected of infection. However, information about non-Japanese patients could not be collected through these means (National Diet 2015c) and could also not be obtained through the WHO. A general consensus formed in Japan that the information provided by the WHO was insufficient, particularly because this information did not track the movement of specific cases across borders and so made it difficult to prevent possible outbreaks (National Diet 2014).

Under these circumstances, the head of the MHLW's Health Bureau, Shinmura Kazuya, was called into parliament to clarify Japan's response to MERS. Restating the need for a regional approach, Shinmura attempted to solidify the existing status quo amid rising fears of a possible outbreak (National Diet 2014). Critical members of the opposition argued that the current approach would be insufficient in quelling a major outbreak, pointing to Japan's lack of medical infrastructure and local experts (National Diet 2015b). For example, Okamoto Mitsunori, the former Deputy Minister of the MHLW, called the response a 'just-in-time' game (National Diet 2015c).

Members of the opposition questioned the cabinet and the MHLW about Japan's capacity to treat patients and its transportation capabilities. Referring to an October 2014 survey, the Deputy Minister Nagaoka Keiko stated that 87 , out of 141 municipalities in Japan, had a total of 206 vehicles for transporting patients. For the other 54 municipalities, local networks had been established with fire departments and local governments to provide emergency transportation (National Diet 2015). Whether this number was sufficient to deal with a national outbreak was not discussed.

The head of the MHLW's Health Bureau, Shinmura, also said that there were 300 medical institutions with 1500 beds available for infected patients, and said that he believed this to be adequate (National Diet 2015b). However, he was forced to acknowledge the shortage of infectious disease experts in Japan, which had been a chronic issue for years. The National Center for Global Health and Medical Research had previously tried to educate more local experts, to no avail (National Diet 2014a). Consequently, the incumbent Minister of the MHLW, Shiozaki Yasuhisa, was also forced to acknowledge the shortage. He confirmed that in June 2015 only 1232 doctors were certified by the Infectious Diseases Society of Japan as specialists, a number well below national standards (National Diet 2015). 
There had been attempts to increase the number of experts in Japan by sending more people abroad through the WHO framework to gain experience in infectious diseases (National Diet 2014a, National Diet 2014). The concurrent outbreak of Ebola in Africa had been an opportunity to do so. However, instead of focusing on domestic policy goals and the MERS response, the cabinet viewed the Ebola outbreak as an opportunity to position itself as a regional leader. As a result, Japan mostly postured and sent few experts abroad, despite the fact that it was trying to 'train a large number of experts in infectious diseases' (National Diet 2015b). In the end, neither Japan's domestic shortcomings nor the limitations of the WHO's global information network were properly addressed during the MERS outbreaks seen in 2014.

\section{The 2020 COVID-19 pandemic}

The first case of COVID-19 in Japan was discovered on 14 January 2020 (MHLW 2020). Since then, the government has taken different steps to contain its spread, including information campaigns, public emergencies, and travel restrictions. The first concrete measure was taken on 21 January, when the Japanese government enacted travel restrictions for the Wuhan region of China where COVID-19 was first seen. At the time of writing, the pandemic has not been contained in Japan, so new measures continue to be taken. The Japanese government's decisions have been influenced considerably by international guidelines set by the WHO. However, Japan's approach has not been consistent. Domestic priorities have led policymakers to adopt a pragmatic approach in which the WHO's guidelines are used to legitimize various new policies, even when these policies are contradictory.

The then-Prime Minister Abe Shinzō was first questioned about Japan's COVID-19 response during discussions in the House of Representatives on 23 January 2020. During this questioning, Abe made reference to the emergency risk assessment meetings held by the WHO in order to argue for strengthened quarantine measures and for the need to prepare the national healthcare system (National Diet 202ol). However, few measures were taken in the early stages of the pandemic. Even though a combination of factors resulted in this slow response to COVID-19, criticism was aimed at Abe for prioritizing the Tokyo 2020 Olympic and Paralympic Games over addressing the newly emerging infectious disease (Kingston 2020).

The Tokyo 2020 Games were eventually postponed in late March. Whether the Games had a direct effect on Japan's lagged response remains debatable. Nevertheless, the fact remains that the cabinet was slow to implement concrete steps to address COVID-19. For example, in early 2020 Katō 
Katsunobu, then Minister of the MHLW stated only that the cabinet would 'continue to monitor the situation in Japan on a daily basis'. He consistently referenced the decision by the WHO to refrain from designating the disease an emergency and the government's compliance with WHO guidelines (National Diet 2020d). The initial assessment of COVID-19 by the WHO, and its decision to refrain from designating the disease as a public health emergency of international concern (PHEIC), legitimized the incumbent cabinet's restrained response during the first weeks of the pandemic (WHO 2020, National Diet 2020r).

From 20 January 2020, the MHLW started publicly reporting on COVID-19 via their website. However, these reports contained updates on the development of the disease rather than practical policies (MHLW 2020a). As well as their criticism about the lack of an immediate response, throughout January and February, members of the Diet also criticised this limited flow of information to the public. Diet members questioned the government's ability to counter unreliable information about COVID-19, or what was labelled an 'infodemic' in reference to the WHO's public warning against the spread of inaccurate information without a scientific basis (National Diet 2020n, WHO 2020a).

Surprisingly, some of this early criticism came from within the ruling party. One member of the Liberal Democratic Party (LDP) openly questioned why no permanent administrative body had been set up. They asked why it was necessary for a new task force to be formed during each public health crisis. Pressed on the matter, the Minister of the MHLW at the time, Katō, acknowledged the deficiencies of the (regional) approach that the MHLW had taken during earlier public health threats. He stated that the government was setting up a new collaborative framework with the NIID and relevant agencies and ministries to formulate a national response (National Diet 2020d). However, on 31 January, in response to the WHO's official designation of COVID-19 as a public health emergency of international concern (or PHEIC; WHO 202ob), another emergency task force was established to address the developing pandemic (National Diet 2020f). Although set up under the auspices of the National Security Council, a cabinet-led body charged with national security issues, the task force dealing with the pandemic was established separately, in stopgap fashion. The establishment of this task force therefore continued the practice of creating ad hoc emergency task forces to deal with public health emergencies (National Security Council 2020).

The announcement by the WHO that COVID-19 was a public health emergency of international concern (PHEIC) hastened Japan's designation of 
the virus as an infectious disease (National Diet 2020f, National Diet 2020u). This enabled the Japanese government to enact the Infectious Disease Law in order to implement pandemic policies. Nevertheless, the expert meeting that would serve as the scientific basis for the national approach was held on 14 February. According to the former opposition leader Saitō Renhō, who was head of the Constitutional Democratic Party, this was a month and a half too late (National Diet 2020 g). In fact, no concrete and coordinated national policy was formulated. The central government effectively delegated responsibility for the containment of infections to prefectural and municipal governments, without providing a national framework for local governments to fall back on, something which left national coordination in a fractured state (Van der Veere 2020). This lack of central governance coincided with decreasing public trust in the WHO, further debilitating an already fragile COVID-19 response.

Only a few days after the WHO announced that COVID-19 was a PHEIC, Watanabe Shū (Constitutional Democratic Party of Japan) publicly expressed doubts about the neutrality of the WHO. Referencing an article from the French newspaper Le Monde, he asked Kato what his opinion was on the possibility that the WHO had refrained from designating COVID-19 in this way because of pressure from China. He went as far as to suggest that the WHO Director-General Tedros Adhanom Ghebreyesus was under strong Chinese influence because of the fact that his home country of Ethiopia had hosted a Chinese-built African Union building and had long been the recipient of major Chinese investments. Katō, in turn, refused to engage with the subject, falling back on the need for international cooperation (National Diet 2020s, National Diet 2020h).

Generally, officials from the various ministries, in particular the MHLW and MOFA, as well as cabinet members, refrained from answering critical questions concerning the WHO. The WHO's guidelines consistently served as justification for many of the policies implemented in later months. The MHLW obtained its information primarily from WHO reports, particularly data concerning the spread of COVID-19 in China (National Diet 2020n, National Diet 2020w).

The estimate made by the WHO about COVID-19's incubation period also led Japan to adopt a fourteen-day quarantine rule (National Diet 202ot). This quarantine measure was then adopted for passengers of the Diamond Princess Cruise ship (National Diet 20200). Passengers were locked on the ship for weeks while government workers attempted to track and trace the spread of the virus among them only to catch it themselves due to a lack of proper protective measures and without proper government support. 
When Katō was asked by Saitō why passengers were eventually allowed to disembark despite the potential health risk, he cited passenger complaints and a 'certain amount of evidence and professional judgement', rather than relying on factual evidence (National Diet 2020g).

The Japanese government was heavily criticized by several countries, the media, and the WHO, for its mishandling of the case (National Diet 20200, National Diet 2020v, Rich and Yamamitsu 2020). Nevertheless, Katō repeatedly stated that the WHO's guidelines were being followed and that the occurrence of four new infections among MHLW staff was simply 'unfortunate' (National Diet 202op). The case of the Diamond Princess exemplifies the way in which the WHO's advice and guidelines served as justification for specific measures, even when this required a flexible interpretation of these guidelines.

The cabinet and Ministry of Foreign Affairs (MOFA) set up stringent travel bans, ignoring the WHO Director General's public warning that widespread travel bans were not necessary (Nebehay 2020). The director of the Immigration Department and Immigration Control Office attempted to justify the travel bans by arguing they were a direct result of the way the WHO had designated COVID-19 a PHEIC (National Diet 2020m), even while the WHO publicly criticized this policy (Nikkei 2020).

The issue of nationwide closure of schools also illustrates the pragmatic approach that Japan has taken to following the WHO guidelines. While cabinet members claimed that the WHO advocated a 'multi-sectoral approach' that justified closing schools, members of the opposition pointed to a lack of evidence that schools formed clusters for infections and argued that transmission from children to adults had yet to be confirmed (National Diet 2020g). LDP representative Koga Yūichirō later used the same 'evidence' to challenge claims that children were less of an infection risk, pointing to the way in which the coronavirus spread mainly among households (National Diet 2020). In fact, the WHO had recommended school closures, whilst also stating that this was a 'political choice'. Although members of the opposition in the Diet pointed this out, Abe was consistent in deferring to the recommendation as a legitimate reason for closing schools (National Diet 202ob).

However, this pragmatic approach to following WHO guidelines had to be balanced with a growing distrust of the WHO in Japan. In early March 2020, the WHO announced that South Korea, Italy, Iran, and Japan were considered its 'greatest coronavirus concerns'. This announcement touched a nerve among Japanese politicians, especially as China was left out of the list (Nebehay 2020a). There were immediate calls for the WHO 
Director-General Tedros to resign as he was seen as 'unfit' for his position. One ruling party member openly questioned why Japan was contributing so much to the WHO and buying so little influence, while in contrast China was 'able to exert a huge amount of influence with a small amount of money' (National Diet 2020j).

Although the cabinet and officials attempted to refrain from directly criticizing the WHO, this was not always successful. One high official let slip that he believed that Tedros had shown China too much consideration (National Diet 2020v), while Deputy Prime Minister and Minister of Finance Asō Tarō went a step further by calling the WHO a 'suspicious organization', saying there were calls to rename it the 'Chinese Health Organization' (National Diet 2020i). Unsurprisingly, there was little resistance in the National Diet to subjecting the WHO to an independent review, a resolution pushed by Japan during the $73^{\text {rd }}$ World Health Assembly in May 2020. The only issue that split the ruling party from the opposition was the timing of the review: during or after the pandemic (National Diet 2020c).

The issue of Taiwan's participation in the WHO gradually became a symbol of these concerns. In 2016, following the election of the anti-Beijing Tsai administration in Taiwan, China successfully pressured the WHO into barring Taiwan's participation in the World Health Assembly, the organization's annual meeting. This remained the situation at the start of the COVID-19 pandemic (Kassam 2020). Although 29 countries petitioned for Taiwan's participation as an observer during the assembly in May 2020, it was still unable to join. Japan took the public position that 'there should be no geographical gaps in global health' and continued lobbying, although with little effect (National Diet 2020c). In the Japanese National Diet this was interpreted as a lack of Japanese influence and also seen as an indication of a strong Chinese presence in the WHO (National Diet 2020e, National Diet 2020k).

The Japanese government is therefore actively lobbying for high positions within the WHO to increase its influence (National Diet 2020i, National Diet 2020q). This is not to say that Japan has little sway over the WHO. The Abe administration already enjoyed a strong relationship with the WHO before the pandemic. Abe published an opinion piece in the Washington Post co-authored with Tedros arguing that 'all nations should have universal health care' (Abe and Ghebreyesus 2019). In early February 2020, Abe also boasted about the fact that Japan had already dispatched health experts via the WHO to countries with fragile medical systems (National Diet 2020t). Moreover, the WHO immediately granted an MHLW request that cases related to the Diamond Princess cruise ship were listed separately from Japanese domestic cases in WHO global communications (National 
Diet 2020v). Despite the WHO's initial criticism of Japan's approach to the pandemic, when Japan complained about its inclusion in the 'greatest coronavirus concerns' list, these complaints gained a prompt exhortatory response from the WHO, Tedros, and the UN Secretary-General António Guterres (National Diet 2020a).

Nevertheless, the distrust of the WHO persisted. As Kokuba Kōnosuke, the incumbent Chief Secretary of the LDP, remarked, 'Japan should not only rely on the WHO,' but should strengthen its own capabilities in countering emerging infectious diseases (National Diet 2020v). The ruling cabinet was forced to balance its reliance on the WHO and an increasing distrust of the organization. It did this by exerting pressure wherever the WHO's information directly contradicted domestic policies. The cabinet largely refrained from criticizing the WHO and its information, while also agreeing with the general talking points produced by the opposition (questioning the WHO's neutrality and mentioning Chinese influence, Taiwan, and the independent review). In this way, the cabinet was able to rely on the WHO to justify domestic policies while also not directly contradicting the increasing distrust expressed in the National Diet.

\section{Conclusion}

Japan has been confronted with several public health emergencies over the course of the $21^{\text {st }}$ century. One consistent factor during each outbreak was the role of the WHO as a mechanism for providing information and guidelines. However, the distrust of China seen during the SARS crisis became a distrust of the WHO's neutrality during the COVID-19 pandemic. It was already clear during the 2014-2015 MERS outbreak that there were domestic shortcomings in Japan's ability to handle such infectious diseases, including a chronic deficit of local experts on infectious diseases, and also that there was a limit to the information the WHO could provide. However, unrelated domestic priorities often took precedence over responding to the public health threats, leaving these issues unaddressed. Japan's eventual decision to bypass the WHO's information network during the MERS outbreak, by directly establishing contact with Taiwan and other affected countries and regions, further weakened the WHO's standing in public health policy making.

This prioritization of the domestic agenda became apparent once again during the COVID-19 pandemic. The WHO's guidelines and information were not followed strictly, but used pragmatically, and only when they coincided with domestic policy goals. The continued reliance on ad hoc 
task forces in all three public health emergencies covered in this chapter, despite calls for a permanent one, is a clear example of this prioritization. Moreover, the distrust of China, and by extension the WHO, worsened over the course of the COVID-19 pandemic. This worsening distrust is evidenced by the pragmatism with which Japan followed WHO guidelines. It is also symbolized by Japan's support of Taiwan's participation in the World Health Assembly and calls for an independent review of the WHO's functioning. In conclusion, the WHO's importance in Japan's policy making has declined since the SARS crisis in 2003. It will continue to decline unless the WHO's guidelines and advice coincide with Japan's domestic agenda, and unless policy makers are assured of its neutrality.

\section{References}

Abe, Shinzo, and Tedros Adhanom Ghebreyesus. 2019. 'Opinion: All nations should have Universal Health Care.' The Washington Post, 12 December 2019. https://www. washingtonpost.com/opinions/global-opinions/all-nations-should-have-universalhealth-care/2019/12/12/9594269c-1c47-11ea-8d58-5ac36oog67a1_story.html.

Donnelly, Christl A., Mamun R. Malik, Amgad Elkholy, Simon Cauchemez, and Maria D. Van Kerkhove. 2019. 'Worldwide Reduction in MERS Cases and Deaths since 2016.' Emerging Infectious Diseases 9, no. 25: 1758-176o. https:// doi.org/10.3201/eid2509.190143.

Kassam, Natasha. 2020. 'As Wuhan Virus Spreads, Taiwan Has No Say at WHO.' Foreign Policy, 22 January 2020. https://foreignpolicy.com/2020/01/22/ china-health-coronavirus-wuhan-virus-spreads-taiwan-no-say-who/.

Kingston, Jeff. 2020. 'Abe Prioritized Olympics, Slowing Japan's Pandemic Response.' The Asia-Pacific Journal:Japan Focus 18, no. 7: 1-8. https://apjjf.org/Jeff-Kingston/5387/article.pdf.

Kupferschmidt, Kai. 2015. 'Amid Panic, a Chance to Learn about MERS.' Science 348, no. 6240:1183-1184. https://doi.org/10.1126/science.348.6240.1183.

Lam, Peng Er. 2005. 'Japan's Deteriorating Ties with China: The Koizumi Factor.' China: An International Journal 3, no. 2: 275-291. https://doi.org/10.1353/ chn.2005.0023.

MHLW. 2001. 'Jūshō kyūsei kokyū kishō kōgun (SARS) kanren jōhō (Severe Acute Respiratory Syndrome (SARS) Related Information).' Tōkyō, January. https:// www.mhlw.go.jp/bunya/kenkou/kekkaku-kansenshouo5/o6-07.html.

—. 2014. 'Chūtō kokyū-ki shōkōgun (MERS) ni kan suru taiō ni tsuite (kyōryoku irai) (Concerning the Response to the Middle East Respiratory Syndrom (MERS) 
(Cooperation Request)).' 16 May 2014. https://www.mhlw.go.jp/bunya/kenkou/ kekkaku-kansenshou19/dl/20140516_01.pdf.

—. 2014a. 'Chūtō kokyū-ki shōkōgun o shitei kansen-shō to shite sadameru-tō no seirei no shikō-tō ni tsuite (Concerning the Enforcement of Government Ordinances including the Designation of the Middle East Respiratory Syndrome as a Designated Infectious Disease).' 16 July 2014. https://www.mhlw.go.jp/ bunya/kenkou/kekkaku-kansenshou19/dl/20140716_03.pdf.

—. 2014b. 'Chūtō kokyū-ki shōkōgun ni okeru ken'eki taiō ni tsuite (Concerning the Quarantine Measures Response to the Middle East Respiratory Syndrome).' 24July 2014. https://www.mhlw.go.jp/bunya/kenkou/kekkaku-kansenshourg/ dl/20140724_01.pdf.

—. 2014c. 'Ken'eki-hō dai 2-jō dai 3-gō ni kitei suru ken'eki kansen-shō (Infectious Diseases Quarantine Provision Quarantine Law Article 2, Section 3).' 24 July 2014. https://www.mhlw.go.jp/file/o6-Seisakujouhou-109ooooo-Kenkoukyoku/oooo171026.pdf.

—. 2017. 'Chūtō kokyū-ki shōkōgun (MERS) ni tsuite (Concerning the Middle East Respiratory Syndrome). 7 July 2017. https://www.mhlw.go.jp/stf/seisakunitsuite/ bunya/kenkou/kekkaku-kansenshou19/mers.html.

-.2020. 'Shingata koronauirusu ni kanren shita haien no kanja no hassei ni tsuite (1 reime) (Concerning Patient Infections Associated with the Novel Coronavirus (1st case)).' Tōkyō, 16 January 2020.

—. 2020a. 'Chūkajinminkyōwakoku Kohoku-shō Bukan-shi ni okeru shingata koronauirusu kanren haien ni tsuite (dai-5-pō) (Concerning the Pneumonia Related to the Novel Coronavirus in Wuhan City, Hubei Province, China ( $5^{\text {th }}$ Report)).' 20 January 2020. https://www.mhlw.go.jp/stf/newpage_08998.html. National Diet. 2003. 156 Sangiin honkaigi 19-gō (19th Plenary Session of the 156th House of Councillors). Tōkyō, 23 April 2003.

-. 2003a. $15^{6}$ Sangiin kōsei rōdō iinkai 15-gō (15th Meeting of the 156th House of Councillors Public Welfare and Labour Committee). Tōkyō, 22 May 2003.

—. 2003b. 156 Sangiin kōsei rōdō iinkai 16-gō (16th Meeting of the House of Councillors Public Welfare and Labour Committee). Tōkyō, 27 May 2003.

-. 2003c. ${ }_{15} 6$ Sangiin kōsei rōdō iinkai 4-gō (4th Meeting of the 156 th House of Councillors Public Welfare and Labour Committee). Tōkyō, 26 March 2003.

-. 2003d. 156 Sangiin naikaku iinkai 7-gō (7th Meeting of the 156 th House of Councillors Cabinet Committee). Tōkyō, 8 May 2003.

—.2003e. 156 Sangiin naikaku iinkai, kōsei rōdō iinkai, nōrin suisan iinkai rendō shinsakai 1-gō (1st Meeting of the 156th House of Councillors Cabinet, Public Welfare and Labour, Agriculture, Forestry and Fisheries Combined Inspection Committee). Tōkyō, 14 May 2003. 
-. 2003f. 156 Shūgiin kessan gyōsei kanshi iinkai dai-yon bunkakai (1st Meeting of the 156th House of Representatives Fourth Monitoring of Administrative Financial Settlement Committee). Tōkyō, 19 May 2003.

—. 2003g. $15^{6}$ Shūgiin kōsei rōdō iinkai 10-gō (10th Meeting of the 156th House of Representatives Public Welfare and Labour Committee). Tōkyō, 18 April 2003. - . 2003h. 156 Shūgiin kōsei rōdō iinkai 12-gō (12th Meeting of the 156th House of Councillors Public Welfare and Labour Committee). Tōkyō, 7 May 2003.

-. 2003i. 156 Shūgiin kōsei rōdō iinkai 4-gō (4th Meeting of the 156th House of Representatives Public Welfare and Labour Committee). Tōkyō, 19 March 2003. - 2014. 187 Sangiin kōsei rōdō iinkai 7-gō (7th Meeting of the 187th House of Councillors Public Welfare and Labour Committee). Tōkyō, 4 November 2014. - 2014a. 187 Shūgiin kōsei rōdō iinkai 7-gō (7th Meeting of the 187th House of Representatives Public Welfare and Labour Committee). Tōkyō, 13 November 2014. -. 2015. 189 Sangiin kōsei rōdō iinkai 21-gō (21st Meeting of the 189th House of Councillors Public Welfare and Labour Committee). Tōkyō, 14 July 2015.

-. 2015a. 189 Shūgiin kōsei rōdō iinkai 13-gō (13th Meeting of the 189th House of Representatives Public Welfare and Labour Committee). Tōkyō, 13 May 2015.

- 2015b. 189 Shūgiin kōsei rōdō iinkai 27-gō (27th Meeting of the 189th House of Representatives Public Welfare and Labour Committee). Tōkyō, 1 July 2015.

-.2015c. 189 Shūgiin yosan iinkai 19-gō (19th Meeting of the 189th House of Representatives Budget Committee). Tōkyō, 18 June 2015.

-.2020. 201 Sangiin naikaku iinkai 4-gō (4th Meeting of the 201st House of Councillors Cabinet Committee). Tōkyō, 13 March 2020.

- 2020a. 201 Sangiin seifu kaihatsu enjō-tō ni kan suru tokubetsu iinkai ( $5^{\text {th }}$ Meeting of the 201st House of Councillors Special Committee regarding Development Assistance and etcetera). Tōkyō, 29 May 2020.

-.202ob. 201 Sangiin yosan iinkai 11-gō (11th Meeting of the 201st House of Councillors Budget Committee). Tōkyō, 16 March 2020.

-.2020c. 201 Sangiin yosan iinkai 17-gō (17th Meeting of the 201st House of Councillors Budget Committee). Tōkyō, 29 April 2020.

-. 2020d. 201 Sangiin yosan iinkai 1-gō (1st Meeting of the 201st House of Councillors Budget Committee). Tōkyō, 29 January 2020.

-.2020e. 201 Sangiin yosan iinkai 2-gō (2nd Meeting of the 201st House of Councillors Budget Committee). Tōkyō, 30 January 2020.

-. 2020f. 201 Sangiin yosan iinkai 3-gō (3rd Meeting of the 2o1st House of Councillors Budget Committee). Tōkyō, 31 January 2020.

-. 2020g. 201 Sangiin yosan iinkai 4-gō (4th Meeting of the 201st House of Councillors Budget Committee). Tōkyō, 2 March 2020.

-. 2020h. 201 Sangiin yosan iinkai kōchōkai 1-gō (1st Public Hearing of the 201st House of Councillors Budget Committee). Tōkyō, 10 March 2020. 
-. 2020i. 201 Sangiin zaimu kinyū iinkai 7-gō (7th Meeting of the 201st House of Representatives Financial Affairs Committee). Tōkyō, 26 March 2020.

-.2020j. 201 Shūgiin gaimu iinkai 2-gō (2nd Meeting of the 201st House of Representatives Foreign Affairs Committee). Tōkyō, 6 March 2020.

-. 2020k. 201 Shūgiin gaimu iinkai 8-gō (8th Meeting of the 201st House of Representatives Foreign Affairs Committee). Tōkyō, 20 May 2020.

- 2020l. 201 Shūgiin honkaigi 3-gō (3rd Plenary Session of the 201st House of Representatives). Tōkyō, 23 January 2020.

—. 2020m. 201 Shūgiin kokudo kōtsū iinkai 2-gō (2nd Meeting of the 201st House of Representatives Land, Infrastructure and Transport Committee). Tōkyō, 6 March 2020.

-. 2020n. 201 Shūgiin yosan iinkai 11-gō (11th Meeting of the 201st House of Representatives Budget Committee). Tōkyō, 12 February 2020.

- 20200. 201 Shūgiin yosan iinkai 14-gō (14th Meeting of the 201st House of Representatives Budget Committee). Tōkyō, 19 February 2020.

-. 2020p. 201 Shūgiin yosan iinkai 16-gō (16th Meeting of the 201st House of Representatives Budget Committee). Tōkyō, 26 February 2020.

-. 2020q. 201 Shūgiin yosan iinkai 18-gō (18th Meeting of the 201st House of Representatives Budget Committee). Tōkyō, 28 February 2020.

-. 2020r. 201 Shūgiin yosan iinkai 3-gō (3rd Meeting of the 201st House of Representatives Budget Committee). Tōkyō, 28 January 2020.

-.2020s. 201 Shūgiin yosan iinkai 5-gō (5th Meeting of the 201st House of Representatives Budget Committee). Tōkyō, 3 February 2020.

—. 2020t. 201 Shūgiin yosan iinkai 6-gō (6th Meeting of the 201st House of Representatives Budget Committee). Tōkyō, 4 February 2020.

-. 2020u. 201 Shūgiin yosan iinkai 8-gō (8th Meeting of the 201st House of Representatives Budget Committee). Tōkyō, 6 February 2020.

—. 2020v. 201 Shūgiin yosan iinkai dai-nana bunkakai 1-gō (1st Meeting of the 201st House of Representatives Budget Committee 7 th Subcommittee). Tōkyō, 25 February 2020.

-. 2020w. 201 Shūgiin zaimu kinyū iinkai 3-gō (3rd Meeting of the 201st House of Representatives Financial Affairs Committee). Tōkyō, 14 February 2020.

National Diet Library. n.d. 'Kokkai kaigiroku kensaku shisutemu.' https://kokkai. ndl.go.jp/.

National Security Council). 2020. 'Kokkai anzen hoshō kaigi (National Security Council).' Shūshō kantei (Prime Minister's Office of Japan). Accessed 30 January 2021. https://www.kantei.go.jp/jp/singi/anzenhosyoukaigi/kaisai.html.

Nebehay, Stephanie. 2020a. 'South Korea, Iran, Italy and Japan Are Greatest Virus Concern: WHO.' Reuters, 3 March 2020. Accessed 30 December 2020. https:// www.reuters.com/article/us-health-coronavirus-who-tedros-idUSKBN20P2FQ. 
- 2020. 'WHO chief says widespread travel bans not needed to beat China virus.' Reuters, 3 February 2020. Accessed 30 December 2020. https://www.reuters. com/article/us-china-health-who-idUSKBN1ZX1H3.

NIID. 2018. 'Kokuritsu kansenshō kenkyūjo / National Institute for Infectious Diseases.' Tokyo.

Nikkei. 2020. 'WHO Slams Japan and South Korea's Tit-for-tat Travel Curbs.' Nikkei Asia, 7 March 2020. Accessed 30 December 2020. https://asia.nikkei.com/Spotlight/ Coronavirus/WHO-slams-Japan-and-South-Korea-s-tit-for-tat-travel-curbs.

Park, Ju-min, and Tony Munroe. 2015. 'South Korea Reports Third MERS Death as Alarm Grows.' Reuters, 4 June 2015. Accessed 30 December 2020. https://www. reuters.com/article/us-health-mers-southkorea-idUSKBNoOJ2Y420150604.

Przystup, James J. 2017. 'Japan-China Relations: Political Breakthrough and the SARS Outbreak.' Comparative Connections: 1-10. http://cc.pacforum.org/wp-content/ uploads/2017/o6/o302qjapan_china.pdf.

Rich, Motoko, and Eimi Yamamitsu. 2020. 'Hundreds Released From Diamond Princess Cruise Ship in Japan.' The New York Times, 19 February 2020. Accessed 30 February 2020. https://www.nytimes.com/2020/02/19/world/asia/japancruise-ship-coronavirus.html.

Van der Veere, Anoma P. 2020. 'Japan's Fragmented Response: Technology, Governance, and COVID-19.' In How Asia Confronts COVID-19 through Technology, Florian Schneider and Rogier Creemers (eds.):, 5-14. Leiden: LeidenAsiaCentre. WHO. 2003. 'Severe Acute Respiratory Syndrome (SARS).' Weekly Epidemiological Record 78, no. 12: 81-88. https://www.who.int/wer/2003/wer7812/en/.

- 2003a. 'Severe Acute Respiratory Syndrome (SARS): Over 100 Days into the Outbreak.' Weekly Epidemiological Record 78, no. 26: 217-228. https://www.who. int/wer/2003/wer7826/en/.

- 2003b. 'WHO Issues a Global Alert about Cases of Atypical Pneumonia.' Geneva, 12 March 2003. Accessed 16 February 2021. https://www.who.int/csr/ sars/archive/2003_03_12/en/.

-. 2014. 'Middle East Respiratory Syndrome Coronavirus (MERS-CoV) Summary and Literature Update.' 9 May 2014. Accessed 16 February 2021. https://www.who. int/csr/disease/coronavirus_infections/MERS_CoV_Update_09_May_2014.pdf.

—. 2014a. 'Emergencies Preparedness, Response: Middle East Respiratory Syndrome Coronavirus (MERS-CoV) - Saudi Arabia.' 16 October 2014. Accessed 16 February 2021. https://www.who.int/csr/don/16-october-2014-mers/en/.

- 2014b. 'Emergencies Preparedness, Response: Middle East Respiratory Syndrome Coronavirus (MERS-CoV) - Saudi Arabia.' 7 November 2014. Accessed 16 February 2021. https://www.who.int/csr/don/o7-november-2014-mers/en/.

- 2015. Summary of Probable SARS Cases with Onset of Illness from 1 November 2002 to 31 July 2003.' 24 July 2015. Accessed 10 August 2020. https://www. 
who.int/publications/m/item/summary-of-probable-sars-cases-with-onset-ofillness-from-1-november-2002-to-31-july-2003.

- 2015a. 'WHO Statement on the Ninth Meeting of the IHR Emergency Committee Regarding MERS-CoV.' 17 June 2015. Accessed 16 February 2021. https://www. who.int/mediacentre/news/statements/2015/ihr-ec-mers/en/.

—. 2015b. 'Middle East Respiratory Syndrome Coronavirus (MERS-CoV): Summary and Risk Assessment of Current Situation in Korea and China.' 3 June 2021. Accessed 16 February 2021. https://www.who.int/docs/default-source/documents/ emergencies/health-topics---mers/mers-cov-republic-of-korea-and-china-riskassessment-3-june-2015.pdf?sfvrsn=6co9gabb_1.

—. 2019. 'Middle East Respiratory Syndrome Coronavirus (MERS-CoV).' 11 March 2019. Accessed 16 February 2021. https://www.who.int/news-room/ fact-sheets/detail/middle-east-respiratory-syndrome-coronavirus-(mers-cov). -. 2020. 'Statement on the First Meeting of the International Health Regulations (2005) Emergency Committee Regarding the Outbreak of Novel Coronavirus (2019-nCoV).' Geneva, 23January 2020. Accessed 16 February 2021. https://www. who.int/news/item/23-01-2020-statement-on-the-meeting-of-the-international-health-regulations-(2005)-emergency-committee-regarding-the-outbreakof-novel-coronavirus-(2019-ncov).

-. 2020a. 'Novel Coronavirus (2019-nCoV) Situation Report.' 2 February 2020. Accessed 16 February 2021. https://www.who.int/docs/default-source/coronaviruse/ situation-reports/20200202-sitrep-13-ncov-v3.pdf.

-. 202ob. WHO Director-General's Statement on IHR Emergency Committee on Novel Coronavirus (2019-nCoV). 30 January 2020. Accessed 16 February 2021. https:/www.who.int/director-general/speeches/detail/who-director-generals-statement-on-ihr-emergency-committee-on-novel-coronavirus-(2019-ncov).

\section{About the Author}

Anoma Phichai VAN DER VEERE is a Researcher of Modern Asia within the Leiden Asia Centre at Leiden University, and a Research Fellow at the IAFOR Research Center at the Osaka School of International Public Policy. He is currently based at Osaka University, Japan, and has published on health and labour policy, sports, technology, and human rights in Asia and Europe. His latest publications include: 'Japan's Fragmented Response: Technology, Governance, and COVID-19' (Leiden Asia Centre, 2020), 'The Tokyo Paralympic Superhero: Manga and Narratives of Disability in Japan' (Asia Pacific Journal:Japan Focus, 2020), and 'The Technological Utopia: Mimamori Care and Family Separation in Japan' (AsiaScape: Digital Asia, 
2019). He is currently the principal investigator in the Road to Tokyo 2020 project about local policymaking in disability sports in Tokyo in the run-up to the 2020 Olympic and Paralympic Games, and the 'Understanding the Limitations and Future of Transnational Migrant Labor and Global Health Governance in Asia' project, both funded by the Leiden Asia Centre. 


\section{PART III}

Domestic Responses to COVID-19

in a Globalized Asia 



\title{
8 The COVID-19 Pandemic
}

\author{
Socio-Economic Issues, Health Care, Health Security and \\ the Rapid Response in Vietnam
}

Anh Tuyet NGUYEN

\begin{abstract}
The COVID-19 pandemic has significantly impacted healthcare systems and health security in lower- and middle-income countries. In Vietnam the number of infections and deaths has remained relatively low compared to other countries owing to an early and aggressive response. Nevertheless, the impacts on vulnerable groups in Vietnam have been severe. This chapter discusses the socio-economic impacts of COVID-19 on healthcare and health security in Vietnam by focusing on economically disadvantaged groups and the elderly, thereby showing that despite Vietnam's relatively successful response to COVID-19 during 2020, it remains necessary to provide social support to those who are most vulnerable during public health crises.
\end{abstract}

Keywords: health security, Vietnam, COVID-19, social support, healthcare systems, early response

\section{Introduction}

COVID-19 is a pandemic and global public health crisis that has had significant socio-economic impacts. In particular, the healthcare systems and health security in lower- and middle-income countries have become strained. In Vietnam, owing to an early and aggressive response, the number of infections and deaths has remained relatively low when compared to other countries. Nevertheless, the impacts on vulnerable groups in Vietnam have been severe.

\footnotetext{
Van der Veere, Anoma P., Florian Schneider, and Catherine Yuk-ping Lo (eds), Public Health in Asia during the COVID-19 Pandemic: Global Health Governance, Migrant Labour, and International Health Crises. Amsterdam, Amsterdam University Press 2022 DOI: 10.5117/9789463720977_CH08
} 
This chapter argues that the early response and strict policies in $\mathrm{Vi}$ etnam limited the spread of COVID-19 during 2020. An examination of Vietnam's response alongside the World Health Organization's (WHO) response and the guidelines it issues shows that Vietnam was pro-active in its response, and was ahead of the curve in the early stages of the global pandemic. However, this chapter also discusses the socio-economic impacts of COVID-19 on healthcare and health security in Vietnam. It describes the national healthcare challenge the country now faces. By focusing on economically disadvantaged groups and the elderly, the chapter argues that despite Vietnam's relatively successful response to COVID-19 during 2020, it remains necessary to provide social support to those who are most vulnerable during public health crises such as the COVID-19 pandemic.

Vietnam has a population of just over 97 million and shares a border with China, where the COVID-19 pandemic originated (Worldometer 2020a). The first case of COVID-19 in Vietnam was reported on 23 January 2020. As of 22 September 2020, Vietnam had reported 1068 confirmed COVID-19 cases and 35 related deaths (Ohya 2020). In terms of total number of cases, in April 2020 the Worldometer (2020b) ranked Vietnam 172 out of 221 COVID-19 affected countries and territories. Of the 35 COVID-related deaths in Vietnam that had occurred by the autumn of $2020,65 \%$ were people aged 60 and over (ThuVienPhapLuat 202ob).

The effects of COVID-19 in Vietnam during 2020 can be divided into two waves (see Figure 8.1). The first wave occurred between 23 January and 25 June 2020. The number of confirmed cases reached $35^{2}$ and no deaths were reported in this period (DaNang Today 2020). In the second wave, the coastal city of Danang became the epicentre of COVID-19 outbreaks in Vietnam. In response to this, the Vietnamese government implemented fifteen days of lockdown measures on 28 July in Danang. Only essential services, such as pharmacies, hospitals, and supermarkets were allowed to open (Bohane 2020). While the future remains hard to predict, during 2020 Vietnam proved to be successful in handling the COVID-19 pandemic.

The Vietnamese central government has sought to actively prevent the spread of COVID-19. At the onset of the outbreak, the authorities framed the virus as 'a common foreign enemy' through various directives (Ha Son Thai 2020, see also Le and Nicolaisen chapter in this volume). This message conveyed that the whole nation needed to be ready 'to fight' against COVID-19 (Ha et al. 2020, 2). The authorities carried out proactive quarantine of close contacts, as well as aggressive contact tracing, to minimize the rapid spread of the virus (CDC 2020). The government also tracked infected people (recognized as ' $F_{o}$ ' patients), individuals who had direct or indirect 
Figure 8.1 The Number of Confirmed and Daily New Confirmed COVID-19 Cases in Vietnam

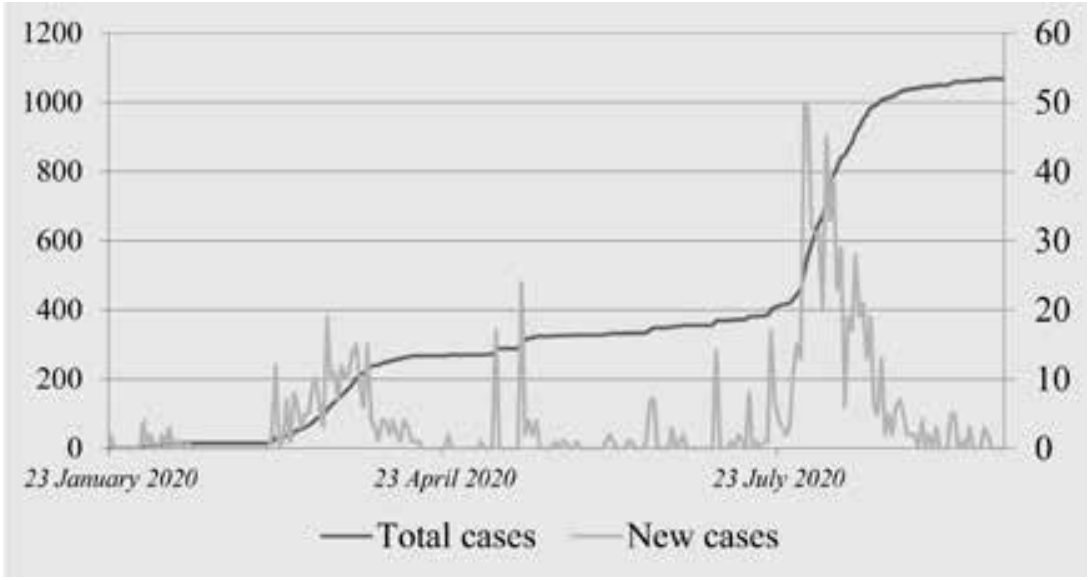

Source: European CDC-Last updated 22 September 2020

contact with $\mathrm{F}_{\mathrm{o}}$ patients, as well as suspected cases (recognized as $\mathrm{F}_{1}, \mathrm{~F}_{2}$ [close contact with $F_{1}$ ], all the way up to $F_{3}$ ), all of whom were required to report to their local Medical Centre (Thuvienphapluat 2020a; DaNang Today 2020). Such local Medical Centres, and specifically the grassroots health system in Vietnam, have played an important role as a first line of defence during the COVID-19 pandemic. The Vietnamese health care system consists of four administrative levels: the central level, provincial level, district level, and commune level (Takashima et al. 2017, 2). By the end of 2019, the number of health insurance enrolments in Vietnam had reached nearly 86 million people, making up $89 \%$ of the country's population (Anh Kiet 2020). Notably, these health care facilities have a strong focus on disease prevention, and rely on grassroots health networks that include approximately 700 district hospitals and over 8000 community health stations (Tran, Bach Xuan et al. 2020, 2). During the COVID-19 pandemic, these grassroots establishments have provided health education on preventive measures for residents at the community and district levels. They have provided information to individuals who have had close contact with COVID-19 patients and to those who have returned from areas where the pandemic had taken hold. These establishments provided guidance to individuals throughout medical procedures and identified local quarantine points or facilitated home isolation with medical checks, providing referrals to specialists when needed (Ha et al. 2020, 3).

At the same time as dispensing information in this way the Vietnamese government has also implemented other COVID-19 related measures. It restricted 
travel, suspending all international flights. It also closed schools at an early stage and shut down non-essential service facilities. All health facilities, agencies, and unions in the country acted together to prevent the spread of COVID-19 within the community (Ministry of Health 2020b). Although those containment measures have helped to protect the lives and health of Vietnamese citizens, they have also resulted in a massive reduction in economic activities, as discussed below (ILO 2020). In other words, for Vietnam the pandemic has not only presented a global public health crisis but also a socio-economic crisis that has seriously affected economically disadvantaged groups, including the elderly.

This chapter looks at how Vietnam responded to the early emergence of COVID-19 alongside the ways in which the WHO was responding to the virus at the same time. This chapter uses Vietnam's handling of COVID-19 as a case study to compare Vietnam's response with that of the WHO. This analysis aims to show that Vietnam implemented early and strict policy responses during different stages of the outbreak. In addition, this chapter discusses the socioeconomic impacts of COVID-19 on healthcare and health security. It details the national healthcare challenges Vietnam faces as a result of the pandemic.

\section{The Vietnamese Government's Response to the COVID-19 Pandemic and the WHO's Response Plan}

The COVID-19 pandemic has created an unprecedented challenge for global healthcare systems. During the pandemic, the WHO has been a central figure leading disease preparedness and responses worldwide. In the early stage of the global outbreak, Vietnam quickly recognized the devastating nature of the pandemic. It began to prepare for the outbreak even before it had recorded its first case (Trevisan, Le, and Le 2020; BBC News 2020).

The strict policies enacted by the Vietnamese government were generally put in place before the WHO issued its recommendations, especially in the initial stages of the global outbreak (see Table 8.1; United Nations 2020). Ha and colleagues $(2020 \mathrm{~b})$ have argued that Vietnam's limited financial and technological resources would have been exhausted by a huge number of infected patients. Vietnam therefore had an urgent need to take rapid and strict measures. Vietnam has been affected by a number of different viruses in the past, including Severe Acute Respiratory Syndrome (SARS), the so-called 'avian flu' or Influenza $\mathrm{AH}_{5} \mathrm{~N} 1$, and Influenza A subtype $\mathrm{H}_{5} \mathrm{~N} 6$ (USAID 2020). Because of these previous experiences and lessons learned in containing these viruses, the Vietnamese government has pooled its resources to create a more resilient healthcare system. 
Table 8.1 A summary timeline of nationally implemented policies in Vietnam and the WHO's recommendation and response plan

\begin{tabular}{|c|c|}
\hline Timeline with Vietnam's response plan & Timeline with WHO's response plan \\
\hline \multirow{3}{*}{$\begin{array}{l}9 \text { Jan: Ministry of Health }(\mathrm{MOH}) \text { warns of } \\
\text { mysterious pneumonia in China (Nhandan } \\
\text { News 2020). }\end{array}$} & $\begin{array}{l}5 \text { Jan: The WHO issued the first outbreak } \\
\text { news report (WHO 2020c). }\end{array}$ \\
\hline & \multirow[b]{2}{*}{$\begin{array}{l}11 \text { Jan: The WHO publishes a comprehen- } \\
\text { sive COVID-19 commodity package. }\end{array}$} \\
\hline & \\
\hline $\begin{array}{l}16 \text { Jan: The MOH issued Decision No. 125/ } \\
\text { QD-BYT on the first guidelines for diagnosis } \\
\text { and treatment of coronavirus infections } \\
\text { (MOH 2020d). }\end{array}$ & $\begin{array}{l}\text { 'The mode(s) of transmission of the } n C o V \text { are } \\
\text { currently unknown. Available information } \\
\text { suggests that the } n \text { CoV is zoonotic and causes } \\
\text { infections in humans through contact with } \\
\text { infected animals (to be confirmed). Current } \\
\text { data suggests that there is no or limited } \\
\text { human-to-human transmission' (WHO 2020f). }\end{array}$ \\
\hline $\begin{array}{l}28 \text { Jan: The Prime Minister signs Directive } \\
\text { No. 05/CT-TTg on the prevention and } \\
\text { control of the Coronavirus outbreak, which } \\
\text { immediately requests the establishment of a } \\
\text { Rapid Response Team and also requests that } \\
\text { the Ministry of Health reports daily on the } \\
\text { situation to the Prime Minister. }\end{array}$ & \\
\hline $\begin{array}{l}29 \text { Jan: The } \mathrm{MOH} \text { issues Guidelines about } \\
\text { the supervision of people in close contact } \\
\text { with CoV confirmed cases and those who } \\
\text { returned from pandemic areas (Ministry of } \\
\text { Transport 2020). }\end{array}$ & \\
\hline $\begin{array}{l}30 \text { Jan: } M O H \text { issues Decision No. } 255 / Q Đ+D- \\
\text { BYT on the establishment of Rapid Response } \\
\text { Teams (MOH 2020e). }\end{array}$ & \\
\hline $\begin{array}{l}\text { The Prime Minister issues Decision No. } \\
\text { 170/QD-TTg on establishment of National } \\
\text { Steering Committee for controlling the } \\
\text { outbreak. }\end{array}$ & \\
\hline
\end{tabular}




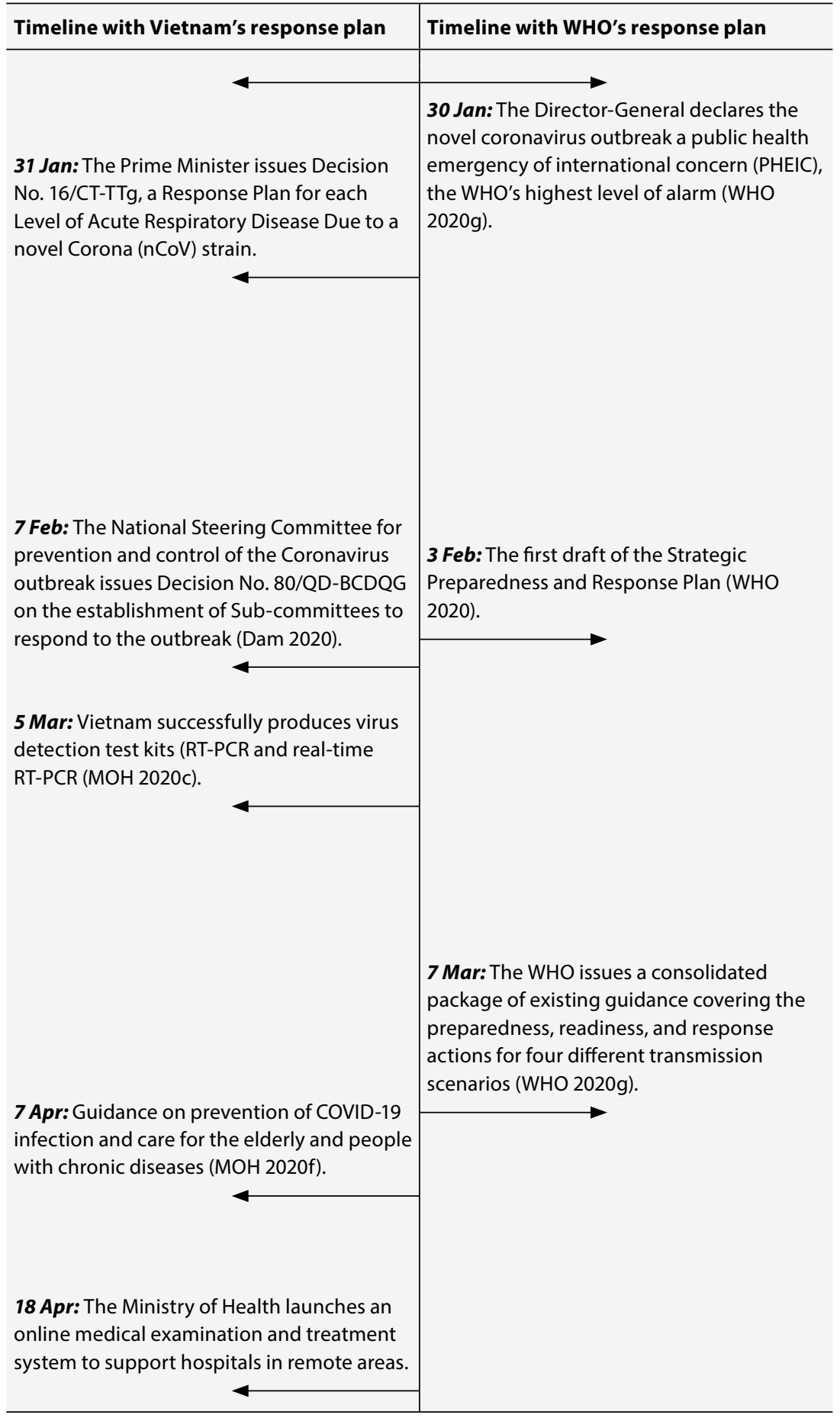




\begin{tabular}{l|l}
\hline Timeline with Vietnam's response plan & Timeline with WHO's response plan \\
\hline & $\begin{array}{l}\text { 9 Jul: The WHO Director-General announced } \\
\text { the co-chairs of the Independent Panel } \\
\text { for Pandemic Preparedness and Response } \\
\text { (IPPR) to evaluate the world's response to } \\
\text { the COVID-19 pandemic (WHO 2020a). }\end{array}$ \\
\cline { 2 - 2 } & $\begin{array}{l}\text { 23 Jul: Guidance on COVID-19 for the care of } \\
\text { elderly people (WHO 2020b). }\end{array}$ \\
for COVID-19 pandemic prevention. & \\
\hline
\end{tabular}

On 16 January, during the early days of the outbreak in China, the Vietnamese Ministry of Health issued guidelines for the diagnosis and treatment of coronavirus infections ( $\mathrm{MOH}$ 2020d). Vietnam recorded its first cases on 23 January. Shortly after, on 30 January, the Vietnamese government stepped up its response by organizing the National Steering Committee on Epidemic Prevention (Phuc 2020b). This was the same day when the WHO declared the outbreak a Public Health Emergency of International Concern (PHEIC; WHO 2020f). In response to increasing concern about vulnerable groups, on 9 April, the government issued guidelines on how to prevent and manage COVID-19 infections and how to care for the elderly and people with chronic diseases (MOH 2020f). Three months later, on 23 July, the WHO published additional guidelines on the care of elderly people living in long-term care and other non-acute care facilities, as well as guidelines on home care (WHO 2020b).

National responses to the COVID-19 pandemic vary between countries as a result of different socio-economic contexts, healthcare systems, and the political party in power at the time (Han et al. 2020; Boin, Lodge, and Luesink 2020). The positive outcomes in Vietnam can therefore be attributed to the rapid response and precautions taken by the government in the early stages of the pandemic.

\section{The Socio-Economic Impact of COVID-19}

Although containment measures have helped to protect the lives and health of Vietnamese citizens, these measures have also resulted in a massive reduction in economic activities (Monitor 2020). The socio-economic impact of the COVID-19 pandemic is likely to be more severe for economically 
disadvantaged groups and the elderly in two ways: (1) an increase in poverty that makes the already vulnerable worse off, and (2) an increase in socioeconomic inequalities that will lead to increased health and food insecurity.

Although Vietnam's economy has been less affected than other countries, the economic impact of the pandemic has still been significant. According to the Statistics Office of Vietnam, the country's GDP grew 1.81\% in the first half of 2020, the lowest grow th rate since 2010 (General Statistics Office 2020a). In addition, about 35 million workers do not have social insurance, particularly those working in the agriculture and informal sectors (Nation 2020). For workers who are involved in production, a sector that heavily relies on imports, UNICEF has predicted that poverty rates would increase from $18 \%$ to $31 \%$ (UNICEF 2020 ).

The outbreak thus threatens access to basic essential services among these segments of society and negatively affects their already vulnerable livelihoods (Nation 2020). These economically disadvantaged groups have also been hard-hit by rising out-of-pocket expenditures, which have in turn been exacerbated by a loss of income because of confinement and isolation (P. B. Tran et al. 2020). In the first half of 2020 , around 66,500 people across the country suffered from food shortages, showing a sharp increase of $74.6 \%$ compared to the same period in the previous year (General Statistics Office 2020a).

The pandemic has also had a serious impact on the elderly in Vietnam. More than $60 \%$ of elderly people aged 60 to 69 , and $30 \%$ percent of those aged 70 to 79 , are still working. The majority of elderly workers in Vietnam $(81 \%)$ are informal workers (Vietnam Women Union 2012). The informal labour force, such as self-employed household businesses, motorbike and taxi drivers, and farmers, has been the group most severely affected by COVID-19. It accounts for the majority of the workforce in four out of five of the sectors that have been hit hardest (HelpAge 202 ob). In addition, a large proportion of elderly people in Vietnam are reliant on the support of their children (32\%; Vietnam Women Union 2012). With more than $86 \%$ of businesses negatively affected by COVID-19, the financial support by children for elderly parents is expected to decline (General Statistics Office 202ob).

In response to increasing concerns about vulnerable people during the pandemic, the Vietnamese government issued a US $\$ 2.6$ billion relief package for cash support from April to June 2020 (Vietnam News 2020). In addition, the authorities have planned an expanded fiscal package to strengthen the national health systems and provide financial support for the most vulnerable and impoverished ( $\mathrm{MOH}$ 2020a). Specifically, the Minister of Planning and Investment has discussed a support package for people in 
difficulties due to the COVID-19 pandemic of 62,00o billion Vietnamese dong (approximately US $\$ 2.6$ million). About 20 million people are expected to receive support through this (K. Nguyen 2020).

\section{The Impact of COVID-19 on Health Care}

COVID-19 has disrupted health and health services in Vietnam in different ways. For example, the loss of daily earnings and the need for social distancing have led to economic and psychological stress. This loss may also increase levels of domestic violence (UNICEF 2020). In a recent study in Vietnam, a high proportion of respondents said they had suffered symptoms of psychological stress during the first national lockdown (Le et al. 2020). Notably, being unemployed or retired was connected to a higher score of intrusion and hyperarousal related to negative emotions, which means people had increased trouble sleeping and concentrating.

The pandemic occurred in a period of already growing mental health issues among more vulnerable population sectors in Vietnam. The fact that the country has a weak mental health system with few mental health policies in place has led to an ineffective action plan for addressing this problem (Vietnam News 2020). In response to increasing mental health concerns during the pandemic, the Ministry of Health has issued guidelines for mental health care in the context of the COVID-19 pandemic (MOH 2020i). However, it remains critical for Vietnam to formulate an effective strategy for the screening of psychological problems and the implementing appropriate interventions, especially among high-risk groups, such as the elderly.

Older people in Vietnam have experienced higher levels of psychological distress during the COVID-19 pandemic (Le et al. 2020). The elderly (above 60 years) are also at a higher risk of suffering serious illnesses or COVID-19 related deaths (ThuVienPhapLuat 202ob). Elderly people in Vietnam are more likely to live in larger households and less likely to live in nursing homes; only about $0.6 \%$ of the elderly live in long-term care facilities (General Statistics Office 2020a). Stay-at-home orders are potentially harmful for elderly people because they threaten to increase the potential for violence, abuse, or neglect (HelpAge 2020a). In addition, the need for social distancing has made the elderly's ongoing healthcare difficult.

Moreover, many elderly people have refrained from consulting their doctors for check-ups and treatments because of a fear of infection (Gharib 2020). Healthcare services have only been provided for urgent cases $(\mathrm{MOH}$ 2020c). The provision of home check-up services is only available in big 
cities, such as Ho Chi Minh City and Hanoi. Payment is also an issue, as home check-ups are only covered by health insurance for those who are over the age of 80 , or those who already have serious health problems. This has meant that people over 60 who are in need of healthcare have had to rely on family carers, who typically have little or no training. The situation has been exponentially worse for those living alone (Age International 2020).

There is therefore an urgent need to collect data about access to essential services, particularly about access to social and health services among the most vulnerable groups. The grassroots health system provides primary health care services (Ha et al. 2020b). This health system, namely district-based health centres, also plays an important role as a first-line defence during medical emergencies, such as the COVID-19 pandemic (B. $\mathrm{X}$. Tran et al. 2020). While serving this role in helping to tackle COVID-19, the majority of elderly patients in rural areas also need to continue to use these local centres for their personal health care (Nguyen and Giang 2021, 24). The district-level system in place in rural areas has been vulnerable during the pandemic (B. X. Tran et al. 2020). It is therefore necessary to formulate an effective plan for the distribution of financial support and human resources to strengthen the grassroots health system in the long run. It is also necessary to make sure that health centres at the local level can continue to provide elderly people with health care, even during global outbreaks of infectious diseases.

\section{Conclusion}

Vietnam quickly recognized the devastating nature of the COVID-19 pandemic and prepared for the outbreak before it had recorded its first case, well before the WHO issued its first warning. The WHO's recommendations therefore played no role in Vietnam's response to the COVID-19 pandemic in the initial stages. Vietnam's strategies can be considered an effective model for containing infectious diseases in settings where resources are limited. However, at the time of writing the pandemic remains far from over, and Vietnam's most vulnerable groups had been struggling. The COVID-19 pandemic highlights the need to care for economically disadvantaged groups, such as the elderly, in order to prevent long-term adverse health outcomes. To conclude, there is an urgent need in Vietnam for a social and health protection package, combined with improved access to essential services, particularly for vulnerable groups. 


\section{References}

Age International. 2020. 'Fighting Loneliness and COVID-19 in Vietnam.' 23 September. Accessed 12 April 2021. https://www.ageinternational.org.uk/news-features/ features/fighting-loneliness-and-covid-19-in-vietnam/.

BBC. 2020. 'Vietnam Health Ministry Calls Urgent Meeting.' 17 January. Accessed 12 April 2021. https://www.bbc.com/vietnamese/vietnam-51145923.

Bohane, Hugh. 2020. 'An Inside Look at Da Nang, Vietnam's Covid-19 Epicenter.' Saigoneer, 21 August. Accessed 12 April 2021. https://saigoneer.com/ vietnam-news/19125-an-inside-look-at-da-nang,-vietnam's-covid-19-epicenter.

Boin, Arjen, Martin Lodge, and Marte Luesink. 2020. 'Learning from the COVID-19 Crisis: An Initial Analysis of National Responses.' Policy Design and Practice vol. 3, no. 3: 189-204. https://doi.org/10.1080/25741292.2020.1823670.

Centres for Disease Control and Prevention (CDC). 2020. 'Contact Tracing Help Slow the Spread of Covid-19.' 25 February. Accessed 12 April 2021. https://vietnamese. cdc.gov/coronavirus/2019-ncov/daily-life-coping/contact-tracing.html.

Dam, Vu Duc. 2020. 'Số: 8o/QĐ-BCĐQG [Decision 80].' 7 February. Accessed 12 April 2021. https://thuvienphapluat.vn/van-ban/The-thao-Y-te/Quyet-dinh80-QD-BCDQG-2020-thanh-lap-Tieu-ban-chong-dich-benh-viem-duong-hohap-cap-Corona-4346oo.aspx.

DaNang Today. 2020. 'COVID-19 Updates on 25 June.' 25 June. Accessed 12 April 2021. https:/www.baodanang.vn/english/infographics/202006/ covid-19-updates-on-25-june-346389o/.

Garda World. 2020. 'Vietnam: Two Cases of 2019-NCoV Confirmed January 23.' 23 January. Accessed 12 April 2021. https:/www.garda.com/crisis24/ news-alerts/307976/vietnam-two-cases-of-2019-ncov-confirmed-january-23.

General Statistics Office. 2020a. 'Socio-Economic Situation in the Second Quarter and the First 6 Beginning Months of 2020.' 29July. Accessed 12 April 2021. https:// www.gso.gov.vn/en/data-and-statistics/2020/07/socio-economic-situation-inthe-second-quarter-and-the-first-6-beginning-months-of-2020/.

-.202ob. 'Workshop on Assessing Impacts of COVID-19 Outbreak on Vietnamese Corporate Sector.' 21 July. Accessed 12 April 2021. https://www.gso.gov.vn/en/ events/2020/o8/workshop-on-assessing-impacts-of-covid-19-outbreak-onvietnamese-corporate-sector-2/.

Gharib, Malaka. 2020. 'Older People, Got A Pandemic Problem? A Club To Help You Figure It Out - Yourself.' NPR, 23 September. Accessed 12 April 2021. https://www.npr.org/sections/goatsandsoda/202o/og/23/904604257/ older-people-got-a-pandemic-problem-a-club-to-help-you-figure-it-out-yourself. Ha, Bui Thi Thu, La Ngoc Quang, Tolib Mirzoev, Nguyen Trong Tai, Pham Quang Thai, and Phung Cong Dinh. 2020. 'Combating the COVID-19 Epidemic: Experiences 
from Vietnam.' International Journal of Environmental Research and Public Health vol. 17, no. 9. https://doi.org/10.339o/ijerph17093125.

Ha, Son Thai. 2020. 'Chốngdịchnhưchốnggiặc [Fighting against the Pandemic like Fighting against an Enemy].' 2 April. Accessed 12 April 2021. https://dangcongsan. vn/tieu-diem/chong-dich-nhu-chong-giac-551842.html.

Han, Emeline, Melisa Mei Jin Tan, Eva Turk, Devi Sridhar, Gabriel M Leung, Kenji Shibuya, Nima Asgari. 2020. 'Lessons Learnt from Easing COVID-19 Restrictions: An Analysis of Countries and Regions in Asia Pacific and Europe.' The Lancet vol. 396, no. 10261: 1525-34. https://doi.org/10.1016/So140-6736(20)32007-9.

HelpAge International. 2020a. 'Neglect and Abuse of Older People around the World Intensified by COVID-19.' 15June. Accessed 12 April 2021. https://reliefweb.int/report/ world/neglect-and-abuse-older-people-around-world-intensified-covid-19.

—. 202ob. 'The Impact of COVID-19 on Older Persons.' June. https://ageingasia.org/ wp-content/uploads/2020/o8/4.-Vietnam-Analytical-Brief-June-2020_A.pdf.

International Labour Organization (ILO). 2020. 'Current Situation: Why Are Labour Markets Important?' ILO Monitor ${ }^{\text {st }}$ Edition, 18 March. Accessed 12 April 2021. https://www.ilo.org/wcmsp5/groups/public/---dgreports/---dcomm/documents/ briefingnote/wcms_738753.pdf.

Kiet, Anh. 2020. 'Nearly $89 \%$ of Vietnam Population Covered by Health Insurance.' Hanoi Times, 24 June. Accessed 12 April 2021. http://hanoitimes.vn/nearly-89-ofvietnam-population-covered-by-health-insurance-312803.html.

Le, Xuan Thi Thanh, Anh Kim Dang, Jayson Toweh, Quang Nhat Nguyen, Huong Thi Le, Toan Thi Thanh Do, Hanh Bich Thi Phan. 2020. 'Evaluating the Psychological Impacts Related to COVID-19 of Vietnamese People Under the First Nationwide Partial Lockdown in Vietnam.' Frontiers in Psychiatry vol. 11 (September). https:// doi.org/10.3389/fpsyt.2020.00824.

Ministry of Health (MOH). 2020a. 'Chínhphủmởộngđốitượngđượchỗtrợ do ảnhhưởngcủa COVID-19 [COVID-19 Policy Response Notes for Vietnam].' 20 October. Accessed 12 April 2021. https://ncov.moh.gov.vn/en/web/guest/-/6847912-28.

—. $202 \mathrm{ob}$. 'Huyđộngtoànbộlựclượng y tếphòng, chốngđạidịch COVID-19 [Mobilize the Entire Medical Force for the Prevention and Control of the Epidemic COVID-19].' 21 March. Accessed 12 April 2021. https:// moh.gov.vn/tin-tong-hop/-/asset_publisher/k2o6Q9qkZOqn/content/ huy-ong-toan-bo-luc-luong-y-te-phong-chong-ai-dich-covid-19.

—.2020c. 'Kit test xétnghiệm COVID-19 củaViệt Nam cónhữngưuđiểmvượttrội [Vietnam Creates Advanced Test Kit].' 6 March. https://ncov.moh.gov.vn/web/ guest/-/kit-test-xet-nghiem-covid-19-cua-viet-nam-co-nhung-uu-iem-vuot-troi. —. 2020d. 'Quyếtđịnh 125/QĐ-BYT ngày 16/01/2020 vềviệcHướngdẫnChẩnđoán vàđiềutrịbệnhviêmphổicấp do chủngvirut Corona mới (nCoV) [Decision 125, 16th January 2020 on Guidelines for the Diagnosis and Treatment of Acute 
Pneumonia Caused by COVID-19].' 16 January. Accessed 12 April 2021. http:// vaac.gov.vn/vanban_detail/Detail/Quyet-dinh-125-QD-BYT-ngay-16-01-2020ve-viec-Huong-dan-Chan-doan-va-dieu-tri-benh-viem-phoi-cap-do-chungvirut-Corona-moi-nCoV-

—. 2020e. 'Quyếtđịnh về việc thành lập đội cơ động phản ứng nhanh chống dịch viêm đường hô hấp cấp do chủng mới CORONA (nCoV) [Decision No. $255 /$ QD-BYT on the establishment of a Rapid Response Team to control the novel coronavirus disease (NCOV)].' 30 January. Accessed 13 April 2021. https://thuvienphapluat.vn/van-ban/The-thao-Y-te/Quyet-dinh-225-QD-BYT-2020-thanhlap-doi-co-dong-chong-dich-viem-duong-ho-hap-cap-Corona-433439-aspx.

—. 2020f. 'Quyếtđịnh 1588/QĐ-BYTvề việc hướng dẫn quản lý sức khỏe người cao tuổi trong bối cảnh dịch covid') [Decision 1588/QD-BYT on Guidelines for temporary management of the health of the elderly and people with chronic diseases at the grassroots level in the context of the COVID-19 pandemic].' 30 January. Accessed 13 April 2021. https://thuvienphapluat.vn/van-ban/The-thao-Y-te/ Quyet-dinh-1588-QD-BYT-2020-tai-lieu-chuyen-mon-Huong-dan-quan-ly-suckhoe-nguoi-cao-tuoi-439236.aspx.

—. 2020i. 'Quyếtđịnh 1588/QĐ-BYTvề việc Về việc ban hành tài liệu chuyên môn "Hướng dẫn chăm sóc sức khỏetâm thần trong dịch COVID-19 [Decision 1588/QD-BYT on Guidelines for the mental health care in the context of the COVID-19 pandemic.].' 14 May. Accessed 13 April 2021. https://luatvietnam. vn/y-te/quyet-dinh-2057-qd-byt-huong-dan-cham-soc-suc-khoe-tam-thantrong-dich-covid-19-183472-d1.html.

Ministry of Transport. 2020. 'Chỉthịvềviệcphòng, chốngdịchbệnhviêmđườnghôhấpcấp do chủngmớicủa vi rút Corona gâyra [Directive on Prevention and Control of Acute Respiratory Infections Caused by a New Strain of Corona Virus].' 29 January. Accessed 12 April 2021. https://caa.gov.vn/van-ban/362-ct-chk-13221.htm.

Nguyen, Anh Tuyet, and Thanh Long Giang. 2020. 'Factors Associated with Regional Disparity in Utilization of Healthcare Services among the Vietnamese Older People.' Journal of Population Studies (JPSS) vol. 29: 15-31. https://soo3.tci-thaijo. org/index.php/jpss/article/view/240847.

Nguyen, Kylie. 2020. 'COVID-19 Pandemic: Proposal of VND 62,00o Billion Support Package, Targeting 20 Million People.' Agribank, 7 April. Accessed 12 April 2021. https://www.agribank.com.vn/en/ve-agribank/tin-tuc/dtl?cu rrent=true\&urile=wcm:path:/agbanken/ve-agribank/news/market-news / proposal-of-support-package-targeting-20-million-people.

Nhan Dan News. 2020. 'Vietnam Records No Suspicion of Mysterious Pneumonia from China: Health Ministry.' 1 September. Accessed 12 April 2021. https:// en.nhandan.org.vn/society/health/item/8308002-vietnam-records-no-suspicionof-mysterious-pneumonia-from-china-health-ministry.html. 
Ohya, Kazuhide. 2020. 'Vietnam Regulatory Update in Response to COVID-19.' Lexology, 24 September. Accessed 12 April 2021. https://www.lexology.com/ library/detail.aspx?g=114e140a-881e-477b-ba58-fbffdd 46738 b.

Phuc, Nguyen Xuan. 2020a. 'Chỉthịsố 05/CT-TTg 2020 của Thủtướng Chínhphủvềphòng, chống virus Corona [Directive No. 05 / CT-TTg 2020 of the Prime Minister on Corona Virus Prevention and Control].' 30 January. Accessed 12 April 2021. http://www.medinet.hochiminhcity.gov.vn/giam-doc-cac-benh-vien-canbiet/chi-thi-so-05ct-ttg-2020-cua-thu-tuong-chinh-phu-ve-phong-chong-viruscorona-cmobile13465-23380.aspx.

—. 202ob. 'Quyết định số 170/QĐ-TTg của Thủ tướng Chính phủ : Về việc thành lập Ban Chỉ đạo Quốc gia phòng, chống dịch bệnh viêm đường hô hấp cấp do chủng mới của vi rút Corona gây ra [Decision No. 170/ QD-TTg on Establishing the National Steering Committee for Prevention and Control of Acute Respiratory Infections Caused by New Strains of Corona Virus]. http://vanban.chinhphu.vn/portal/page/portal/chinhphu/ hethongvanban?class_id=2\&_page=1\&mode=detail\&document_id=198963.

—. 2020c. 'HướngdẫnthựchiệnChỉthị 16/CT-TTgvềcáchlyxãhội [Guidance on the Implementation of Directive 16 / CT-TTg on Social Isolation].' 4 April. Accessed 12 April 2021. https://moh.gov.vn/hoat-dong-cua-lanh-dao-bo/-/asset_publisher/ TW6LTp1ZtwaN/content/huong-dan-thuc-hien-chi-thi-16-ct-ttg-ve-cach-lyxa-hoi.

Takashima, Kyoko, Koji Wada, Ton Thanh Tra, and Derek R. Smith. 2017. 'A Review of Vietnam's Healthcare Reform through the Direction of Healthcare Activities (DOHA).' Environmental Health and Preventive Medicine vol. 22, no. 1 (74). https:// doi.org/10.1186/s12199-017-0682-z.

ThưViệnPhápLuật. 2020a. 'Vềviệc ban hành "hướngdẫncáchly y tếtạinhà, nơilưutrúphòngchốngdịchCOVID-19 [Guidance on How Medical Diversion at Home and Places to Residence COVID-19].' 12 March. Accessed 12 April 2021. https:/thuvienphapluat.vn/van-ban/The-thao-Y-te/Quyet-dinh-879-QDBYT-2020-Huong-dan-cach-ly-y-te-tai-nha-noi-luu-tru-phong-chong-dichCOVID-19-437036.aspx.

—. 2020b. 'Nguyênnhântửvongcủacácbệnhnhânmắc COVID-19 tại Việt Nam [The Cause of Death of COVID-19 Patients in Vietnam].' 3 September. Accessed 12 April 2021. https://huvienphapluat.vn/tintuc/vn/thoi-su-phap-luat/thoisu/30265/tong-hop-nguyen-nhan-tu-vong-cua-cac-benh-nhan-mac-covid-19.

Tran, Bach Xuan, Men Thi Hoang, Hai Quang Pham, Chi Linh Hoang, Huong Thi Le, Carl A Latkin, Cyrus SH Ho, and Roger CM Ho. 2020. 'The Operational Readiness Capacities of the Grassroots Health System in Responses to Epidemics: Implications for COVID-19 Control in Vietnam.'Journal of Global Health vol. 10, no. 1. https://doi.org/10.7189/jogh.10.011006. 
Tran, Phuong Bich, Gunnel Hensing, Tom Wingfield, Salla Atkins, Kristi Sidney Annerstedt, Joseph Kazibwe, Ewan Tomeny, Olivia Biermann, Jennifer Thorpe, Rachel Forse, and Knut Lönnroth. 2020. 'Income Security during Public Health Emergencies: The COVID-19 Poverty Trap in Vietnam.' BMJ Global Health vol. 5, no. 6: 3-6. https://doi.org/10.1136/bmjgh-2020-002504.

Trevisan, Maurizio, Linh Cu Le, and Anh Vu Le. 2020. 'The COVID-19 Pandemic: A View from Vietnam.' American Journal of Public Health vol. 110, no 8: 1152-1153. https://doi.org/10.2105/AJPH.2020.305751.

UNICEF. 2020. 'Viet Nam Country Office.' Situation Report, 8 April. Accessed 12 April 2021. https://reliefweb.int/report/viet-nam/unicef-viet-nam-countryoffice-covid-19-situation-report-no-1-reporting-period-1.

United Nations (UN). 2020. 'Economic Response Plan United Nations in Vietnam.' United Nations in Viet Nam. Accessed 12 April 2021. https://unsdg.un.org/sites/ default/files/2020-10/VNM_Socioeconomic-Response-Plan_2020.pdf.

USAID. 2020. 'Threats, Pandemic Influenza and Other Emerging Threats.' Accessed 12 April 2021. https://www.usaid.gov/vietnam/pandemic-influenza-and-otheremerging-threats.

Vietnam News. 2020. ‘Gov’t Considering Unprecedented US\$2.6b Support Package for Vietnamese Hit by COVID-19.' Viet Nam News Politics \& Law. Last updated 2 April 2020. Accessed 24 February 2021. https://vietnamnews.vn/politicslaws/674554/govt-considering-unprecedented-us26b-support-package-forvietnamese-hit-by-covid-19.html.

Vietnam Women Union. 2012. Vietnam Aging Survey (VNAS) 2011: Key Findings. Hanoi: Women Publishing House.

World Health Organization (WHO). 2020. '2019 Novel Coronavirus (2019-nCoV): Strategic Preparedness and Response Plan.' February. Accessed 12 April 2021. https://www.who.int/docs/default-source/searo/whe/coronavirussig/covid19-sprp-whe-searo-feb-2020.pdf?sfvrsn=9ee4976o_2.

—. 2020a. 'Announced, Independent Evaluation of Global COVID-19 Response.' 9 July. Accessed 12 April 2021. https://www.who.int/news-room/detail/og07-2020-independent-evaluation-of-global-covid-19-response-announced.

- 2020b. 'Guidance on COVID-19 for the Care of Older People and People Living in Long-Term Care Facilities, Other Non-Acute Care Facilities and Home Care.' 5 October. Accessed 12 April 2021. https://www.who.int/publications/i/item/ WPR-DSE-2020-015.

—. 2020c. 'Listing of WHO's Response to COVID-19.' 29 June. Accessed 12 April 2021. https://www.who.int/news/item/29-06-2020-covidtimeline.

- $2020 d$. 'Statement on the Second Meeting of the International Health Regulations (2005) Emergency Committee Regarding the Outbreak of Novel Coronavirus (2019-NCoV).' 30 January. Accessed 12 April 2021. https://www.who. 
$\mathrm{int} /$ news-room/detail/30-01-2020-statement-on-the-second-meeting-of-theinternational-health-regulations-(2005)-emergency-committee-regarding-theoutbreak-of-novel-coronavirus-(2019-ncov).

- 2020e. 'Statement on the Second Meeting of the International Health Regulations (2005) Emergency Committee Regarding the Outbreak of Novel Coronavirus (2019-NCoV).' 30 January. Accessed 12 April 2021. https://www.who.int/news/ item/30-01-2020-statement-on-the-second-meeting-of-the-international-healthregulations-(2005)-emergency-committee-regarding-the-outbreak-of-novelcoronavirus-(2019-ncov).

-. 202 of. 'Novel Coronavirus (NCoV) V1.' COVID-19 Case Management, 6 March. Accessed 12 April 2021. https://www.who.int/publications/i/item/ disease-commodity-package---novel-coronavirus-(ncov).

- 2020 g. 'Timeline of WHO's Response to COVID-19.' 29 June. Accessed 12 April 2021. https://www.who.int/news-room/detail/29-06-2020-covidtimeline.

Worldometer. 2020a. 'Reported Cases by Country, Territory, or Conveyance.' Accessed 12 April 2021. https://www.worldometers.info/world-population/ population-by-country/.

—. 2020b. 'COVID-19 Coronavirus Pandemic.' Accessed 12 April 2021. https://www. worldometers.info/coronavirus/?utm_campaign=homeAdvegası?\#countries.

\section{About the Author}

Anh Tuyet NGUYEN is a PhD student at the Osaka School of International Public Policy (OSIPP), Osaka University. Her current research interests are public health, inequality, aging population, Asian studies, and applied econometrics. Her most recent publications include 'Socio-economic-related Health Inequality in Non-communicable Diseases Among Older People in Viet Nam,' D.D. Le, R. Leon-Gonzalez, T.L. Giang, and A.T. Nguyen (2020), Ageing \& Society, and 'Factors Associated with Regional Disparity in Utilization of Healthcare Services Among Vietnamese Older People,' A.T. Nguyen and T. Giang (2020), Journal of Population and Social Studies. Previously, she worked as a senior credit assessment officer in the Risk Management Department at a local bank in Vietnam for eight years. This position, at a dynamic financial institution, gave her valuable practical experience about large corporate issues, as well as a deep understanding of the domestic economic industry in Vietnam and other developing countries. 


\title{
9 The Coordination of COVID-19 Responses in Malaysia
}

\author{
Efforts and Challenges
}

Nurliana KAMARUDDIN and Zokhri IDRIS

\begin{abstract}
Historically, Malaysia has demonstrated good, coordinated strategies in dealing with disease outbreaks. However, COVID-19 has been larger in scale than previous pandemics and the country was in the midst of political upheaval when the first case was detected in the country. This chapter examines the coordination between political actors and analyses the challenges Malaysia faced as a result of the outbreak, specifically regarding the treatment of migrant workers and strict border controls. It highlights the country's need for consistent policies for workers and shows that Malaysia needs to balance health security, political stability, and economic growth in order to successfully manage the pandemic.
\end{abstract}

Keywords: Malaysia, health security, political stability, public health, COVID-19

\section{Introduction}

When the first COVID-19 case was detected in Malaysia on 4 February 2020, the country was in the middle of political unrest. The historic change of Malaysia's ruling coalition that occurred in the 2018 general election, from Barisan Nasional (BN) to Pakatan Harapan (PH), had lasted for a mere two years. Then $\mathrm{PH}$ fell apart due to infighting and changing party allegiances. Following the withdrawal of BERSATU (one of the parties that made up the ruling coalition) from $\mathrm{PH}$ on 23 February 2020, PH no longer held a majority

\footnotetext{
Van der Veere, Anoma P., Florian Schneider, and Catherine Yuk-ping Lo (eds), Public Health in Asia during the COVID-19 Pandemic: Global Health Governance, Migrant Labour, and International Health Crises. Amsterdam, Amsterdam University Press 2022 DOI: 10.5117/9789463720977_CHo9
} 
of parliamentary seats. This led to the resignation of the then Prime Minister Mahathir Mohamad.

Between 24 and 28 February, Malaysia did not have a Prime Minister or cabinet members. Muhyiddin Yassin, then Minister of Home Affairs, was appointed Prime Minister by the King on 1 March 2020. Other cabinet members were sworn in on 7 March, after there had been no cabinet members in office for fourteen days. As a result, Malaysia witnessed a lack of coordination in infectious disease control, leading to a spike where there were 25 cases of COVID-19 in February (Ministry of Health Malaysia 2020a). Despite the country losing ground during the initial stage of the outbreak, the newly formed government was quick to implement measures, prioritizing testing, tracing, and containment.

This chapter will examine the Malaysian government's actions in tackling the COVID-19 crisis. It will first examine the coordination between political actors and civil servants, including health and security practitioners, as well as the economic support provided by the government. It will then examine the challenges Malaysia has faced as a result of the outbreak as well as the policies implemented to contain the virus. Finally, it will conclude by discussing how Malaysia might move forward in these uncertain times.

\section{Coordinating Public Services during the Pandemic}

Malaysia's first COVID-19 cases were detected when three out of eight Chinese nationals entering the southern state of Johor Bahru tested positive on 25January 2020. The first major cluster of local cases came from a religious gathering that was held in the suburb of Sri Petaling (Kanyakumari 2020). Since the Islamic gathering had over 16,00o attendees, the government took urgent measures when the first case from this cluster was found on 11 March. To contain the outbreak, the Malaysian government needed to efficiently coordinate across various ministries and agencies.

Before COVID-19, Malaysia had experienced several other infectious disease outbreaks and the authorities had demonstrated an effective capacity to deal with the past smaller-scale outbreaks. In 1996, a major cholera outbreak hit the northern state of Penang. The authorities reported a total of 1182 cases and detected 231 carriers, but the outbreak resulted in zero deaths. In 1997, the Malaysian state of Sarawak reported an outbreak of Hand, Foot and Mouth Disease (HFMD). This resulted in 31 deaths, a total that was relatively low in proportion to the number of deaths worldwide. Two years later, Malaysia also saw an outbreak of Nipah Encephalitis that 
resulted in 283 recorded cases and 109 deaths. In 2001, Malaysia experienced an Anthrax scare attributed to a bioterrorist attack. There were 136 reported cases with no fatalities. Considering these events, the Malaysian government and its Ministry of Health had a proven track record in handling infectious diseases prior to the COVID-19 pandemic. The government had demonstrated excellent coordination in containing diseases and preventing them from reaching larger groups of Malaysian residents.

COVID-19 nevertheless has presented a different dynamic. The Minister of Health, under the Prevention and Control of Infectious Diseases Act (PCID) 1988, declared that COVID-19 was a national outbreak. Under the PCID, when a disease is classified in this way it requires the active intervention of the authorities. That said, COVID-19's characteristics show no similarity to previous infectious diseases. The former has a fast-spiralling effect where individuals can be infected either through air-borne water droplets or through physical contact with people or objects contaminated with the virus. The rapid escalation of infection led to the Malaysian government declaring COVID-19 a national disaster. ${ }^{1}$ This declaration took into account the exponential growth of infection globally. The labelling of COVID-19 as a national disaster for Malaysia meant that proactive government intervention was required to stop the spread of the outbreak. Since 1969, the country has not undergone any other catastrophe that has required government intervention at the national level.

The Malaysian National Security Council (NSC) activated an emergency structure to combat COVID-19. On 18 March 2020, Malaysia imposed a nationwide Movement Control Order (MCO). The measure was intended to limit citizens' movements in order to break the chain of infections. Businesses were required to close except for essential services, and the general public were only allowed limited travel. Interstate travel was prohibited and any areas with more than 40 cases were considered red zone areas and were cordoned (Tang 2020). Malaysia also enforced strict quarantine measures for those travelling into the country and prohibited any form of mass gatherings. These measures were all strictly enforced, first by the police and later with the assistance of the military (Loh 2020).

The NSC, which is chaired by the Prime Minister, has convened frequently to receive reports, analyse possible actions, and prepare a standard operating procedure for all citizens and other Malaysian residents. This standard

1 Under Directive No.20 of National Security Council (MKN 20), a disaster is defined as 'an incident that occurs without warning, complex in nature and results in loss of lives, property and damage to the environment.' 
Table 9.1 Daily reported cases from 25 September to 12 October 2020

\begin{tabular}{lcc}
\hline Date (2020) & New cases & Total active cases \\
\hline 25 September & 111 & 858 \\
26 September & 82 & 851 \\
27 September & 150 & 950 \\
28 September & 115 & 1,011 \\
29 September & 101 & 1,062 \\
30 September & 89 & 1,121 \\
1 October & 260 & 1,334 \\
2 October & 287 & 1,540 \\
3 October & 317 & 1,735 \\
4 October & 293 & 1,961 \\
5 October & 432 & 2,336 \\
6 October & 691 & 2,936 \\
7 October & 489 & 3351 \\
8 October & 375 & 3351 \\
9 October & 354 & 3863 \\
10 October & 374 & 4161 \\
11 October & 561 & 4587 \\
12 October & 563 & 5039 \\
\hline
\end{tabular}

Source: Ministry of Health, Malaysia 2020c.

operating procedure has then been communicated to the public by the Senior Minister of Defence through a televised briefing at 14:00 hrs each day (during the first period of the Movement Control Order [MCO]). The Ministry of Health, through its director-general, has also televised reports about the number of new cases, existing cases, and deaths at 17:0o hrs each day. According to the modelling and forecasting conducted by the National Institute of Health, the MCO effectively controlled the transmission of COVID-19 (Ministry of Health 2020b). The transmission rate decreased from the alarming three-digit figures seen in the early months to single-digit figures in the months after that until the end of September. The success of the MCO and the subsequent decline of infection rates allowed the government to slowly ease the MCO. On 4 May 2020 it implemented the Conditional Movement Control Order (CMCO) and then on 10 June it implemented the Recovery Movement Control Order (RMCO). These two orders saw the gradual loosening of prohibited activities. Businesses could operate as long as they followed the standard operating procedures (SOP). ${ }^{2}$

2 Some examples of these SOPs include businesses having only $30 \%$ of their essential operation teams on the premises. Non-essential staff members were instructed to work from home. Stores 
Despite this success story, Malaysia began to experience another spike of COVID-19 cases in late September 2020. On 25 September, the authorities reported a total of 111 cases. In the subsequent months, the country's daily reported cases consistently increased (see Table 9.1). The increase sparked fears of a third wave. Currently, with stringent contact tracing and targeted lockdown orders in place, the Malaysian government has expressed confidence that the situation is under control (Loheswar 2020).

Aside from controlling and monitoring the number of cases, the Malaysian government has also provided economic assistance for the affected populations as part of its COVID-19 measures. The government distributed Pakej Prihatin (loosely translated as 'Care Packages') in different stages to aid those Malaysians who had been economically affected by the outbreak. The first package was released on 26 February, which gave financial allowance to public healthcare workers, and also financial aid to households in the middle and bottom 40\% (known as $\mathrm{B}_{40}$ and $\mathrm{M}_{40}$ households). Households and individual earners were awarded RM10oo to RM16oo (approximately USD $\$ 250$ to USD \$400) and RM250 to RM500 (approximately USD \$6o to USD\$125) respectively, according to their projected income (Prime Minister's Office 2020a).

Subsequently, the government released an additional Prihatin package on 6 April. These funds were intended to help small and medium enterprises (SMEs) to retain employees and avoid business closures. Following a series of consultations with financial institutions, the authorities announced special packages to aid retrenched employees and locally-based SMEs. On $29 \mathrm{July}$, the government extended a previous loan moratorium for retrenched citizens by a further three months. Employed citizens who have received pay cuts as a result of COVID-19 have also been able to negotiate with their banks on payment adjustments. Meanwhile, SMEs have been allowed to pay interest to their banks at a later time, to extend their loan periods, as well as to receive other payment exemptions that are reasonable to both parties (Prime Minister's Office 202ob).

\section{Issues and Challenges}

Handling a global pandemic can prove challenging even for the most advanced nations. The COVID-19 pandemic shows that economic strength does 
not equate to effective governance in dealing with the outbreak. Malaysia has faced its share of challenges in its effort to combat the pandemic: the government has to deal with domestic issues, such as a lack of compliance by some sectors as well as inconsistencies in policy announcement and enforcement. In Malaysia, one of the biggest challenges that the pandemic has caused is linked to the issue of controlling the movement and migration of people. This section will explore two major challenges that Malaysia faces. The first is the way that cases involving foreigners have been linked to the larger issue of illegal migration, raising questions about how migrants are treated in Malaysia. The second concerns the implications stemming from the extended entry restrictions that Malaysia enacted.

On 18 September 2020, Malaysia recorded 21 new cases, of which only one case involved a non-Malaysian. This positive turn of events however was preceded by a tumultuous period where a large number of cases had been found amongst groups of low-skilled migrant workers. Between April and May 2020, clusters of infection were traced back to migrant workers ranging from security guards to construction workers (Code Blue 2020). For example, the Ministry of Health disclosed on 25 April 2020 that from 14,187 foreign workers who were tested, 676 had tested positive for COVID-19. This was followed with the disclosure on 1 June 2020 that 2014 individuals out of 35,811 non-citizens tested were found to be COVID-19 positive (Tan, Mohd Noor, and Khalidi 2020).

The organization Business and Human Rights Resource Centre (2020) warned about the relatively high exposure of migrant workers to COVID-19, in particular among those working in unhygienic environments, such as those categorized as working in ' $3 \mathrm{D}$ ' employment, meaning that which is dangerous, dirty, and difficult (Sukumaran 2020). The low standards of living in the communities of migrant workers could also be problematic in relation to their exposure to COVID-19. Residences are usually crowded in construction areas, which cram workers into small units. Poor sanitation and inadequate sewage systems impact the living condition of foreign workers and thus increase their likelihood of infection.

To contain the spread of the virus, the Malaysian government has increased immigration raids, made testing mandatory for migrant workers, and prohibited the hiring of new foreign workers (Babulal 2020). The news organization Al Jazeera produced a documentary about the Malaysian government's treatment of migrants during the pandemic, criticizing what it saw as draconian measures which included inhuman conditions of detention and deportation (Al Jazeera 2020). In response, the Malaysian authorities deported a Bangladeshi worker interviewed in the documentary 
and investigated the news agency for defamation and sedition (Rodzi 2020). There has been a mixed reaction to the documentary and the government's response. Some news media have accused the Malaysian government of being authoritarian and anti-freedom-of-speech (Peter 2020; Smith 2020). Others have given the government their support. They state that the news channel purposely misrepresented the government. They argued that claims that the government's actions were racist misconstrued these actions and that the government's measures have been based on containing the virus and not on any racial discrimination (Yunus 2020; Malay Mail 2020).

Malaysia has covered the costs of COVID-19 testing for all the workers whose employers contribute to the national social security organization (New Straits Times 2020). The Malaysian government has also continued to provide medical care for all migrant workers infected with the virus, regardless of their immigration status. The government likewise prepared a 6oo-bed quarantine facility specifically for migrant workers (Landau 2020). It declared that those workers who were found to be in the country illegally would be deported after treatment (Kaos and Sivanandam 2020). There have also been repeated calls from the Ministry of Health's directorgeneral to ensure that there is no discrimination in the treatment provision (Hermesauto 2020).

Alongside the testing subsidies, financial aid from the government arguably has not reached the bulk of foreign workers as the aid has mostly been channelled to SMEs owned by Malaysians and employing Malaysian citizens. The employment of migrant workers in Malaysia is largely concentrated in large-scale construction firms and restaurants, with a group of migrant workers also employed in individual households as domestic helpers. Migrant workers who were employed on construction sites and in restaurants were seriously affected by the MCO because of temporary closures. Most of the companies in these two industries are not SMEs but larger corporations which have not been fully covered by the Prihatin economic assistance. In all cases, the Malaysian government's financial packages have not reached migrant workers directly. As such, migrant workers' livelihoods have largely depended on the performance of their employers in weathering the pandemic.

Leaving aside the debate about whether Malaysia has been unfair in its treatment of illegal migrant workers, the pandemic has revealed major problems with the status quo in Malaysia. Malaysia's dependency on foreign workers for low skilled jobs means that the government has been inconsistent in handling the issue of undocumented workers in the country. Besides, Malaysia has no separate official policy on refugees and asylum seekers, 
leading to a sizable number of unregistered migrants in the country. The conditions of immigration detention centres for arrested illegal migrants are poor, with migrants kept in close and cramped quarters (Global Detention Project 2020).

The COVID-19 pandemic has highlighted the fact that Malaysia needs a major overhaul of its labour and migration laws in order to lessen its dependency on cheap foreign labour and provide better protection for both local and foreign workers in case another pandemic occurs. The International Labour Organization has provided suggestions concerning migrant workers (Sandanasamy, Paavilainen, and Baruah 2020). This includes the observation that one of the best ways to get undocumented migrants to voluntarily come for testing and treatment during the outbreak is to ensure that there is no fear of detainment and that costs are subsidised or borne by the government. At the same time, the enforcement of labour laws still needs to be upheld.

Malaysia's decision to enact stricter border controls as a means to control the pandemic has had economic and political implications for the country. One economic implication is the impact on tourism. Tourism, which is a big contributor to the Malaysian economy, has been one of the industries hardest hit by the pandemic. At the time of writing (September 2020), Malaysia had extended the travel ban on foreign tourists until the end of December 2020. On 7 September, it also introduced an entry prohibition for countries with over 150,000 cases. The list includes 23 countries, such as the United States, Brazil, and India. The travel ban grants exemption only to diplomatic travellers, while barring students and workers and spouses with long term visas from entering the country for an indefinite period.

The decision has not been a popular one. The government has received appeals from various sectors and especially from members of the business community such as the American Malaysian Chamber of Commerce (Bernama 2020; The Star 2020). It has also received appeals from local investment promotion agencies (Lim 2020). These agencies point out that the entry restrictions not only impact immediate economic growth and employment but could likewise have more far-reaching consequences, such as a loss of trust in the reliability of Malaysia as a trade partner and place of business. Malaysia's government needs to consider the loss of overseas expertise that companies based in Malaysia depend on.

Similarly, the travel ban may impact other sectors. Restricting international students coming into the country may also affect universities and the attractiveness of Malaysia as a hub for higher education. In addition, Malaysia is known as a medical tourism destination, and thus the travel ban could have consequences in this industry. There are fears that the 
pandemic might mean that Malaysia would enforce tighter border controls. As a country that is dependent on foreign workers, this could lead to an increase in illegal migration instead. Such a phenomenon would potentially compound some of the problems that Malaysia is already facing and that have been discussed earlier in this chapter

Overall, there are many sacrifices and trade-offs that the government has made to enhance public health and safety. Malaysia should learn from its current experience in order to handle future crises in a more consistent manner. What remains to be seen are the long-term consequences of the measures that have been taken during the pandemic. It is not yet known whether the economic impacts of the MCO will be manageable. Although the Malaysian government has continued to provide economic stimulus and financial assistance packages, these solutions are not sustainable. The government will thus need to consider what it can do to help sustain economic growth, not only by maximizing its comparative advantage, but also by ensuring that it remains actively engaged with international markets and sustains international supply chains.

\section{Conclusion}

Malaysia provides an interesting case study of how a professional and wellestablished civil service can hold a country together during the COVID-19 outbreak, even in times of political crisis. Although ministerial posts were changing hands and newly appointed ministers were tasked with facing the national crisis, consultation and dependence on the civil service and experts provided Malaysia with the means to tackle the pandemic. It is still important to note that at the time of writing Malaysia remains under the restrictions of a RMCO. Several new clusters of infections have been detected and are being closely monitored by the government. The government has also imposed quarantine requirements for all travellers coming into Malaysia as well as those travelling between so-called 'red-zone' states.

The COVID-19 crisis shows that the issue of migrant workers in Malaysia remains a challenge. Although these workers have received healthcare from the public hospitals, they will still face legal punishment, which includes immediate deportation back to their home country. In terms of economic assistance, the well-being of migrant workers is mostly dependent on whether the company they work for has taken steps to ensure this. It is difficult to estimate the amount of government aid that reaches migrant workers. In the midst of this, Malaysia's political future also remains uncertain, since 
there is no clear-cut majority in parliament. It is likely that the political uncertainty will further impact and aggravate the damage that the pandemic has wrought on Malaysia's economy.

\section{References}

Al Jazeera. 2020. 'Locked Up in Malaysia's Lockdown.' Malaysia, AlJazeera, 3 July. Accessed 2 October 2020. https://www.aljazeera.com/programmes/101east/2020/07/ locked-malaysia-lockdown-200702104523280.html.

Babulal, Veena. 2020. 'Malaysia to Deport All Covid-19 Negative Undocumented Workers [NSTTV].' New Straits Times, 26 May. Accessed 25 September 2020. https://www.nst.com.my/news/nation/2020/05/595449/ malaysia-deport-all-covid-19-negative-undocumented-workers.

Bernama. 2020. 'Dewan Perniagaan Amerika minta kerajaan pertimbang semula larangan kemasukan warga AS ke Malaysia.' Astro Awani, 4 September. Accessed 5 October 2020. https://www.astroawani.com/berita-malaysia/ dewan-perniagaan-amerika-minta-kerajaan-pertimbang-semula-larangankemasukan-warga-as-ke-malaysia-258067.

Code Blue. 2020. 'Malaysia Tested 73,00o Foreigners for Coronavirus, 3.7\% Positive.' Galen Centre for Health and Social Policy, 14 August. Accessed 2 October 2020. https://codeblue.galencentre.org/2020/08/14/ malaysia-tested-7300o-foreigners-for-coronavirus-3-7-positive/.

Global Detention Project. 2020. 'Malaysia: Covid 19 Updates.' Global Detention Project, 16 April. Accessed 16 March 2021. https://www.globaldetentionproject. org/countries/asia-pacific/malaysia.

Hermesauto. 2020. 'Malaysia's Health Chief Warns against Discrimination of Migrant Workers amid Coronavirus Outbreak at Detention Centres.' The Straits Times, 25 May. Accessed 16 February 2021. https://www.straitstimes.com/asia/ se-asia/coronavirus-breaks-out-at-detention-centres-in-malaysia-healthministry-warns-against.

Jabatan Perdana Menteri. 2020a. 'Teks Ucapan Perutusan Khas Pakej Rangsangan Ekonomi Prihatin Rakyat (PRIHATIN).' Pejabat Perdana Menteri Malaysia, 27 March. Accessed 28 September 2020. https://www.pmo.gov.my/ms/2020/03/ teks-ucapan-perutusan-khas-pakej-rangsangan-ekonomi-prihatin-rakyatprihatin.

- 2020b. 'Teks Ucapan Pengumuman Lanjutan Moratorium Bantuan Bank Bersasar.' Prime Minister's Office of Malaysia, 29 July. Accessed 28 September 2020. https://www.pmo.gov.my/2020/07/teks-ucapan-pengumuman-lanjutanmoratorium-bantuan-bank-bersasar/. 
Kanyakumari. D. 2020. 'What We Learnt from the Three Biggest COVID-19 Clusters in Malaysia.' Channel News Asia, 28 July. Accessed 16 February 2021. https://www. channelnewsasia.com/news/asia/malaysia-covid-19-largest-clusters-tablightahfiz-foreign-worker-12961276.

Kaos Jr, Joseph, and Hemananthani Sivanandam. 2020. 'Govt Defends Treatment of Foreign Workers during Covid19, Including Undocumented Ones.' The Star Online, 27 May. Accessed 28 September 2020. https://www.thestar.com.my/ news/nation/2020/05/27/govt-defends-treatment-of-foreign-workers-duringcovid19-including-undocumented-ones.

Landau, Esther. 2020. 'Covid-19 Positive Migrants Quarantined at MAEPS, Reducing Risk of Spread at Depots.' NST Online (New Straits Times), 25 May. Accessed 4 October 2020. https:/www.nst.com.my/news/nation/2020/05/595259/ covid-19-positive-migrants-quarantined-maeps-reducing-risk-spread-depots.

Lim, Justin. 'Malaysia Told to Reconsider Entry Ban on Citizens of Countries with over 150,000 Covid-19 Cases.' The Edge Markets, 7 September. Accessed 28 September 2020. https://www.theedgemarkets.com/article/malaysia-toldreconsider-entry-ban-citizens-countries-over-1500oo-covid19-cases.

Loh, Foon Fong. 2020. 'Army to Assist Cops in Enforcing MCO from Sunday (March 22).' The Star Online, 20 March. Accessed 28 September 2020. https:// www.thestar.com.my/news/nation/2020/03/20/army-to-assist-cops-enforcemco-on-sunday-march-22.

Loheswar, Rathakrishnan. 2020. 'Dr Noor Hisham Says Klang Valley Covid-19 Spread under Control, CMCO and TEMCO way to go.' Malay Mail, 21 December. Accessed 17 March 2021. https://www.malaymail.com/news/malaysia/2020/12/21/ dr-noor-hisham-says-klang-valley-covid-19-spread-under-control-cmco-andtem/1933965.

Malay Mail. 2020. 'Covid-19: Foreign Missions Thank Govt for Action, Treatment for Immigration Detainees.' Malay Mail, 3 June. Accessed 16 March 2021. https:// www.malaymail.com/news/malaysia/2020/06/o3/covid-19-foreign-missionsthank-govt-for-action-treatment-for-immigration-d/1872046.

Ministry of Health. 2020a. Kenyataan Akhbar KPK 28 Februari 2020 - Situasi Terkini Jangkitan Coronavirus Disease (COVID-19) di Malaysia [Ministry of health Press Release 28 February 2020 - Latest Infection Situation on the Coronavirus Disease (COVID-19) in Malaysia]. Accessed 13 December 2020. https://kpkesihatan. com/2020/02/28/kenyataan-akhbar-kpk-28-februari-2020-situasi-terkinijangkitan-coronavirus-disease-covid-19-di-malaysia/.

-. 2020b. 'Press Statement Ministry of Health Malaysia.' Accessed 11 March 2021. http://covid-19.moh.gov.my/terkini/o52020/situasi-terkini-13-mei-2020/ Kenyataan\%2oAkhbar\%2oKPK\%2oCOVID-19\%2o(13\%2oMei\%202020)\%20 -\%2ofinal\%2o-EN.pdf. 
—. 2020c. 'Covid 19 Malaysia Updates.' COVID. Accessed 13 October, 2020. http:// covid-19.moh.gov.my/terkini.

New Straits Times. 2020. 'Govt to Subsidise Covid-19 Screening of Workers: New Straits Times.' NST Online (New Straits Times), 31 May. Accessed 4 October 2020. https://www.nst.com.my/news/nation/2020/05/596721/ govt-subsidise-covid-19-screening-workers.

Peter, Zsombor. 2020. 'Rights Groups Decry Malaysia Probe of Al Jazeera.' VOA News, 5 August. Accessed 16 March 2021. https://www.voanews.com/press-freedom/ rights-groups-decry-malaysia-probe-al-jazeera.

Rodzi, Nadirah H. 2020. 'Malaysia Raids Al Jazeera and Offices of Two Other Broadcasters in Probe on Documentary.' The Straits Times, 4 August. Accessed 19 September 2020. https://www.straitstimes.com/asia/se-asia/qatar-basedbroadcaster-al-jazeera-says-malaysian-office-raided-over-documentary.

Sandanasamy, Florida, Marja Paavilainen, and Nilim Baruah. 2020. 'COVID-19: Impact on Migrant Workers and Country Response in Malaysia.' International Labour Organization, 8 May. Accessed 2 October 2020. https://www.ilo.org/ wcmsp5/groups/public/---asia/---ro-bangkok/documents/briefingnote/ wcms_741512.pdf.

Smith, Emily Jane. 2020. "Disturbing and disappointing': Malaysia authorities block Australian journo visas.' Dateline, 7 August. Accessed 16 March 2021. https://www.sbs.com.au/news/dateline/disturbing-and-disappointing-malaysiaauthorities-block-australian-journo-visas.

Sukumaran, Tashny. 2020. 'As Malaysia Reopens, Migrants Return to the Dangers of Life in "3D".' South China Morning Post, 7 July. Accessed 3 October 2020. https://www.scmp.com/week-asia/health-environment/article/3092084/ malaysias-coronavirus-lockdown-lifts-migrant-workers.

Tan, Theng Theng, Nazihah Muhamad Noor, and Jarud Romadan Khalidi. 2020. 'Covid-19: We Must Protect Foreign Workers.' Khazanah Research Institute Discussion Paper 8/20, 5 June. Accessed 17 March 2021. http://www.krinstitute.org/assets/contentMS/img/template/editor/20200607_Discussion\%20 Paper_Covid-19_We\%2oMust\%2oProtect\%2oForeign\%2oWorkers_Rev.pdf.

Tang, Kuok Ho Daniel. 2020. 'Movement Control as an Effective Measure against Covid-19 Spread in Malaysia: An Overview.' Journal of Public Health: 1-4. https:// doi.org/10.1007/s10389-020-01316-w.

The Star. 2020. 'Reconsider Entry Ban, Malaysia Urged.' The Star Online, 4 September. Accessed 5 October 2020. https://www.thestar.com.my/news/nation/2020/09/05/ reconsider-entry-ban-malaysia-urged.

Yunus, Arfa. 2020. 'Explain Our Side of the Story, Says Dr M on Al Jazeera Report.' New Straits Times, 21 July. Accessed 16 March 2021. https://www.nst.com.my/ news/nation/2020/07/610396/explain-our-side-story-says-dr-m-al-jazeera-report. 


\section{About the Authors}

Nurliana KAMARUDDIN is Deputy Executive Director (Academic) at the Asia-Europe Institute, Universiti Malaya. She obtained her PhD in International Studies from Ewha Womans University, specializing in Development Cooperation. Her area of research includes international politics and development with a focus on ASEAN and East Asian relations. Kamaruddin was a recipient of the Korea Foundation ASEAN Fellowship (2013-2015), the POSCO TJ Park Foundation Asia Fellowship (2009-2011) and the Ewha Global Partnership Program scholarship (2006-2009). Prior to her appointment as Senior Lecturer at the Asia-Europe Institute (AEI), Nurliana was a Research Assistant at the AEI (2011-2013). Before that, she was a lecturer at the English Language Centre, Stamford College, Selangor (2009). Nurliana is the co-editor of the book ASEAN Post 5o:Emerging Issues and Challenges (Palgrave Macmillan, 2019).

Zokhri IDRIS has held several academic positions in International Relations (IR) research and teaching, and now is the Deputy Dean of Student Affairs at the Management and Science University (MSU) in Malaysia. He served as a senior faculty member in the Faculty of Business Management and Professional Studies (FBMP), MSU after completing his industrial attachment at Puncak Niaga Management Services as an assistant manager serving the Strategic Resources and Public Relations Division. His research focuses on the changing nature of diplomacy and sovereignty of developing nations, especially Malaysia. This led him to the establishment of the Eirene Research website, to explore leadership and diplomacy in International Relations. He co-founded ARUS, an avenue to nurture talent and empower Malaysian youth. Currently, he serves the Institute of Democracy and Economic Affairs, Malaysia (IDEAS) as Director of External Relations. 



\title{
10 Analysis of South Korea's Experience with the COVID-19 Pandemic and its Relations with the WHO
}

\author{
Eun Mee KIM and Jisun SONG
}

\begin{abstract}
This chapter analyses South Korea's experience in combating the COVID-19 pandemic internationally in the context of the government's global outreach and development cooperation for developing countries, and the public's response to global health governance centring on the World Health Organization (WHO). The findings indicate that the South Korean government quickly embraced multilateralism in its COVID-19 response. It did so by providing financial contributions to key global health initiatives for fair and equal access to COVID-19 vaccines, by creating global platforms for dialogue, and by enhancing its participation in global health institutions. However, analysis of South Korean media editorials indicates that, in contrast with the government, the South Korean public showed discontent with the WHO.
\end{abstract}

Keywords: South Korea (Republic of Korea), World Health Organization, global health governance, development cooperation, multilateralism, COVID-19

\section{Introduction}

South Korea has stood out as an exemplary country in the battle against COVID-19, handling the virus without going through a lockdown. After the first cases of COVID-19 in China were reported in December 2019, the South Korean government was on high alert due to the geographic proximity

Van der Veere, Anoma P., Florian Schneider, and Catherine Yuk-ping Lo (eds), Public Health in Asia during the COVID-19 Pandemic: Global Health Governance, Migrant Labour, and International Health Crises. Amsterdam, Amsterdam University Press 2022 DOI: 10.5117/9789463720977_CH10 
between the two countries. It was on 20 January 2020 that the first COVID-19 case was confirmed in South Korea. Since then, South Korea has encountered several hurdles in its fight against COVID-19. The number of COVID-19 patients gradually increased after this first case. On 18 February 2020, the country saw a sudden spike in the infection number due to a large cluster of cases associated with the Shincheonji Church of Jesus in Daegu, the fourth most populated city in the country. The spread of the coronavirus related to this cluster was eventually contained. However, South Korea witnessed a second major outbreak in late August and early September. On 15 August 2020, the National Liberation Day, a number of infected individuals participated in a large-scale political protest organized by far-right church members in Seoul. This resulted in the spread of the coronavirus across the country. However, South Korea was able to flatten the curve in a relatively short time.

In responding to COVID-19 domestically, the South Korean government has implemented an array of policies and strategies, including tracking, treatment, self-quarantine, immigration, and social distancing. It has adopted a whole-of-government approach, which implies a horizontally and vertically coordinated approach from different government stakeholders. At the same time, the South Korean government's approach has closely followed the recommendations of the World Health Organization (WHO), particularly in terms of limiting travel and trade to and from countries that are undergoing COVID-19 outbreaks (WHO 2020a). The WHO's recommendations emphasize the need to refrain from imposing excessive entry restrictions. The South Korean government even issued a statement with other United Nations (UN) member countries on the need for a global, coordinated response to avoid unnecessary interference with international traffic and trade while taking into account the movement of goods and people for humanitarian, scientific, and essential business purposes, so long as this does not undermine a country's disease control (MOFA 2020c; 2020e).

South Korea has also focused on its responsibility towards other members of the international community. As a member of the Development Assistance Committee (DAC) of the Organization of Economic Development and Cooperation (OECD), South Korea has a responsibility as a donor country to assist its partner countries in developing regions, particularly during the pandemic. South Korea has increased its financial contributions to international organizations as well as global initiatives on health. It has also established platforms for dialogue on global health.

This chapter will analyse South Korea's experience combating COVID-19, in terms of the government's domestic response and its international 
contributions, and the South Korean public's response to the role of the WHO since the outbreak began. First, it will examine the South Korean government's global outreach with a focus on development cooperation for partner countries during the COVID-19 outbreak. Second, it will look at the responses to global health governance and the WHO of the South Korean government and public. It will examine the government's standpoint on the role of the $\mathrm{WHO}$ as a global health institution and its contribution to strengthening global health governance since the COVID-19 pandemic began. The chapter will also pay attention to the South Korean public's response to, and debates about, the role of the WHO during the COVID-19 pandemic. This chapter shows that there has been a concerted and coordinated effort by the South Korean government to strengthen the role of multilateral health institutions, including the WHO. However, public sentiment has been contrary to this, particularly regarding the WHO's management of the situation and its position towards China.

\section{South Korea's Health Multilateralism}

The South Korean government's global contribution to combating the COVID-19 pandemic involves: (1) its financial contribution to global health initiatives that are dedicated to the eradication of global infectious diseases including COVID-19; and (2) its creation of global platforms to create stronger partnerships and dialogue on diseases.

First, South Korea has made contributions to several global health initiatives, including the Coalition for Epidemic Preparedness Innovations (hereafter, CEPI), Gavi, the Vaccine Alliance (hereafter, Gavi), the Global Fund to Fight AIDS, Tuberculosis and Malaria (hereafter, Global Fund), and Unitaid, an innovative financing initiative to scale up access to medicines. Different global health initiatives are playing pivotal roles in providing global, rapid, and equitable access to COVID-19 vaccines at affordable prices, especially for developing countries. For instance, CEPI acts as a global mechanism for financing COVID-19 vaccine development, while Gavi helps to provide vaccines at a more affordable price for developing countries (Yamey et al. 2020).

South Korea is currently participating in the decision-making body of all three initiatives listed above. It is an independent member of the executive board for Unitaid, a non-voting member of the 'additional public donors' group on the board of the Global Fund, and a member of the Gavi board along with the United States, Australia, and Japan. For Gavi, the four-country 
group is currently represented by Australia, and Australia will hold the vice-chair seat until the end of 2021. In 2020, South Korea announced its first contributions to CEPI. Although South Korea's motives for funding such initiatives have not been made explicit, its decision to contribute to these initiatives may be influenced, amongst other things, by the way the programmes align with South Korea's Official Development Assistance (ODA) priorities, the effectiveness and impact of the initiatives, and the economic opportunities they offer for South Korean private companies (MOFA 2015).

Table 10.1 shows the size of the financial contributions that the South Korean government has made to the four global health initiatives, as well as its core funding to the WHO. South Korea's funding to CEPI, Gavi, Global Fund, and Unitaid is financed by the Global Disease Eradication Fund (GDEF). This is an innovative finance mechanism based on the air-ticket solidarity levy system in South Korea. The GDEF is managed by the Ministry of Foreign Affairs, and the foreign minister has announced an increase of funding in the coming years to help the global response to COVID-19. However, South Korea has already increased its commitments to these initiatives since the start of the COVID-19 crisis. For instance, South Korea's contribution to Gavi increased from an average of US $\$ 5$ million per year to US $\$ 6$ million per year, providing a total of US $\$ 30$ million in the period from 2021 to 2025 (MOFA 2020b). Last year, it also contributed to funding CEPI for the first time, giving it an average of US $\$ 3$ million per year (MOFA 2020a, 14). Despite an increase in financial contributions, the amounts that South Korea is giving to these initiatives is relatively small when compared to other major donors. For instance, South Korea's pledge to CEPI was US\$9 million, which is lower than the pledges of the US (US\$20 million), Norway (US\$25 million), and the UK (US\$296 million), but higher than those of Austria (US\$2.3 million), Denmark (US\$1.4 million), and Finland (US\$4.5 million) (The Economist 2021). South Korea is also one of the five donors to Unitaid. In addition, it is a small donor in the larger global health initiatives, such as the Global Fund, to which it provided US $\$ 3.7$ million in 2018 , in contrast with the US and France which provided US $\$ 959$ million and US\$424 million respectively (OECD 2021).

South Korea's assessed contribution to the WHO, which is determined by the country's income level, is primarily managed by the Ministry of Health and Welfare. The Ministry of Foreign Affairs and the Ministry of Environment also fund WHO projects. ${ }^{1}$ Between 2020 and 2021, South Korea's

1 Funding for the WHO is different from that of the other global health initiatives mentioned above (e.g. CEPI, Gavi) as it is measured by the donor's income level. While the Ministry of 
Table 10.1 South Korea's Contributions to the Global Health Initiatives

\begin{tabular}{ll}
\hline Initiative & Pledge \\
\hline CEPI & $-(2020-2022)$ US\$9 million \\
Gavi & $-(2019-2021)$ US\$15 million \\
Global Fund & $-(2021-2025)$ US\$30 million \\
& $-(2017-2019)$ US\$12.5 million \\
WHO & $-(2020-2022)$ US\$25 million \\
& $-(2021)$ Core contribution of KRW10 billion (US\$8.9 million) \\
Unitaid & $-(2017-2019)$ US\$8 million (US\$4 million annually) \\
& $-(2019-2021)$ US\$15 million (US\$5 million annually) \\
\hline
\end{tabular}

Note: Currency converted from Korean Won (KRW) to US Dollars based on the exchange rate from Oanda.com website, converted on Oct 24, 2020.

Source: MOFA (2019a; 2019b; 2020a; 2020b); CIDC (2020a; 2020b).

assessed funding to the WHO remained constant at around US $\$ 9$ million (CIDC 2020a, 28; 2020b, 36).

Another major way in which South Korea makes financial contributions to global partnerships for responding to infectious diseases is through its official development assistance (ODA). South Korea has been committed to increasing its ODA budget since joining the OECD DAC in 2010. Although South Korea's ODA as a proportion of Gross National Income (GNI) was only $0.15 \%$ in 2019 , which is far below the global target of $0.7 \%$, it aims to reach $0.3 \%$ ODA/GNI by 2030 (CIDC 2020a, 7). During the pandemic, the South Korean government announced that it would increase its total ODA budget by $19 \%$ (i.e., by 652.3 billion Korean won or US $\$ 577$ million), from 3427 billion won (US $\$ 3$ billion) in 2020 to 4079 billion won (US $\$ 3.6$ billion) in 2021 (CIDC 2020b, 29). This announced increase was made despite the fact that the International Monetary Fund projected South Korea's real GDP growth rate to be $-1.9 \%$ in 2020 (IMF 2020, 56).

More specifically, South Korea increased health-related ODA by $33.7 \%$ (93.4 billion won or US $\$ 83$ million) from 277.3 billion won (US $\$ 245$ million) in 2020 to 370.7 billion won (US\$328 million) in 2021. This increase was made to help its ODA recipient countries respond to COVID-19. At the same time, the South Korean authorities are going to partner with Korean civil society organizations and the private sector to tap into diverse forms of development finance. For instance, a group of South Korean non-government 
Figure 10.1 South Korea's ODA Trend for 2015-2021

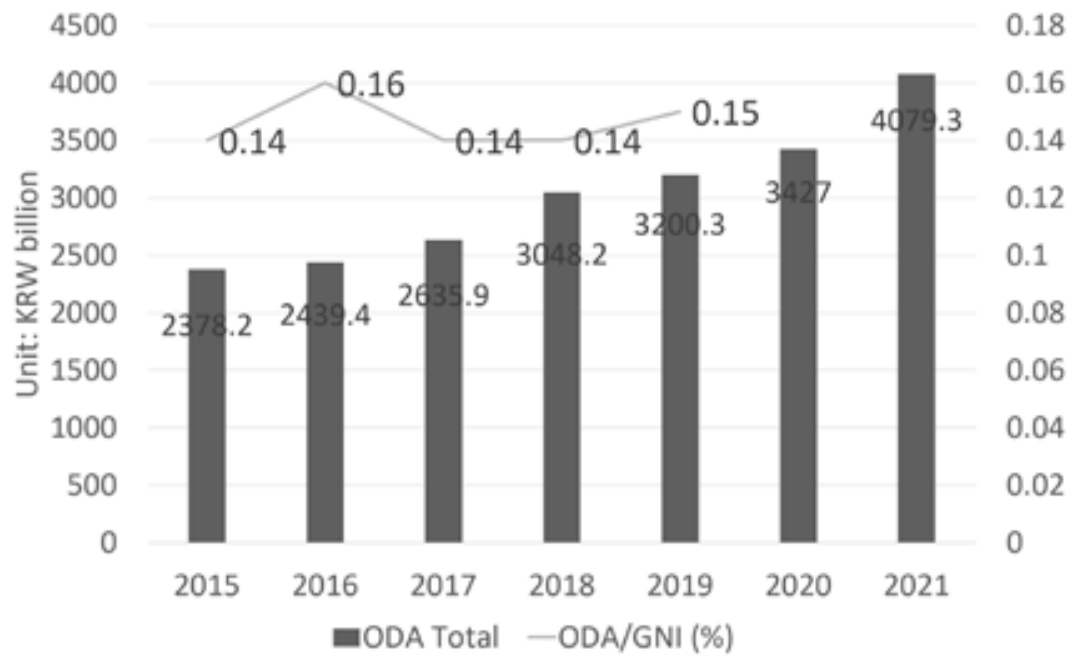

organizations that focus on international development announced a plan to allocate 60 billion won (US\$53 million) to around 60 partner countries to mitigate the impact of COVID-19 (CIDC 202ob, 13). Moreover, at the WHO's World Health Assembly on 18 May 2020, the South Korean government declared that it would contribute US\$100 million in humanitarian assistance to help developing countries tackle the outbreak (GoK 2020a). Increasing humanitarian aid is in line with South Korea's aim of carving out its role as a middle power while responding to the growing demand in partner countries (CIDC 202ob, 3).

In addition to the monetary contributions, South Korea is participating in multilateral platforms that aim to provide fair and equitable access to COVID-19 vaccines for all countries, regardless of the level of economic development. For example, South Korea participates in the COVAX Facility, which is a global collaboration co-led by CEPI, Gavi, and the WHO to assure the development and equitable distribution of COVID-19 vaccines (Yonhap 2020). The South Korean government has urged other countries to do the same. It also provided US\$10 million to COVAX Advance Market Commitment (AMC) for developing countries' better access to COVID-19 vaccines (MOFA 2020e). South Korea is also a facilitation council member of the Access to COVID-19 Tools Accelerator (ACT-A), which was co-launched by the WHO, European Commission, France, and the Bill \& Melinda Gates Foundation (KBS World 2020; WHO 2020b). 
Table 10.2 Global Solidarity Groups on COVID-19 Launched by South Korea

\begin{tabular}{|c|c|c|}
\hline Date & Name & Participating Countries \\
\hline May 12,2020 & $\begin{array}{l}\text { UN Group of Friends of Solidarity for } \\
\text { Global Health Security }\end{array}$ & $\begin{array}{l}\text { - Co-chairs: South Korea, Canada, } \\
\text { Denmark, Qatar, Sierra Leone }\end{array}$ \\
\hline May 20, 2020 & $\begin{array}{l}\text { WHO Support Group for Global } \\
\text { Infectious Disease Response (G4IDR) }\end{array}$ & $\begin{array}{l}\text { - Core-members: South Korea, Kenya, } \\
\text { Mexico, Morocco, Peru, Singapore, } \\
\text { Turkey, United Arab Emirates }\end{array}$ \\
\hline May 26, 2020 & $\begin{array}{l}\text { UNESCO Group of Friends for } \\
\text { Solidarity and Inclusion with Global } \\
\text { Citizenship Education (GCED) }\end{array}$ & $\begin{array}{l}\text { - Inaugural members: South Korea } \\
\text { (Chair), Armenia, Austria, Bang- } \\
\text { ladesh, Colombia, Italy, Jordan, } \\
\text { Kenya, Philippines, Serbia, Senegal }\end{array}$ \\
\hline
\end{tabular}

Source: MOFA (2020f; 2020g; 2020h) .

Furthermore, in May 2020 South Korea launched three global solidarity groups contributing to the COVID-19 response at the UN, WHO, and UNESCO. The UN Group of Friends of Solidarity for Global Health Security is dedicated to strengthening the UN's response to health security issues, including COVID-19. The WHO group seeks to build an effective global infectious disease response system. Meanwhile, the UNESCO group aims to galvanize global cooperation and discussion on discrimination and other forms of inhumane acts provoked by COVID-19. South Korea participates as a chair or core-member of all three platforms, which are open to all countries. In addition to this, on 19 May 2020 South Korea was chosen to serve as a WHO executive member in the period from 2020 to 2023, with the South Korean Vice Minister of Health and Welfare acting as the representative. Participation in such multilateral platforms can consolidate the country's influence as a global agenda-setter. For instance, by proactively participating in board meetings where budgets, programmes, and strategies are discussed, South Korea is able to ensure that its own agenda is reflected in these organizations' decision-making processes (MOHW 2020).

As one of the countries severely affected by COVID-19, South Korea has quickly and effectively reacted to the outbreak to prevent further spread of the disease domestically. At the same time, the above analysis has shown how it has taken a proactive role in contributing to the global discussion and cooperation in responding to COVID-19. It has done this by utilizing existing global health initiatives and increasing its financial contributions to these, as well as by establishing multilateral arenas for the discussion of global health security. 


\section{South Korea's Reactions to the COVID-19 Measures of the WHO}

As part of its strategy to tackle COVID-19 domestically, South Korea has followed the WHO's recommendations while making necessary adjustments. However, the South Korean public has displayed negative reactions to the WHO's slow response and the position of the organization towards China.

To assess the South Korean public's attitudes towards the WHO, we analysed editorials published by domestic news agencies between 20 January 2020, when the first case of COVID-19 was reported in South Korea, and 18 October 2020. Although editorials are based on the authors' opinions, there is not only room for such pieces to influence public policy (Sommer and Maycroft 2008), but these can also act as a mechanism in shaping the agenda and public opinion (Coppock, Ekins, and Kirby 2018). Our study therefore assumes that the editorials represent public opinion to a certain degree.

We obtained the editorials using the Big Kinds database run by the Korea Press Foundation, which stores all the articles written in either Korean or English that have been published by 54 different news agencies. We searched for all editorials using the keywords 'WHO' or 'World Health Organization' in both Korean and English. The first search generated 324 editorials, which we cross-reviewed to determine if the respective editorials were about COVID-19. Editorials that were irrelevant to COVID-19 and South Korea were omitted. This led to the removal of 44 articles. Then, we reviewed the full text of each editorial and narrowed down the number by removing any editorials that did not have an opinion on the WHO. That is, editorials that simply quoted the WHO's data or statements were removed. A total of 262 editorials were omitted from this second screening and the remaining eighteen editorials were analysed. All articles were written in Korean and we translated the contents as literally as possible to best convey the original message. The eighteen pieces are summarized in Table 10.3 with the key events that influenced the tone and content of the editorials.

Public reactions to the WHO were seen after the following events: the initial outbreak of COVID-19, the South Korean government's declaration of COVID-19 as a Public Health Emergency of International Concern (PHEIC) and subsequently as a pandemic, and also the suspension of funding to the WHO by then US President Trump. The media and the public especially criticized the WHO's position towards China when the first case was recorded. They were also critical, to a lesser extent, of the WHO's approach 


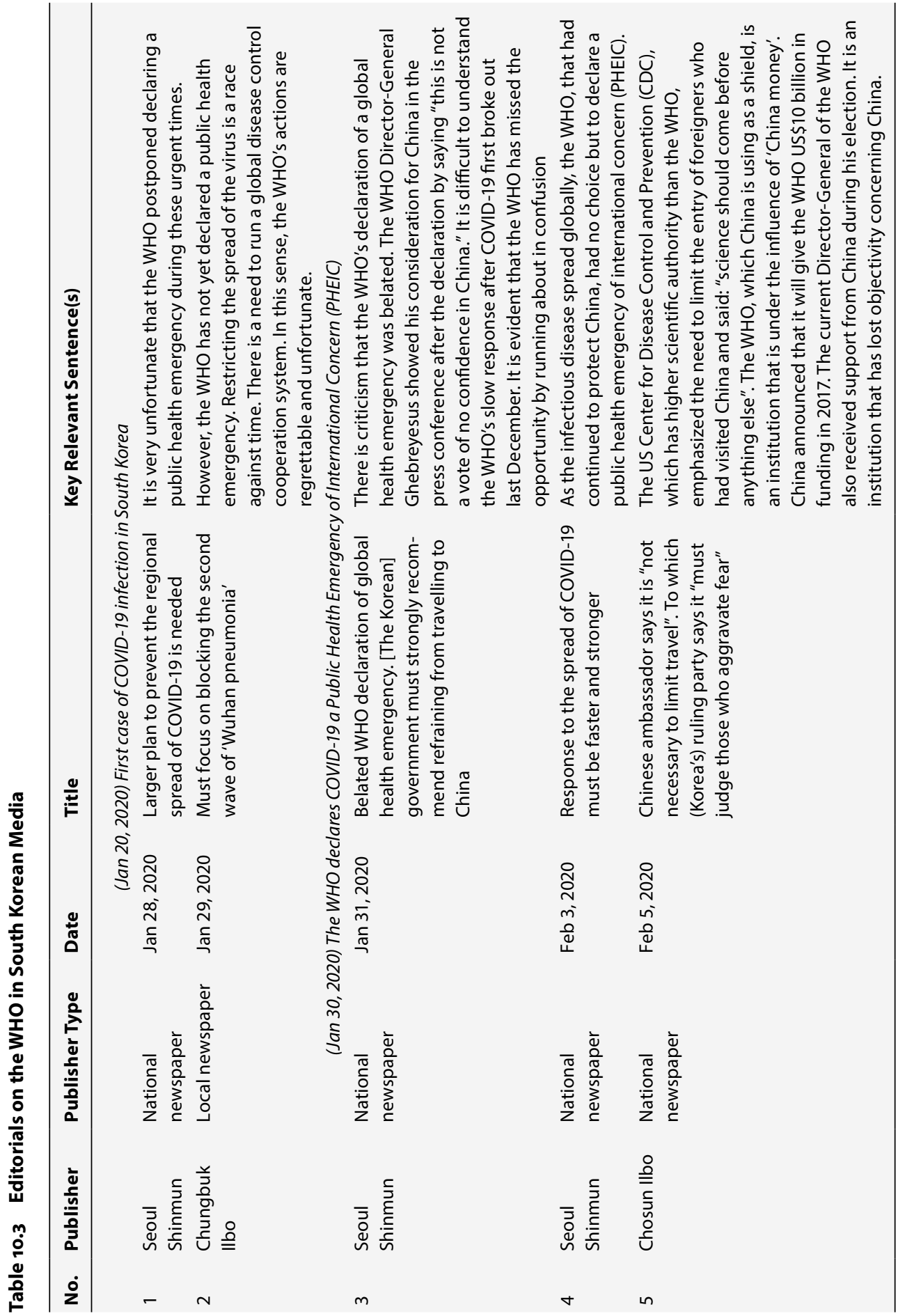




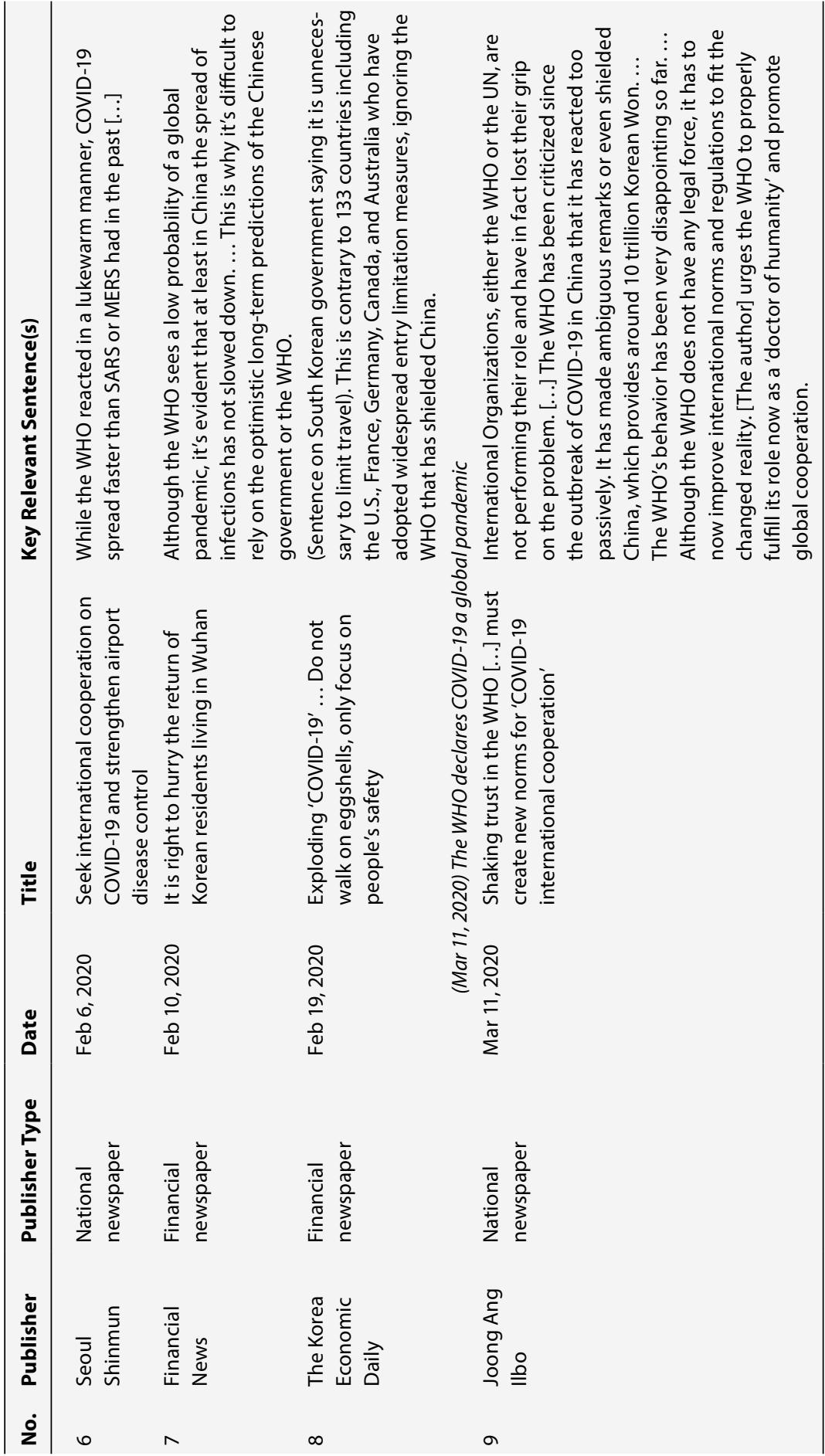




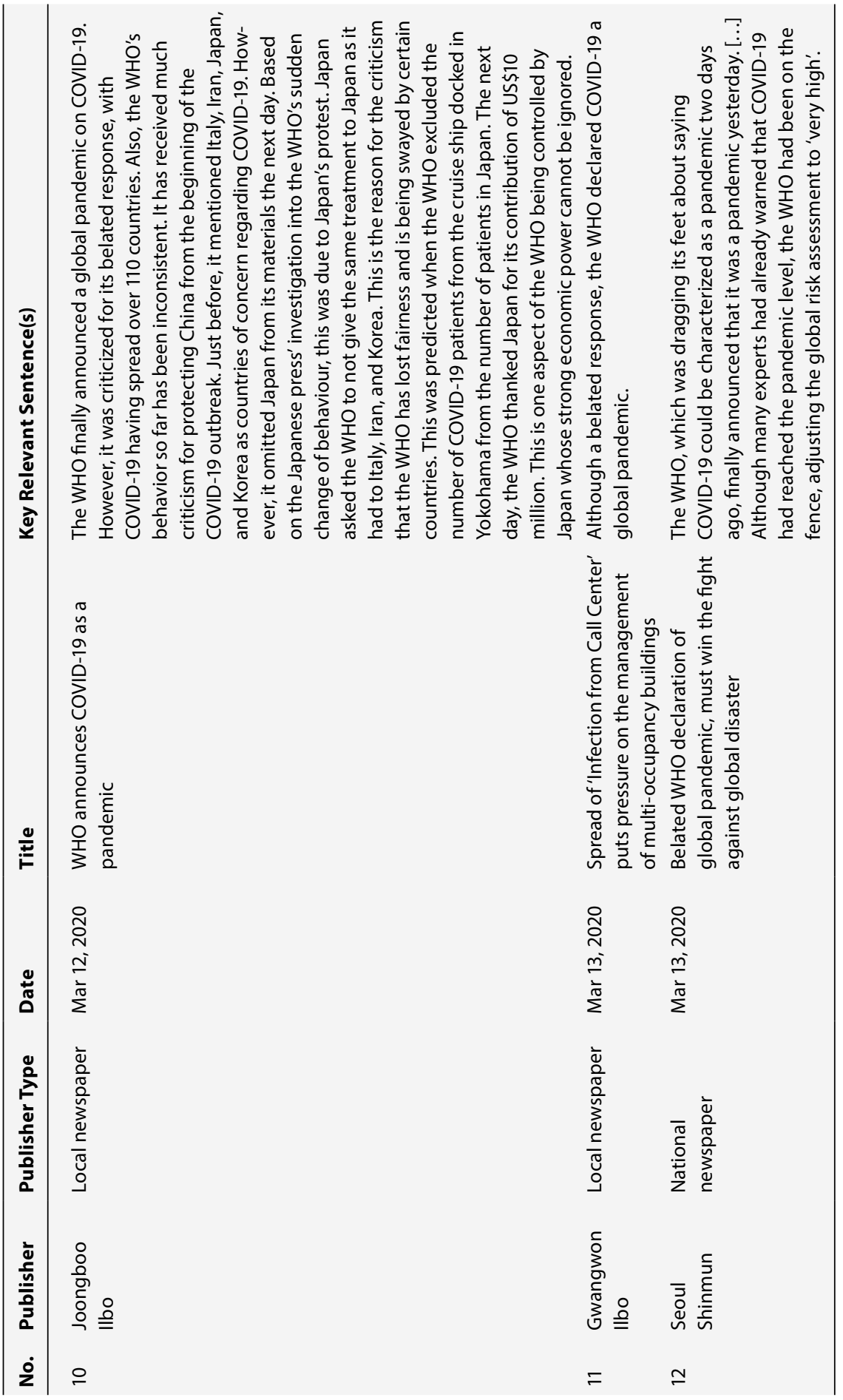




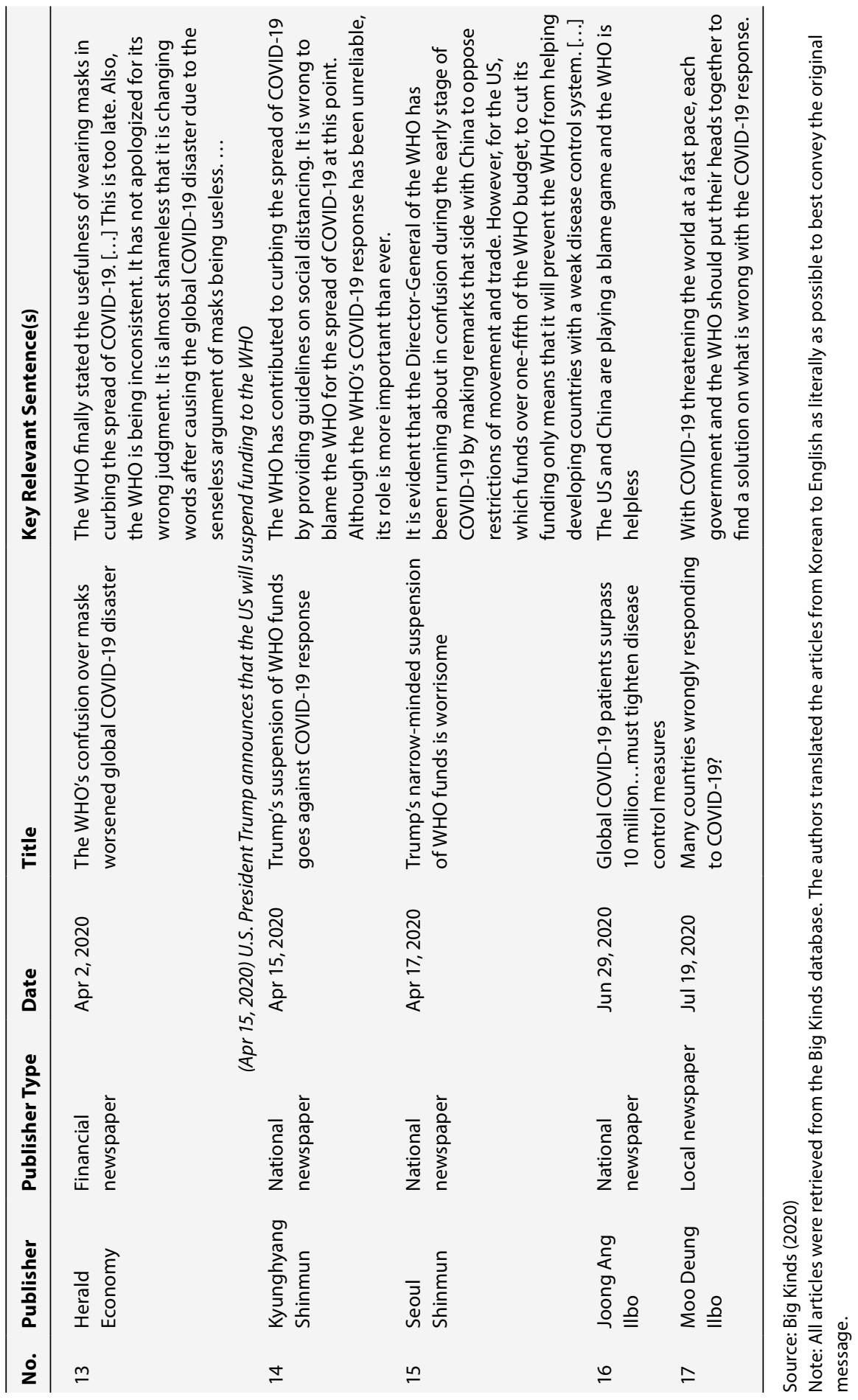


to Japan and the way it had downplayed the number of COVID-19 cases by not including the number of infected patients on the Diamond Princess cruise ship that departed from Yokohama in Japan.

Soon after the first case of infection was reported in China, the South Korean media urged the WHO to announce a PHEIC. The media viewed the delay in the announcement of this as the result of the close political relationship between the WHO, especially the WHO Director-General, and the Chinese government. This view was found in most of the editorials published during February 2020 that were analysed. Due to its geographical proximity to China, which meant a large number of people travelled between the two countries, the media criticized the WHO for not recommending strong travel restrictions. They also criticized the South Korean government for following the WHO's recommendations while other countries had done the opposite and had limited the entry of people from China. This latter view was reflected in editorials 3 and 8 . Most editorials, published in both conservative and liberal newspapers, criticized the role of the WHO during the crisis. Several editorials (i.e., numbers 3,6 , and 7 ) even condemned the WHO for aggravating the situation.

Even after the WHO declared COVID-19 a pandemic in March 2020, the editorials published at the time unanimously criticized this as being a belated response. The WHO's conflicting guidelines on wearing masks also confused the public. The WHO had stated that a 'medical mask is not required for people who are not sick as there is no evidence of its usefulness in protecting them' (WHO 2020a). In contrast, the South Korean government strongly recommended wearing masks in public places.

A change in the tone of the editorials emerged when the then US President Trump announced the suspension of funding to the WHO. After this, while acknowledging the limitations of the actions taken by the WHO, the editorials also stated that for a major donor like the US to pull back its large funding was unfair and would set back global COVID-19 responses. These editorials argued that the contributions of the donor countries were important for helping the international community, and particularly developing countries, fight the pandemic (see editorials numbers 14-17).

The South Korean government has maintained its political support for the WHO and voiced concerns over diminishing support for multilateral platforms including the WHO. Table 10.4 shows that the messages coming from President Moon Jae-in have been consistent, expressing the government's support for the WHO at both domestic and international events. In a joint op-ed published with the heads of eight countries including Canada 
Table 10.4 Remarks from President Moon, Jae-in on the WHO

\begin{tabular}{|c|c|c|}
\hline Date & Event & Relevant Remarks \\
\hline $\begin{array}{l}\text { Mar 26, } \\
2020\end{array}$ & $\begin{array}{l}\text { Remarks at the G20 } 2020 \\
\text { Extraordinary Virtual } \\
\text { Leaders' Summit }\end{array}$ & $\begin{array}{l}\ldots \text { in accordance with the WHO's recommenda- } \\
\text { tion, we minimized restriction on cross-border } \\
\text { movements of people and goods... }\end{array}$ \\
\hline $\begin{array}{l}\text { Apr 6, } \\
2020\end{array}$ & $\begin{array}{l}\text { Phone call with the WHO } \\
\text { Director-General }\end{array}$ & $\begin{array}{l}\text {... we are minimizing unnecessary restrictions on } \\
\text { the movement of people and goods in line with } \\
\text { the WHO's recommendations. [...] In the face of } \\
\text { this unprecedented global healthcare crisis, the } \\
\text { role of the WHO is becoming more important. } \\
\text { I hope that the WHO will play a leading role in } \\
\text { eradicating COVID-19 by taking active counter- } \\
\text { measures through international unity... }\end{array}$ \\
\hline $\begin{array}{l}\text { Apr 9, } \\
2020\end{array}$ & $\begin{array}{l}\text { Remarks at a joint meeting } \\
\text { on COVID-19 treatments } \\
\text { and vaccines held } \\
\text { domestically }\end{array}$ & $\begin{array}{l}\text { [...] Korea will actively participate in the } \\
\text { international community's efforts to surmount } \\
\text { the COVID-19 outbreak through a cooperative } \\
\text { system led by the WHO and the UN. }\end{array}$ \\
\hline $\begin{array}{l}\text { Apr 24, } \\
2020\end{array}$ & $\begin{array}{l}\text { Phone call with the } \\
\text { President of South Korea }\end{array}$ & $\begin{array}{l}\text { The two leaders agreed that it is necessary to } \\
\text { assist the WHO so that it can fulfill its role. }\end{array}$ \\
\hline $\begin{array}{l}\text { May } 18, \\
2020\end{array}$ & $\begin{array}{l}\text { Address at the 73rd World } \\
\text { Health Assembly }\end{array}$ & $\begin{array}{l}\text { Second, in order to develop vaccines and treat- } \\
\text { ments, we must cooperate beyond our borders. } \\
\text { [...] The Republic of Korea fully supports the } \\
\text { efforts of the WHO to develop vaccines and treat- } \\
\text { ments.... We must update the WHO International } \\
\text { Health Regulations and other relevant norms and } \\
\text { augment them with binding legal force. }\end{array}$ \\
\hline $\begin{array}{l}\text { Jul 16, } \\
2020\end{array}$ & $\begin{array}{l}\text { Joint op-ed in the } \\
\text { Washington Post with the } \\
\text { heads of Canada, Ethiopia, } \\
\text { New Zealand, South Africa/ } \\
\text { AU, Spain, Sweden, and } \\
\text { Tunisia }\end{array}$ & $\begin{array}{l}\text { Thankfully, great efforts, investment and coordi- } \\
\text { nation, largely facilitated by the WHO, are being } \\
\text { directed at putting an end to the pandemic. [....] A } \\
\text { fair and effective vaccine allocation mechanism, } \\
\text { guided by WHO advice and based on needs } \\
\text { rather than means, should focus on saving lives } \\
\text { and protecting health systems.... We particularly } \\
\text { recognize the WHO's role as the leading global } \\
\text { health agency... }\end{array}$ \\
\hline
\end{tabular}

Source: GoK (2020a; 2020b; 2020c; 2020d; 2020e); Trudeau et al. (2020).

and Ethiopia, leaders specifically pinpointed the WHO as the leading global health agency in fighting the current pandemic.

Other ministers, including the Minister of Foreign Affairs and the Minister of Health and Welfare, have echoed this support for the role of the WHO. For instance, at the Annual Reunion of Romanian Diplomacy, which was held on 8 September 2020, the South Korean Foreign Minister Kang Kyung-wha expressed concerns over the divisive dynamics of WHO member states and emphasized the need to 'prize, respect and enhance the WHO's technical 
and scientific expertise' (MOFA 2020b). This shows how the South Korean government, unlike the media and the public, has not wavered in its position on the WHO. Instead, throughout the outbreak it has called for a further strengthening of the institution.

The difference in attitude between the South Korean government and society at large can be explained by the South Korean government's aim to solidify its role as a middle power country and augment its leadership in multilateral platforms. In other words, although South Korea lacks the influence of a major power such as the United States, the current administration has aimed to reinforce international cooperation through diplomacy by utilizing various regional and global arenas (GoK 2017). As such, despite the negative public sentiment, support for health multilateralism is aligned with the government's diplomatic priorities. In addition, the public sentiment towards the WHO has turned less critical and more supportive as the pandemic has progressed. This means that the initial difference in the views of the government and the public is unlikely to have any consequential impact on South Korea's relationship with the WHO.

\section{Conclusion}

Given the international community's efforts to combat COVID-19, this chapter looked specifically at South Korea's efforts to strengthen global health security by offering foreign assistance and participating in multilateral platforms. South Korea has not only increased its bilateral and multilateral assistance, but it has also created new venues for global discussion and cooperation on global health issues. At the same time, the chapter examined the contrasting opinions of the South Korean government and the public about the WHO and its responses to COVID-19. The analysis shows that while there had been severe criticism of the WHO's leadership and its early responses, the public became more supportive of the WHO's role in the global response after the US suspended financial contributions to the health organization. Contrary to the shifting public opinion, the South Korean government has displayed consistent support for the WHO and its guidelines, while at times being criticized by the public for abiding by the WHO's recommendations. This implies that the South Korean government's goal of fortifying its global leadership in multilateral organizations took priority over appeasing domestic public opinion. 


\section{References}

Big Kinds. 2020. 'Big Kinds Database.' Accessed 21 October 2020. https://www. bigkinds.or.kr/.

Committee for International Development Cooperation (CIDC). 2020a. '2020 Gukjegaebalhyeopryeok Jonghapsihaenggyehoek (hwagjeongaeg gijun) [2020 International Development Cooperation Action Plan (Final Budget)].' Republic of Korea: Committee for International Development Cooperation.

—. 202ob. '2021 Gukjegaebalhyeopryeok Jonghapsihaenggyehoek(an) (Yoguaek gijun) [2021 International Development Cooperation Action Plan (Proposed Budget)].' Republic of Korea: Committee for International Development Cooperation.

Coppock, Alexander, Emily Ekins, and David Kirby. 2018. 'The Long-Lasting Effects of Newspaper Op-Eds on Public Opinion.' Quarterly Journal of Political Science vol. 13, no. 1: 59-87. http://dx.doi.org/10.1561/100.00016112.

GoK. 2017. '1oodae Gukjeonggwaje: Moon Jae-in Jeongbu Gukjeongunyeong 5gaenyeon Gyehoek [10o Policy Tasks: Five-Year Plan of the Moon Jae-in Administration].' The Government of the Republic of Korea.

- 2020a. 'Address by President Moon Jae-in to the 73rd World Health Assembly.' Republic of Korea: Cheong Wa Dae, 19 May. Accessed 5 November 2020. http:// english1.president.go.kr/Contents/Infographics/94?page=9.

- 202ob. 'Remarks by President Moon Jae-in at G2o 2020 Extraordinary Virtual Leaders Summit.' Republic of Korea: Cheong Wa Dae, 26 March. Accessed 5 November 2020. https://english1.president.go.kr/Briefingspeeches/Speeches/786.

—. 2020c. 'Remarks by President Moon Jae-in at Joint Meeting with Industry, Academia, Research Institutions and Hospitals to Develop COVID-19 Treatments and Vaccine.' Republic of Korea: Cheong Wa Dae, 9 April. Accessed 5 November 2020. https://english1.president.go.kr/BriefingSpeeches/COVID-19/796.

- 202od. 'The President Speaks by Phone to President of Republic of South Africa Cyril Ramaphosa.' Republic of Korea: Cheong Wa Dae, 24 April. Accessed 5 November 2020. https://english1.president.go.kr/BriefingSpeeches/Briefings/519.

- 2020e. 'The President Speaks by Phone to WHO Director-General Tedros Adhanom Ghebreyesus.' Republic of Korea: Cheong Wa Dae, 6 April. Accessed on 5 November 2020. https://english1.president.go.kr/BriefingSpeeches/ Briefings/506.

IMF. 2020. World Economic Outlook, October 2020: A Long and Difficult Ascent. International Monetary Fund. Accessed 5 November 2020. https://www.imf.org/ en/Publications/WEO/Issues/2020/o9/30/world-economic-outlook-october-2020.

KBS world. 2020. 'S. Korea Joins COVID-19 Global Response Organization.' 11 September. Accessed 25 October 2020. https://world.kbs.co.kr/service/news_view. htm?lang=e\&Seq_Code $=\mathbf{1 5 6 1 9 9}$. 
Ministry of Foreign Affairs (MOFA). 2015. 'Bodojaryo: Hanguk, Segyebaeksinmyeo nyeokyeonhap(GAVI)e 3nyeongan chong 1,200manbul jiwon gyeoljeong [Press Release: South Korea Agrees to Provide US\$12 Million to GAVI over Three Years].' Republic of Korea: Ministry of Foreign Affairs. Accessed 25 October 2020. http:// www.mofa.go.kr/www/brd/m_408o/view.do?seq=356572.

—. 2019a. 'Bodojaryo: Jeon Segye Aids, gyeolhaek, malaria toechireul wihan gongyeoyakjeong chegyeol [Press Release: South Korea Signs Contribution Agreement for Global Eradication of AIDS, TB and Malaria].' Republic ofKorea: Ministry of Foreign Affairs. Accessed 25 October 2020. http://www.mofa.go.kr/ www/brd/m_4080/view.do?seq=36980o.

—. 2019b. 'Bodojaryo: Gukjeuiyakpumgigu(Unitaid) je32chajiphaengisahoe gaechoe (Press Release: Unitaid Organizes 32nd Executive Board Meeting).' Republic of Korea: Ministry of Foreign Affairs. Accessed 25 October 2020. http://www.mofa. go.kr/www/brd/m_408o/view.do?seq=369293.

—. 2020a. '2020 Juyoeopmu Chujingyeheok [2020 Ministry of Foreign Affairs Major Work Plan].' Republic of Korea: Ministry of Foreign Affairs.

—. 2020b. 'Bodojaryo: Kang Kyung-wha Janggwan, Corona19 Daeeung Gigeum Josung Hoeui Chamseok [Press Release: Minister Kang, Kyung-Wha Attends COVID-19 Global Response Conference].' Republic of Korea: Ministry of Foreign Affairs. Accessed 25 October 2020. http://www.mofa.go.kr/www/brd/m_4080/ view.do?seq=370177.

—. 2020c. 'Bodojaryo: Kang Kyung-wha Janggwan, 2020 Global Vaccine Jeongsanghoeui Chamseok [Press Release: Minister Kang, Kyung-Wha Attends Global Vaccine Summit 2020].' Republic of Korea: Ministry of Foreign Affairs. Accessed 25 October 2020. http://www.mofa.go.kr/www/brd/m_4080/view. do?seq=370255.

-. 2020d. 'Press Release: Minister of Foreign Affairs Holds Telephone Conversation with Her Counterparts of Countries Affected by COVID-19 on Response to COVID-19.' Republic of Korea: Ministry of Foreign Affairs. Accessed 25 October 2020. http://www.mofa.go.kr/eng/brd/m_5676/view.do?seq=321018.

—. 2020e. 'Press Release: ROK Government Pledges US $\$ 10$ Million to COVAX AMC.' Republic of Korea: Ministry of Foreign Affairs. Accessed 25 May 2021. https://www.mofa.go.kr/eng/brd/m_5676/view.do?seq=321311\&srchFr=\&amp

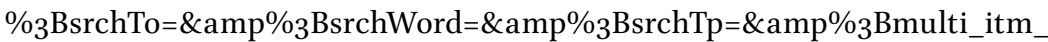
seq=o\&amp $\%{ }_{3}$ Bitm_seq_1=o\&amp $\% 3$ Bitm_seq_2=o\&amp $\% 3$ Bcompany_ $\mathrm{cd}=\&$ amp $\%{ }_{3}$ Bcompany_nm $=$.

—. 2020f. 'Press Release: ROK Leads Launch of Group of Friends for Solidarity and Inclusion with Global Citizenship Education.' Republic of Korea: Ministry of Foreign Affairs. Accessed 25 October 2020. http://www.mofa.go.kr/eng/ $\mathrm{brd} / \mathrm{m} \_5676 /$ view.do?seq=321101. 
- 2020g. 'Press Release: ROK Leads Launch of Support Group for Global Infectious Disease Response (G4IDR).' Republic of Korea: Ministry of Foreign Affairs. Accessed 25 October 2020. https://www.mofa.go.kr/eng/brd/m_5676/view. do?seq=321097.

- 2020h. 'Press Release: ROK Leads Launch of UN Group of Friends of Solidarity for Global Health Security.' Republic of Korea: Ministry of Foreign Affairs. Accessed 25 October 2020. http://www.mofa.go.kr/eng/brd/m_5676/view. do?seq=321088.

Ministry of Health and Welfare (MOHW). 2020. 'Bodojaryo: Kim Gang Rip Bogeonbokjibu Chagwan, Segyebogungigu Jiphaengisa Jimyeong [Press Release: Vice Minister Kim Appointed as the Member of the WHO Executive Board].' Republic of Korea: Ministry of Health and Welfare. Accessed 25 October 2020. http://www.mohw.go.kr/react/al/salo3orvw. jsp?PAR_MENU_ID=04\&MENU_ID=0403\&CONT_SEQ=354611.

OECD. 2021. 'OECD CRS Database.' Accessed 11 January 2021. https://stats.oecd.org/ Sommer, Bob, and John R. Maycroft. 2008. 'Influencing Public Policy: An Analysis of Published Op-Eds by Academics.' Politics and Policy vol. 36, no. 4: 586-613.

The Economist. 2021. 'The COVID-19 Health Funding Tracker.' Accessed 11 January 2021. https://covidfunding.eiu.com/.

Trudeau, Justin, Sahle-Work Zewde, Jae-in Moon, Jacinda Ardern, Cyril Ramaphosa, Pedro Sánchez Pérez-Castejón, Stefan Lofven, and Elyes Fakhfakh. 2020. 'The International Community Must Guarantee Equal Global Access to a Covid-19 Vaccine.' The Washington Post, 16 July. Accessed 5 November 2020. https://www. washingtonpost.com/opinions/2020/07/15/international-community-mustguarantee-equal-global-access-covid-19-vaccine/.

World Health Organization (WHO). 2020a. 'Advice on the Use of Masks in the Community, during Home Care, and in Health Care Settings in the Context of COVID-19: Interim Guidance (19 March 2020).'

- 2020b. 'Coronavirus Global Response: Access to COVID-19 Tools-Accelerator Facilitation Council Holds Inaugural Meeting.' 10 September. Accessed 25 October 2020. https://www.who.int/news/item/10-09-2020-coronavirusglobal-response-access-to-covid-19-tools-accelerator-facilitation-council-holdsinaugural-meeting.

Yamey, Gavin, Marco Schäferhoff, Richard Hatchett, Muhammad Pate, Feng Zhao, and Kaci Kennedy McDade. 2020. 'Ensuring Global Access to COVID-19 Vaccines.' The Lancet vol. 395, no. 10234: 1405-1406.

Yonhap. 2020. 'Countries Issue Joint Statement Calling for Fair Distribution of Coronavirus Vaccines.' 21 September. Accessed on 25 October 2020. https:// en.yna.co.kr/view/AEN20200921010300325. 


\section{About the Authors}

Eun Mee KIM is the seventeenth President of Ewha Womans University. She is Professor in the Graduate School of International Studies, Director of the Ewha Global Health Institute for Girls and Women, and former Dean of the Graduate School of International Studies, and former Director of the Institute for Development and Human Security at Ewha Womans University. She was appointed by the UN Secretary General in December 2016 to serve as one of the fifteen Independent Group of Scientists working on the Global Sustainable Development Report 2019, which was presented to the UN Secretary General and heads of member states at the UN General Assembly in September 2019 .

Jisun SONG is Assistant Professor at the Institute of Foreign Affairs and National Security of the Korea National Diplomatic Academy. Previously, she worked as Research Professor at the Institute for Development and Human Security of the Ewha Womans University. She received her PhD in International Studies from Ewha Womans University. Her research and publications focuses on international development cooperation, aid effectiveness, foreign aid modalities, global health security, and gender and development. 



\title{
11 State-Society Relations as Cooperative Partnership and the COVID-19 Response in Vietnam
}

\author{
Mirjam LE and Franziska NICOLAISEN
}

\begin{abstract}
The Vietnamese government used symbolic nationalism to gain public support for its containment strategies over the course of the COVID-19 pandemic. This included a transparent communication strategy that portrayed citizens as part of the solution. This chapter argues that this approach is rooted in an emerging cooperative partnership between state and society in Vietnam, and that these comprehensive governance strategies have strengthened trust in the Communist Party of Vietnam, bolstering its legitimacy. However, this approach has also led to questions about the government's lack of transparency during past crises. If the public feels that the government is not protecting national interests against others, particularly China, this will reduce the gains in legitimacy made during the COVID-19 pandemic.
\end{abstract}

Keywords: state-society relations, Vietnam, public health, COVID-19, political legitimacy, symbolic nationalism

\section{Introduction}

Vietnam has been relatively successful in handling the COVID-19 crisis, with a low number of deaths (35 deaths until 7 March 2021) and a low number of cases (2512 cases in a country of 97 million people [World Health Organization 2021, 1]). Regional experts and health officials have praised the Vietnamese response to the COVID-19 pandemic as exemplary (Dabla-Norris, Gulde-Wolf,

\footnotetext{
Van der Veere, Anoma P., Florian Schneider, and Catherine Yuk-ping Lo (eds), Public Health in Asia during the COVID-19 Pandemic: Global Health Governance, Migrant Labour, and International Health Crises. Amsterdam, Amsterdam University Press 2022 DOI: 10.5117/9789463720977_CH11
} 
and Painchaud 2020). This chapter gives an overview of the underlying factors producing this effective response: timeliness in implementation of policies, experience with previous infectious diseases, transparency, and commitment. It analyses the strategies which emerged from these factors, with a focus on transparent communication, a broad social mobilization based on national identity, and the central involvement of the Vietnamese labour movement. The relative success of these strategies provided legitimacy for the Vietnamese state.

This chapter argues that the strategies employed by the government are representative of an emerging cooperative partnership between state and society in Vietnam. This has allowed for the level of transparency and sense of accountability that have been essential for Vietnam's communication and mobilization strategy during the pandemic. However, some of the contradictions inherent in these strategies might threaten the political leverage gained.

\section{Health Governance in Vietnam and the COVID-19 Pandemic}

Several factors have contributed to Vietnam's success in combating the coronavirus (Bui et al. 2020). The first factor leading to this success has been the Vietnamese government's timeliness in taking action. The Vietnamese government often took action before the World Health Organization (WHO) issued related advice (Bui 2020). The virus was first detected in Vietnam on 23 January 2020 (Murray and Pham 2020). Then on 28 January the government developed an action plan based on a pandemic scenario (Bui 2020). On 1 February, while case numbers were in the single digits, the government cancelled all flights from China and stopped issuing tourist visas to citizens of affected countries (Murray and Pham 2020). Vietnamese schools were closed and did not reopen after the Lunar New Year holiday but were ordered to extend their holidays on a week-by-week basis (Murray and Pham 2020). Vietnam completely closed its borders to foreign nationals on $22 \mathrm{March}$ (Elegant 2020).

In July 2020 the virus emerged again in the city of Danang following 99 days without confirmed community transmission. After the detection of two new cases, the authorities immediately imposed a lockdown in Danang, implementing social distancing measures and preparing to evacuate 80,000 domestic tourists (Peer 2020). These tourists were ordered to quarantine for fourteen days after returning home (Elegant 2020).

According to Murry and Pham (2020), the Vietnamese Communist Party implemented this rapid response to COVID-19 because it understands the 
inner workings of policy- and decision-making in Beijing and distrusts official Chinese communication. Because of this distrust, the Vietnamese government sought its own information through informal channels to understand the situation in Wuhan (Thayer 2020; Stubbs and Satter 2020).

A second factor in Vietnam's effective response to the COVID-19 pandemic has been its previous experience of handling infectious diseases, including the SARS pandemic in 2003, as well as other infectious diseases such as dengue fever (Bui 2020). Measures that were applied in 2020 had already proven successful earlier (Bui 2020). Since the SARS pandemic in 2003, Vietnam has expanded its capacity to control emerging infectious diseases (Le S.M. 2020). This meant that, when confronted with the COVID-19 pandemic at the start of 2020, the authorities immediately had effective mass testing, contact tracing, and quarantine measures available (Duong, Le, and Bui 2000).

A third factor in Vietnam's successful handling of the COVID-19 pandemic has been the transparency of government actions. Close and effective coordination and communication among different levels of government ensured that information given out to the public was accurate throughout the initial stages of the outbreak (Bui 2020). This affected public perceptions of how serious the disease was. The way in which the government raised awareness of COVID-19 early on was essential to ensure public compliance and mobilization (Bui et al. 2020, 2). Vietnam suffers from limited resources and fragile health infrastructure. The healthcare system could therefore have been overburdened if a high number of people had been infected. This meant that, particularly during the early stages of the COVID-19 crisis, there was an urgent need for the government to prioritize containment of the virus.

Vietnam's response has been described as aggressive and rooted in authoritarianism (Bui 2020). Nevertheless, its success in minimizing community spread and infection numbers also shows that this level of commitment has been effective in containing the pandemic (Duong, Le, and Bui 2000). Policies have often been harsh in implementation. The government mobilized the military and retired medical personnel to assist the implementation of its response strategy. The authorities issued strict quarantine measures that relied on military supervision. The Vietnamese leadership deemed the use of the military as essential for 'coordinating food, transport and accommodation required to quarantine thousands of people' (Bui 2020). The government also mobilized all sectors of the economy to produce equipment to help fight the virus. These measures have been justified as a means for wiping out the virus entirely (Peer 2020). 


\section{Strategies of Grassroots Mobilization in Vietnam}

\section{Communication Strategies}

The Vietnamese government has proven creative and media savvy in communicating with the public. It framed the fight against the virus using the 'language of war' (Bui 2020). In a clear reference to the 1968 Tet offensive that took place during the war between Vietnam and the US (1955-1975), ${ }^{1}$ Prime Minister Nguyen Xuan Phuc called the fight against COVID-19 the 'Spring General Offensive of 2020' (Murray and Pham 2020). This wartime language was used with the aim of mobilizing all of Vietnam's citizens as active participants against COVID-19 (Truong 2020b).

Information has been communicated through an array of channels, including the use of social media platforms, as well as messages sent directly to people's mobile phones. Newspapers reported daily case numbers, COVID-19 deaths (or the absence of deaths until July), and the number of Vietnamese repatriated from abroad (La et al. 2020, 12-14; Truong 2020b). When the virus re-emerged in the city of Danang in late July, the state again used the same methods of communication to prevent a public backlash against the strict containment measures. The Vietnamese state presented itself as a competent and caring actor that was promoting the common good. This has helped drive up support for the Vietnamese government's message: that the people of Vietnam should feel national pride in the successful pandemic response, and that success has been a result of cooperative efforts. A study from 30 March 2020 showed that $62 \%$ of the survey respondents saw the government's response as adequate, which was the highest percentage in 45 countries assessed. Only $13 \%$ of respondents thought that the Vietnamese government should do more and $12 \%$ thought that the government had overreacted (Dölitzsch 2020). International recognition of Vietnam, as a model for low-income countries in how to handle the pandemic, has further strengthened this message (Dabla-Norris, Gulde-Wolf, and Painchaud 2020).

The production of coronavirus messaging also involved the creative sector. In late February, the National Institute of Occupational Safety and Health funded and released a music video by the singer Khac Hun on YouTube called 'Jealous Coronavirus' (Ghen Cô Vy) that promoted basic preventive measures

1 We are aware that the term used in academic literature is 'Vietnam War'. However, the use of this term reflects a US-centric narrative. This paper is written from a Vietnamese perspective, and in the spirit of decolonising academia we decided to use the above description and will continue to use 'Vietnam-US War'. 
(Saigoneer 2020). The video portrayed the coronavirus as a common enemy against which the Vietnamese nation and every citizen should mobilize. This video was very popular, including outside of Vietnam. It was spread by global media outlets such as $\mathrm{HBO}$ and inspired a viral TikTok dance trend that further engaged the public (La et al. 2020, 12-14; Last Week Tonight with John Oliver 2020).

While this music video used cartoon animation, other imagery in the public sphere primarily used a form of symbolic nationalism. The use of historic imagery reminiscent of war propaganda on billboards nationwide is a staple of political communication in Vietnam, reminding the public of a shared history and identity (Humphrey 2020; Kirubakaran 2020; Nguyen M. 2020).

Due to this direct, open, and clear messaging strategy from the state, the pandemic has been successfully framed as a national emergency which demands sacrifices and the participation of every citizen. This strategy has stressed national unity and the role of each individual, and it has thus framed every citizen as part of the crisis management. In this way the COVID-19 response has essentially been a campaign of national pride in accordance with a longer tradition of the 'war against imperialism' that extends back to the Vietnam-US War as well as the fight against French colonial rule (Truong 202ob; Hartley 2021, 159). War metaphors are a common rhetorical tool in public discourse. They relate to an emotional experience and an adversarial threat which needs to be defeated as a common enemy. These metaphors are easy to understand and can be very useful in mobilization. However, they might create adversarial relations and reduce moral complexities (Flusberg et al. 2018, 25). The war metaphors in the Vietnamese public discourse on COVID-19 relate back to the Vietnam-US War, and the sacrifices demanded from Vietnamese citizens during that time. It establishes an emotional continuity. The focus is on the need for sacrifices and behavioural changes from everyone as well as the acceptance of state control to counter the threat. This was successful in mobilizing large parts of the population to follow rules and accept quarantine measures and limits to free movement. However, it might also paint all those who are less willing to make sacrifices, including those who are infected, as threatening the success. It might also push a social narrative in which neighbours police each other.

\section{Social Participation and Communication}

The Vietnamese government portrayed every citizen as an integral part of the national solution to the COVID-19 pandemic. Its open manner of 
communication has helped increase the willingness of the public to comply with regulations, and there has been a high acceptance of measures such as the quarantining of people and contact tracing (La et al. 2020, 18-20; Tran, DiGregorio, and Nixon 2020). In addition, masks were already widely used in urban spaces because of concerns about air quality (Onishi 2020; Duong M.C. 2020). As a result, instructions to wear masks to help prevent the spread of COVID-19 have met with little resistance (Le S.M. 2020). The government published lists of locations with contact tracing dates, urging anyone who visited these spots in the given timeframe to report to health officials, and social pressure reportedly also increased the willingness of the public to be named as contacts by family members or friends (Bui 2020; Tran, DiGregorio, and Nixon 2020). For example, in a much-reported case in May 2020, a man was reprimanded by his aunt after illegally crossing the border from Cambodia into Tay Ninh province to visit his family. Thereupon, he presented himself to the nearest police station for quarantining (Le N. 2020).

The Vietnamese public's solidarity in tackling the pandemic can also be seen in several grassroots initiatives. In one widely publicized initiative, a Ho Chi Minh City entrepreneur set up rice ATMs to dispense rice to low-income families. These ATMs found official support and can now be found nationwide (Duong and Yen 2020). This cooperation between state and citizens for the public interest was central in official communication, as it exemplified the official message of citizens contributing to the state's efforts (La et al. 2020). The enforcement of quarantine measures has also been widely supported by the public. Social media, newspapers, photos, and paintings, have presented positive narratives about quarantine experiences, supporting the government's strategy (Nhat Minh 2020; MacDonald 2020; Ng 2020; Snell 2020; La et al. 2020, 12-14). For example, Gavin Wheeldon, a British citizen living in Vietnam, shared his positive experience of being quarantined in a government facility on Facebook and wrote an online article (Wheeldon 2020). His story was then picked up by the Vietnamese press and he was interviewed for a documentary on national television (Talk VietNam 2020). This episode showcases how the Vietnamese government has actively presented a positive narrative regarding its response in its communication to the public during the pandemic.

However, social pressure and uncertainties during the pandemic can also have significant side-effects. In early March, a social media influencer and daughter of a wealthy Vietnamese family in Hanoi returned from traveling in Europe and subsequently infected numerous people. The government locked down her neighbourhood, shared private information, and invited the press to a live-stream meeting concerning the woman's health. The 
government used the case to make an example of her. After people figured out her identity, she was harassed on social media, particularly on Instagram. People circulated rumours about her being the cause of a new wave of infections, as the first large outbreak in Vietnam in almost a month directly followed her arrival (Max 2020). The government has leveraged this case to emphasize a moral responsibility towards the community, and those defying this morality are perceived by the public in a negative light (La et al. 2020, 12-14). Referring back to the martial language used by the administration, the framing of the pandemic using wartime language thus turns the COVID-19 pandemic into an existential struggle, which can, in turn, heighten anxieties and inspire self-righteous bullying and mobbing (Flusberg et al. 2018, 21-22).

However, public support went beyond observing preventive measures and moral responsibility, as demonstrated by the public interest in the case of a British pilot working for Vietnam Airlines. For months, national media reported on his critical condition almost daily, as many feared he would be the first COVID-19 death in Vietnam. Calls by the local administration for lung donors were answered with public support. The pilot's recovery has been one of the main focus points in the positive framing of the Vietnamese fight against COVID-19. The media attention given here shows the level of community solidarity and moral responsibility the government is trying to convey to the public in its communication during the pandemic. To uphold public morale the government aimed to maintain zero COVID-19 deaths at that time (Vietnam Insider 2020).

However, this particular case also showcases a level of accountability towards the international community (Barnes and Bui 2020). In this narrative, Vietnam takes up the role of saving a European national from death, as though they were a Vietnamese citizen (Truong 202ob). This success story was, in turn, contrasted in the media with the relative failure of many Western countries to effectively respond to the pandemic (Truong 2020b). Set against these Western failings, the effective and level-minded response at home is then emphasized as a point of national pride.

\section{Labour Activism}

Beyond this broad social mobilization, Vietnam was also the arena for narrower and more specific social activism advancing the pandemic response, particularly in the field of labour rights and protections. Generally, the Vietnam General Confederation of Labour (VGCL), Vietnam's workers' union, lobbies for national-level changes to improve working conditions. Workers participate in self-organized struggles, so-called wildcat strike 
actions, ${ }^{2}$ to deal with local issues of wages and working conditions. This creates a dual structure that has frequently proven to be effective (Däubler 2018, 153). Local government officials often support local worker strikes and help negotiate solutions (Sui and Chan 2015; Kerkvliet 2011; Buckley 2020). During the COVID-19 pandemic, labour activists have been demanding accountability from the government and the corporate sector in accordance with the idea of this cooperative partnership.

This well-established system has helped mitigate the economic and health risks for Vietnamese workers. The VGCL has followed an educative approach, disseminating information on prevention and distributing masks and hand sanitizers. It has also used a policy approach to lobby the government to find solutions to lessen the economic pressure on workers. At the time of writing, the global economy remained in a recession, and Vietnam's GDP growth was lower than previously predicted, making this kind of economic support increasingly important (Buckley 2020).

Turning specifically to the issue of labour activism, workers held wildcat strikes to demand personal protective equipment (PPE) and other measures to prevent the spread of the virus in factories. Local union officials organized information events with medical experts at companies. These actions by workers have forced companies to implement at least some safety measures at the local level (Buckley 2020). For example, in the case of the Pinetree garment factory, workers stayed home at the end of January 2020 after two employees fainted due to lack of oxygen. Although they turned out to not have been infected with COVID-19, the workers in the factory demanded that precautionary health measures be implemented in accordance with existing regulations. The company agreed to provide free masks, temperature checks, and disinfectant to over a thousand employees (LDO 2020b; Buckley 2020).

Wildcat strikes have also helped prevent companies from passing the economic costs of COVID-19 onto their workers. Many companies, negatively impacted by the economic downturn, have attempted to reduce their wage burden by refusing to pay their workers or by putting them on furlough. Strikes carried out with the support of local state officials have helped to ensure that these companies continue to pay employees (Buckley 2020). For example, the Seething shoe factory in Haiphong announced at the end of May 2020 that it would not pay outstanding bonuses, overtime payments,

2 As Pham (2017) states: 'a legal strike has to fulfil two criteria: firstly, it can only take place after a procedure stipulated by the law which rules out rights-based strikes; and secondly, it has to be led by a trade union. However, all strike incidents in Vietnam appear to be spontaneous and unorganized, and thus are illegal and referred to as wildcat strikes.' 
and social insurance contributions due to a lack of money. Consequently, on 22 and 23 May 2020, a thousand workers went on strike. The company then stated that they would pay the money in instalments but would also put a number of workers on leave without pay. This led to more protests on 25 May, leading to an intervention by authorities who declared that the company was breaking legal regulations and would have to continue paying wages to its workers (LDO 2020a; Buckley 2020).

However, this was not a national standard. In other factories, workers still lost their jobs, either temporarily or permanently. These newly unemployed are now dependent on their social networks and on state assistance for financial support (Buckley 2020). Despite the limits of labour activism, local workers and the VGCL have played an important role in helping confront the pandemic at different levels, both for local implementation and enforcement as well as for policy making (Buckley 2020). Once again, cooperative partnership strategies have been adopted, this time by workers demanding accountability. In fact, by supporting these workers, local state institutions seem to have gained a higher level of public support during the pandemic (Hartley 2021, 160-161).

\section{State Legitimacy and Emerging Contradictions}

The Vietnamese government has successfully embedded COVID-19 in a historical narrative that depicts the 'fight' of the Vietnamese people against external threats. This creates a sense of historic continuity and can potentially provide further legitimacy for the current political system. Legitimacy here can be understood as a 'quality of a rule which derives from a perception on the part of those to whom it is addressed that it has come into being in accordance with right process' (Franck 1988, 706). Legitimacy leads to the acceptance of government rule as rightful, in this case based on merit, and thus fosters public support. In the narrative about COVID-19 that the government has presented, Vietnam has not only successfully managed the pandemic without outside help, but has painted itself as exemplary, offering help to others. Its effective and prudent response has been made into a focal point for national pride. At the same time, the COVID-19 response has revealed a number of internal contradictions.

\section{Nationalism}

The Vietnamese government's narrative has focused on COVID-19 entering from abroad. Due to the complicated historic relations with China (Strangio 
2020b, 64-84), the Vietnamese public has been particularly critical of the government's response towards China and Chinese nationals. Border-crossings were seen in public discourse as responsible for COVID-19 re-entering Vietnam several times, which led to public outrage (La et al. 2020, 12-14; Bohane 2020). In February, factory workers based near the border with China felt that Chinese nationals returning from their hometowns after the Chinese New Year celebrations were not quarantining and being tested properly. Workers went on strike to protest this perceived lack of enforcement of COVID-19 regulations by local officials (Buckley 2020). When the number of infections rose sharply in late July, the public was once again quick to blame China. Some official sources echoed the public in blaming Chinese migrants for the rising infections, while other sources did not (Elegant 2020). However, if the Vietnamese public feels that the government is not effectively protecting Vietnamese interests against China, this will reduce the gains in legitimacy that the Vietnamese government has made during the COVID-19 pandemic.

\section{Participation and Transparency}

The government's handling of the COVID-19 pandemic has increased public cooperation by including citizens in its efforts. However, public space to challenge the state has not increased, and it has maintained an iron grip on public discourse. In recent years, the Vietnamese government has been using repressive means to stabilize the country (Kerkvliet 2014). During the pandemic, this crackdown on dissidents has continued (HRW 2020; Strangio 2020a). There was a particularly intensive crackdown as the party prepared for the $13^{\text {th }}$ National Congress of the Communist Party of Vietnam in January 2021 (The Straits Times 2021).

Vietnam's perceived success in containing the virus has proven the capacity and competency of the Party to effectively address public health crises. However, it also produces questions about the government's lack of transparency during past crises (Truong 2020a). Therefore, how the government deals with political dissent raises questions about its long-term commitment to more open and transparent state communication, which might eventually undermine state legitimacy.

\section{Economic Question Marks}

While the Vietnamese government has so far been able to contain the COVID-19 pandemic, its economic recovery is being affected by the situation among its main trading partners such as the United States, Japan, and China 
(World Bank 2020, 23). A major recession has so far been prevented, and at the end of 2020 the government still maintained that Vietnam's GDP had grown by $2.91 \%$ that year (Nguyen P. 2020). The State Bank of Vietnam expected a full recovery of the economy in 2021, and it predicted a GDP growth of $6.5 \%$ (Anh Phuong 2020). However, unemployment and underemployment remain severe problems (Nguyen et al. 2020). By September 2020, 31.8 million people, or more than a third of the Vietnamese population, had been negatively affected by the pandemic (GSO 2020). In order to support its citizens, the Vietnamese government announced a US\$2.6 billion support package (Buckley 2020). At the time of writing, it still remained to be seen how this support package would be used.

Economic success and growing prosperity are important pillars of the Vietnamese government's merit-based legitimacy. A long-term economic downturn might have political repercussions for the party-state. If Vietnam experiences economic uncertainties in the wake of the health crisis, this might undo the gains in political legitimacy the government has achieved as a result of its effective response to COVID-19.

\section{Conclusion}

After managing the first year of COVID-19 in the country, Vietnam now faces an uncertain future. ${ }^{3}$ Domestically, the general consensus is that the low number of cases and fast return to normal everyday life have vindicated Vietnam's strategy. This chapter has argued that transparent communication and social mobilization have been the cornerstones of this successful strategy. The Vietnamese response to the pandemic has been based on a cooperative partnership formed between the state and its citizens (Le and Nicolaisen 2021).

Globally, Vietnam's strict national response has frequently been seen to be rooted in authoritarianism. However, the cooperative relationship between the government and the public has allowed the level of transparency necessary for Vietnam to communicate effectively during the pandemic while still creating a sense of accountability and responsiveness (Koh 2006). In the everyday political reality of Vietnam, these processes often produce localized conflicts (Le and Nicolaisen 2021). Nevertheless, during the recent COVID-19 pandemic, the Vietnamese state and society have been able to

3 Following April 2021, Vietnam faced another local outbreak with cases in 39 provinces. By 9 June 2021 this outbreak was responsible for 6.328 cases and 20 deaths. Vietnam is also lagging in its vaccination efforts. 
transcend these conflicts by emphasizing a shared Vietnamese struggle, identity, and shared responsibility - all themes that the government utilized in its communication to induce cooperation among citizens.

Once the pandemic ends, a sudden reversal in the transparency of this communication might lead to a loss of the legitimacy built during the pandemic. Economic uncertainties in the coming months might also threaten the gains made in political legitimacy. Additionally, the party-state will need to balance its relations with China with its nationalist narrative. Therefore, to keep the positive momentum going, the Vietnamese government needs to reduce the risk of another local outbreak, find ways to assist citizens suffering economically, and balance the public demand for transparency and national strength with its desire for self-preservation.

\section{References}

Anh, Phuong. 2020. 'Vietnam GDP Growth to be Among World's Highest in 2020: IMF.' VNExpress, 19 November. Accessed 10 February 2021. https://e.vnexpress. net/news/business/economy/vietnam-gdp-growth-to-be-among-world-s-highestin-2020-imf-4194065.html.

Barnes, Oliver and Bui Thu. 2020. 'Patient 91: How Vietnam Saved a British Pilot and Kept a Clean Covid-19 Sheet.' BBC News, 26 June. Accessed 10 February 2021. https://www.bbc.com/news/world-asia-531960og.

Bohane, Hugh. 2020. 'Inside the Epicentre of Vietnam's Covid-19 Resurgence.' The Diplomat, 5 August. Accessed 10 February 2021. https://thediplomat.com/2020/08/ inside-the-epicenter-of-vietnams-Covid-19-resurgence/.

Buckley, Joe. 2020. 'The Role of Labour Activism in Vietnam's Coronavirus Success.' Equal Times, 2 July. Accessed 10 February 2021. https://www.equaltimes.org/ the-role-of-labour-activism-in?lang=en\#.X41j7-1CRPY.

Bui Thi Thu Ha, La Ngoc Quang, Tolib Mirzoev, Nguyen Trong Tai, Pham Quang Thai, Phung Cong Dinh. 2020. 'Combating the Covid-19 Epidemic: Experiences from Vietnam.' International Journal of Environmental Research and Public Health vol. 17, no. 9: 3125. https://doi.org/10.339o/ijerph17093125.

Bui, Trang. 2020. 'Aggressive Testing and Pop Songs: How Vietnam Contained the Coronavirus.' The Guardian, 1 May. Accessed 10 February 2021. https://www.theguardian.com/commentisfree/2020/may/o1/testing-vietnam-contained-coronavirus.

Dabla-Norris, Era, Anne-Marie Gulde-Wolf and Francois Painchaud. 2020. 'Vietnam's Success in Containing COVID-19 Offers Roadmap for Other Developing Countries.' IMF Asia and Pacific Department, 29 June. Accessed 10 February 2021. https:/www.imf.org/en/News/Articles/2020/o6/29/ 
nao62920-vietnams-success-in-containing-covid19-offers-roadmap-for-otherdeveloping-countries.

Däubler, Wolfgang. 2018. 'Trade Union Pluralism in Vietnam - Coping with Informal Associations.' In Trade Unions in Transition, Rudolf Traub-Merz and Tim Pringle (eds.): 149-162. Berlin: Friedrich-Ebert-Stiftung.

Dölitzsch, Christoph. 2020. 'Global Study about COVID-19: Dalia Assesses How the World Ranks their Governments' Responses to the Pandemic.' Dalia Research, 30 March. Accessed 22 March 2021. https://daliaresearch.com/blog/ dalia-assesses-how-the-world-ranks-their-governments-response-to-covid-19/

Duong, Minh Cuong. 2020. 'Mass Masking and Vietnam's COVID-19 Success.' East Asia Forum, 23 October. Accessed 10 February 2021. https://www.eastasiaforum. org/2020/10/23/mass-masking-and-vietnams-covid-19-success/.

Duong, Minh Duc, Le Vui Thi and Bui Thi Thu Ha. 2020. 'Controlling the COVID-19 Pandemic in Vietnam: Lessons from a Limited Resource Country.' Asia Pacific Journal of Public Health vol. 32, no. 4: 161-162. https://doi. org/10.1177\%2F1010539520927290.

Duong, Yen. 2020. 'Rice ATM' Feeds Vietnam's Poor Amid Virus Lockdown.' Reuters, 13 April. Accessed 10 February 2021. https://uk.reuters.com/article/ uk-health-coronavirus-vietnam-riceatm/rice-atm-feeds-vietnams-poor-amidvirus-lockdown-idUKKCN21VoGP.

Elegant, NaomiXu. 2020. 'Vietnam had One of the World's Best COVID Responses. Now that Success is in Peril.' Fortune, 27 July. Accessed 10 February 2021. https://fortune. com/2020/07/27/vietnam-Covid-coronavirus-response-outbreak-second-wave/.

Flusberg, Stephen J., Teenie Matlock and Paul H. Thibodeau. 2018. 'War Metaphors in Public Discourse.' Metaphor and Symbol vol. 33, no. 1: 1-18.

Franck, Thomas. 1988. 'Legitimacy in the International System.' The American Journal of International Law vol. 82, no. 4 (October 1988): 705-759.

General Statistics Office of Vietnam (GSO). 2020. 'Report on the Impact of Covid-19 on Labour and Employment of the Third Quarter of 2020.' Government of Socialist Republic of Vietnam.

Hartley, Kris, Sarah Bales and Azad Singh Bali. 2021. 'COVID-19 Response in a Unitary State: Emerging Lessons from Vietnam.' Policy Design and Practice vol. 4, no. 1: 15 .

Human Rights Watch (HRW). 2020. 'Vietnam: Crackdown on Peaceful Dissent Intensifies.' 19 June. Accessed 10 February 2021. https://www.hrw.org/news/2020/06/19/ vietnam-crackdown-peaceful-dissent-intensifies.

Humphrey, Chris. 2020. “In a War, We Draw': Vietnam's Artists Join Fight Against Covid-19.' The Guardian, 9 April. Accessed 10 February 2021. https://www. theguardian.com/global-development/2020/apr/og/in-a-war-we-draw-vietnamsartists-join-fight-against-covid-19. 
Kerkvliet, Benedict. 2014. 'Government Repression and Toleration of Dissidents in Contemporary Vietnam.' In Politics in Contemporary Vietnam: Party, State and Authority Relations, Jonathan London (ed.): 100-134. Houndmills, UK and New York, Palgrave/MacMillan.

- 2011. 'Workers' Protests in Contemporary Vietnam.' Journal of Vietnamese Studies vol. 5 no. 1: 162-204. https://doi.org/10.1525/vs.2010.5.1.162.

Kirubakaran, Pragadish. 2020 'From Propaganda Posters to War Rhetoric, How Vietnam is Winning the War Against COVID-19.' Republic World, 19 May. Accessed 10 February 2021. https://www.republicworld.com/world-news/rest-of-the-world-news/ from-propaganda-posters-to-war-rhetoric-how-vietnam-fights-coronavirus.html. Koh, David. 2006. 'Wards of Hanoi.' ISEAS - Yusof Ishak Institute, Singapore.

La, Viet-Phuong, Thanh-Hang Pham, Manh-Toan Ho, Minh-Hoang Nguyen, KhanhLinh P. Nguyen, Thu-Trang Vuong, Hong-Kong T. Nguyen, Trung Tran, Quy Khuc, Manh-Tung Ho, and Quan-Hoang Vuong. 2020. 'Policy Response, Social Media and Science Journalism for the Sustainability of the Public Health System amid the COVID-19 Outbreak: The Vietnam Lessons.' Sustainability vol. 12: 2931. http:// dx.doi.org/10.339o/su12072931.

Lao Dong (LDO). 2020a. 'Hải Phòng: Doanh Nghiệp Nợ BHXH, Gần 1.00o Công Nhân Ngừng Việc. [Hai Phong: Company owes social insurance contribution, nearly 1,000 workers on strike].' Lao Dong, 23 May. Accessed 10 February 2021. https:// laodong.vn/cong-doan/hai-phong-doanh-nghiep-no-bhxh-gan-10oo-cong-nhanngung-viec-807398.ldo.

—. 2020b. 'Công Đoàn Vào Cuộc: Công Nhân Nhà Máy May Pinetree Tiếp Tục đi Làm. [Trade union gets involved: Pinetree garment factory workers continue to work].' Lao Dong, 31 March. Accessed 10 February 2021. https://laodong.vn/ cong-doan/cong-doan-vao-cuoc-cong-nhan-nha-may-may-pinetree-tiep-tucdi-lam-794687.ldo.

Last Week Tonight with John Oliver. 2020. 'Coronavirus.' Season 7, Episode 123. HBO, 1 March. https://www.hbo.com/last-week-tonight-with-john-oliver/2020/123episode-182.

Le, Mirjam, and Franziska Nicolaisen. 'Conflicted Citizenship in Vietnam - Between Grassroots Mobilization and State Repression.' In Vietnam at the Vanguard: New Perspectives across Time, Space, and Community, J. Gillen, L.C. Kelley, and L.H. Phan (eds.). Singapore: Springer.

Le, Nga. 2020. 'Four More Returnees Add to Vietnam's Covid-19 Tally.' VNexpress, 16 May. Accessed 10 February 2021. https://e.vnexpress.net/news/news/fourmore-returnees-add-to-vietnam-s-covid-19-tally-4100516.html.

Le, Phuong. 2020. 'Vietnamese London Resident is 32nd Covid-19 Patient.' VNexpress, 10 March. Accessed 10 February 2021. https://e.vnexpress.net/news/news/ vietnamese-london-resident-is-32nd-covid-19-patient-4067042.html. 
Le, Sang Minh. 2020. 'Containing the Coronavirus (COVID-19): Lessons from Vietnam.' World Bank Blog, 30 April. Accessed 10 February 2021. https://blogs. worldbank.org/health/containing-coronavirus-covid-19-lessons-vietnam.

MacDonald, Glen. 2020. 'Vietnam Quarantine Queens' Creative Coronavirus Cartoons.' Chao Hà Nội, 15 March. Accessed 10 February 2021. https://chaohanoi. com/2020/03/15/vietnam-quarantine-queens-coronavirus-cartoons/.

Max, D.T. 2020. 'The Public-Shaming Pandemic.' The New Yorker, 21 September. Accessed 10 February 2021. https://www.newyorker.com/magazine/2020/og/28/ the-public-shaming-pandemic.

Murray, Bennett and Bac Pham. 2020. 'Behind Vietnam's Covid-19 Response, Deep Distrust of China.' The Diplomat, 14 May. Accessed 10 February 2021. https://thediplomat.com/2020/05/behind-vietnams-Covid-19-response-deep-distrust-of-china/.

Ng, Josee. 2020. 'Vietnam's Quarantine Facilities are so Good, Netizens Say It's Their Dream Staycation.' The Smart Local, 20 March. Accessed 1o February 2021. https://thesmartlocal.com/vietnam/quarantine-facilities/.

Nguyen, Huong T.T., Tham T. Nguyen, Vu A.T. Dam, Long H. Nguyen, Giang T. Vu, Huong L.T. Nguyen, Hien T. Nguyen and Huong T. Le. 2020. 'COVID-19 Employment Crisis in Vietnam: Global Issue, National Solutions.' Frontiers in Public Health, Opinion Article, 4 December. https://doi.org/10.3389/fpubh.2020.590074.

Nguyen, Maya. 2020. 'Vietnam's War Against COVID19.' The Diplomat, 19 October. Accessed 10 February 2021. https://thediplomat.com/2020/10/ vietnams-war-against-covid-19/.

Nguyen, Phuong. 2020. 'Vietnam's 2020 Economic Growth Slips to 30-year Low Due to COVID-19.' Reuters, 27 December. Accessed 10 February 2021. https:// uk.reuters.com/article/us-vietnam-economy-gdp/vietnams-2020-economicgrowth-slips-to-30-year-low-due-to-covid-19-idUSKBN29107M.

Nguyen, Trang (Mae), and Edmund Malesky. 2020. 'Reopening Vietnam: How the Country's Improving Governance Helped it Weather the COVID-19 Pandemic.' Brookings, 20 May. Accessed 10 February 2021. https://www.brookings.edu/blog/ order-from-chaos/2020/05/20/reopening-vietnam-how-the-countrys-improvinggovernance-helped-it-weather-the-covid-19-pandemic/.

Nhat, Minh. 2020. 'Paintings about Life in Quarantine Area Inspire Vietnamese People.' Hà Nội Times, 19 April. Accessed 10 February 2021. http://hanoitimes.vn/ paintings-about-life-in-quarantine-area-inspire-vietnamese-people-311802.html. Onishi, Tomoya. 2020. 'Pollution Masks Help Vietnam Ward Off Coronavirus.' Nikkei Asia, 9 October. Accessed 10 February 2021. https://asia.nikkei.com/Spotlight/ Coronavirus/Pollution-masks-help-Vietnam-ward-off-coronavirus.

Peer, Mathias. 2020. 'Auslöschen statt Abflachen.' Die Zeit, 7 August. Accessed 10 February 2021. https://www.zeit.de/politik/ausland/2020-08/ coronavirus-vietnam-zweite-welle-lockdown. 
Pham, Thi Thu Lan. 2017. 'Why Always Wildcat Strikes in Vietnam?' Global Labour Column, University of the Witwatersrand, Johannesburg, no. 290, October. Accessed 10 February 2021. http://www.global-labour-university.org/fileadmin/ GLU_Column/papers/no_29o_Pham_Thi_Thu.pdf.

Saigoneer. 2020. 'This V-Pop Song about Coronavirus is Going Viral.' Saigoneer, 26 February. Accessed 10 February 2021. https://saigoneer.com/ saigon-music-art/18387-video-this-v-pop-song-about-coronavirus-is-going-viral.

Snell, Govi. 2020. 'Saigoneer Bookshelf: Portraits of Frontline Workers from Inside Quarantine.' Saigoneer, 19 August. Accessed 10 February 2021. https://saigoneer. com/vietnam-literature/19116-saigoneer-bookshelf-portraits-of-frontlineworkers-from-inside-quarantine.

Strangio, Sebastian. 2020a. 'Scorched Earth': Vietnam Arrests Leading Dissident Activist and Blogger.' The Diplomat, 8 October. Accessed 10 February 2021. https://thediplomat.com/2020/10/scorched-earth-vietnam-arrests-leadingdissident-activist-and-blogger/.

- 202ob. In the Dragon's Shadow. New Haven/London: Yale University Press.

Stubbs, Jack and Raphael Satter. 2020. 'Vietnam-linked Hackers Targeted Chinese Government over Coronavirus Response: Researchers.' Reuters, 22 April. Accessed 10 February 2021. https:/www.reuters.com/article/ us-health-coronavirus-cyber-vietnam-idUSKCN2241C8.

Sui, Kaxton and Anita Chan. 2015. 'Strike Wave in Vietnam, 2006-2011.' Journal of Contemporary Asia vol. 45, no.1: 71-9. https://doi.org/10.1080/00472336.2014.903290. Talk VietNam. 2020. 'Talk VietNam: Cảm Ơn Nhé, Việt Nam! (Thank you, Vietnam),' $V T V, 5$ April. Accessed 10 February 2021. https://vtv.vn/video/talk-vietnam-camon-nhe-viet-nam-431125.htm.

Thayer, Carl. 2020. 'Did Vietnamese Hackers Target the Chinese Government to Get Information on COVID-19?' The Diplomat, 2 May. Accessed 10 February 2021. https://thediplomat.com/2020/05/did-vietnamese-hackers-target-the-chinesegovernment-to-get-information-on-covid-19/.

The Straits Times. 2021 'Vietnam Steps up 'Chilling' Crackdown on Dissent Ahead of Key Communist Party congress.' The Straits Times, 19 January. Accessed 10 February 2021. https://www.straitstimes.com/asia/se-asia/vietnam-stepsup-chilling-crackdown-on-dissent-ahead-of-key-communist-party-congress.

Tran Chung Chau, Michael DiGregorio and Nicola Nixon. 2020. 'Vietnam: A Covid-19 Success Story.' The Asia Foundation, 27 May. Accessed 10 February 2021. https:// asiafoundation.org/2020/05/27/vietnam-a-covid-19-success-story/.

Truong, Mai. 2020a. 'Vietnam's Covid-19 Success is a Double-Edged Sword for the Communist Party.' The Diplomat, 6 August. Accessed 10 February 2021. https://thediplomat.com/2020/o8/ vietnams-Covid-19-success-is-a-double-edged-sword-for-the-communist-party. 
- 202ob. 'Vietnam's Communist Party Finds a Silver Lining in COVID-19.' The Diplomat, 28 March. Accessed 10 February 2021. https://thediplomat.com/2020/03/ vietnams-communist-party-finds-a-silver-lining-in-covid-19/.

Vietnam Express. 2021. 'Số liệu Covid-19 tại Việt Nam [COVID-19 data in Vietnam].' Vietnam Express, 9 June. Accessed 9 June 2021. https://vnexpress.net/covid-19/ covid-19-viet-nam.

Vietnam Insider. 2020. 'Why Many Vietnamese Volunteered to Donate Part of Their Lungs to the British Covid-19 Patient?' Vietnam Insider, 16 May. Accessed 10 February 2021. https://vietnaminsider.vn/why-many-vietnamese-volunteeredto-donate-part-of-their-lungs-to-the-british-covid-19-patient/.

Vinh Tho. 2021. 'Vietnam's Corona Virus Fund Receives of \$40 Million.' Tuoi Tre News, 6 June. Accessed 9 June 2021. https://uoitrenews.vn/news/society/202106o6/ vietnams-coronavirus-vaccine-fund-receives-over-40-million/61342.html.

Wheeldon, Gavin. 2020. 'Tales of the Pandemic: Life Inside a Vietnamese Government Quarantine.' Southeast Asia Globe, 16 March. Accessed 10 February 2021. https://southeastasiaglobe.com/ coronavirus-life-inside-a-vietnamese-government-quarantine/.

World Bank. 2020. 'Taking Stock, July 2020: What Will be the New Normal for Vietnam? The Economic Impact of Covid-19.' Hà Nội: World Bank. Accessed 10 February 2021. https://openknowledge.worldbank.org/handle/10986/34268. World Health Organization (WHO). 2021. 'Viet Nam Coronavirus Disease 2019 (COVID-19) Situation Report \#327.' Report as of 7 March 2021. Accessed 13 March 2021. https:/www.who.int/vietnam/internal-publications-detail/ covid-19-in-viet-nam-situation-report-32.

\section{About the Authors}

Mirjam LE works in the field of Southeast Asian Studies at the University of Passau, Germany. Her PhD thesis focuses on small town urbanization and the production of urban space in Vietnam. Her research interests involve urbanization and state-society relations in Vietnam, especially processes of self-organization and citizenship.

Franziska Susana NICOLAISEN works as a freelance consultant for political foundations on topics of urbanization and education in Vietnam and Southeast Asia. Her Master thesis at the University of Passau, Germany, is on sustainable urban mobility in Vietnam. Her research interests are citizenship, social movements, and urbanization in Vietnam. 



\section{PART IV}

The Global Economy and Transnational Migrant Labour in Asia during COVID-19 



\title{
12 The Coronavirus as the 'Final Straw' of the CCP's Performative Legitimacy?
}

\author{
A New Economic Model in the Post-COVID-19 Era
}

Catherine Yuk-ping LO

\begin{abstract}
While COVID-19 is still raging worldwide, the Chinese Premier Li Keqiang confidently stated that China had pulled out of the pandemic faster and in better shape than much of the world because of the 'hard work and sacrifice of [the] entire nation'. However, this 'hard work and sacrifice' in curbing the spread of COVID-19 came at a price. The global COVID-19 crisis has further worsened the Chinese Communist Party (CCP)'s 'shrinking' performative legitimacy because it has led to a slowdown of economic growth. Considering the ongoing Sino-US trade disputes and the rising suspicion of China and Chinese firms in western economies, the chapter examines to what extent the CCP can save its performative legitimacy through the new economic strategy dubbed the 'dual circulation strategy'.
\end{abstract}

Keywords: dual circulation strategy, non-pharmaceutical interventions, Wuhan lockdown, performative legitimacy

\section{Introduction}

We live in unprecedented times. COVID-19 has become a pandemic that is having tremendous impacts on societies around the world. After the extent of the pandemic emerged, pharmaceutical companies began to pour considerable efforts into finding a COVID-19 vaccine. While several promising vaccines have been launched since early 2021, before vaccinating the majority of the population, countries have employed an array of

Van der Veere, Anoma P., Florian Schneider, and Catherine Yuk-ping Lo (eds), Public Health in Asia during the COVID-19 Pandemic: Global Health Governance, Migrant Labour, and International Health Crises. Amsterdam, Amsterdam University Press 2022 DOI: 10.5117/9789463720977_CH12 
non-pharmaceutical interventions (NPIs) in attempts to flatten the infection curves. These include school and workplace closures, bans on public events, restrictions on mass gatherings, stay-at-home requirements, and internal movement limits.

China is no exception. Three weeks after the first officially reported cases in China, the Chinese authorities ordered a lockdown of Wuhan and its neighbouring cities for a total of 76 days. Travel in and out, for any reason, was prohibited. Authorities stopped public transport and banned most private cars. The authorities suspended free movement and started enforcing mandatory quarantine (BBC News 2021a). While it was a priority to contain COVID-19 as efficiently and quickly as possible, the NPIs China used are likely to have both short and long-term economic repercussions on the Chinese economy. This chapter will first discuss these impacts. After this, it will discuss the extent to which the Chinese Communist Party (CCP) can sustain its performative legitimacy by adopting a new economic model, which has been called a 'dual circulation economy'. It will also discuss the implications of Chinese economic development in the post-COVID-19 era. In this discussion, the chapter will consider the ongoing Sino-US political disputes and the rising suspicion of China and Chinese firms in Western economies.

\section{Shaking Performative Legitimacy: Economic Impacts of COVID-19 NPI Measures}

The legitimacy of a state can be defined as 'the belief that in spite of shortcomings and failures, the political institutions are better than others that might be established and [that these institutions] therefore can demand obedience' (Yang and Zhou 2015, 70). Weber $(1978,28)$ proposed three ideal-typical aspects of legitimacy as the basis of state power: First, a state enjoys traditional legitimacy when the people see its power as inherited or always existent. Second, a state has charismatic legitimacy when the state's leader or leaders are perceived as having exceptional quality as a result of their experiences or personal attributes. Finally, a state possesses legal legitimacy when the state's power is derived from a set of judicial and administrative principles that bind all members of society. Based on the Weberian classification, Yang and Zhou $(2015,70)$ developed three pillars of legitimacy with which state power can be justified, including legal-electoral, ideological, and performance legitimacy. A state's justification of its power is based on legal-electoral legitimacy when top leaders are elected by the 
public. Meanwhile, ideological legitimacy means that a state's right to rule is justified by a specific value system. Finally, performance legitimacy implies that a state's right to rule is justified by its economic and/or moral performance (Yang and Zhou 2015, 70).

In the case of the CCP, the Party lacks legal-electoral legitimacy because it is not democratically elected by the public, based on liberal understandings of democracy and democratic election (Yang and Zhou 2015, 70). ${ }^{\text {T The role of }}$ communism in giving ideological legitimacy to the CCP has been viewed to be declining, because the party has implemented capitalist Open Door economic policies since the 1980 s (Yang and Zhou 2015, 73). ${ }^{2}$ The CCP's ideological legitimacy was further destabilized in the aftermath of the crackdown of the democratic movement during the 1989 Tiananmen Incident (Zheng 2008, 788). ${ }^{3}$ Therefore, in the absence of political legitimacy and with fading ideological legitimacy, performative legitimacy serves as the main pillar that justifies the rule of the CCP (See Zhao 2017). However, the performative pillar has been weakened since 2012 because the Chinese economy has reached the limits of its quantitative growth, which had been driven by investment and exports over the past thirty years. China's real GDP growth rate was on average more than $10 \%$ for the period 1981 through 2010 , but it dropped to $7.86 \%$ in 2012 and to $6.11 \%$ in 2019 (The World Bank 2019). The Chinese authorities refer to this gradually declining trend as the 'new normal'. This concept was first used by Chinese President Xi Jinping to describe China's economic development to an international audience when he delivered a keynote speech at the opening ceremony of the Asia-Pacific Economic Cooperation

1 In a democratic country: (a) there is political pluralism; citizens are permitted to participate in the political system, (b) legitimacy is obtained via a fair and free election, (c) the human rights of the citizens are protected, and (d) the state is founded on the principle of the Rule of Law. That is, the law applies equally to all citizens, including the president and those who make and enforce the law. Therefore, China lacks legal-electoral legitimacy, a point also argued by Yang and Zhou (2015).

2 There was a shift from ideological to performative legitimacy during the 1980 . The open-door policy attracted a large number of overseas Chinese from Taiwan, Hong Kong and other parts of the world. These people not only brought into China new ways of life and ideas, but shocked their mainland relatives by their affluence. The old state propaganda on the superiority of socialism over capitalism, that many Chinese people had believed in, was invalidated (See Yang and Zhou 2015). 3 After the crackdown on demonstrations in Tiananmen Square in 1989, the Chinese government knew that continuous economic reform was key to remaining in power. Facing resistance from the leftists in the Party, Deng started his southern China tour in 1992, calling for more radical economic reforms. Deng's southern China tour was decisive. After the tour, top Chinese leaders all stepped out to show support, leftist propaganda disappeared from mainstream media, and the state seemed to have quietly abandoned communist ideology as the basis of state legitimacy (See Yang and Zhou 2015). 
(APEC) CEO summit in November 2014 (Xinhua 2014). Apart from slowing economic growth, the continuous rise in the debt-to-GDP ratio in China has further jeopardized the CCP's performative legitimacy. As of 2009, China's total corporate, household, and government debts amounted to $189 \%$ of its GDP (China Power Team 2017). The debts reached 303\% of GDP in the first quarter of 2019 (Reuters 2019). Although a debt-to-GDP ratio exceeding $100 \%$ is not unusual, China's credit expansion over the past decade has been so large and rapid that this could threaten the long-term stability of the CCP's performative legitimacy. The three pillars of legitimacy developed by Yang and Zhou $(2015,71)$ suggest that a one-party government could collapse if the performative pillar is no longer sustainable. As a result, some commentators have speculated that a big crisis, like COVID-19, could be the 'ultimate' cause of the collapse of the one-party system in China (Zhou 2020).

The CCP, however, has attempted to boost its legitimacy in the way it contained the COVID-19 outbreak. On 20 January, President Xi gave 'important directions' for responding to the coronavirus (Xinhua 2020). This was the first public speech that Xi made after the first cases were reported in China in December 2019 (Wang et al. 2020). In Chinese bureaucratic politics, officers tend to care about self-preservation. Local officials fear to take actions that would anger their superiors; they would rather wait for their superiors to make decisions and are only accountable to their superiors instead of to the people ( $\mathrm{Li}$ 2020). As such, when the top leader openly admits to an outbreak, all related departments and officials understand that they are granted the permission to react to the outbreak. Following the speech given by Xi, two State Council special meetings were held, the first on 20 January and the second between 23 and 24 January. On 26 January, the Chinese authorities established a policymaking and coordination body in the State Council, chaired by Premier Li Keqiang and named the Central Leading Small Group for Work to Counter the New Coronavirus Infection Pneumonia Epidemic, also known as the Coronavirus Leading Small Group (China Daily 2020).

This proactive approach from the Chinese authorities resulted in a series of non-pharmaceutical interventions (NPIs) that some commentators have described as being 'draconian' (Gunia 2020). One well-known measure that the Chinese government implemented on 23 January was the lockdown of Wuhan and two neighbouring cities. The restriction banned travel in and out of the three cities for any reason. Authorities suspended public transport and banned most private cars. They eventually began house-to-house inspections and enforced quarantine (BBC News 2021a). In terms of the number of people being quarantined (which was around twenty million in three cities), the scale of lockdown was unprecedented in human history. 
Other cities in China were also placed under semi-lockdown. For instance, many residential districts and housing estates put in place a system of 'enclosed management'. Under this system, non-residents were not allowed to enter residential districts. One person in each household was permitted to go out for grocery shopping every two to five days. This person had to wear a surgical mask and present their identity card upon entering and leaving. They were given a temperature check at the gate (Gunia 2020). The government has also used a system to monitor the health status of individuals through digital barcodes on an app (the Alipay Health Code) that is installed on people's smartphones (Burgers and Sicinski 2020, 15).

To deal with the outbreak, the Chinese government also built two new hospitals in Wuhan, with construction of these taking only ten days. These hospitals can admit and treat around 2000 patients (Williams 2020). Another sixteen makeshift hospitals were later set up in Wuhan to admit patients with mild symptoms. In 2003, during the Severe Acute Respiratory Syndrome (SARS) outbreak, the Chinese government had similarly built a hospital on the outskirts of Beijing, with construction taking seven days in total (BBC News 2020). This previous experience with the rapid construction of emergency hospital facilities may have helped the Chinese government in its response to the new COVID-19 pandemic seventeen years later.

China was the first country to implement large-scale lockdown measures and also the first country to ease COVID-19 restrictions. At the opening of the National People's Congress (NPC) on 22 May, Premier Li confidently stated that China had pulled out of the pandemic crisis faster and in better shape than much of the world because of the 'hard work and sacrifice of our entire nation' (Li 2020).

However, this claimed 'hard work and sacrifice' of the 'entire nation' in curbing the global spread of COVID-19, came at a price. Global supply chains have been disrupted due to complete and partial lockdowns in various industrial provinces of China. One prominent example of such disruption has been the way in which COVID-19 has affected the China-based production of Apple's iPhone. In February 2020, Apple warned of global 'iPhone supply shortages' as a result of its Chinese factories being shut because of the coronavirus outbreak. The Californian company told investors that it would fail to meet its quarterly revenue target of US $\$ 63-67$ billion because of both a 'temporarily constrained' supply of iPhones, as well as a dramatic drop in Chinese shoppers during the health crisis (Neate 2020).

In February 2020, the manufacturing purchasing managers' index (PMI) registered $35.7 \%$, which was the lowest it had ever been, indicating a serious 
contraction of manufacturing activity. ${ }^{4}$ However, the figure released in August 2020 showed that the index rebounded to its baseline of $50 \%$ (National Bureau of Statistics of China 2020). A private manufacturing survey in China, the Caixin Manufacturing Purchasing Managers' Index (PMI), also indicated that manufacturing activity expanded in September with an index figure of $53 \%$ (Trading Economics 2020). Furthermore, China's economy has seen a strong rebound since July 2020, from a contraction of $6.8 \%$ in the first quarter of 2020 to a positive growth of $6.5 \%$ in the fourth quarter of the same year (BBC News 2021b). Overall, China's economy grew $2.3 \%$ in 2020 , making it the only major economy that had a positive GDP expansion during that year (BBC News 2021b). Nevertheless, despite these positive figures, the prospects for economic development in China remain uncertain. China's key trading partners, including South Korea, Japan, Europe, and the US, are still struggling with the impact of coronavirus. That the Chinese government did not set a target for economic growth during the 2020 National Congress might imply that the authorities are being cautious about COVID-19's impact on other economies and the possibility that COVID-19 could resurge in China.

\section{US-China Economic Decoupling amid the Sino-US Cold War}

Before the COVID-19 outbreak, the CCP's performative legitimacy had already been challenged as a result of changes in the long-standing US policy of engagement with China. The radical turn to a more critical US posture towards China was first seen in the speech delivered by former Vice President Mike Pence at the Hudson Institute in October 2018 (White House 2018). Another speech delivered by Pence in 2019 then further outlined the end of US engagement with China:

As history will surely note, in less than three years, President Donald Trump has changed that narrative forever. No longer will America and its leaders hope that economic engagement alone will transform Communist China's authoritarian state into a free and open society that respects private property, the rule of law, and international rules of commerce (White House 2019).

4 PMI is a critical indicator of China's manufacturing activity. An index value above $50 \%$ indicates a positive development in the industrial sector, whereas a value below $50 \%$ indicates a negative situation. 
The speeches by Pence have been materialized in a 'trade war' between China and the US. The US delivered three rounds of tariffs on Chinese goods in 2018, then a fourth round in September 2019. Together, these mean that the US has imposed tariffs on more than US $\$ 36$ o billion of Chinese goods (Yong 2019). Meanwhile, in response to the US tariffs, China has imposed tariffs on more than US $\$ 110$ billion of US products (Yong 2019). Negotiations between the two sides resulted in the 'phase one' deal signed on 15 January 2020. China agreed to increase purchases of American products and services by at least US\$200 billion (The Straits Times 2020). The deal also includes stronger Chinese legal protections for intellectual property rights, and to some extent China also made concessions to financial services by agreeing to speed up the offering of business licenses.

While the Sino-US trade war is still ongoing, the current pandemic has accelerated the decoupling of the Chinese and American economies (Rachman 2020). The naming and origin of the new coronavirus is one source of diplomatic tensions between the two countries. The virus was called 'Wuhan Pneumonia' (Wuhan feiyan) by the Chinese authorities when the first cases were reported in Wuhan. Later, the central authorities replaced the name 'Wuhan Pneumonia' with 'New Coronavirus' (xin guangzhuang bingdu) so that people in other parts of the world would not connect the virus with China. To divert the anger of domestic and international audiences regarding the initial slow response to the outbreak, in mid-March 2020, Chinese Foreign Ministry spokesperson Zhao Lijian promoted the theory that the virus had originated in the US and was brought to Wuhan by a US delegate who attended the Military World Games (Westcott and Jiang 2020). Responding to the Chinese accusations about the spread of the 'American coronavirus' to Wuhan, President Trump engaged in a war of words by framing the disease as the 'Chinese virus'.

In May 2020, Trump also announced the termination of the US's relationship with the WHO. This can be seen as another move by the US to show dissatisfaction with the ostensibly growing Chinese influence in the international organization. Trump alleged that, by covering up the COVID-19 outbreak, the Chinese government had caused the loss of more than 100,000 lives in the US and over one million lives worldwide. He also alleged that the WHO has been effectively controlled by Beijing. Based on the survey conducted by the Pew Research Centre in 2020, around two-thirds of Americans (64\%) say 'China has done a bad job dealing with the coronavirus outbreak'. Around three-quarters (78\%) 'place a great deal or fair amount of the blame for the global spread of the coronavirus on the Chinese government's initial handling of the COVID-19 outbreak in Wuhan' (Silver et al. 2020). 
The political rift between the US and China has deepened during the COVID-19 pandemic, resulting in further economic decoupling between Beijing and Washington. During 2020, the Chinese smartphone apps TikTok and WeChat were singled out for attention by the Trump administration. In mid-September 2020, the US Department of Commerce said that it would ban both TikTok and WeChat from app stores and would bar the apps from accessing critical Internet services in the US (Arbel et al. 2020). A US federal judge later issued a temporary injunction blocking the WeChat ban. However, TikTok faced having to shut down operations unless its Chinese owner ByteDance could sell TikTok's US operations to a domestic company to satisfy US national security concerns (Arbel et al. 2020). The dispute was supposed to be settled when Trump approved a deal in which Oracle and Walmart partnered with TikTok to form a new, US-controlled company, but the final deal has been pushed back indefinitely by the Biden administration (Feiner 2021). That said, with the US Senate Foreign Relations Committee passing the Strategic Competition Act in April 2021, it is speculated more US decoupling actions might continue under the Biden administration (Hsu 2021).

\section{Chinese Responses to the US Economic Decoupling: Dual Circulation Strategy}

To sustain its performative legitimacy, the CCP has implemented consistent economic reforms during the past four decades. One of these has been the 'supply-side structural reform' (SSSR) policy implemented in 2015. This has attempted to reduce overproduction in selected products such as coal, iron, and steel. Another such policy is the 'Made in China 2025' plan announced in 2018. This plan intended to shift China from being an 'export and investment-led' economy to a 'demand and innovation-driven' economy by using government subsidies, mobilizing state-owned enterprises, and pursuing intellectual property acquisition to catch up with - and then surpass - Western technological prowess in advanced industries.

In response to the US's recent economic decoupling, in October 2020 China unveiled its own decoupling strategy, named the 'dual circulation strategy' (DCS). In this strategy, 'circulation' refers to the production and consumption of goods and services. The first or international circulation in the 'dual' formulation concerns maintaining integration with the rest of the world. The second or internal circulation focuses on increased reliance on domestic demand and reducing economic dependence on the rest of the 
world (Garcia-Herrero 2020). President Xi is demanding that China both continues its commitment to global integration and exports, or international circulation, and also emphasizes domestic production for home consumption, or internal circulation (Pettis 2020). The 'dual' formulation has become a key priority in the Chinese government's $14^{\text {th }}$ five-year plan (2021-2025), replacing the supply-side structural reform (SSSR) and 'Made in China 2025' designated in the previous five-year period (Huang 2021).

The concept of 'internal circulation' remains contested. Some analysts believe that it is an attempt to present old wine in a new bottle. A similar concept was proposed in 2011 by the then-premier Wen Jiabao in the country's $12^{\text {th }}$ Five-Year Plan, claiming that the Chinese government would prioritize domestic consumption-led growth over export-led growth (China's National People's Congress 2011). Pettis (2020) argues that internal circulation conflicts with international circulation. Boosting domestic consumption requires policies that would increase wages and benefits for workers. This would weaken international circulation, which requires low labour costs to maintain export competitiveness. Blanchette and Polk (2020) state that the dual circulation strategy will be inward-looking and that if the authorities focus on internal circulation, China will close its door to the outside world. Young (2020) suggests that China will retreat into the kind of 'self-reliance' developmental policy begun by Mao Zedong during the Chinese Civil War (i.e., 'regeneration through one's own efforts,' or ziligengsheng).

Given that the dual circulation strategy is the Chinese response to the US decoupling, internal circulation entails greater technological self-reliance. The vulnerability of Chinese companies to bans on sales of US computer chips has intensified China's drive to become self-sufficient in critical technologies. In light of the US sanctions, Huawei announced that a chip plant would be set up in Shanghai to secure supplies of semiconductors for its core telecom infrastructure business (Hille et al. 2020). Xi has likewise stepped up calls for China to achieve 'self-sufficiency' for crucial components. During a meeting of the CCP's Central Committee, Xi declared that China would make enhanced technological self-reliance a priority over the next fifteen years and would make it 'a strategic pillar of national development' (Buckley and Myers 2020). From a technological development point of view, China may benefit from the current situation because this could move it to shake off its over-dependence on US chips. That said, the success of international circulation depends on the openness of the existing liberal world order established by the US. If the US decides to further decouple from China, its allies might follow suit with similar policies. Recently, for example, Australia has decided to diversify its export markets and supply 
chains away from China. Some European countries have similarly begun to reconsider trade and investment ties with China (Johnson and Gramer 2020). Again, the dual circulation strategy cannot be successful in the absence of international circulation.

\section{Concluding Remarks}

In 2019, the CCP celebrated the $70^{\text {th }}$ anniversary of the founding of New China in 1949. Historically, one-party governments have rarely survived longer than 70 years. I would argue that because of a lack of ideological and politicalelectoral legitimacy, especially in recent years, economic performance has been the key pillar legitimatizing the CCP's rule. The slowdown of economic growth since 2015 and the possible financial repercussions of the Sino-US Trade War since 2018 have threatened to impact the Party's legitimacy. The COVID-19 crisis and the related NPIs that were implemented in China further risk eroding the CCP's performative legitimacy. Therefore, the CCP recently put forth the dual circulation strategy as a new economic model to respond to the US economic decoupling from China. While the internal circulation contributes to the advancement of Chinese technology and innovation, continuous US decoupling could have a detrimental effect on the success of this strategy.

\section{Acknowledgement}

I want to thank Yow Shuning for helping me with the data collection. Any errors remain my own.

\section{References}

Arbel, Tali, Matt O'Brien, and Matt Ott. 2020. 'US Bans WeChat, TikTok from App Stores, Threatens Shutdowns.' Associated Press, 19 September. Accessed 1 December 2020. https://apnews.com/article/national-security-china-archiveunited-states-a439eadorb 75 fc958c 722 daf 40 of $_{930}$ c.

BBC News. 2020. 'Coronavirus: The Hospital Built in a Matter of Days.' 2 February. Accessed 2 April 2021. https://www.bbc.com/news/in-pictures-51280586.

—. 2021a. 'Covid-19: China's Economy Picks Up, Bucking Global Trend.' 18 January. Accessed 20 January 2021. https://www.bbc.com/news/business-55699971. 
- 2021b. 'Wuhan Lockdown: A Year of China's Fight Against the COVID Pandemic.' 22 January. Accessed 4 April 2021. https://www.bbc.com/news/ world-asia-china-55628488.

Blanchette, Jude, and Andrew Polk. 2020. 'Dual Circulation and China's New Hedged Integration Strategy.' Centre for Strategic and International Studies, 24 August. Accessed 7 April 2021. https://www.csis.org/analysis/ dual-circulation-and-chinas-new-hedged-integration-strategy.

Buckley, Chris, and Steven Lee Myers. 2020. 'China's Leaders Vow Tech 'Self-Reliance.' Military Power and Economic Recovery.' The New York Times, 29 October. Accessed 1 December 2020. https://www.nytimes.com/2020/10/29/world/asia/ china-five-year-plan-communist-party.html.

Burgers, Emma, and Ryszard Sicinski. 2020. 'The Use of Apps to Fight COVID-19 in Mainland China.' In How Asia Confronts COVID-19 through Technology, Florian Schneider and Rogier Creemers (eds.): 15-24. Leiden: Leiden Asia Centre. https:// leidenasiacentre.nl/wp-content/uploads/2020/05/LeidenAsiaCentre-How-AsiaConfronts-COVID-19-through-Technology-3.pdf.

China Daily. 2020. 'White Paper - Fighting Covid-19: China in Action.' 8 June. Accessed 1 December 2020. https://covid-19.chinadaily.com.cn/a/202006/o8/ WS5edd8bd6a3108348172515ec.html.

China's National People's Congress. 2011. '12th Five-Year Plan (2011-2015) for National Economic and Social Development.' 14 March. Accessed 5 April 2021. https:// policy.asiapacificenergy.org/sites/default/files/12th\%2oFive-Year\%2oPlan\%2o \%282011-2015\%29\%2ofor\%2oNational\%2oEconomic\%2oand\%2oSocial\%2o Development\%20\%28EN\%29.pdf.

China Power Team. 2017. 'Does China Face a Looming Debt Crisis?' China Power, 7 September. Accessed 19 January 2021. https://chinapower.csis.org/ china-face-looming-debt-crisis/.

Feiner, Lauren. 2021. TikTok Sale to Oracle, Walmart Reportedly on Hold as Biden Administration Reviews. CNBC, 10 February. Accessed 4June 2021. https://www. cnbc.com/2021/02/10/tiktok-sale-to-walmart-oracle-takes-back-seat-as-bidenreviews-security-wsj-reports.html.

Garcia-Herrero, Alicia. 2020. 'Why China's ‘Dual Circulation' Plan is Bad News for Everyone Else.' Nikkei Asia, ${ }_{17}$ September. Accessed 1 December 2020. https://asia.nikkei. com/Opinion/Why-China-s-dual-circulation-plan-is-bad-news-for-everyone-else.

Gunia, Amy. 2020. 'China's Draconian Lockdown is Getting Credit for Slowing Coronavirus. Would it Work Anywhere Else?' Time, 13 March. Accessed 10 January 2021. https://time.com/5796425/china-coronavirus-lockdown/.

Hille, Kathrin, Yuan Yang, and Qianer Liu. 2020. 'Huawei Develops Plan for Chip Plant to Help Beat US Sanctions.' Financial Times, 1 November. Accessed 10 December 2020. https://www.ft.com/content/84eb666e-oaf3-48eb-8b6o-3f53b19435cb. 
Hsu, Sara. 2021. Senate's Strategic Competition Act Will Make China-US Relations Worse, Not Better. The Diplomat, 27 April. Accessed 4 June 2021. https:// thediplomat.com/2021/04/senates-strategic-competition-act-will-make-chinaus-relations-worse-not-better/.

Huang, Yukon. 2021. “Two Sessions' 2021: How China Can Fine-Tune its Dual Circulation Strategy to Boost Economic Growth.' South China Morning Post, 4 March. Accessed 4June 2021. https://www.scmp.com/comment/opinion/article/3123741/ two-sessions-2021-how-china-can-fine-tune-its-dual-circulation.

Johnson, Keith, and Robbie Gramer. 2020. 'The Great Decoupling.' Foreign Policy, 14 May. Accessed 18 December 2020. https:/foreignpolicy.com/2020/05/14/ china-us-pandemic-economy-tensions-trump-coronavirus-covid-new-coldwar-economics-the-great-decoupling/.

Li, Keqiang. 2020. 'Report on the Work of Government.' China Daily, 22 May. Accessed 18 December 2020. https://language.chinadaily.com.cn/a/202006/o1/ WS5ed46379a310a8b241159ce5.html.

Li, Yuan. 2020. 'Coronavirus Crisis Shows China's Governance Failure.' The New York Times, 4 February. Accessed 4 April 2021. https://www.nytimes.com/2020/02/04/ business/china-coronavirus-government.html.

National Bureau of Statistics of China. 2020. 'Purchasing Managers Index for February 2020.' 2 March. Accessed 19 December 2020. http://www.stats.gov.cn/english/ pressrelease/202003/t20200302_1729254.html\#: :text=Manufacturing\%20 Purchasing\%2oManagers\%2oIndex,percentage\%2opoints\%2ofrom\%2olast\%2o month.

Neate, Rupert. 2020. 'Apple Warns of Coronavirus Causing iPhone Shortages.' The Guardian, 17 February. Accessed 19 December 2020 . https://www.theguardian.com/technology/2020/feb/17/ apple-warns-of-coronavirus-causing-iphone-shortages.

Pettis, Michael. 2020. 'The Problems with China's 'Dual Circulation' Economic Model.' Financial Times, 25 August. Accessed 1 December 2020 . https://ftalphaville.ft.com/2020/o8/24/15982789460oo/ The-problems-with-China-s--Dual-Circulation--economic-model/.

Pompeo, Michael R. 2020. 'Communist China and the Free World's Future.' U.S. Department of State, 23 July. Accessed 1 December 2020. https://www.state.gov/ communist-china-and-the-free-worlds-future/.

Rachman, Gideon. 2020. 'The Decoupling of the US and China has Only Just Begun.' Financial Times, 17 August. Accessed 18 December 2020. https://www.ft.com/ content/9oood2bo-46of-438o-b5de-cd7fdb9416c8.

Reuters. 2019. 'China's Debt Tops 300\% of GDP, Now 15\% of Global Total: IIF.' 18 July. Accessed 20 January 2021. https://www.reuters.com/article/ us-china-economy-debt-idUSKCNiUDoKD. 
Silver, Laura, Kat Devlin, and Christine Huang. 2020. 'Americans Fault China for its Role in the Spread of COVID-19.' Pew Research Center, 3 July. Accessed 1 December 2020. https://www.pewresearch.org/global/2020/07/30/ americans-fault-china-for-its-role-in-the-spread-of-covid-19/.

The Straits Times. 2020. 'What's in the US-China Phase One Trade Deal?' 16 January. Accessed 1 December 2020. https://www.straitstimes.com/world/united-states/ whats-in-the-us-china-phase-one-trade-deal.

The World Bank. 2019. 'GDP Growth (annual\%)-China.' Accessed 19 January 2021. https://data.worldbank.org/indicator/NY.GDP.MKTP.KD.ZG?locations=CN.

Trading Economics. 2020. 'China Caixin Manufacturing PMI.' Accessed 1 December 2020. https://tradingeconomics.com/china/manufacturing-pmi.

Wang, Chen, Peter W. Horby, Frederick G. Hayden, and George F. Gao. 2020. 'A Novel Coronavirus Outbreak of Global Health Concern.' The Lancet vol. 395: 470-473. https://doi.org/10.1016/So140-6736(20)30185-9.

Weber, Max. 1978. 'The Nature of Social Action.' In Max Weber: Selections in Translation, W.G. Runciman and E. Mathew (eds.): 7-32 Cambridge: Cambridge University Press.

Westcott, Ben, and Steven Jiang. 2020. 'Chinese Diplomat Promotes Conspiracy Theory that US Military Brought Coronavirus to Wuhan.' CNN, 14 March. Accessed 31 January 2021. https:/edition.cnn.com/2020/03/13/asia/chinacoronavirus-us-lijian-zhao-intl-hnk/index.html.

White House. 2018. 'Remarks by Vice President Pence on the Administration's Policy toward China.' 4 October. Accessed 1 December 2020. https://www.whitehouse. gov/briefings-statements/remarks-vice-president-pence-administrationspolicy-toward-china/.

-. 2019. 'Remarks by Vice President Pence at the Frederic V. Malek Memorial Lecture.' 24 October. Accessed 1 December 2020. https://www.whitehouse. gov/briefings-statements/remarks-vice-president-pence-frederic-v-malekmemorial-lecture/.

Williams, Sophie. 2020. 'Coronavirus: How Can China Build a Hospital so Quickly?' BBC News, 31 January. Accessed 1 December 2020. https://www.bbc.com/news/ world-asia-china-51245156.

Xinhua. 2014. 'Xi's 'New Normal' Theory.' China.org.cn, 10 November. Accessed 10 January 2021. http://www.china.org.cn/world/2014-11/10/content_34012582. htm.

-. 2020. 'Xi Orders Resolute Efforts to Curb Virus Spread.' 2o January. Accessed 1 December 2020. http://www.xinhuanet.com/english/2020-01/20/c_138721535.htm.

Yang, Hongxing, and Dingxin Zhao. 2015. 'Performance Legitimacy, State Autonomy and China's Economic Miracle.' Journal of Contemporary China vol. 24: 64-82. https://doi.org/10.1080/10670564.2014.918403. 
Yao, Kevin. 2020. 'What We Know about China's 'Dual Circulation' Economic Strategy.' Reuters, ${ }_{15}$ September. Accessed 1 December 2020. https://www.reuters. com/article/china-economy-transformation-explainer-idUSKBN26ooB5.

Yong, Charissa. 2019. 'Tit-for-Tat: Timeline of US-China Trade Dispute.' The Straits Times, 6 May. Accessed 1 December 2020. https://www.straitstimes.com/world/ united-states/tit-for-tat-timeline-of-us-china-trade-dispute.

Young, Benjamin R. 2020. 'From China to the US, the 'Self-Reliance' Slogan is Back.' The Diplomat, 2 October. Accessed 1 December 2020. https://thediplomat. com/2020/10/from-china-to-the-us-the-self-reliance-slogan-is-back/.

Zhao, Suisheng (ed.). 2017. Debating Regime legitimacy in Contemporary China: Popular Protest and Regime Performance. New York: Routledge.

Zheng, Wang. 2008. 'National Humiliation, History Education, and the Politics of Historical Memory: Patriotic Education Campaign in China.' International Studies Quarterly vol. 52:783-806.

Zhou, Christina. 2020. 'China's Communist Party is at a Fatal Age for One-Party Regimes. How Much Longer Can it Survive?' ABC News, 4 January. Accessed 1 April 2021. https://www.abc.net.au/news/2020-01-05/ chinas-communist-party-is-at-a-fatal-age-for-one-party-regimes/11807138.

\section{About the Author}

Catherine Yuk-ping LO is an Assistant Professor at University College Maastricht, Maastricht University. She specializes in international relations and global health. Her current research interests include HIV/AIDS in China and India, infectious disease responses in Northeast and Southeast Asian states, antimicrobial resistance (AMR) challenges in the Global South and North, and also global health diplomacy. She is the author of HIV/AIDS in China and India: Governing Health Security (Palgrave Macmillan, 2015). Her book won the 2017 International Studies Association (ISA) Global Health Section Book Prize. Her works appear in such journals as the Australian Journal of International Affairs, Health and Policy Planning, Globalization and Health, and the Journal of Global Security Studies. 


\title{
13 Health Governance during the COVID-19 Pandemic
}

\author{
Reflections on Taiwan's Guest Worker Policy
}

\author{
Mei-Chun LIU
}

\begin{abstract}
Taiwan's government was quick to act against COVID-19 with a quarantine decree, mask mandates, detailed tracking of confirmed cases, and the nearly $100 \%$ coverage rate of universal health insurance. This approach proved successful during 2020. However, at the same time, Taiwan's 'guest worker policy' deprives migrant workers of the right to permanent residency/citizenship, freedom of employment, social security benefits, and residency arrangements. They lack access to health care and financial support, and they have faced wage cuts and dismissals during the COVID-19 pandemic, making them a vulnerable minority. This chapter argues that Taiwan needs to reconsider its 'divide and exclude' guest worker policy, not only for the sake of migrant workers themselves but also to safeguard public health.
\end{abstract}

Keywords: health governance, guest worker policy, Taiwan (Republic of China), health insurance, migrant labour, COVID-19

\section{Introduction}

The COVID-19 pandemic has brought the momentum of globalization to a near halt, causing unmeasurable ramifications in terms of economics, human rights, and social inequality. Taiwan's government was quick to act in tackling this unprecedented global health crisis. During the first year

\footnotetext{
Van der Veere, Anoma P., Florian Schneider, and Catherine Yuk-ping Lo (eds), Public Health in Asia during the COVID-19 Pandemic: Global Health Governance, Migrant Labour, and International Health Crises. Amsterdam, Amsterdam University Press 2022 DOI: 10.5117/9789463720977_CH13
} 
of the pandemic, its strategy proved successful, with only nine deaths and 909 confirmed cases before 30 January 2021.

The low infection rate achieved in Taiwan during this period can be attributed to various causes, such as widespread mask-wearing and an effective quarantine decree. The early success handling COVID-19 is also partly due to Taiwan's universal health insurance that covers everyone, including blue-collar migrant workers. In contrast to the benefits brought by this universal healthcare system, however, Taiwan also has a 'guest worker policy' that deprives migrant workers of the rights to permanent residency/citizenship, freedom of employment, and social security benefits, making them vulnerable during crises. This chapter both examines the successes Taiwan had dealing with COVID-19 during the first year of the pandemic and also looks at the ways that the pandemic has exposed the vulnerabilities of migrants in Taiwan. COVID-19 has revealed that migrants face disadvantages in access to health care and financial support, as seen in wage cuts and dismissals. The chapter argues that it is therefore time to reconsider the 'divide and exclude' nature of Taiwan's guest worker policy.

\section{Globalization and its Challenge to Public Health}

With proponents of globalization optimistically proclaiming the 'end of history' (Fukuyama 1992) and the benefits of a 'flat earth' (Friedman 2005), globalization seemed to herald a promising new world. However, as the so-called 'globalization' of the world has progressed, these prophesies have been turning into a bleaker picture. This is especially the case for those who have been denied a share in the new prosperity globalization has brought, something which is exacerbated by rising inequality among the northern and the southern hemispheres (Chomsky 2006, 2012; Stiglitz 2002, 2015). On the one hand, globalization has enhanced the free flow of people and capital, boosting the global economy. On the other hand, it has increasingly jeopardized state sovereignty, leaving nation-states subject to the consequences of heightened interconnectivity. This is something that has been made clear by the world's vulnerability to global pandemics.

Under conditions of increasing globalization, conflicts and turmoil have become more pronounced since the start of the new millennium with different regions hit by refugee crises and a series of new infectious diseases. Five new viruses have led to extensive human casualties over the past decade, namely $\mathrm{H} 1 \mathrm{~N}_{1}$ (2009), Polio (2014), Ebola in West Africa (2014), and Zika (2016) and Ebola in the Democratic Republic of Congo (2019). Each of these viruses was declared 
a Public Health Emergency of International Concern (PHEIC) by the World Health Organization (WHO). The devastating effect of virulent viruses has made global health governance an urgent issue on the international agenda in recent years, with calls for making it a joint global endeavour (Kickbusch 2016; Friedman and Lawrence 2017; Gostin, Moon, and Meier, 2020).

The COVID-19 pandemic, an unprecedented global crisis, has brought to the fore a pressing concern for the protection of fundamental human rights. In different countries, human rights have been jeopardized during the pandemic by the restriction of people's movement for health reasons, as well as a shortage of health care provisions. COVID-19 has devastated economies, livelihoods, and the way people interact with each other, meaning that concerted public health actions, both globally and locally, are now imperative.

\section{Migration and its Challenge to Global Health Governance}

The international community has been overwhelmed by the virulence and mutating adaptability of the COVID-19 virus, posing a real challenge to delivering effective, as well as coordinated, measures to ensure health safety for all. In one attempt to do so, the WHO launched the COVID-19 Solidarity Response Fund in partnership with the UN Foundation. This Fund is intended to collect donations and financially support public health initiatives seeking to contain the pandemic across the globe (WHO 2020). However, one question about the Fund, is whether it will recognize the plight of migrant workers in different countries. These migrant workers have been particularly hard-hit by the COVID-19 pandemic, often suffering mass lay-offs or wage cuts and thus facing hardships due to the global economic slow-down as well as lack of health protection.

The fact that migration is a significant public health issue and has pervasive global health implications has not yet received enough attention. Studies have shown that the abusive and exploitative treatment that many migrants encounter has led to a wide range of public health issues (Ottisova et al. 2016). COVID-19 has offered a watershed moment, prompting societies to re-examine the public health institutions and policy loopholes that have left those most marginalized even more destitute during the pandemic, especially with regard to access to health resources and information.

Amongst the Sustainable Development Goals of the UN, there is the goal of ensuring 'healthy lives' and promoting 'well-being for all at all ages' (United Nations 2020). However, even if this goal is largely being realized, 
disadvantaged populations still suffer from insufficient access to health services and lack the needed materials for personal protection as a result of discrimination, lack of access to health care services, and denial of welfare benefits (Kickbusch 2016). This is a reminder that even if a nation has excellent universal health insurance, this does not automatically guarantee equal health provision and safety for all unless marginalized segments of the population have received due attention.

In order to tackle the issues related to unequal health provision, a number of measures should be taken. As Zimmerman and Kiss (2017) suggest, preventive measures that address structural determinants (such as discrimination and constrained access to health care services) should be prioritized because of their enormous impact on migrants' health. It is crucial to have an inclusive decision-making mechanism through which migrants can have their voices heard. Looking at the case of Taiwan, the COVID-19 pandemic might be viewed as a disaster that can be turned into an opportunity by helping to expose the deficiencies in Taiwan's guest worker policy which follows the rule of 'dividing and excluding' that emerged from nationalism and discrimination against migrants. The use of this rule can be seen as detrimental not only to the migrants themselves, but to everyone living in Taiwanese society.

\section{Taiwan's 'Guest Worker Policy' in Danger of Breaching Human Rights}

In Taiwan today, the population of blue-collar migrants already outnumbers the population of Taiwan's officially recognized sixteen indigenous peoples. ${ }^{1}$ This is followed in size by marriage migrants totalling 565,299 persons, ${ }^{2}$ a significant sum considering Taiwan's population stands at 23,561,236 persons. ${ }^{3}$

1 Migrant workers include white-collar and blue-collar workers. Both are regulated through the Employment Service Law (1992), but receive differential treatment. White-collar migrant workers, mainly specialized/technical workers and language teachers, enjoy freedom of movement, choice of employers, and a duration of stay as long as their work permit is valid. All those rights are denied to the 713,454 blue-collar migrant workers (as compared to the 39,439 white-collar migrant workers, as reported by the end of April 2021).

2 Indicating migrants who enter Taiwan through marriage. Since the 1980s, men from lower social strata turned to Southeast Asian countries, mainly Vietnam, Indonesia, Thailand, and Philippines, in search for marriage partners. The annual number of marriage migrants has declined since 2004 .

3 Taiwan used to have four major ethnic groups with Fukienese as the largest, followed by mainlanders, Hakkanese and indigenous peoples, before the 1980s. Taiwan's census bureau 
Migrant workers are covered by Taiwan's highly renowned universal health insurance, which features low premiums, low co-pay, free access, and a nearly $100 \%$ coverage rate. However, the utilization rate of this insurance by migrants is minimal. This is due to several impeding features produced by Taiwan's guest worker policy. Instituted through the Employment Services Law of 1992, the migrant worker policy, often referred to as guest worker policy, guides the employment and management of migrant workers in Taiwan. This policy strictly confines blue collar migrant workers to predesignated employers and places of work even before entering Taiwan. If they leave their employers and start work elsewhere, they become illegal and undocumented, regardless of whether their reasons for leaving are legitimate or not. This policy allows employers to dismiss workers at will, often by sending migrants back to the brokers without worrying about legal consequences (Aspinwall 2020).

Although Taiwan has a high demand for migrant workers, its society has not been ready to accept them as part of the population (Wang 2011). Migrant workers are officially designated as complementary workers, not substitute workers. As a result, they can only sign fix-term temporary contracts which deprive them of the right to attain permanent residency, let alone citizenship (Tseng and Wang 2011). This is regardless of how long they have been working in Taiwan, with live-in domestic migrants allowed to work for a maximum of fourteen years and migrants working in factories and nursing homes for up to twelve years (Ministry of Labour 2018).

Migrant workers are, in practice, denied social welfare benefits, even if most are workers covered by health insurance and labour insurance, with the exception of live-in domestic migrant workers who only enjoy health insurance. Nevertheless, the benefits that migrant workers have from both insurances are not comparable with those that are enjoyed by locals, such as maternity benefits, unemployment benefits, and wage compensation for hospitalization due to occupational injuries as well as disease. ${ }^{4}$ This is

removed the question on ethnicity in 1990. Therefore, we can only estimate ethnic populations through sources such as the Council of Indigenous Peoples, the Hakka Affairs Council, the National Immigration Agency and the National Development Council, which all have their own surveys to monitor the population. An accurate estimate is beyond the scope of this chapter. The National Immigration Agency produces an annual statistical report on marriage migrants and work migrants, and the Council of Indigenous Peoples has their own survey.

4 Migrant workers are legally covered by both Universal Health Insurance and Labour Insurance, with the exception of domestic migrant workers who are covered by the former but not the latter. However, when it comes to the realization of those benefits promised by both insurances, blue-collar migrant workers have been disadvantaged due to their lack of information, and the complicated procedures required for filing claims, making it difficult to enjoy some of 
especially the case when they are claiming benefits for severe occupational injuries that require hospitalization and rehabilitation. In these cases, some employers have brokers who 'take back' injured migrants that have not medically recovered. These brokers will then send back the injured workers even before they are able to receive compensation from employers or their insurance benefits.

Living arrangements are another factor affecting the health of migrant workers. Migrant workers in Taiwan are often forced to accept dormitories prepared by brokers/agencies or employers. Employers set dormitory rules in order to effectively monitor and control workers, thus limiting migrants' freedom of movement outside factories and dormitories (Turton 2021). Living in the dormitories also means that migrants have to share fully packed rooms, bathrooms, and toilets (Everington 2018). These kinds of dwelling arrangements are dangerous to live in and make workers more susceptible to infectious diseases (Timmerman 2020). The outbreak of COVID-19 among migrant workers in Singapore in similar conditions exemplifies the health risks associated with close-quarter living conditions (Reuters 2020; Yi et al. 2020).

Another health risk for migrant workers lies in their reluctance to take sick leave for fear of wage loss and the risk of endangering possible contract renewal in the future. This unwillingness of migrant workers puts them at greater health risk, and can lead to unknown outbreaks (Wang et al. 2020; Aspinwall 2020). Moreover, it is difficult for undocumented migrant workers to seek medical help for fear of exposure and deportation. Another reason for their reluctance to seek medical help is financial, as they have to bear the full cost of medical expenses once they become undocumented, which also means losing their health insurance coverage. ${ }^{5}$

Migrant workers leave their employment and become undocumented for a number of different reasons. Migrant workers might seek to get

the benefits. In reality, for example, if female migrant workers get pregnant, it is unlikely that they are able to work until their due date without being dismissed by employers. Therefore, if pregnancy does occur, most of them choose to return to their home country, file a claim from their country of origin, or flee and work as an undocumented migrant in Taiwan.

5 According to Taiwan's migrant worker policy, employers have to provide National Health Insurance to migrant workers working in factories and households. However, once they flee, they lose their insurance. Taiwan's national health insurance is renowned for its fairly low premium (5.17\% of monthly income of which employers are obliged to pay $60 \%$, workers pay $30 \%$, and the government pays $10 \%$ ). It is also known for its extremely low fixed co-pay (about US $\$ 1.7$ for every clinic visit, US $\$ 3.3$ for every visit to a regional hospital, and US $\$ 5.7$ for a visit to a medical centre). Medical expenses will be fully covered by National Health Insurance Bureau. If something happens to them after they have become undocumented, workers may be liable for sizeable medical costs depending on the level of treatment required. 
away from unbearable working conditions, sexual assault, or inhumane treatment. Debt-ridden migrant workers have previously fled to avoid repatriation when their contracts were prematurely terminated due to the death of care recipients, plant closure, or mass redundancy. This form of contract termination invited a wave of criticism. As a result, the guest worker policy has recently undergone changes to allow migrants to seek new employment within a limited period. This is under the condition that the termination of their contract is not their fault. However, in such cases brokers are often inactive due to a lack of financial incentives to help migrants in their job search. Brokers frequently resort to regulatory violations by sending workers back home (Lan 2006; Hsia 2005, 343-344; $\mathrm{Gu}$ 2013, 96).

Migrant workers also tend to owe large amounts of debt to brokers in order to land jobs in Taiwan. This means that they have to work longer hours to earn enough to pay back these loans. This debt burden has been another reason that migrants flee from their employment positions and become undocumented (Olive 2020; Fleeing Migrants 2012). ${ }^{6}$ Once this happens, the government loses track of the migrants and is unable to receive their periodic health reports. A special immigration task force is then charged with hunting them down. This can force the workers to go into hiding. Critics from academia and human rights organizations have been vocal about the inadequacy of current regulations (Hsiao 2020).

In summary, the current guest worker policy restricts the mobility of migrants and their freedom of occupation. It therefore renders the power relations between migrants and employers extremely imbalanced, to the detriment of the migrants. This is what Tan (2014) describes as a 'governmentality of exclusion'. In his study of Singaporean society, he explains that it is the whole institutional apparatus that discriminates against those deemed 'less worthy' and unsuitable for inclusion. This applies to Taiwan as well. The stringent residency policy, denial of the freedom of occupation, as well as limited mobility, together function to drive migrant workers to leave their legal but much constrained employment, and become undocumented. When migrants are forced to become undocumented, the health risks borne by migrant workers increase. The exclusion of undocumented migrant workers from the universal health insurance system thus endangers the whole population.

6 Fleeing Migrants is a collection of 25 stories told by undocumented migrants in Taiwan. As has been discussed here, there are various reasons for them fleeing their employment, with debt burden being the most pressing. The original publication is in Chinese. 


\section{Tackling COVID-19 - Protective Measures and Remedies for Migrants}

The Taiwanese government was quick to take action when the COVID-19 pandemic emerged at the start of 2020. It immediately implemented thermal imaging at the border. It mobilized factories for the production of masks and coordinated health-insurance-contracted pharmacies and convenience stores to facilitate access to masks. It banned mass gatherings and suspended businesses such as nightclubs where social distancing was not possible. It also implemented mandatory wearing of masks in cinemas, department stores, hospitals, post offices, banks, and on public transportation (Yip 2020). Schools and offices also took preventive measures, such as restricted entry and placing thermal imaging cameras at entrances. Flights were reduced, or suspended, in accordance with the development of the pandemic in different countries or regions (Ministry of Foreign Affairs 2021). The government also implemented a fourteen-day quarantine measure for everyone coming from abroad.

These measures can partly explain why, during the first year of the COVID-19 pandemic, Taiwan saw very low infection rates when compared to other countries around the world. However, Taiwan's success in 2020 is not a guarantee for sustained success. Since April 2021 new variants of the COVID-19 virus have started spreading, resulting in 14,157 new confirmed cases and 575 deaths by 23 June 2021. The new virus outbreak has hit eight technology plants, leading to cluster infections among migrant workers, 400 being confirmed by 21 June 2021 (Huang 2021).

Although the clustered spread of COVID-19 among hundreds of migrant workers in Singapore at the end of March 2020 forced the Taiwanese government to reconsider their policies in order to offer assistance to migrant workers, 7 the issue of clustered living conditions did not receive ample attention, eventually leading to the aforementioned outbreak in 2021.

In order to reduce cross-border movement, migrant workers were also encouraged to stay in Taiwan and renew their contracts or take new placements. They were given a transportation subsidy to compensate for the delay or cancelation of their annual leave. Employers were also encouraged to apply for the extension of permits for migrants who had reached the maximum

7 This includes providing information about the pandemic at migrant service centres stationed at the airport, installing a hotline, establishing a multi-lingual website aimed at migrants, and using social media, pamphlets, as well as flyers to disseminate information in a bid to reach Taiwan's migrant populations (Workforce Development Agency 2020). 
duration of stay (Ministry of Labor 2020). They were asked to apply for shortterm employment permits of three months or six months for those migrant workers with contracts due to end. They were also encouraged to release migrant workers to other employers if there was a slowdown in business.

The government also put in place a measure to cover the hospital expenses incurred by infected migrant workers to encourage these workers to seek medical attention without worrying about the possible financial burden. Wage loss due to quarantine measures has been compensated by the government at NT $\$ 1000$ per day (approximately US $\$ 35$ ) when employers have not paid this (Yang 2020). Meanwhile, the government has also instructed that quarantine fees have to be paid by employers or agencies. It is forbidden for these fees to be transferred to migrant workers, with employers/agencies being fined if they attempt to do so (Everington 2020).

The government migrant worker policy has undergone several changes throughout the COVID-19 pandemic. Home quarantine applied to all incoming migrant workers as early as 19 March 2020. However, as the pandemic escalated, newly arrived live-in domestic migrant workers and factory migrant workers with re-entry permits were required to undergo centralized quarantine, while newly arrived factory migrant workers were subject to employer-provided home quarantines starting from 27 March 2020.

As the pandemic continued to escalate in Indonesia by the end of 2020, the government's policy was adjusted to include a temporary ban on all Indonesian workers (Lee 2020; Taiwan Centres for Disease Control 2020). Due to a growing number of confirmed cases and a rising death toll, a more stringent policy was issued on 19 May 2021 to ban all visa applications in accordance with stricter border control (Bureau of Consular Affairs 2021).

In order to encourage undocumented migrant workers to come out of hiding and abide by the preventative health measures, the National Immigration Bureau has adopted a three-month amnesty policy that exempts them from the confinement, re-entry ban, and fine that normally would apply when workers are arrested. In addition, the government has offered undocumented migrant workers a free anti-virus taxi service to and from COVID-19 testing centres, quarantine checks, and medication in order to prevent new infections from spreading. ${ }^{8}$ During this three-month amnesty period, nearly 8000 workers reported to the government (Lo 2020; National Immigration Agency 2020).

8 The government recruits and contracts the so-called 'anti-virus taxi' to offer migrant workers a free service that allows them to use a safe method of transport, in contrast to using regular transportation methods through which the virus might spread. 
The Taiwanese government also initially demanded that migrant workers on fishing vessels underwent a fourteen-day quarantine on their vessels. This rule also applied to those who have a low risk of contracting the virus, such as workers who have not anchored in other nations, have not interacted with other ships, have not changed crew members, and have not been inspected by foreign officials in the 30 days prior to their return to Taiwan. These rules were later tightened, requiring compulsory on-board health management of crew members who did not go ashore, if the ship was to set sail again within fourteen days. However, if crew members leave their ship and enter the community, the rules require either a 'one crew member one room' version of quarantine on the ship, or a hotel quarantine for fourteen days.

Eleven security posts were set up in three different cities to provide help and to monitor deep sea fishing vessels. The government has also provided masks to fishing associations and organizations of ship owners, through which crews can purchase them. Those undergoing the 'one crew member one room' quarantine also receive a pandemic protection bag that contains masks, a temperature recording card, sanitizer, towels, and a toothbrush. Ship owners receive a subsidy of $\mathrm{NT} \$ 1500$ per crew member per day (approximately US\$39) if they are quarantined on this basis (Fisheries Agency 2020).

During the first stage of the COVID-19 pandemic these measures aimed at migrant workers in Taiwan proved relatively successful, resulting in a low rate of infections and confirmed cases related to migrant workers.

\section{Taiwan's Guest Worker Policy: Ready for an Overhaul?}

After the first stage of the COVID-19 pandemic appeared to subside, Taiwan was quick in seeing business resume, schools open, and people getting back to their daily routines. Nevertheless, the number of employers who have put their employees on unpaid leave or have dismissed these employees in large numbers has hit a record high. Migrants are covered by labour insurance but are denied unemployment benefits, unlike their Taiwanese counterparts who are entitled to these benefits. Furthermore, migrant workers are also not entitled to severance pay because their labour contracts exclude this right. This means that, for some migrant workers, even though they have been able to survive the pandemic, they are likely to be in great debt as a result of having been placed on unpaid leave or having been dismissed. Many of these migrant workers might be described as being virtually invisible to 
policy makers, who continue to ignore the predicament of migrant workers due to the 'divide and exclude' principle that characterises Taiwan's guest worker policy.

Although Taiwan is a signatory of five major human rights conventions, these conditions have persisted. Taiwan has notably not signed the International Convention on the Protection of the Rights of All Migrant Workers and Members of Their Families. It can be argued that the key to improving Taiwan's human rights record lies in the way workers' basic human rights are protected, such as the freedom of occupation, freedom of movement, a right to family reunion, equal rights to employment and justice, and permanent residency. It is therefore time for Taiwan to transform its guest worker policy, a policy that is still used to structurally exploit migrant workers' vulnerability by depriving them of their labour rights.

\section{Looking Ahead: Inclusiveness and Solidarity}

The unprecedented global health crisis sparked by the COVID-19 pandemic has exposed the exclusionary shortcomings of Taiwan's guest worker policy. The COVID-19 pandemic has hit those most marginalized the hardest and has disenfranchised migrant workers, who have already long been excluded from the Taiwanese government's worker protections. The way in which Taiwan's guest worker policy deprives migrant workers of certain rights exemplifies how, in different countries, an 'us vs. others' mentality can prevent fair policy and impede global public health challenges in an era of globalization.

As Kickbusch (2016) argues, a paradigm shift is necessary in global health governance, as health governance has deepened rising inequalities. Any country that withholds health as a basic human right, especially to migrants, will be trapped in an ever-worsening health dilemma. Global health governance therefore requires international solidarity.

This pandemic offers a rare opportunity to re-examine what has been achieved in global health governance up until now, and what is left to be amended after the pandemic is over. Normative principles need to be established that require the international community to recognize the importance of committing to inclusiveness, and to incentivize governments to take concerted action so as to include non-state actors that deserve more attention. Ulrich Beck (2011) used the concept of the 'cosmopolitan imperative' to describe the urgency that modern societies face in addressing emerging global risks that cannot be confined in space or time. The same 
reflection also applies to any society where discrimination, prejudice, and exclusionary policies do no justice to those most vulnerable. The safety of those most marginalized matters significantly when public health is concerned. Therefore, the existing structural inequity of health governance demands a close review in order to safeguard all.

\section{References}

Aspinwall, Nick. 2020. 'Taiwan Accused of Failing to Protect Medical Rights of Southeast Asian Workers.' The Diplomat, 14 November. Accessed 1 January 2021. https://thediplomat.com/2020/11/taiwan-accused-of-failing-to-protect-medicalrights-of-southeast-asian-workers/.

Beck, Ulrich. 2011. 'Cosmopolitanism as Imagined Communities of Global Risk.' American Behavioral Scientist vol. 55, no. 10: 1346-1361. https://doi. org/10.1177\%2Fooo2764211409739.

Bureau of Consular Affairs. 2021. 'Entry Restrictions for Foreigners to Taiwan in Response to COVID-19 Outbreak.' Accessed 22 June 2021. https://www.boca. gov.tw/cp-220-5081-co6dc-2.html.

Chomsky, Noam. 2006. Failed States: The Abuse of Power and the Assault on Democracy. New York: Metropolitan Books.

-. Occupy. 2012. London: Penguin Books.

Everington, Keoni. 2020. 'Taiwanese Employers Who Dock Migrant Worker Wages Can Face NT\$30o,00o fine.' Taiwan News, 18 August. Accessed 1 January 2021. https://www.taiwannews.com.tw/en/news/3989715.

-. 2018. 'New Taipei officials investigate overcrowding after Vietnamese worker protest.' Taiwan News, 25 April. Accessed 1 January 2021. https://www.taiwannews.com.tw/en/news/3413933

Fisheries Agency. 2020. Regulations on Offshore Home Quarantine of Fishing Crew and Subsidy on Inspection as Well As Testing. 7 August. Accessed 1 January 2021. https://www.coa.gov.tw/COVID_19/index.php?theme=ws\&id=2511058.

Fleeing Migrants. 2012. Fleeing: Our Formosa, Their Imprisonment. Taipei: China Times Publishing Co.

Friedman, Eric A., and Lawrence O. Gostin. 2017. 'The Framework Convention on Global Health: A Call for Leadership from the Global Health Trio.' Health Affairs: Global Health Policy, 12 January. https://www.healthaffairs.org/do/10.1377/ hblog20170112.058262/full.

Gostin, Lawrence O., Suerie Moon, and Benjamin Mason Meier. 2020. 'Reimagining Global Health Governance in the Age of COVID-19.' American Journal of Public Health vol. 110, no.11:1615-1619. 
Gu, Yu-Ling. 2013. 'A Distorted “Semi-liberal Market of Migrant Workers” in Taiwan.' Taiwan Human Rights Journal vol 2, no.2: 93-112.

Hsia, Hsiao-Chuan. 2005. 'Taiwan's Immigrants and Migrant Workers Under Globalization.' In Taiwan's Social Problems, Li-Yun Chang and Hai-Yuan Chu (eds.): 328-367. Kaohsiung: Chuliu Book Co.

Hsiao, Sherry. 'Migrant Workers, Rights Groups Protest in Taipei.' Taipei Times, 14 December. Accessed 13 February 2021. https://www.taipeitimes.com/News/ taiwan/archives/2020/12/14/2003748684.

Huang, Tzu-ti. 2021. 'Migrant Workers in Taiwan's Miaoli Complain About Lousy Dorm Environment.' Taiwan News, 21 June. Accessed 22 June 2021. https://www. taiwannews.com.tw/en/news/4228624.

Kickbusch, Ilona. 2016. 'Global Health Governance Challenges 2016 - Are We Ready?' International Journal of Health Policy and Management vol. 5 , no. 6: 349-353. https://dx.doi.org/10.15171/ijhpm.2016.27.

Lan, Pei-chia. 2006. 'Legal Servitude and Free Illegality: Control and Exit of Migrant Workers.' Taiwan: A Radical Quarterly in Social Studies vol. 64: 107-150.

Lee, I-Chia. 2020. 'Indonesian Workers Face Temporary Ban.' Taipei Times, 1 December. Accessed 22 June 2021. https://www.taipeitimes.com/News/front/ archives/2020/12/01/2003747880.

Lim, Emerson. 2021. 'Migrant Workers Call for Legal Protections in Women's Day Rally.' Focus Taiwan, 8 March. Accessed 25 March 2021. https://focustaiwan. tw/society/202103080019.

Lo, Ping-San. 2020. 'Amnesty to Undocumented Migrant Workers to Amend AntiCovid19 Loopholes.' Apple Daily, 11 December. Accessed 29 March 2021. https:// tw.appledaily.com/forum/20201211/SSSK43GEWRGF5JQXI7I2SCTYZ4/.

Ministry of Foreign Affairs (MOFA). 2021. 'Entry Restrictions for Foreigners to Taiwan in Response to COVID-19 Outbreak.' Bureau of Consular Affairs, Ministry of Foreign Affairs, Republic of China (Taiwan). Last updated 8 February 2021. Accessed 13 February 2021. https://www.boca.gov.tw/cp-220-5081-co6dc-2. html.

Ministry of Labor. 2018. Employment Service Act. Last amended 28 November 2018. https://law.moj.gov.tw/Eng/LawClass/LawAll.aspx?PCode=Noogooo1.

- 2020. 'The Epidemic Situation in the Country of Origin of Migrant Workers Ras Risen to Level 3, and the Ministry of Labor Has Introduced Measures to Strengthen Epidemic Prevention Management.' https://www.mol.gov.tw/ announcement/2099/44880/.

National Immigration Agency. 2020. 'Practices on Addressing Challenge from Overstaying Migrants during Anti-Covid-19.' Internal Report Presented at Meeting of Migrant Workers' Human Rights Task Force Held at Ministry of Labor. 8 October. 
Oliver, Jeremy. 2020. 'Breaking the Vicious Cycle for Taiwan's Economic Migrants.' Taiwan Business Topics, 8 August. Accessed 1 January 2021. https://topics.amcham.com.tw/2020/o8/taiwans-economic-migrants/.

Ottisova, L., S. Hemmings, L. Howard, C. Zimmerman, and S. Oram. 2016. 'Prevalence and Risk of Violence and the Mental, Physical, and Sexual Health Problems Associated with Human Trafficking: An Updated Systematic Review.' Epidemiology and Psychiatric Sciences vol. 25, no. 4:317-341. https://doi.org/10.1017/ s2045796016000135.

Stiglitz, Joseph E. 2002. Globalization and its Discontents. New York: W.W. Norton \& Company.

-. 2015. The Great Divide: Unequal Societies and What We Can Do about Them. New York: W.W. Norton \& Company.

Taiwan Centers for Disease Control. 2020. 'Taiwan will Continue Suspending Entry of Indonesian Migrant Workers and will Lift the Measure Depending on Coronavirus Situation in Indonesia.' Accessed 22 June 2021. https://www.cdc. gov.tw/En/Bulletin/Detail/AbegjzXzg3mAAGkooTgVeA?typeid=158.

Timmerman, Antonia. 2020. 'In Taiwan's 'Container Houses' for Migrant Workers, Coronavirus Not the Only Health Risk.' South China Morning Post, 26 April. Accessed 13 February 2021. https://www.scmp.com/week-asia/people/article/3081227/ taiwans-container-houses-migrant-workers-coronavirus-not-only.

Turton, Michael. 2021. 'Notes from Central Taiwan: Everyday Life As the 'Other'.' Taipei Times, 1 February. Accessed 25 February 2021. https://www.taipeitimes. com/News/feat/archives/2021/02/01/2003751553.

United Nations. 2020. 'Ensure Healthy Lives and Promote Well-being for All at All Ages.' Department of Economic and Social Affairs, Sustainable Development. Accessed 13 February 2021. https://sdgs.un.org/goals/goal3.

Wang, Hong-Zen. 2011. 'Immigration Trends and Policy Changes in Taiwan.' Asian and Pacific Migration Journal vol. 2o, no. 2: 169-194. https://doi.org/10.1177\% 2Fo11719681102000203.

Wang, Hong-zen, Pei-chia Lan, Yen-fen Tseng, Chia-ling Wu, and Chiung-chih Chen. 2020. 'Reaching out to Undocumented Workers is Necessary to Contain COVID-19 Outbreak.' Commonwealth Magazine. Accessed 25 February 2021. https://english.cw.com.tw/article/article.action?id=2667

Workforce Development Agency, Ministry of Labor. 2020. 'Covid-19 Employment Guidelines: Migrant Workers Precautions for Work, life, and Going out Management.' 24 April. Last revised 7 May 2020. https://fwas.wda.gov.tw/upload/ download/agb47afa24c43407d27de45f408cd335611fab29.pdf.

World Health Organization (WHO). 2020. 'COVID-19 Solidarity Response Fund.' https://www.who.int/emergencies/diseases/novel-coronavirus-2019/donate. 
Yang, Sophia. 2020. 'Taiwan Employers, Brokers Must Cover Quarantine Fees for Migrant Workers.' Taiwan News, 27 November. Accessed 25 February 2021. https://www.taiwannews.com.tw/en/news/4063088.

Yang, Wen San. 2014. A Study on Planning Ethnic Statistics Project in Taiwan. National Development Council. Accessed 21 March 2021. https://ws.ndc.gov.tw/ Download.ashx?u=LzAwMSghZGipbmlzdHJhdGgyLzEwL_JlbGZpbGUvNjE5 MC8xNTUyNi8wMDYxMjUzXzEucGRm\&n=5peP576k57Wx6KiILnBkZg\%3D $\%{ }_{3}$ D\&icon=.pdf.

Yi, Huso, Shu Tian Ng, Aysha Farwin, Amanda Pei Ting Low, Cheng Mun Chang, and Jeremy Lim. 2020. 'Health Equity Considerations in COVID-19: Geospatial Network Analysis of the COVID-19 Outbreak in the Migrant Population in Singapore.' Journal of Travel Medicine vol. 28, no. 2 (March): taaa159. https:// doi.org/10.1093/jtm/taaa159.

Yip, Hilton. 2020. 'Fear of China Made Taiwan a Coronavirus Success Story.' Foreign Policy, 16 March. Accessed 13 February 2021. https://foreignpolicy.com/2020/03/16/ taiwan-china-fear-coronavirus-success/.

Zimmerman, Cathy and Ligia Kiss. 2017. 'Human Trafficking and Exploitation: A Global Health Concern.' PLoS Medicine vol. 14, no.11 (2017): e1002437. https://doi. org/10.1371/journal.pmed.1002437.

\section{About the Author}

Mei-Chun LIU is a Professor at the Institute for Labor Research, School of Social Science, National Chengchi University, Taipei, Taiwan. She earned her PhD in Sociology at the University of Southern California, US. She is currently chairperson of the Taiwan Public Health Promotion Association, a former chairperson of the Taiwan Higher Education Union and the Taiwan Health Reform Foundation, and a committee member of the New Immigrants Development Fund. Between 2016 and 2020, she served as a member of the Human Rights Committee of the Presidential Office. 



\title{
14 Public Health and Capitalism in Japan
}

\author{
The Impact of Labour Market Challenges and Welfare on \\ Public Health
}

Saori SHIBATA

\begin{abstract}
Attempts by the World Health Organization (WHO) and national governments to provide direction on public health have been affected by the socio-economic institutions present in different countries. The different national models of capitalism that are in place in different countries have had an impact upon the capacities of these countries to deal with public health during the COVID-19 pandemic. This chapter introduces the relationship between public health and national models of capitalism by looking at the case of Japan, and argues that the problems faced by people as a result of Japan's neoliberalized labour market and welfare system have created a number of obstacles to the successful management of the pandemic.
\end{abstract}

Keywords: public health, Japan, capitalism, labour market, neoliberalism, COVID-19

The World Health Organization (WHO) has received much criticism with regard to the legitimacy and effectiveness of its handling of the COVID-19 pandemic, with many political leaders being especially critical. This has made more evident than ever the challenges that international organizations, such as the WHO, face as they seek to coordinate international communities (NHK 2020). The attempts by the WHO, as well as by national governments, to provide direction on public health have been affected by the socioeconomic institutions present in different countries. The national models of capitalism in place have had an impact upon the capacities of different countries to deal with public health.

Van der Veere, Anoma P., Florian Schneider, and Catherine Yuk-ping Lo (eds), Public Health in Asia during the COVID-19 Pandemic: Global Health Governance, Migrant Labour, and International Health Crises. Amsterdam, Amsterdam University Press 2022 DOI: 10.5117/9789463720977_CH14 
This chapter first introduces the relationship between public health and national models of capitalism. Here, it highlights the impact of different socio-economic institutions (especially the labour market and welfare system) upon public health. After this, the chapter demonstrates how workers' problems are intertwined with their health. The chapter then demonstrates how challenging it has been for the WHO to address the pandemic and public health in different nations. This has been challenging because of how its attempts to deal with the pandemic have been influenced by the socio-economic institutions that are present in different nations.

In some nations, these socio-economic institutions include deep-rooted labour market problems that have been produced through an ongoing process of neoliberalization. This is the case, for instance, in Japan. The chapter then goes on to show that Japan's neoliberalized welfare system also impacts public health and increases social and health risks for many members of the public. Finally, it argues that the problems people face in the labour market and the welfare system have created a number of obstacles to the successful management of the pandemic and the implementation of necessary public health measures.

\section{WHO, Capitalism, and Public Health}

The national model of capitalism in place in any one country and global capitalism as a whole both significantly influence how public health is achieved (Sell and Williams 2020; Hernández-Álvarez et al. 2020; Hunter and Murray 2019). Many national models of capitalism function in states with a substantial welfare system. However, this system has proven unable to remove the market logic from public health in general, as well as in terms of access to healthcare services and essential medicines (Sell and Williams 2020, 4). Neoliberalism, and the associated preoccupation with market fundamentalism, has seen a prioritization of profit-seeking and austerity. It has also made work more precarious, resulting in growing economic insecurity for workers. This market logic, and particularly the drive for austerity, has led to widespread cutbacks in health services as well as market-driven reforms that have limited the availability of healthcare. During the ongoing COVID-19 pandemic, these conditions have created the potential for devastating consequences to public health (Sparke 2020, 1). Health is not an accidental outcome, but is 'shaped by people's location in terms of generational wealth, poverty and income inequalities within a wider 
national and global structure of accumulation' (Sell and Williams 2020, 4). As An and Tang $(2020,793-796)$ highlight, both institutional infrastructure and system capacity influence pandemic crisis management. Crucial factors for pandemic management include the capacity of public health institutions, healthcare facilities, medical services, information management technology, and regulatory systems.

This chapter argues that in order to understand the impact of the COVID-19 pandemic upon public health in Japan, we need to consider the country's institutionalized structures of inequality. In Japan, the medical and healthcare system, welfare system, health insurance system, and the labour market system are key socio-economic institutions that together have largely determined the extent to which the pandemic and public health have been handled. In other words, the model of capitalism present in Japan, as well as the existing patterns of social inequalities in public health, have had a crucial influence on how the pandemic has been managed.

The impact of the pandemic has depended on wealth, poverty, and income inequalities, within a wider national structure of capital accumulation. For instance, in some nations markets fail to deliver access to healthcare to all of the population when this access is dependent upon the ability to pay health insurance contributions, or when people are denied access to basic healthcare. Labour market conditions can also impact how the pandemic affects people. If people lose their jobs and become unemployed during a public health crisis, this can present significant risks to them and their families. Where national welfare systems provide insufficient coverage, this can mean that vulnerable people bear considerable risks during a pandemic (see also Nguyen's contribution in this volume).

The WHO has sought to advise national governments about responding to the pandemic by issuing a range of guidelines and measures relating to public health, local communities, domestic violence, quarantine, food safety, and safe workplaces (WHO 2020a). However, these guidelines and measures have so far had limited effects. For example, the advice given by the WHO has had a limited effect on securing public health in Japan. This is in large part due to the WHO's limited ability to deal with questions such as job security and welfare provisions, which play an essential role in addressing public health. In particular, socio-economic institutions have had a considerable effect on health governance and the unequal ways in which people in Japan have experienced the COVID-19 public health crisis. 


\section{Labour Market Challenges and Public Health}

A number of labour market reforms have sought to address problems faced by workers in Japan. These include the structural reforms and Work Style Reform (hatarakikata kaikaku) that were part of the so-called 'Abenomics' policies adopted by former Prime Minister Shinzo Abe. These reforms involved an increase in the minimum wage, an attempt to move workers on non-regular contracts to regular contracts, and efforts to encourage a shortening of working hours (Shibata 2020). However, the Abe government's priority has been the pursuit of labour market flexibility. This means that the proportion of non-regular workers, or those who do not have long-term employment security, within Japan's labour market has remained high, amounting for nearly $40 \%$ of the total workforce. The precarious situation faced by many non-regular workers has not improved under Abenomics (Shibata 2020).

The increase in the number of non-regular workers does not necessarily mean an increase in inequality; not all non-regular workers are precarious, and the employment situation surrounding non-regular workers has become complicated (Imano 2020). Nevertheless, it is under the current labour market conditions that non-regular workers were the first group of workers to face dismissals as a result of the COVID-19 pandemic. Such dismissals were termed 'corona dismissals' by the media, who announced a 'significant unemployment era' (Toyo Keizai Online 2020). These dismissals have seen the number of unemployed grow from 1.5 million at the end of 2019 to almost 2 million in May 2020 (Nihon Keizai Shimbum 2020). This also resulted in a rise in the unemployment rate, from $2.4 \%$ in 2019 to $3.1 \%$ in October 2020 (MHLW 2020).

In addition, workers were denied access to, or received reductions in, the 'absence allowance' that they were supposed to receive from employers. This 'absence allowance' was a government scheme that promised $80 \%$ of wages to staff who were unable to work because COVID-19 had forced the temporary closure of the companies where they worked. The government also provided other financial support, but the absence allowance was the most comprehensive financial support available, covering the majority of workers who were not able to work as a result of COVID-19. The allowance promised to guarantee workers' wages during the pandemic. Despite this guarantee, $24 \%$ of non-regular workers reported that their employers refused to provide the allowance (Nishinihon Shimbum 2020). Not receiving this allowance can impede workers' access to medical and healthcare services, because this access is dependent on their ability to pay healthcare insurance contributions. It can particularly lead to difficulties accessing medical 
healthcare services for foreign workers, female workers, and precariously employed non-regular workers. In particular, foreign workers faced a higher risk of losing their jobs and were more likely to receive low wages, both of which represent obstacles to public health. These workers are often ineligible for Japan's health insurance system while also lacking the informal family networks that offer an alternative means for securing healthcare and social support (Sawada 2018). While these problems existed before this, the pandemic has magnified them.

In different nations including in Japan, gender-based discrimination has intensified during the pandemic. The WHO has used its briefing papers to address the potential for increased domestic violence against women during the pandemic (WHO 2020b). Although this has represented an important source of advice, it is the Japanese government that has had to take the initiative and address nationally specific issues in terms of gender inequality. In Japan, there is a large disparity between male and female workers' wages and employment status. Female workers have tended to be most burdened with home-making and domestic care for family members. This has led to a decline in female workers' participation in the labour market and a corresponding increase in the degree to which women are dependent upon their husbands or partners for health and medical care. This has put single female workers at a considerably higher public health risk.

Female workers appear to have borne the brunt of pandemic-related job losses (Ishibashi and Nakafuji 2020). The number of jobs lost by female workers is significantly higher than that of male workers. For example, $11.4 \%$ of female workers lost their jobs between December 2019 and August 2020, compared to $0.8 \%$ of male workers during the same period (Statistics Bureau of Japan 2020). This may have contributed to a reported recent rise in suicide among women. According to an August 2020 report on suicide by Japan's National Police Agency, the number of women who committed suicide rose by $51 \%$ between April 2020 and August 2020, from 442 to 669 , whereas the number of men committing suicide rose by $17 \%$ (National Police Agency 2020). The WHO needs to recognize such nation-specific inequalities as crucial for public health policies.

\section{The Transformation of the Japanese Welfare System and Challenges to Public Health}

Some observers have highlighted that during the initial stages of the COVID-19 pandemic Japan handled the coronavirus relatively well, maintaining 
a low number of infections and deaths in comparison to other countries. It did this despite being a densely populated country with a large elderly population (Iwasaki and Grubaugh 2020; Tashiro and Shaw 2020). In seeking to identify reasons for this relative success, commentators have pointed to Japan's culture, its medical and healthcare systems, the level of sanitation, citizens' behaviour, and the 'cluster approach' used (Tashiro and Shaw $2020,3)$.

However, it is not universally agreed that Japan has handled the pandemic entirely effectively, or that it has done so for these reasons. Crump and Tanimoto, for instance, have argued that Japan's situation worsened due to a mismanagement of the pandemic, lack of adequate personal protection equipment, and incompetence among hospital personnel (2020, 2). Similarly, An and Tang argue that Japan has mismanaged the pandemic, highlighting the country's lack of pre-established institutional infrastructure, the lack of legal means to impose substantive penalties, and its limited testing capacity in comparison to other East Asian polities (2020, 795-797). In contributing to this debate, this chapter leans towards the more critical interpretations, but in doing so it seeks to draw attention to the declining quality of welfare provision in Japan, arguing that this has been a decisive factor in explaining how the pandemic has been managed.

The Japanese welfare system introduced a universal medical insurance system in 1961. There was a stable labour market during the 196os, 1970s, and 1980 s. This was characterized by high levels of long-term employment (especially among men) and meant that Japan witnessed an increasing number of workers and increasing insurance contributions. This enabled the state to create a stable welfare system, including a well-functioning public health system. Migrant workers are also covered in this public health system. However, from the 1990s onwards, the neoliberalization of Japan's socioeconomic institutions has progressed steadily. This has been accompanied by a greater emphasis upon individual responsibility for health, including through the privatization (or partial privatization) of health, medical, and elderly care. The government raised insurance premiums from $20 \%$ to $30 \%$ in 2002. In 2011, it reduced the breadth of insurance coverage as part of a gradual increase in the privatization of public hospitals (Ogasawara 2018, 127). Moreover, since the bursting of Japan's so-called 'bubble economy' in 1991, it has experienced low economic growth and economic recessions. This has had a knock-on effect, posing problems for those who have difficulties paying, or are unable to pay, insurance contributions.

As a result, the number of people who are covered by the health insurance scheme has declined from $126,907,000$ people in 2010 , to $125,877,000$ 
persons in 2017 (MHLW 2018). In particular, there has been a significant decline in the number of people who are covered by the national health insurance, which also tends to cover non-regular workers. The number of people covered by this has fallen from $38,769,000$ people in 2010 to $31,475,000$ people in 2017 (MHLW 2018). This is also closely related to the increased number of non-regular workers in the labour market in Japan because the monthly contribution for national health insurance can be a heavy burden for people with low monthly incomes, taking nearly $20 \%$ of their wages (Sato 2014). The rising numbers of non-regular workers, including migrant workers who receive lower wages, face difficulties in paying their health insurance contributions. Moreover, according to Kin (2015), many employers have gradually shifted to non-regular workers who work for shorter hours. This way, employers can avoid paying the costly employers' contributions towards the health insurance of their employees. This trend for increasing non-regular employment will translate into public health deficiencies. During the COVID-19 pandemic, these risks have become more visible.

As part of the state of emergency introduced in Japan in early 2020, the government announced that it would provide 100,000 yen (or around US\$ 920) for every person in the country, including migrant workers and foreign students. However, this money has only been made available for those who had their address registered with their municipal government (Tokyo Shimbum 2020a; 2020b). This stipulation has meant that the government has effectively denied access to financial support for those most vulnerable, especially the homeless. In Japan, support for homeless people has been left to voluntary citizens' groups, reflecting the inadequate nature of public health provision for the homeless (Inaba 2014).

As this chapter has argued, the WHO's one-size-fits-all approach to giving advice risks being ineffective. For example, in spite of the pandemic the Japanese government has decided to continue cuts to the 'public assistance system' (seikatsu hogo seido) that have been ongoing since 2018. This public assistance system guarantees the minimum standard of living for those who have difficulties in making a living. This system provides financial support to enable people to have minimum living expenses (Ministry of Health, Labour and Welfare 2021). The next round of cuts has been announced for October 2020, despite the clear risks to public health these reductions will bring about during the pandemic (Kyodo 2020). The effect will be that $67 \%$ of households who receive the benefits will experience a reduction in financial support, which will worsen accessibility to medical care for those on benefits. 
While foreign residents with permanent residency or a settlement visa are also covered by this benefit scheme, it excludes migrant workers who are only permitted to live in Japan for a fixed term. As such, the availability of these benefits is neither sufficient nor comprehensive, something which further endangers impoverished households that are already vulnerable during public health crises such as the COVID-19 pandemic. In particular, migrant workers who have lost their jobs during the COVID-19 pandemic, and who are not entitled to these benefits, can suffer significantly as a result of their income loss.

Obstacles also exist for those who are entitled to access public health schemes. A number of companies - known as 'black companies' (burakku kigyō) - have a practice of registering employees as self-employed in order to deprive workers of their rights to minimum wage entitlements, overtime payments, the national insurance scheme, health insurance contributions, and medical care. Many migrant workers tend to suffer from this kind of exclusion, even though they are entitled to health insurance. This is compounded by the fact that workers on low pay and with insecure employment contracts have already faced considerable obstacles since before the pandemic began.

\section{Conclusion}

The guidance that has been issued by the WHO represents an important step in making public health recommendations for national governments. A key limitation of this guidance, however, is its scope. The WHO does not address nation-specific socio-economic institutions that have a large impact on public health. This chapter suggests that, in the context of Japan, we have to consider the effects of the ongoing neoliberal reforms across Japan's labour market and public health system. Japan has maintained a relatively low rate of infection, especially in comparison to Western Europe and the United States. However, more adequate employment protections and a comprehensive insurance system would have led to more effective management of the pandemic and long-term maintenance of public health. As the risk of infection has continued into 2021, a rise in unemployment and the fact that a substantial portion of the working population remains in low paid jobs hamper measures to secure public health. As this chapter has shown, the labour market, welfare provision, and public health are mutually dependent upon each other. Social inequality is a public health matter. 


\section{References}

An, Brian Y., and Tang Shui-Yan. 2020. 'Lessons from COVID-19 Responses in East Asia: Institutional Infrastructure and Enduring Policy Instruments.' American Review of Public Administration vol. 50, no. 6-7: 790-80o. https://doi. org/10.1177\%2Fo275074020943707.

Crump, Andy, and Tanimoto Tetsuya. 2020. ‘Covid-19:Japan's Success despite Inept Bureaucracy and Incompetence.' QJM: Monthly Journal of the Association of Physicians vol. 113, no. 7: 455-456. https://doi.org/10.1093/qjmed/hcaa181.

Hernández-Álvarez, Mario, Juan Carlos Eslava-Castañeda, Liliana Henao-Kaffure, José Orozco-Díaz, and Luis Edgar Parra-Salas. 2020. 'Universal Health Coverage and Capital Accumulation: A Relationship Unveiled by the Critical Political Economy Approach.' International Journal of Public Health vol. 65: 995-1001. https://doi.org/10.1007/s00038-020-01437-9.

Hunter, Benjamin M., and Susan F. Murray. 2019. 'Deconstructing the Financialization of Healthcare.' Development and Change vol. 50, no. 5: 1263-1287. https:// doi.org/10.1111/dech.12517.

Imano, Koichirō. 2020. 'Seiki/hiseiki rōdō' [Regular/Non-regular Work].' Nihon Rōdō Kenkyū Zasshi vol. 717: 14-17. https://www.jil.go.jp/institute/zassi/backnumber/2020/04/pdf/o14-017.pdf.

Inaba, T. (2014) Seikatsu Hogo kara Kangaeru [Think from Public Assistance]. Tokyo: Iwanami Shinsyo.

Ishibashi, Mari, and Nakafuji Rei. 2020. 'Women Bear Brunt of Japan's Pandemic Job Losses.' Nikkei Asia, 7 September. Accessed ${ }_{15}$ February 2021. https://asia.nikkei. com/Spotlight/Datawatch/Women-bear-brunt-of-Japan-s-pandemic-job-losses.

Iwasaki, Akiko, and Nathan D. Grubaugh. 2020. 'Why Does Japan Have so Few Cases of COVID-19?' EMBO Molecular Medicine vol. 12, no. 5: e12481. https://doi. org/10.15252/emmm.202012481.

'Kanzen shitsugyōsha, yuruyakani zōka: gogatsu no kyūgyōsha nao 423-man-nin [The Number of Unemployed is Gradually Increasing: The Number of Workers who are Absent during the Corona-period still Remains 4.23 Million People].' Nihon Keizai Shimbum, 30 June. Accessed 15 February 202. https://www.nikkei. com/article/DGXMZO6o958420QoA630C2EE80oo/.

Kin, Meichu. 2015. 'Hiseikikoyō zōkano yō'inn toshite no shakai hokenryō jigyōnushi futan no kanōsei [The Potential Social Insurance Contribution of Employers as a Cause of the Increased Number of Non-regular Workers].' Nihon Rōdō Kenkyū Zasshi vol. 659 (June): 27-46. https://www.jil.go.jp/institute/zassi/ backnumber/2015/06/pdf/o27-046.pdf.

Kyodo. 2020. ' $67 \%$ setai no seikatsu hogohi, gengaku e [67\% of the Recipient Households Face Reduction of Livelihood Protection Benefits].22o2o. Kyodo, 
2 September. Accessed 15 February 2021. https://this.kiji.is/6738269616018729 $93 ? \mathrm{c}=39546741839462401$.

Ministry of Health, Labour and Welfare (MHLW). 2018. 'Shakai-hoken dai-issho iryō hoken [Social Insurance, Chapter 1 Health Insurance].' Figure 5-1. Accessed 15 February 2021. https://www.mhlw.go.jp/toukei/youran/indexyk_5_1.html.

- 2020. 'Roudouryoku chōsa 2020-nen 11-gatsu kekka [Labour Force Survey November 2020 Report].' Accessed 15 February 2021. https://www.stat.go.jp/ data/roudou/sokuhou/tsuki/index.html.

—. 2021. 'Seikatsu hogo seido [Public Assistance System].' Accessed 15 February 2021. https://www.mhlw.go.jp/stf/seisakunitsuite/bunya/hukushi_kaigo/seikatsuhogo/ seikatuhogo/index.html.

National Police Agency. 2020. 'Reiwa 2-nen no jisatushasū ni tsuite [2020 Monthly Number of Suicides].' Accessed 15 February 2021. https://www.npa.go.jp/news/ release/2020/20200907001.html.

NHK. 2020. "WHO ha kōshū eisei yori seiji o yūsen" beikokumushō ga kenshō no kangae ["WHO Prioritized Politics over Public Health": The Department of State of the US Considers Verification].' NHKNews Web, 11 April. Accessed 15 February 2021. https://www3.nhk.or.jp/news/html/20200411/k10012381681000.html.

Ogasawara, Nobumi. 2018. 'Shinjiyūshugiteki iryō kaikaku ni okeru Kankoku to Nihon no hikaku kenkyū [Comparison between South Korea and Japan on Neoliberal Medical Care Reform].' Iryō Fukushi Seisaku Kenkyū vol 2, no. 1: 113-136. https://ci.nii.ac.jp/naid/130007623126/.

Satō, Shigeru. 2014. 'Shakai hoshō de kaette mazushiku naru!? [Social Insurance Scheme impoverishing us more!?]' imidas, 28 December. Accessed 15 February 2021. https://imidas.jp/jijikaitai/f-40-109-14-11-g554.

Sell, Susan K. and Owain D. Williams. 2020. 'Health under Capitalism: A Global Political Economy of Structural Pathogenesis.' Review of International Political Economy vol. 27, no. 1: 1-25. https://doi.org/10.1080/og692290.2019.1659842.

Shibata, Saori. 2020. Contesting Precarity: The Rise of Nonregular Workers and the New Policy Dissensus in Japan. Ithaca, New York: Cornell University Press.

Tashiro, Ai, and Rajib Shaw. 2020. 'COVID-19 Pandemic Response in Japan: What is Behind the Initial Flattening of the Curve?' Sustainability vol. 12, no. 13:5250. https://doi.org/10.339o/su12135250.

The Japan Times. 2020. 'Over 50,00o Workers in Japan Dismissed Due to Pandemic.' 2 September. Accessed 15 February 2021. https://www.japantimes. co.jp/news/2020/o9/o2/business/economy-business/5000o-dismissed-japanpandemic/.

Tokyo Shinbum. 2020a. 'Houmuresuheno jyuumanenkyuufukin, kosekikatsuyou mitomezu: shibuyaku no teiann ni soumusyou "jyuumin touroku de" [Homeless Are Not Allowed to Use their Family Registration to Apply for 100,000 Yen 
Allowance: Ministry of Communication and International Affairs Insist on 'residency Registration" to Shibuya ward head's suggestion]'. Tokyo Web, 18 June. Accessed 1 January 2021. https://www.tokyo-np.co.jp/article/36339

—. 202ob. 'Hōmuresu e no 10-man-en kyūfukin, koseki katsuyō mitomezu: Shibuyaku no teian ni Sōmushō "jūmin tōroku de" [Homeless People not Allowed to use Family Registration to Apply for 100,000 yen Allowance: Ministry of Communication and International Affairs insists on 'Residency Registration' to Shibuya Ward Suggestion].' Tokyo Shinbum, 18 June. Accessed 15 February 2021. https://www.tokyo-np.co.jp/article/36339.

Tomokuni, Hisashi. 2020. “'Chokin kuzushiteiru ga...” daikigyō no hiseiki kuni no shien okizari ["I have been using my savings..." Non-regular Workers at Large Corporations Left Behind from Government Support].' Nishinihon Shimbum, 23 September. Accessed 15 February 2021. https://www.nishinippon.co.jp/ item $/ \mathrm{n} / 646635 /$.

Toyo Keizai Online. 2020. "Korona shitsugyō" reikoku ni kirisuterareru hitobito no sakebi [People's Voice Against the Cruel Cases of "Coronavirus Dismissals"].' livedoor NEWS, 22 June. Accessed 15 February 2021. https://news.livedoor.com/ article/detail/18453437/.

World Health Organization (WHO). 2020a. 'Shingata korona uirusu kansenshō: kankeisha muke tokusetsu peiji [COVID-19: Special Page for Interested Parties].' 21 August. https://extranet.who.int/kobe_centre/ja/covid/covid-technical.

—. 2020b. 'Covid-19 and gender.' Advocacy Brief, 14 May. https://extranet.who.int/ kobe_centre/sites/default/files/G43_20200514_JA_Gender.pdf.

\section{About the Author}

Saori SHIBATA, PhD, is an Assistant Professor at Leiden University. Her research focuses on Japan's political economy, including the changing nature of work, the digital economy, and how Japan's model of capitalism is transforming. This draws on institutionalist approaches to capitalism and critical political economy. She has published on these topics in journals such as New Political Economy and British Journal of Political Science. She is the author of Contesting Precarity in Japan: The Rise of Nonregular Workers and the New Policy Dissensus (Cornell University Press, 2020). 



\title{
15 Indonesia's Response to Global Recommendations on Labour
}

\author{
Migration during a Pandemic: Muddling through Priorities \\ and Needs
}

Sylvia YAZID

\begin{abstract}
Policies made to address the global COVID-19 pandemic have significantly affected people's mobility between countries. For migrant labour sending countries, such as Indonesia, the government has had to deal with the pandemic domestically while simultaneously managing the social and economic impacts and safety of citizens abroad or in transit. This chapter assesses the Indonesian government's policy responses related to labour migration. It shows that they have been in line with the recommendations made by relevant international organizations, such as the International Labour Organization (ILO), but that such recommendations often fail to address nation-specific issues. In doing so, this chapter contributes to the understanding of transnational migrant labour governance in Asia.
\end{abstract}

Keywords: Indonesia, labour migration, International Labour Organization, global health governance, labour mobility, COVID-19

\section{Introduction}

COVID-19, with its rapid transmission rate, has required countries to take strong emergency actions to limit its impact. While SARS and MERS were relatively containable, COVID-19 has seen governments implementing policies specifically targeting highly affected areas and has forced countries

\footnotetext{
Van der Veere, Anoma P., Florian Schneider, and Catherine Yuk-ping Lo (eds), Public Health in Asia during the COVID-19 Pandemic: Global Health Governance, Migrant Labour, and International Health Crises. Amsterdam, Amsterdam University Press 2022 DOI: 10.5117/9789463720977_CH15
} 
to temporarily close their borders. The pandemic has caused stagnant economic growth, pushing different countries into recessions.

A striking feature of the pandemic has been the effect it has had on the mobility of migrant workers. It has disrupted workers' mobility as countries have implemented protectionist policies such as border and travel restrictions, as well as entry bans for migrants from certain countries. For countries such as Indonesia that send many workers abroad (referred to as 'sending countries'), this has led to postponed departures and the unplanned return of migrant workers. For example, Indonesia's National Board of the Placement and Protection of Indonesian Overseas Workers (BP2MI), reported in early 2020 that 37,379 Indonesian migrant workers had postponed their departure, and 129,202 workers were repatriated (BP2MI 2020). As a result of this, concerns have surfaced about the protection of the rights of these workers. If restrictions continue, labour migration might go underground, with migrant workers departing through unofficial channels.

When it comes to migration governance in Southeast Asia, nations already have limited capabilities (Kneebone 2010, 392), signifying the importance of external parties such as international organizations. Epidemics and pandemics have further highlighted how global health governance requires rigorous coordination between various stakeholders at different levels and the commitment of global, national, and local authorities. This chapter examines Indonesia's policy responses to the pandemic, assessing whether they are in line with recommendations made by international organizations such as the International Labour Organization (ILO). While the COVID-19 pandemic requires collaborative actions led by global authorities, criticism concerning the performance of international organizations and the commitments of member countries grew during the pandemic. This chapter shows how attempts at global governance should take into account the specific characteristics and needs of each country, in this case of Indonesia.

\section{Method}

The 1990 International Convention on the Protection of the Rights of All Migrant Workers and Members of Their Families recognizes the need for states to ensure the protection of the rights of migrant workers (Nanda 1993, 161-177). However, the signing and ratification of this convention do not automatically guarantee that these rights will be fulfilled. Two decades later, there remains a gap between the global recommendations and countries' specific needs for protection of migrants' rights. 
This chapter analyses whether, in the case of Indonesia's response to the COVID-19 pandemic, these measures are actually closing the gap. It does so by combining a literature study with interviews to analyse Indonesia's response to the pandemic and its conformity to ILO recommendations regarding labour migration during a pandemic. The research relies on publicly available data and information gathered from interviews. The interviews were with Judha Nugraha, Director of Protection for Indonesian Citizen and Legal Entities of the Ministry of Foreign Affairs of Indonesia, Brian Sriprahastuti, Senior Advisor at the Executive Office of the President of Republic of Indonesia, and Anis Hidayah, Head of Migrant Study Center of Migrant CARE, all of whom kindly agreed to be identified for the purpose of this study.

\section{Protecting Migrant Workers during the Pandemic: ILO Recommendations}

The ILO has released several policy recommendations regarding migrant workers and the fulfilment of their rights during a pandemic. This chapter refers to the earlier policy brief titled Protecting Migrant Workers during the COVID-19 Pandemic (ILO 2020). It was released in April 2020 and highlights three key areas of action: 'migrant workers' inclusion in national COVID-19 responses, bilateral cooperation between countries of origin and destination, and social dialogue and full involvement of employers' and workers' organizations in the development of COVID-19 responses' (ibid.). For the purpose of analysing Indonesia's responses, this chapter focuses on the first area of action, consisting of six recommendations. Although these recommendations may seem directed toward countries receiving migrants ('receiving countries'), they are actually quite general and are also of concern for sending countries.

The ILO's recommendations on the inclusion of migrant workers in national COVID-19 responses suggest different kinds of support for these workers. The first kind of support is economic. The ILO encourages countries to provide financial support for migrant workers, based on reliable data. It also stresses accessible healthcare and social protection for migrant workers of all statuses. Additionally, making sure that these migrant workers are well-informed regarding health and safety information is considered crucial. Alongside this, the ILO also recommends that countries provide workers with access to essential migration services. This is to ensure that migrant workers do not fall into irregular status. The ILO also states that countries should 
provide appropriate communal accommodation and quarantine areas, so that migrant workers are free from hazards in their communal or worksite housing. Finally, the ILO recommends that governments provide migrant workers with legal counsel to prevent them from being undocumented or irregular.

The ILO made these six recommendations at the beginning of the COVID-19 pandemic, giving them to governments to address the main challenges that migrant workers face during the pandemic. The next section looks into Indonesia's policy responses to the pandemic and identifies whether these responses fit into the framework that the ILO set out. ${ }^{1}$

\section{Protecting Migrant Workers during the Pandemic: Indonesia's Policy Initiatives}

Indonesia confirmed its first positive case of COVID-19 on 2 March 2020. Since then, the government has taken various steps to address the pandemic at the national, provincial, city/municipality, and village levels. There have also been attempts to coordinate between levels and across neighbouring areas. Indonesia's two main policies related to labour migration are: the Ministry of Manpower Decree No. 151 of 2020 concerning the Temporary Cessation of Placement of Indonesian Migrant Workers (PMI), and the Ministry of Manpower Decree No. 294 of 2020 concerning the Implementation of Placement of Indonesian Migrant Workers during the New Normal Adaptation.

With the first policy, Indonesia sought to slow the spread of COVID-19 by temporarily stopping the placement of Indonesian migrant workers. Indonesia's National Board of the Placement and Protection of Indonesian Overseas Workers, or $\mathrm{BP}_{2} \mathrm{MI}^{2}{ }^{2}$ coordinated with a number of related ministries in supporting migrant workers who were delayed in departure, stuck in the country of placement, or who had to return to Indonesia. The enactment of this regulation also temporarily halted the departure of those who wished to leave for placement. However, this was not a full-fledged moratorium or repatriation of Indonesian migrant workers abroad. After

1 The discussion in this chapter has been based on the situation in Indonesia, as well as the information and data that were produced, during the early stages of the pandemic. This situation and information determined many of the related policies made at later stages.

2 Indonesia's National Board of the Placement and Protection of Indonesian Overseas Workers (Badan Pelindungan Pekerja Migran Indonesia), or BP2MI, is a non-departmental government agency that oversees the implementation of policies in the placement and protection of Indonesian workers abroad. 
the regulation was put in place, those with valid work-visas have still been able to depart if their country of destination allowed arrivals. Those in the country of placement have still been able to reside there in accordance with their work contract (Kemnaker RI 2020a).

To order a complete halt of the placement of migrant workers would have been a difficult choice for Indonesia to take amidst the economic slowdown faced during the pandemic. Therefore, five months after the temporary halt, the placement of migrant workers restarted again, with the sending of migrant workers to thirteen countries. The government adopted this as a new policy, the Minister of Manpower Decree No. 294 concerning the Implementation of Placement of Indonesian Migrant Workers, that aimed to regenerate remittances from abroad during what was labelled as a 'New Normal Adaptation'.

The Indonesian government has been trying to balance protecting public health and safeguarding the economy. This balancing was discussed in several of the interviews conducted for this chapter. According to Sriprahastuti, the government's balancing act explains President Joko Widodo's use of an approach that shifted between acceleration and braking. ${ }^{3}$ The balancing act was also discussed by Nugraha, who posited that migration is not only about economic development, but also about human development. ${ }^{4}$ However, critics also argued that this approach has not prioritized migrant workers. In her interview, for example, Hidayah argued that the current policy was aimed at generating income for the country rather than protecting the welfare of migrant workers. ${ }^{5}$ She warned of the possible increase of migration when the pandemic eventually eases and therefore insisted on the preparation of a concrete welfare protection protocol.

Through the enactment of the aforementioned policies, Indonesia has shown its concerns about economic and human development, social protection, healthcare and safety, information, and documentation schemes. It is apparent that while the safety and health of migrant workers have been considered important, the (re)sending of migrant workers has also been made a part of Indonesia's economic recovery strategy.

In terms of economic and human development policies, Indonesia has made efforts to refocus activities and reallocate budgets to accelerate support for migrant workers affected by COVID-19 (BP2MI 2020). Consider, for example, the distribution of Pre-Employment Cards (Kartu Prakerja) to job-seekers, 
including workers who were laid off due to the pandemic. The holders of these cards are eligible to access skill development training and receive paid post-training incentives. As was explained by Nugraha, this initiative is intended to include migrant workers who lost their jobs. ${ }^{6}$ Therefore, the Ministry of Manpower (MoM) collected data on prospective migrant workers (PMW) and current migrant workers (CMW). It has submitted this data to the Coordinating Ministry for Economic Affairs, so that these migrant workers can be registered for the Pre-Employment Card programme. The National Board of the Placement and Protection of Indonesian Overseas Workers (BP2MI) has also coordinated with local offices of the Ministry of Manpower and the Indonesian Migrant Worker Placement Company ( $\mathrm{P}_{3} \mathrm{MI}$ ) to assist in the registration process. This data is also being used for the allocation of the work opportunity expansion programme that aims to encourage labour productivity (BP2MI 2020). Through the programme, it is expected that current and prospective migrant workers will improve their skills and boost productivity, which is hoped to reduce the number of unemployed.

In order to provide social protection for migrant workers, $\mathrm{BP}_{2} \mathrm{MI}$ has made suggestions to the Employment Social Security Administration (BPJS Ketenagakerjaan). It has made suggestions specifically regarding the filing of benefit claims for current and prospective migrant workers, as well as for utilizing the Social and Environmental Responsibility (TJSL) programme of BPJS Ketenagakerjaan as an effort to ensure the welfare of Indonesian migrant workers (BP2MI 2020). It can be said that by these means, current and prospective migrant workers have been included in the national policies aimed at addressing pandemic-triggered economic issues. This general approach is confirmed by Sriprahastuti, who explained how economic recovery policies such as cash assistance for small and medium enterprises have been given to everyone, including migrant workers. ${ }^{7}$

To ensure access to health services during this pandemic, in March 2020 the Indonesian Task Force for COVID-19 (Gugus Tugas Percepatan Penanganan COVID-19) issued the Guidelines for Rapid Medical Response and Public Health Aspects of COVID-19. During the early months of the pandemic, when the repatriation wave was high, the government made efforts to ensure the safety of returning migrant workers by imposing measures such as quarantines and provision of facilities, measures in which migrant workers received priority. For example, an emergency hospital was established on Galang Island that specifically prioritized the care of infected migrant

6 Judha Nugraha, interview by author.

7 Brian Sriprihastuti, interview by author. 
workers. According to Sriprahastuti, at the beginning of the pandemic when Indonesia was still considered to be safe, more specific attention was given to migrant workers. This specific attention given to migrant workers was based on the idea that they were coming from affected countries. ${ }^{8}$

As the pandemic has continued, the greater attention given to migrant workers has decreased. The direction of efforts has been reversed, from dealing with migrant workers coming back to Indonesia to facilitating their employment abroad. As Nugraha pointed out, the government is now trying to make sure that the immigration services for migrant workers follow the COVID-19 protocols of the destination country both upon their departure and arrival. ${ }^{9}$ Therefore, specific measures regarding health services and social protection have become associated with the mobility of migrant workers. However, once they receive official clearance for entry, workers are again considered part of their local community and are not specifically targeted as migrant workers in official policy. While this approach can be considered fair, migrant workers' advocates have argued for the specific identification and treatment of migrant workers while they are at home in Indonesia. They claim this is necessary because these migrant workers do not face exactly the same problems as the local unemployed.

In ensuring accessible information, the government has made attempts to increase the effectiveness of communication on health and safety with workers and related organizations. $\mathrm{BP}_{2} \mathrm{MI}$ and the MoM have coordinated with the Representatives of the Republic of Indonesia (KBRI) in migrant workers' countries of placement to provide for logistical needs and repatriation. A 24-hours complaint service for Indonesian migrant workers abroad has been established (Kemnaker RI 2020a). To help overseas workers manage the risks of COVID-19, they have provided protective equipment (such as masks and sanitizers) and risk assessment for individuals with higher risks of being infected (WHO 2020a).

In addition, the government has communicated with employers in placement countries to enable workers to get more flexibility in working hours, while still receiving wages. The government has coordinated with figures in the placement countries to ensure the implementation of the WHO COVID-19 risk management protocols both at work and in the workers' housing facilities. Efforts have also been made to provide information through organizations, public figures, social media platforms, and various other media (Kemnaker RI 2020a). 
Nugraha stated that, although efforts have been made to ensure the dissemination of complete and accurate information, there is still room for improvement, such as extending the coverage of public awareness campaigns to villages. ${ }^{10}$ Hidayah also suggested that the information available has tended to be generic, leaving workers to struggle with more specific conditions that are not included in this available information. ${ }^{11}$ With the reopening of Indonesian borders for workers, the availability of comprehensive information is crucial.

The MoM and the KBRI have taken measures in the placement countries of migrant workers to ensure the proper documentation of Indonesian migrant workers. At the beginning of the pandemic, these focused on returning migrant workers. As the pandemic continued, the measures then sought to ensure the sustainability of the placement programme for prospective workers after the COVID-19 pandemic ends, to synchronize labour migration policy with the policies of the country of placement, and to make sure that all workers are documented and receive training according to existing procedures (Kemnaker RI 202ob).

In the 'new normal' adaptation period which Indonesia has moved into now, the sending of migrant workers abroad is being resumed. The MoM has issued a policy directive to regulate the verification and legalization of Request Letters for migrant workers that overseas employers provide. It has also issued a directive to regulate the quota approvals submitted by employers or business partners through the KBRI or the Indonesian Economic and Trade Office (IETO) abroad. Before departure, the MoM will verify and legalize the Requests for Indonesian Migrant Workers and the quota approvals that employers have submitted (Kemnaker RI 2020b).

The employer and/or the government of the placement country are expected to take responsibility for matters such as workplace safety, working conditions, the cost of implementing the health protocols in the country, and other costs incurred if a worker is infected while abroad. They are also expected to provide a guarantee for the well-being of Indonesian migrant workers. Also, at the time of arrival in their country of placement, workers are required to report their arrival to the KBRI, either offline or online through the SafeTravel application and the Portal Peduli WNI. The Portal Peduli WNI is a digital platform which Indonesian citizens can use to report their own arrivals, transfers, and returns. 
These measures the Indonesian government has taken have been focused on repatriation and facilitating mobility. They are based on previously existing mechanisms, only now with the added health protocol and requirements that the WHO provided. Unfortunately, as Hidayah pointed out, some immigration services in Indonesian embassies have been disrupted as a result of the change to online services made necessary by COVID-19. This has resulted in administrative problems such as challenges to the collection of data about migrant workers' mobility. It has also meant disruption to some consular services. ${ }^{12}$ Moreover, as Nugraha stated, protection efforts depend on the procedural or non-procedural nature of workers' mobility, which may be influenced by other countries' policies. ${ }^{13}$

The government has taken steps to ensure the provision of healthy living conditions at communal or worksite housing. In Indonesia, it has made efforts to minimize the amount of communal living during the pandemic by sending home those waiting for departure and vacating shelters and the Overseas Training Centre (Balai Latihan Kerja Luar Negeri) (BP2MI 2020). However, the government has not been able to do so much to impact the communal living of Indonesian migrant workers overseas. In terms of communal living arrangements in the country of placement, the $\mathrm{BP}_{2} \mathrm{MI}$ and the MoM established the aforementioned 24-hours service for complaints of Indonesian labour migrants in placement countries. They also coordinated with relevant stakeholders to monitor the repatriation of prospective workers to their areas of origin ( $\left.\mathrm{BP}_{2} \mathrm{MI} 2020\right)$.

There have been no reports from migrant workers of serious legal issues resulting from the pandemic. So far, the legal process in place for these workers has been a continuation of what was already in place before the pandemic (Kurniati 2020). Nevertheless, to ensure access to legal remedies for all migrant workers, the MoM continues to monitor condition reports, placement country policies, handling efforts, and potential problems that may occur in fulfilling migrant workers' rights (Kemnaker RI 202ob). The MoM also coordinates with all relevant stakeholders to continue reporting, monitoring, and evaluating the placement of Indonesian migrant workers. In doing this, it focuses on matters such as complaint services, health conditions, numbers of prospective Indonesian migrant workers, and the current condition of the country of placement (Kemnaker RI 202ob). In short, efforts made to ensure access to legal remedies have been similar to pre-pandemic policies. 


\section{Migration Governance in Indonesia during the COVID-19 Pandemic: A Response Aligning with Global Recommendations?}

This outline of the situation regarding migrant workers during the early stages of pandemic, and the steps that the Indonesian government has taken on this issue, shows that the government policies and initiatives are essentially in line with the ILO's recommendations. The government's economic and social policies have included migrant workers as beneficiaries, treating them like other citizens of Indonesia. The government of Indonesia has made an effort to give migrant workers access to services and information. There have still been challenges in the implementation of these policies, however, some of which are the result of the need to balance the safety and health of the people and economic recovery. It is difficult to determine whether or not the policies the Indonesian government has taken were made based on the ILO's recommendations. This is particularly as the recommendations made by the ILO are not legally binding and their power depends on the willingness of governments to adopt them. Therefore, to establish correlation between Indonesia's national policies and the ILO's recommendations, the shape of Indonesia's pandemic response needs to be explored in relation to the role that has been played by international organizations during COVID-19.

According to Nugraha, the relevance of international organizations has increased during the COVID-19 pandemic. This is because countries frequently lacked the resources to address problems individually, particularly in terms of labour migration. ${ }^{14}$ Nugraha emphasized the importance of joint efforts through initiatives such as the Travel Corridor Arrangement (TCA). ${ }^{15}$ The TCA is a bilateral agreement between Indonesia and countries including the United Arab Emirates (UAE), South Korea, Malaysia, and Singapore. The agreement was made in order to boost economic relations through travel permits for business essentials and diplomatic visits. Nugraha said he was hopeful that this arrangement would soon be implemented multilaterally. ${ }^{16}$ The TCA is evidence of the way in which solutions so far have tended to be sought on a bilateral basis with the countries involved. Since recommendations from international organizations such as the ILO have been quite general, countries have tended to work out their own solutions and arrangements based on their own specific needs. 
Sriprahastuti argued that, in making health policy, the Indonesian government has acted in accordance with WHO recommendations. She said, for example, that Indonesia had followed the WHO guidelines in the activation of the initial emergency response. ${ }^{17}$ She claimed that Indonesia has adopted two out of the three WHO recommendations: prevention and response. Recovery is yet to be implemented, but social distancing and testing have been adopted. In general, practical and direct recommendations have been easier to adopt. However, there are complex factors that need to be considered. As a sending country, with a large population and approximately 135 entry points, Indonesia is currently facing two major emergencies: the handling of health matters, and the challenge of ensuring economic development. ${ }^{18}$

Nugraha explained how Indonesia has implemented the ILO recommendations with local adjustments based on domestic needs. ${ }^{19}$ The current challenge is establishing coordination between stakeholders. In this respect, Sriprihastuti argued that, if the policies it has put in place are to have their desired effect, Indonesia needs a more binding structure to ensure the enforcement of new regulations while also considering the economy. ${ }^{20}$ It is notable that the leadership of the task force responsible for the pandemic response in Indonesia has changed several times. It has moved from the President's Staff Office, to the Head of The National Agency for Disaster Countermeasure, and then finally to the Minister of State Owned Enterprises. This corresponds to a changing policy focus. As the pandemic has continued, the targets have shifted to economic recovery. This also indicates a change in how the issue is perceived, with it moving from being solely a health issue, to a health and economic issue.

Regarding the functioning of international organizations, however, Sriprahastuti also argued that more leadership is needed to improve global governance systems. She argued that the recommendations made by these organizations still treat the economy and health as separate which is detrimental for a comprehensive understanding of labour issues during a pandemic. Sriprihastuti described how, rather than the organizations leading the way, some countries have come up with their own innovations, to which the WHO then responded. On a similar note, Hidayah stated that the ILO's recommendations provided a necessary policy framework. However, whether these recommendations are known and understood by 
those making policy in Indonesia, and whether they are accommodated in national and local policies, remains unclear.

\section{Conclusion}

In managing the issues of Indonesian migrant workers, the government has taken several measures and initiatives to protect and ensure their welfare. These measures have been implemented through the enactment of the Ministerial Decrees No. 151 and No. 294. The government translated this decision into policies in economics and human development, social protection, healthcare and safety, information, and documentation. Meanwhile, on the global scale, the ILO has published policy recommendations for nations to implement in assuring the fulfilment of migrant workers' rights. This chapter has shown that, in general, the policies and programmes carried out in Indonesia have corresponded with the ILO recommendations. However, in the implementation of these policies, challenges prevail both domestically and internationally.

There are two key takeaways that can be drawn from Indonesia's case. First, issues concerning migrant workers during a pandemic should not be perceived only as issues faced by receiving countries. There are also problems when workers are forced to go back to their country of origin. This then requires policies from the sending countries' government. This government may consider the migrant workers returned from abroad as either a regular part of society, or as a particular group that requires specific policies. Second, the general solutions to handling the pandemic proposed by international organizations will eventually reach their limits. Each country has its own issues that require specific, localized solutions. Therefore, recommendations made by international organizations as part of an attempt at global governance should take into account the dynamic and specific characteristics and needs of each country.

\section{References}

Abdi, Alfian Putra. 2020. 'Kelompok Yang Terlupakan: TKI Yang Pulang Saat Pandemi.' Tirto.id, 28 June. Accessed 15 February 2021. https://tirto.id/ kelompok-yang-terlupakan-tki-yang-pulang-saat-pandemi-fLwu.

Badan Pelindungan Pekerja Migran Indonesia (BP2MI). 2020. 'Pelindungan Pekerja Migran Indonesia Pada Masa dan Pasca Pandemi Covid-19.' In Webinar hosted by Migrant CARE, 12 May. 
Gugus Tugas COVID-19. 2020. 'Pedoman Penanganan Cepat Medis dan Kesehatan Masyarakat COVID-19 di Indonesia.' June.

Hidayah, Anis. 2020. 'Mengubah Peta Jalan Perlindungan Buruh Migran pada Masa Pandemi.' In Webinar hosted by LPPM Universitas Trunojoyo Madura and Migrant CARE, 29 September.

International Labour Organization (ILO). 2020. 'Protecting Migrant Workers during the COVID-19 Pandemic.' 30 April. Accessed 15 February 2021. https:// www.ilo.org/global/topics/labour-migration/publications/WCMS_743268/ lang--en/index.htm.

Kementerian Ketenagakerjaan Republik Indonesia (Kemnaker RI). 2020a. 'Kebijakan Pemerintah Terkait Migrasi di Masa Pandemi COVID-19.' In Webinar hosted by Migrant CARE, 12 May.

—. 202ob. 'Keputusan Menteri Ketenagakerjaan Republik Indonesia Nomor 294 Tahun 2020 Tentang Pelaksanaan Penempatan Pekerja Migran Indonesia Pada Masa Adaptasi Kebiasaan Baru.'

Kneebone, Susan. 2010. 'The Governance of Labor Migration in Southeast Asia.' Global Governance vol. 16, no. 3: 383-396. http://www.jstor.org/stable/29764953. Kurniati, Pythag. 2020. '5 Fakta Parti Liyani, TKI Dari Nganjuk Yang Menang Atas Tuduhan Pencurian Bos Bandara Changi Singapura.' Kompas, 25 September. Accessed 15 February 2021. https://regional.kompas.com/ $\mathrm{read} / 2020 / 09 / 26 / 05400011 / 5$-fakta-parti-liyani-tki-dari-nganjuk-yang-menangatas-tuduhan-pencurian-bos.

Nanda, Ved P. 1993. 'The Protection of the Rights of Migrant Workers: Unfinished Business.' Asian and Pacific Migration Journal vol. 2, no. 2: 161-177. https://doi. org/10.1177/011719689300200204.

World Health Organization (WHO). 2020. 'Coronavirus Disease (COVID-19): Health and Safety in the Workplace.' Accessed 27 November 2020. https://www.who. int/news-room/q-a-detail/coronavirus-disease-covid-19-health-and-safety-inthe-workplace.

Yayboke, Erol. 2020. 'Five Ways COVID-19 is Changing Global Migration.' Center for Strategies \& International Studies, 25 March. Accessed 15 February 2021. https://www.csis.org/analysis/five-ways-covid-19-changing-global-migration.

\section{About the Author}

Sylvia YAZID is currently an Associate Professor at the International Relations Department of Parahyangan Catholic University, Indonesia. She wrote about how Indonesian NGOs have influenced Indonesia's domestic and foreign policies on migrant workers to obtain her $\mathrm{PhD}$ from Monash 
University, Australia. Following this, Sylvia has continued to work on the issue of labour migration policies. Recently she has expanded her research interests to include the issues of democratization and human rights both in domestic and international contexts. 